PHELIPPE TOLEDO PIRES DE OLIVEIRA

\title{
A TRANSAÇÃO EM MATÉRIA TRIBUTÁRIA
}

\author{
DISSERTAÇÃO DE MESTRADO \\ Orientador: Professor Doutor GERD WILLI ROTHMANN
}

FACULDADE DE DIREITO DA UNIVERSIDADE DE SÃO PAULO (USP) SÃo PAULO 
PHELIPPE TOLEDO PIRES DE OLIVEIRA

\section{A TRANSAÇÃO EM MATÉRIA TRIBUTÁRIA}

Dissertação de Mestrado apresentada à Faculdade de Direito da Universidade de São Paulo, Departamento de Direito Econômico e Financeiro, em nível de MESTRADO, sob a orientação do Professor Doutor GERD WILLI ROTHMANN.

FACULDADE DE DIREITO DA UNIVERSIDADE DE SÃO PAULO (USP)

SÃo PAULO

2013 


\title{
Phelippe Toledo Pires de Oliveira
}

\author{
A transação em matéria tributária
}

Dissertação submetida à banca examinadora em âmbito de Pós-Graduação da Faculdade de Direito da Universidade de São Paulo para obtenção do título de Mestre em Direito.

Área de concentração: Direito Econômico e Financeiro

Aprovado em:

Banca Examinadora:

Orientador: Professor Doutor Gerd Willi Rothmann

$2^{\circ}$ Examinador

$3^{\circ}$ Examinador 


\section{AGRADECIMENTOS}

Devo especial agradecimento ao Professor Doutor Gerd Willi Rothmann, exemplo de professor e de pessoa, que gentilmente me aceitou como seu orientando, depositando em mim sua confiança. Seu incentivo e orientações foram muito valiosos para esse trabalho.

Devo agradecimentos também aos Professores Dr. Paulo Celso Bergstrom Bonilha e Dr. Gustavo Justino de Oliveira, pelas sugestões no exame de qualificação, que ajudaram imensamente na elaboração e no aprimoramento de minha dissertação.

Agradeço ainda aos Professores Dr. Alcides Jorge Costa, Dr. André de Carvalho Ramos, Dr. Carlos Alberto Salles de Oliveira, Dr. Erasmo Valladão Azevedo e Novaes e França, Dr. Fernando Facury Scaff, Dr. Hermes Marcelo Huck, Dr. José Marício Conti, Dr. Luís Eduardo Schoueri e Dr. Wagner Menezes, com quem tive a oportunidade de cursar disciplinas no decorrer do curso de Pós-Graduação.

Gostaria de agradecer também à Faculdade de Direito da Universidade de São Paulo pela oportunidade de estudos e acolhimento. Agradeço, igualmente, ao Instituto Brasileiro de Direito Tributário (IBDT) e à Universidade de Paris I - Panthéon-Sorbonne, que contribuíram para a pesquisa bibliográfica deste trabalho.

Agradeço ainda à todos os colegas Procuradores da Fazenda Nacional que, de alguma forma, colaboraram para algumas das discussões que resultaram na elaboração deste trabalho. Em especial, agradeço ao Dr. José Levi Mello do Amaral Júnior, por discutir algumas das idéias esboçadas no presente trabalho.

Não poderia deixar de agradecer à minha família e aos amigos, que me apoiaram e compreenderam minha ausência em diversos momentos nos últimos meses, para que esta dissertação pudesse ser concluída.

Por fim, agradeço à minha amada esposa Diana Piatti de Barros Lobo, não somente pela revisão e pelas sugestões para o aperfeiçoamento deste trabalho, como também pela sua compreensão nos momentos de angústia intelectual. 
A meus pais, Adalberto e Vera, por permitirem minha educação e pelo amor incondicional.

A meu irmão Breno, exemplo de determinação e perseverança.

A minha amada esposa e companheira, Diana, pelo apoio e compreensão em todos os momentos. 


\section{RESUMO}

OLIVEIRA, P. T. P. A transação em matéria tributária. 2013. Dissertação (Mestrado) Faculdade de Direito, Universidade de São Paulo, 2013.

A transação em matéria tributária insere-se no contexto das transformações ocorridas no Direito Tributário. Decorre da busca por uma maior legitimidade social do tributo, pela eficiência na gestão administrativo-tributária e por um estreitamento das relações físcocontribuinte. O estudo faz um breve apanhado dos instrumentos de "negociabilidade", onde há participação dos contribuintes. Analisa a experiência estrangeira em matéria de transação tributária. Embora, no ordenamento brasileiro, a questão possa encontrar obstáculo na impossibilidade de transação pela Administração Pública, afasta-se preliminarmente esse dogma com a demonstração de que a transação conforma-se com os princípios norteadores do Direito Público (legalidade, indisponibilidade do interesse público, discricionariedade, proporcionalidade, eficiência, etc). Após uma análise crítica dos artigos 156, III e 171 do CTN, que tratam da transação como forma de extinção do crédito tributário, afastam-se os possíveis conflitos da transação tributária em relação aos princípios e dispositivos de ordem tributária (legalidade tributária, obrigatoriedade do lançamento e cobrança do crédito tributário, vedação à renúncia de receitas e igualdade tributária). Examinam-se exemplos de transação tributária na legislação de alguns Estados da federação e nos Juizados Especiais Federais. O estudo se volta então à análise do PL n ${ }^{\circ}$ 5.082/2009, que visa a regulamentar o instituto da transação tributária no âmbito federal. Esse projeto constitui uma alternativa viável para a redução da litigiosidade e desobstrução do Poder Judiciário. Seu exame aprofundado permite concluir que o PL no 5.082/2009 estaria em consonância com o ordenamento pátrio e com o atual contexto do Direito Tributário, mas que deveria haver alguns reparos em seus dispositivos.

Palavras-chave: Transação. Direito Tributário. Cooperação fisco-contribuinte. 


\begin{abstract}
OLIVEIRA, P. T. P. Tax agreements. 2013. Dissertação (Mestrado) - Faculdade de Direito, Universidade de São Paulo, 2013.
\end{abstract}

The tax agreements fall within the context of the recent developments in Tax law. It follows the quest for greater legitimacy of taxes, an efficient tax administration and an enhanced relationship between tax authorities and taxpayers. This study gives a brief overview of the types of agreements that can be entered by taxpayers with the tax administration. It then analyzes other countries' experiences with regard to agreements on tax matters. Although the simple possibility of a public entity entering into an agreement regarding "public interest" can apparently find barriers in our system, this dogma is put aside once demonstrated that such agreements are in accordance with principles of Public Law (rule of law, unavailability of public interest, discretion, proportionality, efficiency, etc). After analyzing articles 156, III and 171 of the Brazilian Tax Code, which deals with tax agreements as a way to put an end to a tax liability, we conclude that those agreements do not violate the rule of law, the mandatory collection of tax credits, the prohibition of waiving tax revenues nor tax equality. The study also examines examples of tax agreements according to state legislation as well as to Federal Small-claims courts' legislation. Then, the study analyses the bill $\mathrm{n}^{\mathrm{o}} 5.082 / 2009$, which aims to regulate tax agreements at the federal level. This bill is an alternative for reducing litigation between taxpayers and the tax administration. After reflection, it seems that the proposed bill is in accordance with Brazilian law as well as with the present context of Tax Law, but needs amendments.

Keywords: Tax Agreements. Tax Law. Enhanced relationship. 


\section{RÉSUMÉ}

OLIVEIRA, P. T. P. La transaction fiscale. 2013. Dissertação (Mestrado) - Faculdade de Direito, Universidade de São Paulo, 2013.

La transaction fiscale se trouve dans le contexte des changements intervenus dans le Droit fiscal. Découle de la recherche d'une plus grande légitimité sociale de l'impôt, d'une administration fiscale efficace et d'une relation plus étroite entre le fisc et le contribuable. L'étude donne un bref aperçu des instruments de "négociation" en matière fiscale qui peuvent être conclus entre l'administration et les contribuables. Il analyse des expériences étrangères dans le domaine de la transaction fiscale. Bien que la question peut apparemment trouver des obstacles dans le Droit brésilien, notamment à cause de la prétendue impossibilité pour l'administration de conclure une transaction, cet obstacle est écarté en démontrant que la transaction est conforme aux principes directeurs du Droit public (légalité, indisponibilité de l'intérêt public, proportionnalité, efficacité, etc). Après une analyse critique des articles 156, 171 et III du Códe Général des Impôts brésilien, qui prévoit la transaction comme une forme du contribuable se libérer de sa dette fiscale, on écarte des possibles conflits entre la transaction fiscale et les principes et les dispositions en matière fiscale (légalité de l'impôt, notification et recouvrement obligatoires, interdiction de renoncer à des recettes fiscales et égalité devant l'impôt). L'étude examine également des exemples de transaction fiscale dans la législation de certains états de la fédération et les tribunaux spéciaux fédéraux. Ensuite, l'étude analyse le Projet de loi $\mathrm{n}^{\circ}$ $5.082 / 2009$, qui vise à réglementer la transaction fiscale au niveau fédéral. Ce projet est une alternative viable pour réduire les litiges devant le juge. Son examen approfondi montre qu'il serait en conformité avec le Droit brésilien et le contexte actuel du Droit fiscal. Néanmoins, il devrait y avoir quelques amendements sur ses dispositions.

Mots-clés: Transaction. Droit fiscal. Coopération fisc-contribuable. 


\section{SUMÁRIO}

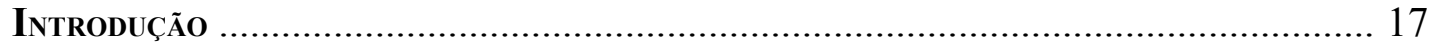

Capítulo I - Transformações no Direito Tributário............................................. 23

1.1. A tributação e suas origens.................................................................... 24

1.1.1. Da pilhagem ao imposto consentido.......................................... 24

1.1.2. Os objetivos da tributação.......................................................... 27

1.2. As preocupações contemporâneas........................................................ 30

1.2.1. Legitimidade social e civismo fiscal......................................... 30

1.2.2. Eficiência na gestão administrativo-tributária............................ 32

1.2.3. Estreitamento das relações fisco-contribuinte............................. 34

1.3. Os novos rumos: o contratualismo fiscal................................................ 37

1.3.1. Discussões acerca dos "contratos fiscais"................................. 38

1.3.2. Instrumentos de contratualismo fiscal...................................... 42

1.3.2.1. Consultas e advance tax rulings................................... 42

1.3.2.2. Os agréments fiscaux do Direito francês.............................45

1.3.2.3. Acordos prévios de preços de transferência..................... 51

1.4. Perspectivas para a resolução de conflitos tributários: a transação......... 54

1.4.1. A transação como método de solução de conflitos no cenário

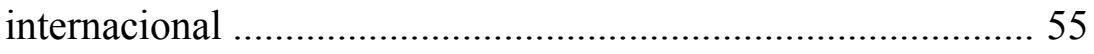

1.4.1.1. A transação tributária no Direito francês........................... 56

1.4.1.2. A transação tributária no Direito italiano............................ 60

1.4.1.3. A transação tributária no Direito norte-americano.............63

Capitulo II - O Falso Dogma da Impossibilidade de Transação em Matéria de

Direito Público no Brasil............................................................................... 68 
2.1. Considerações gerais. 68

2.2. Transação perante os princípios de Direito Público. 71

2.2.1. Legalidade administrativa 71

2.2.2. Indisponibilidade do interesse público. 73

2.2.3. Impessoalidade. 80

2.2.4. Discricionariedade 81

2.2.5. Proporcionalidade e razoabilidade. 83

2.2.6. Eficiência. 85

2.3. Hipóteses de transação em matéria de Direito Público. 87

Capítulo III - TransaÇão em Matéria Tributária no Brasil 91

3.1. Considerações iniciais sobre a transação tributária no Brasil. 91

3.1.1 A origem do instituto no Direito Civil e seus possíveis reflexos no Direito Tributário 92

3.1.2. Controvérsia acerca da natureza contratual do instituto. 96

3.1.3. A transação tributária como forma de extinção do crédito tributário 98

3.1.4. Similitudes e diferenças em relação a outros institutos do Direito Tributário: parcelamento, remissão, anistia e outros ... 101

3.2. Pressupostos da transação tributária conforme art. 171 do CTN . 109

3.2.1. Necessidade de lei autorizadora. 109

3.2.2. Concessões mútuas...... 113

3.2.3. (De)terminação do litígio. 115

3.3. Os possíveis conflitos com o ordenamento jurídico brasileiro. 118

3.3.1. Legalidade tributária (arts. $5^{\circ}$, II e 150, I da CF).

3.3.2. Obrigatoriedade do lançamento e da cobrança do crédito tributário (arts. $3^{\circ}$ e 142 , $\S$ único do $\mathrm{CTN}$ ). 125

3.3.3. Caracterização como renúncia de receitas (art. 14 da LRF). 130 
3.3.4. Igualdade tributária (art. $5^{\circ}$, caput e 150, II da CF).

3.4. Desafios da transação em matéria tributária no contexto brasileiro........138

3.4.1. Desestímulo ao pagamento voluntário...................................... 138

3.4.2. Excesso de discricionariedade e desvios na sua utilização........ 140

3.5. Algumas experiências em vigor no direito interno................................. 144

3.5.1. No Estado de Minas Gerais......................................................... 144

3.5.2. No Estado de Pernambuco....................................................... 147

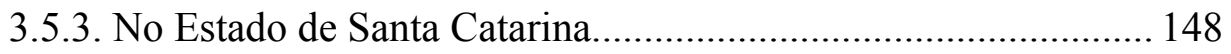

3.5.4. Nos Juizados Especiais Federais (Lei $\mathrm{n}^{\mathrm{o}}$ 10.259/2001).............. 150

Capítulo IV - Análise do Projeto de Lei Geral de Transação Tributária............ 154

4.1. Considerações iniciais sobre o Projeto de Lei $n^{0}$ 5.082/2009 ................ 155

4.2. Disposições gerais do Projeto de Lei $\mathrm{n}^{\circ}$ 5.082/2009.............................157

4.2.1. Procedimento da transação tributária......................................... 159

4.2.2. Abrangência da transação tributária......................................... 162

4.3.Modalidades de transação no Projeto de Lei $n^{0}$ 5.082/2009................. 167

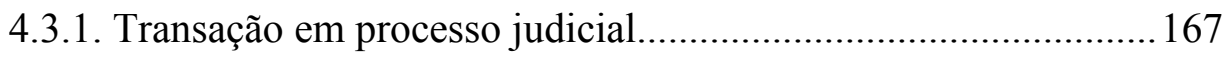

4.3.2. Transação no caso de insolvência civil, falência ou recuperação judicial............................................................... 169

4.3.3. Transação por recuperação tributária......................................... 172

4.3.4. Transação administrativa por adesão.......................................... 174

4.4. Efeitos das etapas do procedimento de transação do Projeto de Lei $\mathrm{n}^{\mathrm{o}} 5.082 / 2009$ 176

4.4.1. Da simples apresentação da proposta de transação..................... 176

4.4.2. Da admissão da proposta de transação....................................... 178

4.4.3. Da celebração da transação e assinatura do respectivo termo.... 184

4.4.4. Do cumprimento das condições e obrigações pactuadas.............188 
4.5. Hipóteses de revogação, nulidade e revisão do termo de transação e suas consequências

4.6. Críticas ao Projeto de Lei $\mathrm{n}^{\circ} 5.082 / 2009$ e propostas de aperfeiçoamento da legislação.

4.6.1. Ampla discricionariedade da Câmara Geral de Transação e Conciliação da Fazenda Nacional e ausência de efetiva independência funcional de seus membros................................................. 196

4.6.2. Ausência de publicidade das decisões relativas à transação...... 198

4.7. Considerações finais acerca do Projeto de Lei $n^{0} 5.082 / 2009 \ldots \ldots \ldots \ldots . . . . .200$

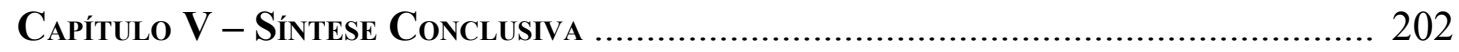

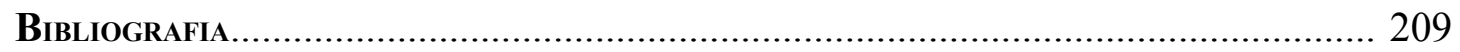

Anexo A - Projeto de Lei Geral de Transação (Projeto de Lei no 5.082/2009)........ 222 


\section{ABREVIATURAS E SIGLAS}

AFRFB - Auditor-Fiscal da Receita Federal do Brasil

AGU - Advocacia-Geral da União

ANEEL - Agência Nacional de Energia Elétrica

ANTT - Agência Nacional de Transportes Terrestres

CADE - Conselho Administrativo de Defesa da Concorrência

CE-Conseil d'État

CGI - Code Général des Impôts

CGTC - Câmara Geral de Transação e Conciliação da Fazenda Nacional

CGU - Controladoria-Geral da União

$\mathrm{CP}$ - Código Penal

CSLL - Contribuição Social sobre o Lucro Líquido

CTASP - Comissão de Trabalho, de Administração e de Serviço Público

CTN - Código Tributário Nacional

DCTF - Declaração de Débitos e Créditos Tributários Federais

DDHC - Declaração dos Direitos do Homem e do Cidadão

DEMAC- Delegacia Especial de Maiores Contribuintes

DF - Distrito Federal

DIGRA - Divisão de Grandes Devedores

DIPJ - Declaração de Informações Econômico-Fiscais da Pessoa Jurídica

DL - Decreto-lei

EATLP - European Association of Tax Law Professors

EC - Emenda Constitucional

EMAG - Escola de Magistrados

EMC - Emenda na Comissão

EUA - Estados Unidos da América

FAQ - Frequently Asked Questions

IBDT - Instituto Brasileiro de Direito Tributário

IPEA - Instituto de Pesquisa Econômica Aplicada

IPTU - Imposto sobre Propriedade Territorial Urbana

IR - Imposto de Renda

IRPJ - Imposto de Renda das Pessoas Jurídicas 
IRS - Internal Revenue Service

ITBI - Imposto sobre Transmissão de Bens Inter vivos

ITCMD - Imposto sobre Transmissão Causa Mortis e Doação

JEF - Juizados Especiais Federais

LC - Lei Complementar

LGT - Lei Geral Tributária

LRF - Lei de Responsabilidade Fiscal

MG - Minas Gerais

OCDE - Organização para a Cooperação e Desenvolvimento Econômico

ORTN - Obrigação Reajustável do Tesouro Nacional

PEC - Proposta de Emenda Constitucional

PGFN - Procuradoria-Geral da Fazenda Nacional

PFN - Procurador da Fazenda Nacional

PL - Projeto de Lei

PLC - Projeto de Lei Complementar

PNEF - Programa Nacional de Educação Fiscal

RE - Recurso Extraordinário

Resp - Recurso Especial

RFB - Receita Federal do Brasil

RPV - Requisição de Pequeno Valor

SDE - Secretaria de Direito Econômico

SISNAMA - Sistema Nacional do Meio Ambiente

STF - Supremo Tribunal Federal

STJ - Superior Tribunal de Justiça

SV - Súmula Vinculante

TAC - Termo de Ajustamento de Conduta

TC - Termo de Compromisso

TFR - Tribunal Federal de Recursos

TRF - Tribunal Regional Federal

UERJ - Universidade do Estado do Rio de Janeiro 


\section{INTRODUÇÃO}

No âmbito do Direito Tributário brasileiro, uma das discussões mais polêmicas (e, ainda assim, pouco estudada) é o instituto da transação em matéria tributária. Em especial, a discussão recai sobre a possibilidade de, considerando as premissas do ordenamento jurídico vigente, colocar-se fim a uma demanda entre fisco e contribuinte por meio de um acordo, com concessões efetuadas por ambas as partes. Nos últimos anos, essa discussão tem ganhado maior destaque notadamente a partir da elaboração de um Projeto de Lei Geral de Transação em matéria tributária (Projeto de Lei $n^{\circ} 5.082 / 2009$ ), que se encontra atualmente em trâmite no Congresso Nacional.

Parte dos advogados e também dos membros da Procuradoria da Fazenda Nacional e da Procuradoria dos Estados e Municípios mostra-se refratária à idéia, sob o argumento de que a implementação do referido instituto violaria a indisponibilidade do interesse público, a legalidade tributária e o próprio conceito de tributo previsto no art. $3^{\circ}$ do CTN, além de outorgar enorme poder discricionário à Administração ${ }^{1}$. No entanto, a tese pela possibilidade de transação entre fisco e contribuinte parece ganhar cada vez mais adeptos $^{2}$. Seus defensores sustentam que não há empecilhos constitucionais ou legais para sua utilização como método de solução de conflitos e justificam a sua adoção pelo ganho em efetividade na resolução dos litígios, pelo menor custo para o Estado e, ainda, pela melhora nas relações com o contribuinte.

Para se chegar a uma conclusão, seja ela a favor ou contra a proposta de implementação da transação em matéria tributária, é preciso analisar o tema com mais profundidade, examinando-o de forma científica, ponderando os argumentos favoráveis e aqueles desfavoráveis à transação, tudo isso em face de um ordenamento específico, no caso, o ordenamento jurídico-tributário brasileiro.

Assim, o presente trabalho tem por objetivo estudar o instituto da transação em um ramo da ciência jurídica em que sua aplicação no Brasil é menos comum, qual seja, o

\footnotetext{
${ }^{1}$ É o caso, por exemplo, de: Hugo de Brito Machado, Eurico Marcos Diniz de Santi, Oswaldo Othon de Pontes Saraiva Filho, Dolizete Fátima Michelin e Simone Anacleto Lopes.

${ }^{2}$ No evento "Soluções Alternativas de Resolução de Conflitos: Arbitragem em Direito Tributário", realizado pela EMAG/TRF-3 $3^{\text {a }}$ Região entre os dias 20 e 21 de junho de 2011 , falou-se não somente da arbitragem como também da transação em matéria tributária, sendo que todos os palestrantes demonstraram-se favoráveis à proposta de transação e arbitragem em matéria tributária. A título ilustrativo, podem ser citados: Diogo Leite Campos, Arnaldo Sampaio de Moraes Godoy, Luis Inácio de Lucena Adams, Cesar Garcia Novoa, além de Gerd Willi Rothmann.
} 
Direito Tributário. É a partir das disposições da Constituição Federal, bem como dos artigos 156, inciso III e 171 do CTN, e das demais normas pertinentes ao tema, que se desenvolve este estudo.

O tema transação em matéria tributária tem como pano de fundo o fato de o Poder Judiciário estar assoberbado de processos e que grande parte deles, especialmente no âmbito da Justiça Federal, refere-se à matéria tributária, em especial, de cobranças físcais ${ }^{3}$. E não há como se falar em efetivo acesso ao Poder Judiciário (e à própria Justiça) se muitos desses litígios demoram quase uma década para serem solucionados ${ }^{4}$. Eis, pois, que a celeridade é uma das principais preocupações dos operadores do direito na atualidade.

A contratação de mais juízes e servidores para fazer frente ao crescente número de processos judiciais não se aparenta como a solução mais viável para dar maior celeridade à tramitação dos processos. É que, uma das grandes mazelas da economia nacional é o alto gasto com o funcionalismo público, que só cresceria com essa medida. E para compensar o aumento dos gastos com o funcionalismo, o Governo seria obrigado a majorar a carga tributária, o que, por sua vez, implicaria no aumento de conflitos com os contribuintes, e assim sucessivamente, em um interminável círculo vicioso.

Ademais, as reformas constitucionais e processuais realizadas até o momento com a finalidade de dar maior celeridade aos processos judiciais não obtiveram o êxito esperado ${ }^{5}$. Outras propostas, ainda em trâmite, com o mesmo escopo, como aquela objeto da PEC n ${ }^{\circ} 15 / 11$ (por alguns denominada de "PEC dos recursos"), que permite que decisões proferidas pelos tribunais sejam executadas ainda que interpostos recursos

\footnotetext{
${ }^{3}$ Citando os dados do Relatório Estatístico de Movimentação Processual do Tribunal Regional Federal da $3^{\text {a }}$ Região tem-se que, dos 1.649.933 processos em trâmite em dezembro de 2012 na Seção Judiciária de São Paulo, 802.056 são execuções fiscais e embargos às execuções fiscais $(48,61 \%$ do total de processos). Disponível em: <http://www.trf3.jus.br/trf3r/index.php?id=2392>. Acesso em: 17 fev. 2013. O Conselho Nacional de Justiça também divulgou o relatório "Justiça em Números 2012", citando os dados referentes à 2011 e indicando que 82\% das execuções perante a Justiça Federal versam sobre matéria fiscal (p. 151 do relatório). Disponível em: <http://www.cnj.jus.br/images/pesquisas-judiciarias/Publicacoes/rel completo federal.pdf $>$. Acesso em: 17 fev. 2013.

${ }^{4} \mathrm{O}$ tempo médio de tramitação de uma execução fiscal na Justiça Federal é de 9 anos e 9 meses, conforme dados extraídos do Comunicado $\mathrm{n}^{\circ}$ 127, de 4 de janeiro de 2012, elaborado pelo IPEA, considerando dados de 2011. Disponível em: <http://www.ipea.gov.br/portal/images/stories/PDFs/comunicado/120103_comuni cadoipea127.pdf $>$. Acesso em: 17 fev. 2013.

${ }^{5}$ Sobre as alterações na Constituição Federal com o intuito de dar maior celeridade processual, destaca-se a $\mathrm{EC} \mathrm{n}^{\circ} 45 / 04$, que criou as súmulas vinculantes e acrescentou o requisito da repercussão geral para os recursos extraordinários perante o STF. Sobre as reformas processuais realizadas com tal desiderato, destacam-se a reforma em relação à forma de cumprimento da sentença (Lei $\left.n^{\circ} 11.232 / 05\right)$, a reforma que estabeleceu, como regra, o agravo retido (Lei $\left.{ }^{\circ} 11.187 / 05\right)$ e a regulamentação da repercussão geral como requisito para a interposição de recurso extraordinário (Lei n $\left.{ }^{\circ} 11.418 / 06\right)$.
} 
especiais e/ou extraordinários, são objeto de infinitos debates ${ }^{6}$.

A maior parte dos processos de natureza tributária em trâmite perante a Justiça Federal consiste em execuções fiscais (e respectivos embargos à execução), cuja lentidão, ineficácia e alto custo para o Poder Público a tornam um mecanismo inadequado e ineficaz para a arrecadação de tributos e para a resolução dos conflitos entre fisco e contribuinte ${ }^{7}$.

Nesse contexto, impõe-se a utilização de meios alternativos de solução de controvérsias, tais como a conciliação, a mediação, a arbitragem e a transação ${ }^{8}$.

Diz-se que esses meios de solução de controvérsias são alternativos porque se contrapõem ao meio contencioso-judicial, mais comumente utilizado pelos cidadãos. Porém, atualmente, em razão do excessivo número de demandas submetidas à apreciação do Poder Judiciário, bem como da demora dos julgamentos e dos intermináveis recursos existentes no sistema jurídico nacional, esse mecanismo não tem se mostrado como um meio efetivo para a solução de conflitos entre as partes.

O tema - a transação em matéria tributária - foi escolhido por sua utilidade prática, como uma alternativa para desafogar o Poder Judiciário, dando efetividade à idéia de justiça e ao princípio que assegura a razoável duração do processo e os meios que garantam a celeridade de sua tramitação, conforme estabelecido pela EC nº 45/04. Ademais, esse tema foi escolhido porque se reveste de singularidade, com reflexos diretos na atuação do candidato, na qualidade de Procurador da Fazenda Nacional.

Embora prevista desde 1966 no CTN, a transação em matéria tributária não foi examinada de modo profundo pelos doutrinadores brasileiros, muito menos pela jurisprudência. São poucas as bibliografias acerca do assunto, tendo sido recentemente

\footnotetext{
${ }^{6}$ Essa PEC acrescenta os arts. 105-A e 105-B ao texto constitucional, propondo a imediata execução das decisões após pronunciamento de segunda instância (TRFs e TJs). Essa proposta encontra-se, atualmente, em trâmite no Senado Federal <http://www.senado.gov.br>. Acesso em: 25 fev. 2013.

${ }^{7}$ Acerca do custo unitário do processo de execução fiscal na Justiça Federal, conferir o Comunicado do IPEA $\mathrm{n}^{\circ}$ 127, de 04 de janeiro de 2012. Nesse relatório, o IPEA destaca que uma execução fiscal custa, em média, R\$ 5.607,67. Disponível em: <http://www.ipea.gov.br/portal/images/stories/PDFs/comunicado/ 120103comu nicadoipea127.pdf>. Acesso em: 17 fev. 2013.

${ }^{8}$ Há quem sustente que essas são, na verdade, "soluções preferenciais" e não unicamente "soluções alternativas" de controvérsias. Esse raciocínio está pautado na idéia de que a Administração deve (poderdever) preferir uma dessas formas de solução de conflitos. Nesse sentido conferir a opinião de Gustavo Justino de Oliveira. (OLIVEIRA, Gustavo Justino de. A Administração Consensual como a nova face da Administração Pública no século XXI: fundamentos dogmáticos, formas de expressão e instrumentos de ação. In: OLIVEIRA, Gustavo Justino de. Direito administrativo democrático. Belo Horizonte: Fórum, 2010, p. 218).
} 
retomados os debates em relação ao tema, ainda que de forma incipiente, em razão do recente Projeto de Lei $n^{\circ} 5.082 / 2009$, proposto pelo Poder Executivo.

Nesse sentido, entende-se ainda que o estudo pode contribuir para o enriquecimento das discussões sobre o tema e, eventualmente, para o aperfeiçoamento do referido Projeto de Lei de transação em matéria tributária. Ademais, poderá também vir a servir de referência para legislações vindouras sobre a matéria que provenham de outras Pessoas Políticas (Estados, DF e Municípios).

Por fim, é importante sublinhar que, além de reduzir a litigiosidade e desafogar o Poder Judiciário, permitindo uma maior celeridade processual, a transação em matéria tributária insere-se no contexto das transformações ocorridas no Direito Tributário nos últimos anos. Nesse sentido, o estudo desse instituto permitirá melhor compreender o estágio atual das relações entre fisco e contribuinte, bem como verificar até que ponto a transação tributária (e outros institutos análogos) pode vir a melhorar esse relacionamento.

A fim de expor com clareza o resultado da pesquisa, o estudo foi segregado em quatro capítulos.

No primeiro capítulo (Capítulo I - Transformações no Direito Tributário), a intenção é de contextualizar o instituto da transação em face das modificações ocorridas no Direito Tributário e a passagem de uma teoria tradicional, focada sobretudo na arrecadação, para uma visão contemporânea. Nesse sentido, pretende-se examinar as origens e fundamentos da tributação, para então chegar às preocupações na atualidade em relação à tributação, com destaque para a legitimidade social, a busca pela eficiência na gestão administrativo-tributária e para o estreitamento das relações fisco-contribuinte. Sob esse aspecto, será examinada a questão do "contratualismo fiscal" e dos instrumentos de negociabilidade em que existe a participação dos contribuintes: advance tax rulings, consultas, agréments fiscaux e acordos prévios em matéria de preços de transferência. Nesse capítulo, a experiência estrangeira em matéria de transação tributária é citada para situar, também no âmbito internacional, a discussão.

No segundo capítulo (Capítulo II - O Falso Dogma da Impossibilidade de Transação em Matéria de Direito Público no Brasil), analisa-se a compatibilidade do instituto da transação em relação a diversos princípios de Direito Público no Brasil, em especial, em relação ao princípio da legalidade, da indisponibilidade do interesse público, da impessoalidade, da discricionariedade, da proporcionalidade e da eficiência. Nesse 
contexto, são estudadas algumas disposições legislativas que permitem a transação em outros ramos do Direito Público. Essa análise tem por finalidade verificar se seria verdadeiro o dogma da impossibilidade de transação pela Administração Pública (em matéria de Direito Público), pressuposto para o raciocínio desenvolvido nas partes seguintes desse estudo, especificamente em relação à matéria tributária.

No terceiro capítulo (Capítulo III - Transação em Matéria Tributária no Brasil), examina-se a transação em matéria tributária propriamente dita, cotejando os diversos aspectos do instituto, sua origem e pressupostos, tomando por base o ordenamento jurídico brasileiro. Nesse capítulo, analisam-se pormenorizadamente as disposições dos artigos 156, III e 171 do CTN, que prevêem a transação como uma das formas de extinção do crédito tributário. A partir dessa análise - com exame crítico das manifestações da doutrina e da jurisprudência - será possível destacar quais são os possíveis conflitos da transação tributária em relação às demais normas do ordenamento jurídico tributário brasileiro: é o caso, por exemplo, da suposta incompatibilidade da transação perante o princípio da legalidade, os arts. $3^{\circ}$ e 142 , § único do CTN e art. 14 da LRF, bem como perante o princípio da igualdade tributária. Os elementos até então desenvolvidos na pesquisa permitirão examinar (e refutar) alguns dos principais desafios mencionados pela doutrina em relação à transação em matéria tributária.

Nesse contexto, serão também analisados alguns exemplos de transação tributária em vigor no direito interno: começando pela legislação de alguns Estados da federação que disciplinaram a questão, adentrando a Lei n. ${ }^{\circ}$ 10.259/01, particularmente no que se refere ao artigo $10^{\circ}$, $\S$ único, que prevê a possibilidade de transação no âmbito dos Juizados Especiais Federais, e terminando pela análise do Decreto n. ${ }^{\circ} 4.250 / 02$, que regulamentou aquele desipositivo. Essa análise serve como elemento para ilustrar as considerações e criticas feitas no mesmo capítulo.

No quarto e último capítulo (Capítulo IV - Análise do Projeto de Lei Geral de Transação Tributária) e, considerando já firmados os principais conceitos e limites do instituto, é feita uma análise aprofundada do Projeto de Lei $n^{\circ} 5.082 / 2009$, que propõe a Lei Geral de Transação em matéria tributária no âmbito federal e que se encontra atualmente em trâmite no Congresso Nacional. A referência a esse Projeto de Lei tem uma intenção clara: confirmar ou refutar os fundamentos teóricos desenvolvidos ao longo da pesquisa face a uma disposição legal específica: o Projeto de Lei $n^{\circ}$ 5.082/2009. Assim, examina-se de maneira crítica o procedimento previsto para a transação tributária, 
a abrangência da transação - se aplicável somente aos acessórios ou também aos tributos propriamente ditos -, as diversas modalidades de transação e suas peculiaridades, bem como os efeitos de cada uma das etapas relacionadas ao procedimento de transação tributária previstas no referido projeto, além das hipóteses de revogação, nulidade e revisão do termo de transação e suas respectivas consequências. Finalmente, são efetuadas críticas pontuais ao Projeto de Lei ${ }^{0} 5.082 / 2009$.

Essas são as principais questões analisadas ao longo do estudo e que permitem, ao final, avaliar a possibilidade de aplicação da transação em matéria tributária como um mecanismo de solução de controvérsias no ordenamento jurídico brasileiro. 


\section{CAPÍTULO I - TRANSFORMAÇÕES NO DIREITO TRIBUTÁRIO}

A transação tributária é um mecanismo de solução alternativa de controvérsias entre fisco e contribuinte em que as próprias partes se compõem para solucionar o litígio por meio de concessões mútuas. Conforme será visto com mais detalhes no decorrer deste capítulo, sua adoção está inserida no contexto das transformações ocorridas no Direito Tributário ao longo do tempo e decorre de uma mudança profunda do sistema tributário, bem como da concepção de legitimidade do próprio tributo 9 .

Na fase atual do Direito Tributário, tem-se observado a necessidade de uma maior participação dos contribuintes no processo que resulta na tributação. Isso ocorre não somente em relação à formação da lei tributária, isto é, durante o processo legislativo, como também em relação à aplicação da norma ao caso concreto, aí incluindo também a etapa de resolução dos conflitos entre fisco e contribuintes. Essa participação visa a assegurar uma maior legitimidade social da tributação, denominada por alguns juristas de "cidadania fiscal"10 e justifica, de certa forma, a adoção da transação como forma de solução de conflitos tributários.

Para melhor compreender as mudanças por que passou (e ainda passa) o Direito Tributário na atualidade, analisar-se-á, neste capítulo, primeiramente, as origens da tributação, com ênfase na sua evolução histórica e objetivos (item 1.1). Posteriormente, serão analisadas algumas características atuais da tributação, com destaque para a preocupação com a legitimidade social da tributação, com a eficiência na gestão administrativo-tributária e com o estreitamento das relações fisco-contribuinte (item 1.2). Após, adentrar-se-á em uma das principais facetas do Direito Tributário contemporâneo, qual seja, o contratualismo fiscal, analisando alguns de seus exemplos mais conhecidos (item 1.3). Por fim, serão apresentadas algumas considerações acerca da transação tributária como método para solução de conflitos, mencionando a experiência estrangeira sobre o tema (item 1.4).

\footnotetext{
${ }^{9}$ CAMPOS, Diogo Leite de. O Sistema Tributário no Estado dos Cidadãos. Coimbra: Almedina, 2006, p. 96.

${ }^{10}$ BOUVIER, Michel. Introduction au droit fiscal général et à la théorie de l'impôt. Paris: L.G.D.J., 2012, p. 175 et seq.
} 


\subsection{A tributação e suas origens}

A evolução da tributação está intrinsecamente ligada ao desenvolvimento da civilização e do próprio Estado. A necessidade de arrecadar tributos sempre existiu, mas, ao longo dos séculos, a forma como se relacionam aqueles que pagam com aqueles que cobram (item 1.1.1) e os objetivos da tributação (item 1.1.2) foram consideravelmente alterados.

\subsubsection{Da pilhagem ao imposto consentido}

Não há um marco temporal específico para o surgimento dos tributos e parece destinada ao insucesso a tarefa de identificar a civilização que poderia ser reconhecida como o berço da tributação. O que parece mais correto é que o tributo tenha nascido antes mesmo do advento do Estado ${ }^{11}$, em formas primitivas de cobrança da Antiguidade.

Aponta-se que o tributo só nasceu a partir do momento em que o homem foi capaz de produzir além do necessário para a sua sobrevivência, acumulando bens ou formando estoques. Esse acúmulo passou a ser objeto de desejo de outros grupos sociais que, por diversos motivos, apropriavam-se do excedente produzidos pelas demais comunidades, realizando as pilhagens ${ }^{12}$.

Nas civilizações antigas, o tributo aparece, na maioria dos casos, como uma prerrogativa do vencedor sobre o vencido, do homem livre sobre o escravo, daquele que pertence à sociedade em relação ao estrangeiro. Como descreve Luís Eduardo Schoueri, originalmente, os cidadãos, os homens livres, não estavam sujeitos ao pagamento de tributos, sendo que estes eram uma consequência da falta de liberdade ${ }^{13}$.

Na Idade Média, além de não existir uma organização política centralizada, não havia um sistema tributário unificado; as formas e métodos de cobrança de tributos variavam consideravelmente de um lugar para o outro, de acordo com os domínios

\footnotetext{
${ }^{11}$ A própria época do surgimento do Estado é controvertida. Como pontuado por Dalmo de Abreu Dallari, inúmeras são as teorias a esse respeito. No entanto, podem ser reduzidas a três posições principais: a) a primeira, segundo a qual o Estado e sociedade sempre existiram; b) uma segunda teoria, segundo a qual o Estado teria surgido posteriormente à sociedade, para atender às necessidades e conveniências do grupo social; e, por fim (c) uma terceira teoria, segundo a qual o Estado seria uma sociedade política dotada de certas características bem definidas, notadamente a soberania, tendo surgido somente a partir do século XVII (DALlARI, Dalmo de Abreu. Elementos de Teoria Geral de Estado. São Paulo: Saraiva, 2013, p. 60).

${ }^{12}$ BOUVIER, Michel. Introduction au droit fiscal général et à la théorie de l'impôt. Paris: L.G.D.F., 2012, p. 165.

${ }^{13}$ SCHOUERI, Luís Eduardo. Direito Tributário. São Paulo: Saraiva, 2013, p. 19 et seq.
} 
feudais. Os tributos eram, em sua maioria, cobrados pelo senhor feudal em situações excepcionais (e.g. para financiar guerras, casamentos ou mesmo pagar recompensas). É nessa época que alguns autores situam o nascimento da tributação como contraprestação, sendo o tributo o preço pago pela proteção e segurança que o senhor oferecia a seus $\operatorname{servos}^{14}$.

Também data da Idade Média as primeiras limitações ao poder de tributar, isto é, regras visando a coibir os abusos e excessos cometidos por parte dos reis e senhores feudais. É nesse contexto que se insere a Carta Magna, assinada por João Sem Terra em $1215^{15}$. O estatuto estabelecia, entre outras garantias, algumas condições para a exigência de tributos: esses somente poderiam ser cobrados com o consentimento do conselho geral do reino, para armar cavaleiro o filho mais velho e para celebrar, uma única vez, o casamento da filha mais velha, e desde que preservados limites razoáveis ${ }^{16}$.

Os tributos passam a ter importância fundamental no Regime Absolutista. A unificação de um sistema tributário em escala nacional era um objetivo da monarquia, já que a uniformidade tributária auxiliava a centralizar o poder, as riquezas, contrapondo-se à dispersão política da Idade Média. Nessa época, buscou-se também transformar os tributos - até então, quase sempre esporádicos - em perenes. Porém, os privilégios e gastos excessivos das cortes absolutistas aliados a uma tributação excessiva, injusta e arbitrária, deram ensejo às revoltas populares, entre as quais, as de maior repercussão mundial: a Independência dos Estados Unidos e a Revolução Francesa. Essas tiveram, entre tantas outras consequências, limitar o poder de tributar estatal.

A independência dos Estados Unidos foi seguida, alguns anos mais tarde, da

\footnotetext{
${ }^{14}$ Citando a questão 66 da Suma Teológica de São Tomás de Aquino, segundo a qual "Os governantes que exigem por justiça dos súditos o que estes lhes devem, para a conservação do bem comum, não cometem rapina, mesmo se violentamente, o exigirem ", Roberto Ferraz afirma que é na Idade Media que são lançadas as bases da tributação para que o tributo seja orientado à promoção do bem comum. (FERRAZ, Roberto. Liberdade e tributação: a questão do bem comum. Disponível em: <http://www.hottopos.com/ convenit4/ferraz.htm>. Acesso em: 09 fev. 2013).

${ }^{15}$ Luís Eduardo Schoueri destaca que, embora seja a referência mais comum, a Carta Magna não é o nascimento do princípio de consentimento da tributação. Outros documentos mais antigos também refletem, em certa dose, o necessário consentimento para a cobrança do imposto. (SCHOUERI, Luís Eduardo. Direito Tributário. São Paulo: Saraiva, 2013, p. 280).

${ }^{16}$ Como destaca Gerd Willi Rothmann, o art. XII da Magna Carta estabelecia que: "no scutage or aid shall be imposed on our kingdom unless by the common counsel of our kingdom, except for ransoming our person, for making our eldest son a knight, and for once marrying our eldest daughter, and for these there shall not be levied more than a reasonable aid". (ROTHMANN, Gerd Willi. O princípio da legalidade tributária. In: NOGUEIRA, Ruy Barbosa. Direito Tributário: Estudo de casos e problemas. São Paulo: José Bushatsky, 1973, p. 147). Sobre o princípio da legalidade, cuja origem remonta à Carta Magna e seu desenvolvimento ao longo dos séculos, bem como sobre a compatibilidade do instituto da transação tributária para com este, conferir item 3.3.1. deste trabalho.
} 
Constituição norte-americana de 1787, onde atribuiu-se expressamente ao Congresso, órgão de representação popular, o poder de estabelecer e cobrar impostos, taxas e tributos em geral, para pagar dívidas e prover o bem-estar geral dos Estados Unidos ${ }^{17}$. A Revolução Francesa e a Declaração dos Direitos do Homem e do Cidadão de 1789 (DDHC) também não foram apenas marcos sociais, consolidando dois dos principais fundamentos da tributação: (i) o tributo como prestação pecuniária necessária ao funcionamento da sociedade e à consecução de seus fins (princípio da necessidade); e (ii) a necessidade de consentimento dos representantes do povo para a criação de tributos (princípio da legalidade ou princípio do consentimento) ${ }^{18}$. O poder de tributar deixou, assim, de ser absoluto, cabendo ao povo consentir com o pagamento dos tributos.

O consentimento do povo, manifestado por meio da lei, é que legitimava e autorizava a tributação. A esse respeito, Gerd Willi Rothmann destaca que a autorização em relação à cobrança dos tributos por aqueles que devem pagá-los é que distinguia a tributação da simples desapropriação, tornando-a consentida ${ }^{19}$. E esse consentimento somente era manifestado quando se julgasse que aqueles recursos eram efetivamente necessários para financiar a estrutura e as despesas relacionadas ao funcionamento da sociedade. As leis tributárias aprovadas pelo Parlamento representavam o Direito Tributário da época. Não se admitia contestação em relação aos tributos que foram consentidos pelo próprio povo ou por seus representantes por meio da lei ${ }^{20}$.

Os fundamentos revolucionários influenciaram a construção dos sistemas jurídicos tributários vindouros. A idéia de um tributo consentido pelos representantes do povo e

\footnotetext{
${ }^{17}$ Conforme Gerd Willi Rothmann, esse dispositivo encontrava-se no art. $1^{\circ}$, Seção $8^{a}$ da Constituição norte-americana, que em sua redação original estabelecia ser competência do Congresso o poder: "to lay and collect taxes, duties, imposts and excises, to pay debts and provide for the common deference and general welfare of the United States." (ROTHMANN, Gerd Willi. O princípio da legalidade tributária. In: NOGUEIRA, Ruy Barbosa. Direito Tributário: Estudo de casos e problemas. São Paulo: José Bushatsky, 1973, p. 148).

${ }^{18}$ BOUVIER, Michel. Introduction au droit fiscal général et à la théorie de l'impôt. Paris: L.G.D.J., 2012, p. 163-164. Sobre o princípio da necessidade, pode-se dizer que esse princípio encontra-se expresso no art. 13 da DDHC: "Pour l'entretien de la force publique, et pour les dépenses d'administration, une contribution commune est indispensable". Sobre o princípio da legalidade ou consentimento, este encontrase previsto no art. 14 da DDHC: "Les citoyens ont le droit de constater, par eux-mêmes ou par leurs représentants, la nécessité de la contribution publique, de la consentir librement, d'en suivre l'emploi, et d'en déterminer la quotité, l'assiette, le recouvrement et la durée." Uma versão da DDHC encontra-se disponível em <http://www.textes.justice.gouv.fr/textes-fondamentaux-10086/droits-de-lhomme-et-libertesfondamentales-10087/declaration-des-droits-de-lhomme-et-du-citoyen-de-1789-10116.html>. Acesso em: 09 fev. 2013.

${ }^{19}$ ROTHMANN, Gerd Willi. op. cit., p. 148.

${ }^{20}$ DACOMO, Natalia de Nardi. Direito Tributário participativo: transação e arbitragem administrativas da obrigação tributária. Tese (Doutorado em Direito), Faculdade de Direito da Pontifícia Universidade Católica de São Paulo, 2008, p. 16.
} 
essencial para a vida em sociedade é a base de grande parte dos ordenamentos jurídicos. Evidentemente, a forma como esse consentimento é revelado não é única, já que cada ordenamento jurídico possui suas próprias regras. De toda forma, a idéia de um tributo consentido, consentimento jurídico advindo de norma aprovada pelos representantes do povo, foi sendo consolidada ao longo do tempo, até chegar ao estágio atual, em que parece difícil admitir um tributo que não seja autorizado pelo povo ou seus representantes.

\subsubsection{Os objetivos da tributação}

A evolução da tributação é percebida também quando são investigados os objetivos perseguidos pelo Estado quando do exercício de sua atividade tributária ${ }^{21}$.

O primeiro e mais evidente objetivo da tributação parece ser o de obter recursos para financiar as despesas do Estado ${ }^{22}$. Por meio da instituição de tributos, uma parcela da riqueza do particular é transferida ao Poder Público, para a realização de seus fins, no atendimento das necessidades coletivas ${ }^{23}$. Assim, a tributação é o que permite que o Estado realize seu papel em benefício da sociedade; ou, como disse Oliver Wendell Holmes: "Imposto é o que pagamos por uma sociedade civilizada"24.

Luís Eduardo Schoueri aponta que, à época do Estado Patrimonial, quando o Estado atuava diretamente na economia, os recursos provinham também da exploração do

\footnotetext{
${ }^{21}$ Não há consenso na doutrina sobre quantos (e quais) seriam os objetivos da tributação. Reuven AviYonah cita três objetivos principais da tributação, quais sejam, a arrecadação, a redistribuição de renda e a regulamentação. (AVI-YONAH, Reuven S. The three goals of taxation. Disponível em: $<$ http://papers.ssrn.com/sol3/papers.cfm?abstract-id=796776.> Acesso em: 11 fev. 2013). Por sua vez, Luís Eduardo Schoueri cita, além dos objetivos mencionados pelo professor americano, a função estabilizadora dos tributos. (SCHOUERI, Luís Eduardo. Direito Tributário. São Paulo: Saraiva, 2013, p. 36-37). Por fim, Andréa Lemgruber Viol faz referência ainda à finalidade política, de criar um elo entre cidadão e Governante. (VIOL, Andréa Lemgruber A Finalidade da Tributação e sua Difusão na Sociedade. Disponível em: <http://www.receita.fazenda.gov.br/Historico/EstTributarios/eventos/Seminario/htm>. Acesso em: 11 fev. 2013). Nesse trabalho, por acreditar que algumas funções estão, de certa forma, compreendidas nas demais, adota-se a mesma classificação de Reuven Avi-Yonah.

${ }^{22}$ Esse objetivo eminentemente arrecadatório já estava expresso na Declaração dos Direitos do Homem e do Cidadão de 1789, que estabelece em seu artigo 13, que a contribuição de todos os cidadãos é essencial para a manutenção da força pública e para as despesas da Administração. Conforme art. 13 da DDHC: "Pour l'entretien de la force publique, et pour les dépenses d'administration, une contribution commune est indispensable". Disponível em <http://www.textes.justice.gouv.fr/textes-fondamentaux-10086/droits-delhomme-et-libertes-fondamentales-10087/declaration-des-droits-de-lhomme-et-du-citoyen-de-1789-10116. html > Acesso em: 09 fev. 2013.

${ }^{23}$ ROTHMANN, Gerd Willi. O princípio da legalidade tributária. In: NOGUEIRA, Ruy Barbosa. Direito Tributário: Estudo de casos e problemas. São Paulo: José Bushatsky, 1973, p. 140. Sobre a compatibilidade do instituto da transação com o princípio da legalidade administrativa, conferir item 2.2.1 deste trabalho.

${ }^{24}$ Compania Gen. De Tobacos de Filipinos v. Collector of Internal Revenue, 227 US 87, 100 (1927). Disponível em: <http://supreme.justia.com/cases/federal/us/275/87/case.html>. Acesso em: 9 mar. 2013.
} 
patrimônio estatal e dos serviços prestados ${ }^{25}$. Com a propagação da doutrina liberal e a diminuição considerável da interferência na economia, o Estado passa a se valer cada vez mais da apropriação de riquezas que não foram por ele geradas para conseguir realizar as suas atribuições ${ }^{26}$. A tributação ganha, então, papel de destaque nas finanças estatais.

A ascensão do Estado Social (Social Welfare) também tem relevância na análise dos objetivos da tributação. Para assegurar programas sociais característicos desse Estado do bem-estar coletivo, que se propõe a garantir uma série de direitos a seus cidadãos, os países foram obrigados a ampliar a base de arrecadação. Ainda aqui, a arrecadação como objetivo primordial da tributação.

É também nesse período que desponta o segundo objetivo da tributação, qual seja, o esforço em redistribuir a riqueza. Por meio da tributação, que deve incidir de maneira mais gravosa sobre os mais ricos e afetar pouco os mais pobres, a riqueza dos indivíduos é transferida, na tentativa de alcançar um maior equilíbrio social. A tributação da renda, do patrimônio e, mais especificamente, a tributação de grandes fortunas estão inseridas nessa lógica redistributiva ${ }^{27}$. Michel Bouvier destaca que a finalidade redistributiva é também a justificativa para a adoção de um "imposto-negativo", alocação concedida por certos governos (entre os quais, a França) para garantir uma renda mínima aos indivíduos ${ }^{28}$. Em síntese, é o tributo a serviço de uma sociedade mais igualitária.

Importa destacar que a forma de estruturar o sistema tributário é de suma importância para a concretização do objetivo redistributivo. Avi-Yonah aponta que a escolha pela tributação da renda/patrimônio é uma opção óbvia para esse fim, na medida em que onera com maior severidade os mais ricos (aqueles que detém maior renda ou patrimônio, em detrimento dos menos favorecidos); porém, reconhece que a utilização da tributação da renda/patrimônio como método redistributivo gera problemas do ponto de

\footnotetext{
${ }^{25}$ SCHOUERI, Luís Eduardo. Direito Tributário. São Paulo: Saraiva, 2013, p. 24.

${ }^{26}$ Andréa Lemgruber Viol salienta que a tributação não é a única fonte possível de recursos para o Estado (a autora cita a pilhagem, a cunhagem de dinheiro, o endividamento, a venda de bens e serviços públicos e a apropriação de recursos econômicos), mas é a mais amplamente utilizada nos dias atuais. Na visão da autora, a tributação é a única fonte de recursos do Estado que permite estabelecer um vinculo entre cidadania e responsabilidade social. Ainda, as demais fontes de financiamento ou são inadequadas ao momento histórico ou não são sustentáveis a longo prazo. (VIOL, Andréa Lemgruber. A Finalidade da Tributação e sua Difusão na Sociedade. Disponível em: <http://www.receita.fazenda.gov.br/Publico/estudo tributarios/Eventos/SeminarioII/Texto02AFinalidadedaTributacao.pdf $>$. Acesso em: 11 fev. 2013).

${ }^{27}$ LAMARQUE, Jean; NÉGRIN, Olivier; AYRAULT, Ludovic. Droit fiscal général. Paris: LexisNexis, 2011, p. 1015.

${ }^{28}$ BOUVIER, Michel. Introduction au droit fiscal général et à la théorie de l'impôt. Paris: L.G.D.J., 2012, p. 288.
} 
vista político e administrativo ${ }^{29}$. Por isso, a importância de combinar a tributação da renda/patrimônio com a tributação do consumo, bem como destinar recursos a programas sociais e assim permitir que os menos favorecidos alcancem estágios sociais mais avançados. Andréa Lemgruber Viol ressalta, porém, a incapacidade de a tributação, por si só, atingir o objetivo de redistribuir riquezas e transformar a sociedade ${ }^{30}$. Com efeito, a finalidade redistributiva não pode ser olvidada quando da elaboração da política fisscal, ainda que conscientes que outros instrumentos devem ser implementados para atingir maior igualdade social.

Por fim, um terceiro objetivo da tributação é aquele indutor de comportamentos. Valendo-se do tributo como um instrumento, o Estado estimula ou desestimula comportamentos e altera assim, o ambiente sócio-econômico. O Estado cria incentivos ou agrava a tributação, concede créditos, regimes especiais ou majora a alíquota e assim consegue influenciar a conduta do contribuinte, atingindo um objetivo que não é fiscal.

Luís Eduardo Schoueri ressalta que, juntamente com outras normas criadas por razões não fiscais, as normas indutoras integram o gênero extrafiscalidade e fazem parte do subgrupo que pode ser qualificado como "extrafiscalidade em sentido estrito" ${ }^{31}$. No entanto, são normas que, embora movidas por razões estranhas à fiscalidade, não perdem a característica de serem relativas a tributos e, portanto, submetidas a princípios e regras do Direito Tributário, ainda que, por vezes, esses princípios sejam mitigados ${ }^{32}$.

De certa forma, esse objetivo é contrário ao pensamento liberal clássico, que pregava a neutralidade fiscal e que a participação do Estado não deveria perturbar o ambiente econômico ${ }^{33}$. O caráter indutor da norma tributária é justamente o reconhecimento de que ela não é neutra e que servirá como instrumento para que o Estado intervenha na economia ou na sociedade.

\footnotetext{
29 AVI-YONAH, Reuven S. The three goals of taxation. Disponível em: <http://papers.ssrn.com/sol3/ papers.cfm?abstract-id=796776.> Acesso em 11 fev. 2013.

${ }^{30}$ VIOL, Andréa Lemgruber. A Finalidade da Tributação e sua Difusão na Sociedade. Disponível em: <http://www.receita.fazenda.gov.br/Publico/estudotributarios/Eventos/SeminarioII/Texto02AFinalidadeda Tributacao.pdf>. Acesso em: 11 fev. 2013.

${ }^{31}$ SCHOUERI, Luís Eduardo. Normas tributárias indutoras e intervenção econômica. São Paulo: Forense, 2005, p. 32-33.

32 A esse respeito, conferir SCHOUERI, Luís Eduardo. Normas tributárias indutoras e intervenção econômica. São Paulo: Forense, 2005, p. 225 et seq.

33 Sobre a neutralidade fiscal conferir ELALI, André; LUCENA, Fernando. Visão Critica sobre as Teorias da Neutralidade e não Discriminação da Tributação. In: OLIVEIRA, Ricardo Mariz; SCHOUERI, Luís Eduardo; e ZILVETTI, Fernando Aurélio (Coord.). Direito Tributário Atual, São Paulo, n. 26, 2011, p. 158168.
} 
$\mathrm{Na}$ atualidade, é reconhecido que os tributos tem um papel regulatório cada vez maior, não havendo controvérsias significativas quanto ao fato de que os tributos criados poderão (ou deverão) afetar o comportamento dos agentes econômicos.

\subsection{As preocupações contemporâneas da tributação}

A história da tributação é contínua e, por isso, não há um rompimento entre um modelo clássico ou tradicional e um modelo contemporâneo. Disso resulta que as características e objetivos da tributação, presentes na origem, perpetuaram-se no tempo e terminaram por se identificar com as características e objetivos da tributação na atualidade. Isto é, o consentimento ao imposto por ato dos representantes do povo e os objetivos da tributação citados acima são elementos presentes também em uma análise contemporânea da tributação ${ }^{34}$. No entanto, verificam-se na atualidade algumas novas preocupações, entre as quais destacam-se: a legitimidade social do tributo (item 1.2.1); a eficiência na gestão administrativo-tributária (item 1.2.2); e o estreitamento das relações fisco-contribuinte (item 1.2.3).

\subsubsection{A legitimidade social do tributo: a cidadania fiscal}

Se o tributo nasceu e se desenvolveu como resultado de um poder político e da necessidade de obter recursos para financiar as despesas de uma determinada comunidade, que lhe dava uma legitimidade política e jurídica, hoje vê-se a busca também por uma maior legitimidade social do tributo.

O consentimento do povo, manifestado por meio de lei, decorrência do princípio da legalidade tributária, não parece mais ser suficiente para dar sustentação a um sistema tributário efetivo e funcional. O tributo deve ter, ainda, uma legitimidade social e ser aceito como uma decorrência do exercício da cidadania.

De fato, a cobrança de um tributo pode ser reconhecida como correta do ponto de vista jurídico, por respeitar as regras e princípios tributários vigentes. Nesse cenário, o tributo é consentido pelo cidadão, posto decorrer de lei. E, uma vez legitimado por lei, o tributo poderá ser exigido e provavelmente será pago, ainda que para isso o Estado seja

\footnotetext{
${ }^{34}$ De fato, o adjetivo "contemporâneo" utilizado nesse tópico não tem a intenção de segregar a análise quanto a um momento preciso e definido da história, nem salientar um rompimento com o modelo passado. A utilização do termo "contemporâneo" tem somente a função de destacar o fato de que determinadas características da tributação só ganharam importância em tempos recentes.
} 
obrigado a exercer seus poderes de imperium, com a expropriação forçada do patrimônio do particular.

Entretanto, se outros fatores não estiverem presentes, a cobrança do tributo, embora legal, não será aceita pelo cidadão, que resistirá, seja exercendo práticas de uma economia informal, seja transferindo sua atividade para escapar da incidência geográfica do imposto, seja simplesmente sonegando. A tributação será válida, porém a eficiência do sistema fiscal contestado ficará comprometida.

Os fatores que asseguram legitimidade social à tributação podem até ser estranhos à relação jurídico-tributária; muitas vezes são fatores sociais, financeiros ou políticos. A legitimidade da tributação pode estar pautada na correta destinação do produto da arrecadação tributária, na transparência nas relações com o fisco, ou mesmo no sentimento do contribuinte de que a carga tributária é adequada, igualitária e justa. Todos esses elementos independem do consentimento do tributo revelado pelos representantes do povo quando da elaboração das leis tributárias. Porém, é inegável a influência destes elementos na aceitação dos tributos e na efetividade do sistema tributário.

Marco Aurélio Greco ressalta que o Estado não está investido de um mero poder de tributar, mas sim de uma função; e dessa constatação decorrem diversas consequências práticas, entre as quais, a assertiva de que a função de tributar - ao contrário do poder não se legitima pela mera investidura, mas também pelo seu desempenho. Deve existir um controle sobre a efetiva aplicação dos recursos arrecadados, tanto em termos de destinação, como também de economicidade da aplicação à luz das políticas públicas ${ }^{35}$.

A legitimidade social do tributo pode ser traduzida na cidadania fiscal; isto é, a compreensão (e aceitação) do tributo como um desdobramento da atividade cívica.

Michel Bouvier destaca o papel da Administração fiscal na construção da cidadania fiscal, afirmando que o consentimento dos cidadãos em relação ao tributo não se verifica apenas no papel desempenhado pelo parlamento quando da aprovação da lei que autoriza a tributação, mas também pela efetiva prática administrativa, sendo a Administração fiscal o vetor desse consentimento ${ }^{36}$. Esse fenômeno ele chama de "nova

35 GRECO, Marco Aurélio. Do Poder à Função Tributária. In: FERRAZ, Roberto (Coord). Princípios e limites da tributação 2 - Os princípios da ordem econômica e a tributação. São Paulo: Quartier Latin, 2009 , p. 175.

${ }^{36}$ BOUVIER, Michel. Les transformations de la légitimité de l'impôt dans la société contemporaine. In: DERZI, Misabel Abreu Machado (Coord.). Revista Internacional de Direito Tributário, Belo Horizonte, vol. 1., n. 2., jul/dez 2004, p. 365. 
cidadania fiscal" ${ }^{\prime 37}$.

E, a importância dessa legitimidade social do tributo, ou da construção da cidadania fiscal é deveras relevante quando se constata as particularidades do cenário contemporâneo: um mercado sem fronteiras definidas, com uma diversidade de agentes econômicos e onde as maiores riquezas estão ligadas a bens intangíveis, tornando extremamente difícil o exercício dessa função estatal de tributar. Nesse contexto, os valores de cidadania fiscal são relevantes para própria efetividade da tributação.

As ações para desenvolver a cidadania fiscal são múltiplas, entre as quais podem ser destacadas: (a) a busca por uma maior eficiência na gestão administrativo-tributária; e (b) o estreitamento das relações entre fisco e contribuintes.

\subsubsection{Eficiência na gestão administrativo-tributária}

Conforme antecipado, uma das maiores preocupações da Administração tributária na atualidade recai sobre a gestão administrativo-tributária. Um de seus objetivos é arrecadar a maior quantidade de recursos possíveis com o mínimo de gastos. Vislumbrase a busca por resultados, medidos por diversos indicadores (e.g. valores da arrecadação x custo de arrecadação) e por uma melhor performance dos administradores públicos. Essa preocupação está embasada constitucionalmente no princípio da eficiência que permeia toda Administração Pública, inclusive a Administração tributária ${ }^{38}$.

Em matéria de Administração tributária, essa busca por resultados pode refletir na concentração de recursos humanos e materiais para fiscalizar aqueles contribuintes e ramos de atividade com maior potencial econômico. É o denominado risk management. Em vários países, foram criados órgãos especializados com atribuição específica de fiscalizar e cobrar tributos dos grandes contribuintes ${ }^{39}$. Outro exemplo é o desenvolvimento de sistemas capazes de reconhecer incongruências nas declarações dos

\footnotetext{
37 Tradução livre do original "nouveau civisme fiscal".

${ }^{38}$ Importa destacar que a eficiência na arrecadação tributária já era defendida por Adam Smith. Entre suas máximas tributárias encontravam-se a igualdade, a certeza, a conveniência e a economia (também chamada de eficiência). Tratando da economia na arrecadação, o renomado autor escocês pregava que os custos com a arrecadação deveriam ser limitados ao mínimo, evitando-se desperdícios dos valores arrecadados. No original: "Every tax ought to be so contrived as both to take out and to keep out of the pockets of the people as little as possible, over and above what it brings into the public treasury of the state" (SMITH, Adam. The Wealth of Nations. Introd. by KRUEGER, Alan B. New York: Bantam, 2003, p. 1044).

${ }^{39}$ No Brasil, isso pode ser evidenciado, em âmbito federal, na Receita Federal do Brasil (RFB), com a criação da Delegacia Especial de Maiores Contribuintes (DEMAC) e na Procuradoria-Geral da Fazenda Nacional (PGFN), com a Divisão de Grandes Devedores (DIGRA).
} 
contribuintes, sem necessidade de proceder a uma fiscalização individualizada, reduzindo, assim, os gastos com a fiscalização.

A busca pela eficiência não significa necessariamente o aumento da tributação (aumento da alíquota, alargamento da base e redução das isenções), podendo também se refletir na adequada eleição dos signos de riqueza sobre os quais recairá a tributação (tributação sobre consumo, sobre patrimônio ou sobre rendimentos). Por exemplo, a prevalência da tributação sobre o consumo em relação àquela sobre o patrimônio e sobre o rendimento é criticada por alguns por não alcançar a finalidade redistributiva, mas é justificável do ponto de vista da eficiência administrativa, na medida em que existe uma menor rejeição dos contribuintes e uma maior facilidade na sua arrecadação.

Também é exemplo dessa busca por uma maior eficiência, a criação de novas técnicas de arrecadação (e.g. retenção pela fonte pagadora, substituição tributária) e o incremento das denominadas auto-declarações: formulários que devem ser preenchidos com informações e que devem ser periodicamente apresentadas pelo próprio contribuinte $^{40}$. Essa mudança de formatação da forma de apurar e pagar o imposto - antes exclusivamente do Estado, hoje com participação relevante do contribuinte - resulta também na transferência de responsabilidade: o contribuinte deve pagar multas na hipótese de erro no preenchimento das referidas declarações, ainda que esses erros não resultem de fraude nem de negligência por parte do contribuinte $^{41}$. Tal técnica, evidentemente, reduz os custos do Estado com a fiscalização ${ }^{42}$.

Demais disso, percebe-se, também, um esforço crescente da Administração fiscal em prestar um serviço de qualidade, ampliando os horizontes antes restritos aos objetivos de melhor fiscalizar e melhor arrecadar. Nos dias de hoje, privilegia-se, no âmbito da Administração tributária, uma prestação de serviços eficiente e a satisfação do

\footnotetext{
${ }^{40}$ A esse respeito, deve-se ressaltar que as denominadas auto-declarações em matéria de Direito Tributário não são tão novas. Se é verdade que o número de auto-declarações de responsabilidade do contribuinte aumentou muito nas últimas décadas, não é menos verdade que sua origem remonta ao direito romano, onde o cidadão era obrigado a declarar sua situação, aquela de sua família e sua propriedade diante do censo. Nesse sentido, detaca Carlo Romano: "Some rudiments of forms of participation of the citizens to the functioning of the system may be identified in the ancient legal systems, such as, for example, in the declaration of the citizen of his situation, of his family and of his property before de censor (forma censualis). This forma censualis may be regarded as the first example of a tax return, keystone of the modern self-declaratory or self-assessment system". (ROMANO, Carlo. Advance Tax Rulings and Principles of Law: Towards an European Tax Ruling System?, IBFD, 2002, p. 9).

41 J. ELLIS, Maarten. General Report, Advance Rulings. In: Cahiers de droit fiscal internacional. Netherlands, Vol. LXXXIVb, 1999, p. 24.

${ }^{4}$ Conforme será analisado no item 1.2.3, o aumento das denominadas auto-declarações, com a consequente transferência da responsabilidade pelo seu preenchimento para o contribuinte, acarretou também a necessidade do fisco aulixiar o contribuinte.
} 
contribuinte. Este passa inclusive a ser denominado "usuário" pela legislação de alguns países $^{43}$, revelando, assim, a tendência de aplicar conceitos de mercado nas relações dos cidadãos com o poder publico. $\mathrm{O}$ usuário satisfeito paga mais e melhor.

De outra parte, observa-se uma maior preocupação em controlar os gastos com a Administração Pública, e nesse grupo, a Administração fiscal. Nesse particular, foi publicada, no Brasil, a Lei Complementar $n^{\circ}$ 101/2000, que limitou o gasto em todas as esferas da Administração Pública direta e indireta, estabeleceu condições para a renúncia de receitas, bem como previu a responsabilidade pessoal dos agentes públicos que descumprissem os preceitos nela estabelecidos. Esta lei é considerada um marco da responsabilidade fiscal na gestão de recursos governamentais.

Ainda a esse respeito, importa ressaltar a recente criação de mecanismos para dar maior transparência aos gastos públicos: é o caso, no Brasil, do portal de transparência do governo federal, mantido pela Controladoria-Geral da União ${ }^{44}$. Também com esse objetivo é que foi publicada, recentemente, a Lei $\mathrm{n}^{\circ} 12.527$, de 18 de novembro de 2011 (Lei de Acesso à Informação). Conforme se observa de seu art. $3^{\circ}$, entre as diretrizes desta norma, encontra-se justamente: o desenvolvimento de uma cultura de transparência, assim como do controle social da Administração Pública.

Enfim, todos esses elementos são citados como exemplos de iniciativas para melhorar os índices de gestão administrativo-tributária, o que denota a busca da Administração fiscal por melhores resultados.

\subsubsection{Estreitamento das relações fisco-contribuinte}

Além da busca pela maior eficiência na gestão administrativo-tributária, tem-se observado também nos últimos anos uma tendência da Administração fiscal de buscar o estreitamento de suas relações com os contribuintes como forma de conferir maior legitimidade social e obter uma maior aceitação da tributação pelos contribuintes.

A participação dos contribuintes no processo de tributação (e dos cidadãos em

\footnotetext{
${ }^{43}$ Nesse sentido, importa ressaltar as palavras de Michel Bouvier, professor da Universidade de Paris I Panthéon-Sorbonne, segundo o qual: "Intégré dans un environnement marchand, l'impôt change de nature; il apparaît de plus en plus comme le prix d'un service rendu par l'institution qui en bénéficie plutôt que comme l'expression d'un lien de solidarité, voire même d'un devoir social." (BOUVIER, Michel. Introduction au droit fiscal général et à la théorie de l'impôt. Paris: L.G.D.J., 2012, p. 175).

${ }^{44}$ Para maiores informações sobre os gastos públicos, recomenda-se a visita ao portal da transparência do Governo Federal, disponível em: <http://www.portaldatransparencia.gov.br $>$.
} 
geral na Administração) é resultado da abertura do diálogo entre fisco e contribuinte no âmbito do Direito Tributário (e entre Administração e cidadãos no Direito Administrativo). Decorre de uma nova dinâmica nos Estados modernos, onde perde força a noção de ius imperium, em que o Estado atua por meio de atos impositivos, e ganha importância aquela de Estado democrático, em que este busca garantir os direitos dos cidadãos ${ }^{45}$.

Nesse contexto, verifica-se uma mudança das relações entre fisco e contribuinte: de uma relação de confronto, para uma relação de cooperação. Percebe-se um esforço do fisco em estabelecer um ambiente no qual prevaleça a confiança mútua e a colaboração com os particulares ${ }^{46}$. Em outras palavras, um ambiente no qual, por meio do diálogo, seja possível obter uma solução eqüitativa em caso de eventual divergência. Enfim, busca-se uma maior participação do contribuinte e até o consenso deste em matéria de tributação, no que se reconhece como "processo fiscal eqüitativo"47.

A própria OCDE elaborou algumas propostas para melhorar as relações entre fisco e contribuinte ${ }^{48}$, justificando que a crescente colaboração entre eles beneficia todos os envolvidos. De acordo com a OCDE, a relação entre fisco e contribuinte caracteriza-se como uma relação obrigacional decorrente de lei: obrigação de pagar tributos (obrigação principal) e obrigação de apresentar informações por meio das declarações periódicas (obrigação acessória). As informações transmitidas pelo contribuinte ao fisco serão por este utilizadas para verificar se o tributo efetivamente pago corresponde ao tributo devido. Por tal razão, os contribuintes, por vezes, relutam em fornecer tais informações ao fisco.

No entanto, a obtenção destas informações é fundamental para a tarefa do fisco de

\footnotetext{
${ }^{45}$ DACOMO, Natalia de Nardi. Direito Tributário participativo: transação e arbitragem administrativas da obrigação tributária. Tese (Doutorado em Direito), Faculdade de Direito da Pontifícia Universidade Católica de São Paulo, 2008, p. 16.

${ }^{46}$ VELDE, Elly Van de. Tax “arrangements" between the tax administration and the taxpayer: the legal limits, legal qualification and legal consequences. Sumário da tese (Doutorado em Direito), Universidade da Antuérpia, Bélgica. Sumário apresentado à Associação Européia de Professores de Direito Tributário (“European Association of Tax Law Professors - EATLP”).

47 TORRES, Ricardo Lobo Torres. Transação, conciliação e processo tributário administrativo equitativo. In: SARAIVA FILHO, Oswaldo Othon de Pontes; GUIMARÃES, Vasco Branco (Org.). Transação e Arbitragem no Ámbito Tributário. Belo Horizonte: Fórum, 2008, p. 93-95. Como bem pontua o ilustre professor da Universidade Estadual do Rio de Janeiro: "O processo tributário administrativo equitativo afirma-se no seio de uma ampla processualidade fiscal afastada de pressupostos autoritários. Superam-se os velhos esquemas da processualidade tributária [...]. Esse esquema simplista é incapaz de apreender a complexa conflitualidade desenvolvida entre o fisco e os contribuintes no Estado Democrático de Direito, que exige participação e o consenso."

48 OECD, Study into the role of tax intermediaries, 2008. Disponível em: <http://www.oecd.org/ dataoecd/28/34/ 39882938.pdf>. Acesso em: 9 mar. 2013.
} 
fiscalização. Quanto mais informações nas mãos da Administração, melhor será a alocação de recursos para aquelas atividades consideradas primordiais. Assim, tem-se, de um lado, as autoridades fazendárias, que buscam uma maior transparência e a divulgação espontânea de informações relevantes; de outro, os contribuintes, que objetivam uma maior segurança jurídica e a resolução de eventuais controvérsias o mais rapidamente possível. Deste modo, a melhora das relações termina por beneficiar todos os envolvidos.

Outra iniciativa com o objetivo de estreitar as relações entre fisco e contribuinte foi a criação de estatutos de defesa do contribuinte ${ }^{49}$. O objetivo desses documentos é tornar mais transparente a atuação físcal, evitando abusos por parte de seus funcionários. Em geral, esses estatutos explicitam as garantias do contribuinte perante o físco ${ }^{50}$. São exemplos de direitos assegurados aos contribuintes: a presunção de boa-fé, o direito a ser tratado com urbanidade pelos funcionários da Administração, o direito de obter informações e ser ouvido pela Administração, o direito a obter esclarecimentos sobre a forma correta de interpretação e aplicação das normas jurídicas tributárias.

Demais disso, alguns países criaram canais dentro da própria Administração tributária (ou numa estrutura paralela) responsáveis por auxiliar o contribuinte a resolver reclamações envolvendo o fissco: é o caso da figura do ombudsperson ou ouvidor. Muitas vezes, para evitar influências ou pressões, essa figura sequer se encontra no âmbito da Administração tributária ${ }^{51}$. O Brasil adotou essa prática e atualmente existem canais permitindo que o contribuinte leve a efeito reclamações em relação ao físco. Isso pode se dar, no âmbito federal, perante a Receita Federal do Brasil (RFB) ou, alternativamente, perante a Ouvidoria-Geral vinculada diretamente ao Ministério da Fazenda ${ }^{52}$.

Já o incremento das denominadas auto-declarações e o aumento das obrigações

\footnotetext{
49 Nesse sentido, o Ministério do Orçamento e Reforma do Estado francês publicou, em 2005, a Cartilha do Contribuinte (Chartre $d u$ Contribuable). Disponível em <http://www2.impots.gouv.fr/documentation/ charte_contrib/charte.pdf $>$. Acesso em: 10 out. 2012.

${ }^{50}$ Muitos são os casos de estatutos de defesa do contribuinte no mundo. É o caso, como bem pontuado por Ricardo Lobo Torres, nos Estados Unidos, do Taxpayer Bill of Rights II (1996), complementado pelo Taxpayer Bill of Rights III (2003); na Espanha, da Ley de Derechos y Garantias de los Contribuyentes $L D G C n^{\circ} 1 / 1998$; na Itália, do Estatuto dos Direitos do Contribuinte Italiano. (TORRES, Ricardo Lobo. Transação, conciliação e processo tributário administrativo equitativo. In: SARAIVA FILHO, Oswaldo Othon de Pontes; GUIMARÃES, Vasco Branco (Org.). Transação e arbitragem no âmbito tributário. Belo Horizonte: Fórum, 2008, p. 99).

${ }^{51}$ Segundo Richard K. Gordon, ainda em 1996, Austrália, Áustria, Dinamarca, França e Estados Unidos possuíam a figura do ombusdperson. (GORDON, Richard. K. Law of Tax Administration and Procedure. In: THURONYI, Victor. Tax Law Design and Draft, Washigton D.C.: International Monetary Fund, Vol. 1, 1996, p. 110).

${ }^{52}$ Para maiores informações acerca da Ouvidoria-Geral do Ministério da Fazenda: <http://www.fazenda. gov.br>.
} 
acessórias do contribuinte perante o fisco, não raras vezes, vem acompanhado de um auxílio da Administração tributária no cumprimento dessas obrigações. Nesse sentido, é comum a existência em sítios eletrônicos das denominadas "perguntas e respostas" (também conhecidas pela sigla FAQ, da expressão em língua inglesa frequently asked questions), que se destinam a esclarecer as dúvidas dos contribuintes para o cumprimento de seus deveres fiscais. A Administração transfere parte da sua obrigação de fiscalizar ao contribuinte, mas auxilia este a realizar a sua tarefa.

Ademais, como bem ressaltado por Michel Bouvier, um outro exemplo de iniciativa para melhorar o relacionamento entre fisco e a sociedade consiste na realização de jornadas de portas abertas (journées portes ouvertes ${ }^{53}$ ). Durante estas ocasiões a Administração tem a oportunidade de mostrar como funciona o trabalho da respectiva repartição, além de promover a conscientização da população acerca da importância do imposto como forma de financiamento dos serviços estatais, que tem por consequência o incentivo ao pagamento espontâneo dos tributos e luta contra a fraude e evasão fiscal ${ }^{54}$.

Em suma, as iniciativas vistas acima evidenciam a busca, pela Administração fiscal, de uma maior aceitação da tributação pelos cidadãos, numa tentativa de reabilitação da denominada "cidadania fiscal". Isso porque, nos dias atuais, a legitimidade da tributação não mais se justifica tão somente pelo consentimento do tributo pelo povo ou seus representantes, mas também pelas várias práticas administrativas ${ }^{55}$. Nesse contexto, a eficiência na gestão administrativo-tributária e o estreitamento das relações entre fisco e contribuinte tem papel fundamental para a efetividade da tributação.

\subsection{Os novos rumos: o contratualismo fiscal}

O "contratualismo fiscal" é citado como uma tendência do Direito Tributário contemporâneo, reflexo de uma mudança de paradigma na relação fisco-contribuinte ${ }^{56}$. Esse termo, às vezes impróprio do ponto de vista técnico, já que nem todos os exemplos de "contratualismo fiscal" possuem natureza jurídica de contratos propriamente ditos, visa a designar as situações nas quais o contribuinte e Administração fiscal estabelecem uma

\footnotetext{
${ }^{53}$ BOUVIER, Michel. Introduction au droit fiscal général et à la théorie de l'impôt. Paris: L.G.D.F., 2012, p. $220-221$.

54 Essa também é a finalidade do Programa Nacional de Educação Fiscal (PNEF). Acerca do programa, conferir : <http://www.esaf.fazenda.gov.br>.

${ }^{55}$ BOUVIER, Michel. op. cit., p. 175-176.

${ }^{56}$ LAMARQUE, Jean; NÉGRIN, Olivier; AYRAULT, Ludovic. Droit fiscal général. Paris: LexisNexis, 2011, p. 436.
} 
relação, menos hierarquizada e mais negocial.

A importância desse tema para o desenvolvimento do trabalho é evidente, já que, como se verá mais adiante, a transação em matéria tributária se insere entre as formas de “contratualismo fiscal", cujo objetivo é colocar fim a um litígio existente entre as partes. Assim, a análise da possibilidade de contratualismo fiscal é pressuposto para se enfrentar a questão da transação em matéria tributária.

\subsubsection{Discussão acerca dos "contratos fiscais"}

A questão da possibilidade de celebração de contratos fiscais pela Administração tem como pano de fundo antiga discussão em torno dos contratos administrativos. Se, antes, a contratação pelo Poder Público em matéria administrativa era discutível, tendo em vista o caráter soberano do Estado e a possibilidade de edição de atos de autoridade imperativos para consecução de seus objetivos sem qualquer participação do administrado (os denominados “atos administrativos"), essa idéia foi pouco a pouco sendo superada ${ }^{57}$.

Com a ampliação das funções estatais e a escassez de recursos para satisfazê-las, o Estado passou a incentivar a colaboração dos particulares para a consecução de suas atividades, abrindo mão de parte de suas prerrogativas de ente soberano e buscando uma relação menos hierarquizada com os cidadãos. Segundo José Casalta Nabais, os contratos administrativos, ainda que com características próprias distintas em relação aos contratos de Direito Privado ${ }^{58}$, somente foram aceitos em razão dessa mudança de paradigma do Estado: de uma concepção liberal para uma concepção social ${ }^{59}$.

O contrato administrativo é apenas uma das espécies do gênero contrato público, que abrangeria todas as obrigações resultantes de um acordo de vontades, envolvendo

\footnotetext{
${ }^{57}$ NABAIS, José Casalta. Contratos Fiscais: reflexões acerca da sua admissibilidade. Coimbra: Coimbra, 1994, p. 137 et seq.

${ }^{58}$ A esse respeito, vale destacar que, até o começo do século passado, vários eram os autores que negavam aceitação aos contratos administrativos. Entre estes, dividiam-se, de um lado, aqueles que entendiam que a Administração Pública somente poderia editar atos administrativos e figuras análogas, com fundamento em seu ius imperium, obrigando unilateralmente seus administrados; e, de outro lado, aqueles que entendiam que os contratos celebrados pela Administração eram, em realidade, contratos de natureza privada, onde a Administração renunciava às prerrogativas que lhe eram outorgadas em relação a sua qualidade de poder estatal. Várias eram as razões destacadas pela doutrina para a não aceitação dos contratos administrativos, destacando-se: (a) a desigualdade entre Administração e particulares; (b) a suposta ausência de autonomia da vontade da Administração; (c) a incompatibilidade do contrato administrativo com o princípio da legalidade; (d) a rigidez de um contrato administrativo e a constante mutabilidade do interesse público. Para uma análise detalhada desses argumentos, recomenda-se a leitura de José Casalta Nabais. (Ibid., p. 22 et seq).

${ }^{59}$ Ibid., p. 17 e 104 et seq.
} 
interesses públicos, em que o Estado faça parte. De acordo com Edmir Netto de Araújo, ao lado dos contratos administrativos, há outras modalidades de contratos de Direito Público que poderiam também ser celebrados pela Administração: contratos de direito constitucional, internacional e tributário (ramos do Direito Público) ${ }^{60}$. Para alguns desses outros tipos de contratos, a controvérsia persiste.

Com efeito, embora para a matéria administrativa, a possibilidade de contratar com o Estado seja hoje uma realidade incontestável, permanece a discussão, na atualidade, em muitos países, inclusive no Brasil, acerca da possibilidade de a Administração celebrar contratos fiscais, isto é, contratos que tenham por objeto matéria tributária.

Um dos argumentos utilizados para se negar a possibilidade de contratualismo fiscal é que o princípio da legalidade tributária vedaria o contrato como fonte de obrigações fiscais para os contribuintes. Isso porque, sendo o tributo tradicionalmente considerado como uma prestação pecuniária que tem sua origem na lei, não se admitiria sua criação ou extinção por contrato ${ }^{61}$. Em outras palavras, considerando que a lei tributária é uma norma de ordem pública, não poderia ela ser derrogada por dispositivos de natureza contratual ${ }^{62}$.

Outro argumento para se negar a possibilidade de se celebrar contrato em matéria tributária com a Administração decorre da aplicação dos princípios da capacidade contributiva e igualdade. É que, cabendo aos cidadãos o financiamento das atividades estatais conforme as suas respectivas possibilidades materiais, não poderia a Administração, por contrato, frustrar tais princípios celebrando com alguns deles acordos que viessem porventura a modificar os critérios definidos em lei para a sua participação nas despesas da coletividade ${ }^{63}$.

\footnotetext{
${ }^{60}$ ARAÚJO, Edmir Netto de. Curso de Direito Administrativo. São Paulo: Saraiva, 2010. p. 665.

${ }^{61}$ Segundo o art. $3^{\circ}$, do CTN: "Tributo é toda prestação pecuniária compulsória, em moeda ou cujo valor nela se possa exprimir, que não constitua sanção de ato ilícito, instituída em lei e cobrada mediante atividade administrativa plenamente vinculada".

${ }^{62}$ Nesse sentido Jean Lamarque afirma que tributação é matéria de ordem pública e a situação do contribuinte não pode, em princípio, ser modificada por contrato. No original: "Le statut du contribuable ne peut être modifié par voie conventionnelle. Particulièrement bien établie, cette solution de principe a été affirmée pour la première fois par la Cour de cassation 'la perception des impôts intéresse essentiellement l'ordre public et ne peut donc pas être la matière d'un contrat' passé entre le contribuable et le fisc (Cass. Civ. 13 mars 1895, Dreyfus Frères et Cie: S 1895, I, p. 465, note A. Wahl)" Trecho extraído da obra: LAMARQUE, Jean; NÉGRIN, Olivier; AYRAULT, Ludovic. Droit Fiscal Général. Paris: Lexis Nexis, 2011, p. 435.

${ }^{63}$ Nesse sentido era a opinião da doutrina majoritária francesa no século passado. A esse respeito, Jacques Chevallier entendia que "il serait d'ailleurs contraire aux principes du droit français qu'un droit régalien
} 
No entanto, dadas as peculiaridades do Direito Tributário contemporâneo, caracterizado por uma maior interação entre contribuinte e fisco, a idéia de vedação de celebração de contratos em matéria tributária está sendo pouco a pouco atenuada. Prova disso é que o próprio Conseil d'État francês, recentemente, divulgou um relatório dando conta da possibilidade de contratualização das relações jurídicas no âmbito do direito fiscal, corroborando para a superação da posição doutrinária em sentido contrário ${ }^{64}$.

A possibilidade de contratualismo fiscal está representada por diversos institutos existentes na atualidade. Esses institutos, não obstante a diversidade de nomenclatura que recebe em seus respectivos ordenamentos jurídicos, possuem um pressuposto em comum, qual seja: a possibilidade de negociação entre a autoridade fiscal e o contribuinte de certos aspectos da matéria tributária. Mas, também é fato que, examinados mais a fundo, nem todos os instrumentos tidos como "contratos fiscais" possuem natureza jurídica de contratos propriamente dito.

José Casalta Nabais distingue duas categorias de contratos fiscais: (a) os falsos contratos fiscais que podem, por sua vez, serem subdivididos em (a1) contratos de mera incidência: isto é, contratos celebrados entre particulares ou entre estes e a Administração com meros reflexos fiscais ${ }^{65}$; (a2) contratos fiscais aparentes: em que haveria uma forma de colaboração estreita entre a Administração e o contribuinte pela busca de um consenso que resulta não em contratos propriamente ditos, mas em atos unilaterais ${ }^{66}$; e (b) os

comme celui de lever l'impôt puisse être limité par des stipulations contractuelles". (CHEVALLIER, Jacques. Les formes actuelles de l'économie concertée. Disponível em: <http://www.upicardie.fr/labo/curapp/revues/root/ 1/chevallier.pdf $>$. Acesso em: 23 out. 2012).

${ }^{64}$ De acordo com o relatório Le contrat, mode d'action publique et de production de normes, a evolução do Direito Tributário nos últimos anos deixa transparecer uma possibilidade crescente de estabelecer relações jurídicas negociais entre Administração fiscal e o contribuinte. Entretanto, ao mesmo tempo em que louva tal iniciativa, lamenta a tímida aparição, até o momento, do instituto contratual no Direito Tributário francês. (FRANÇA. Le contrat, mode d'action publique et de production de normes. CE, EDCE, n. 59, 2008, p. 66).

${ }^{65}$ Diz-se contratos de mera incidência, pois são contratos que não interferem no nascimento, manutenção, modificação ou extinção da obrigação tributária principal (pagar o tributo), nem em relação às obrigações acessórias (deveres instrumentais ou formais). Nessa hipótese, o contrato celebrado entre os particulares ou entre o particular e a Administração serve tão somente de fundamento fático para a incidência tributária prevista em lei. É o caso, por exemplo, do contrato de compra e venda entre as partes, que dá ensejo à incidência do imposto sobre transmissão intervivos (ITBI); e do contrato de doação, que dá ensejo ao imposto sobre transmissão de bens causa mortis ou doação (ITCMD). (NABAIS, José Casalta Nabais. Contratos Fiscais: reflexões acerca da sua admissibilidade. Coimbra: Coimbra, 1994, p. 89 et seq).

${ }^{66}$ É o caso do método forfaitaire, que já foi bastante utilizado no direito francês e perdeu importância nos últimos anos. De acordo com esse método, com base nos rendimentos e outros elementos de um determinado contribuinte (e.g. despesas, margem de lucro, etc.), a Administração fiscal elabora uma proposta de tributação diferenciada (e.g. percentual da renda bruta ou rendimento médio por hectare), que poderá ser aceita ou não por este. Este regime, embora de certa forma se assemelhe com a hipótese do lucro presumido, previsto na legislação nacional (Lei $n^{\circ} 9.249 / 95$ ), onde se estabelece uma base de cálculo de IRPJ e CSLL calculada em conformidade com o percentual da receita bruta do contribuinte, dele diferencia- 
verdadeiros contratos fiscais, que podem, por sua vez, ser subdivididos em (b1) contratos relativos à determinação da matéria tributável: cujo o objeto é o próprio lançamento do tributo e seus acessórios (é o caso da transação) ${ }^{67}$; (b2) contratos relativos à cobrança de tributos: em que se transfere as atribuições de arrecadação a um terceiro; e (b3) contratos relativos a beneficios fiscais: que outorgam vantagens fiscais.

Há, no entanto, quem continue sustentando que as hipóteses de "contratualismo fiscal" entre Administração tributária e contribuinte são bastante reduzidas ${ }^{68}$. É que, muitos dos exemplos citados pela doutrina de supostos contratos fiscais, em realidade, não passariam de hipóteses de atos unilaterais em que se permite a participação do administrado. Isso porque, esses mecanismos, embora condicionados à aceitação dos contribuintes para gerar efeitos, seriam, de fato, decididos de forma unilateral pela Administração. Por essa razão, não haveria que se falar em "contrato" propriamente dito.

Para Jean Lamarque, a verdadeira relação contratual entre fisco e contribuinte pressupõe a presença de, ao menos, duas condições: (a) que a relação jurídica decorra de um ato que resulte de uma negociação prévia das partes; e (b) que as obrigações resultantes desse ato se aperfeiçoem a partir da conclusão formal do ato, não estando condicionadas à execução dos compromissos pela parte contrária (como acontece em alguns atos unilaterais). Assim, para o autor francês, algumas hipóteses mencionadas pela doutrina como sendo hipóteses de contratos fiscais não seriam efetivamente contratos, mas atos unilaterais que comportam compromissos de ambas as partes ${ }^{69}$.

A existência de um verdadeiro contrato fiscal, nessa hipótese, é bastante discutível na doutrina. Por conta da controvérsia acerca do caráter contratual ou não de alguns desses institutos, Elly Van de Velde preferiu tratá-los como "mecanismos" ou "estruturas" tributárias entre a Administração fiscal e o contribuinte ("tax 'arrangements' between the

se, pois que, no regime forfaitaire francês, o rendimento tributável é fixado pela Administração fiscal ou por uma comissão composta também por representantes dos contribuintes, ao passo que no regime brasileiro do lucro presumido, este seria um regime opcional previsto na própria legislação. Para uma análise detalhada da tributação pelo lucro presumido, conferir HIGUCHI, Hiromi; HIGUCHI, Fábio Hiroshi; HIGUCHI, Celso Hiroyuki. Imposto de Renda das Empresas, São Paulo: IR Publicações Ltda., 2013, p. 51 et seq.

${ }^{67}$ Esse seria o caso também do instituto da "avença" previsto no ordenamento jurídico-tributário português. Esse instituto admite que fisco e contribuinte, por acordo, estabeleçam, antecipadamente, o valor da obrigação tributária que seria devida caso houvesse a apuração normal dos tributos. O objetivo desse instituto, aplicável principalmente em relação a alguns tributos específicos e algumas atividades, é simplificar o regime tributário e, ao mesmo tempo, reduzir a necessidade de fiscalizações complexas e custosas pela Administração tributária.

68 LAMARQUE, Jean; NÉGRIN, Olivier; AYRAULT, Ludovic. Droit Fiscal Général, Paris: Lexis Nexis, 2011, p. 436-437.

${ }^{69}$ Ibid., p. 437-438. Vale destacar, no entanto, que o referido autor reconhece expressamente que a transação fiscal no Direito francês tem natureza contratual. 
tax administration and the taxpayer") ${ }^{70}$. Seja como for, fato é que, atualmente, vários desses institutos encontram previsão expressa em determinados ordenamentos jurídicos, como é caso do português ${ }^{71}$.

Em resumo, ainda que se negue a natureza jurídica contratual de alguns desses institutos, haja vista que nem todos possuem todas as características de uma relação tipicamente contratual, parece incontroversa a existência de mecanismos nos quais se verifica a possibilidade de negociação de matéria tributária, ou de contratos fiscais lato sensu. Esses instrumentos são o resultado de uma tendência do direito físcal contemporâneo de busca pela eficiência na gestão administrativo-tributária e do estreitamento das relações entre fisco e contribuinte.

\subsubsection{Instrumentos de contratualismo fiscal}

Conforme antecipado, a experiência em diversos países demonstra a existência de vários instrumentos, senão de contratualismo em matéria tributária stricto sensu, ao menos de mecanismos de contratualismo lato sensu, em que se admite a participação dos contribuintes e, por vezes, até mesmo, uma certa negociação destes com a Administração tributária. Serão analisados a seguir apenas alguns desses instrumentos que, pela sua relevância e particularidades, merecem destaque.

\subsubsection{Consultas e Advance Tax Ruling}

As consultas fiscais, conhecidas, no direito estrangeiro pelo termo inglês advance tax rulings, ou simplesmente "rulings",

\footnotetext{
${ }^{70}$ VELDE, Elly van de. Tax 'arrangements' between the tax administration and the taxpayer: the legal limits, legal qualification and legal consequences. Sumário da tese (Doutorado em Direito), Universidade da Antuérpia, Bélgica. Sumário apresentado à Associação Européia de Professores de Direito Tributário (“European Association of Tax Law Professors - EATLP").

${ }^{71}$ De acordo com o art. 37..$^{\circ}$ da LGT portuguesa (aprovada pelo Decreto-lei n. ${ }^{0}$ 398/98): "1 - Caso os benefícios fiscais sejam constituídos por contrato fiscal, a tributação depende da sua caducidade ou resolução nos termos previstos na lei. 2 - A lei pode prever que outros contratos sejam celebrados entre a Administração e o contribuinte, sempre com respeito pelos princípios da legalidade, da igualdade, da boa fé e da indisponibilidade do crédito tributário." Assim, a legislação lusitana permite a concessão, por meio de contratos celebrados com os contribuintes, de benefícios fiscais aos projetos de investimento. Para tanto, todavia, é necessário que os referidos investimentos estejam relacionados a determinadas atividades econômicas previamente estabelecidas em lei, bem como que o montante do investimento seja considerável. Tal previsão tem por finalidade, ao mesmo tempo, incentivar o investimento estrangeiro e permitir que a Administração possa decidir se e quanto de incentivo fiscal deve ser concedido ao particular, tendo como referência a expectativa de benefícios econômicos e sociais que serão gerados.

${ }^{72}$ A consulta fiscal prevista no direito brasileiro confunde-se com o ruling do direito estrangeiro. Tanto isso é verdade que no Relatório brasileiro do Congresso anual da IFA (1999), os relatores nacionais do Congresso trataram do instituto da consulta no tópico sobre advance rulings. Advance Rulings. In: Cahiers
} 
romano, de acordo com o qual os imperadores romanos forneciam respostas escritas ou orais a questões a ele submetidas ${ }^{73}$. Esse instituto evoluiu consideravelmente ao longo dos anos, de tal forma que, na atualidade, há previsão de consultas fiscais ou rulings na legislação tributária de diversos países ${ }^{74}$.

De fato, estes são instrumentos importantes para a interpretação da lei tributária. Consistem em decisões unilaterais, fornecidas pela Administração tributária, a pedido de um contribuinte específico, que contém um esclarecimento ou uma orientação em relação à situação fiscal deste contribuinte ou de um grupo de contribuintes $^{75}$. Esse posicionamento do fisco abrange, em geral, tão somente transações futuras e deverá ser respeitado pelos agentes da Administração tributária quando de eventual fiscalização.

As consultas/rulings não possuem a natureza típica de contratos, e por isso, identificam-se no gênero contratualização, como forma ampla de entender os mecanismos negociais que dispõem contribuinte e fisco, mas não na espécie de contratos fiscais propriamente ditos. Tratam-se, em verdade, de decisões unilaterais da Administração sobre uma dúvida do contribuinte; uma instrução aplicada a um caso concreto.

De acordo com Frans Vanistendael ${ }^{76}$, o objetivo principal de uma consulta ou ruling é evitar conflitos e reduzir a litigância administrativa ou judicial entre fisco e contribuinte $^{77}$. A redução da litigância, bem como dos custos e tempo a ela relacionados, é de droit fiscal internacional. Netherlands, Vol. LXXXIVb, 1999, p. 267-279.

${ }^{73}$ ROMANO, Carlo. Advance Tax Rulings and Principles of Law: Towards a European Tax Ruling System? - Volume 4 in the Doctoral Series. IBFD, 2002, p. 5-8.

${ }^{74}$ Sobre os países que adotam o ruling, conferir J. ELLIS, Maarten. General Report, Advance Rulings. In: Cahiers de droit fiscal internacional. Netherlands, Vol. LXXXIVb, 1999. Sobre o ruling (também conhecido como interpello) na Itália, conferir BUSA, Vincenzo. Gli instituti deflativi del contenzioso nell'esperienza italiana: a experiência italiana sobre transação e conciliação em matéria tributária e demais modalidades alternativas de solução de controvérsias fiscais. In: TÔRRES, Heleno Taveira (Coord.). Direito Tributário Internacional Aplicado Volume V, São Paulo: Quartier Latin, 2008, p. 541 et seq.

${ }^{75}$ Maarten J. Ellis destaca que o ruling pode ser definido como: "A more or less binding statement from the Revenue authorities upon the voluntary request of a private person, concerning the treatment and consequences of one or a series of contemplated future actions or transactions". Em conformidade com essa concepção, estão excluídos da definição de ruling os seguintes pronunciamentos: a) os acordos relativos a transações/operações passadas que não se refiram ao futuro; b) os denominados public rulings, quer dizer, instruções gerais expedidas pelas autoridades fazendárias expressando sua interpretação em relação à legislação, mesmo que não solicitada por um contribuinte em particular nem se referindo a uma situação individual do contribuinte; e c) as solicitações de tratamento tributário especial que são outorgadas a pedido do contribuinte que preencha determinadas condições previamente estabelecidas pela legislação. (J. ELLIS, Maarten. General Report, Advance Rulings. In: Cahiers de droit fiscal internacional. Netherlands, Vol. LXXXIVb, 1999, p. 21).

${ }^{76}$ VANISTENDAEL, Frans. Legal Framework for Taxation. In: THURONYI, Victor. Tax Law Design and Drafting, Washington D.C.: International Monetary Fund, 1996, p. 61.

${ }^{77}$ Citando o relatório emitido pela Comissão Carter no Canadá (1967), Marteen J. Ellis ressalta, ainda, uma série de outras vantagens do ruling, entre elas: a possibilidade de melhora das relações entre o fisco e o público em geral; a garantia de uma maior certeza do tratamento tributário de suas transações; uma maior 
uma de suas grandes vantagens ${ }^{78}$. Para tanto, requer-se uma apreciação prévia da situação jurídica do contribuinte pela Administração, que fornecerá sua interpretação da lei tributária. Com isso, o contribuinte terá uma maior segurança em relação ao tratamento tributário de suas operações, posto que os agentes do físco estarão vinculados à interpretação fornecida ("binding effects of tax rulings").

No entanto o efeito vinculante da interpretação dada pela fisco está condicionado à que o contribuinte revele todos os fatos relevantes. O contribuinte não poderá exigir que o fisco se atenha à interpretação anteriormente dada quando omitiu ou distorceu algum fato importante em relação à sua operação. Como bem pontua Marteen J. Ellis, a validade da resposta da Administração fiscal é condicionada à apresentação de informações completas e verídicas pelo requerente, "permitindo que as discussões que se seguem se dêem com um caráter aberto e informado e seja quase como uma 'negociação comercial"'79.

Se por um lado a entrega de informações completas permite que o contribuinte possa opor o posicionamento manifestado pelo fisco a seus próprios agentes, concedendo maior certeza e segurança em relação ao tratamento tributário de suas operações, por outro lado, é exatamente nessa abertura de informações que reside uma das grandes desvantagens do procedimento. É que, já tendo o contribuinte prestado informações detalhadas de suas operações, caso a decisão da consulta/ruling seja desfavorável, isso o colocará em uma posição vulnerável perante o fisco, aumentando o risco de fiscalização. Daí porque muitos contribuintes relutam em utilizar o instituto.

Demais disso, verifica-se que em alguns países a consulta/ruling foi adotada não com o intuito de garantir maior segurança jurídica aos contribuintes, nem para eliminar ou reduzir a litigância entre fisco e contribuinte, mas sim com objetivo diverso. É o caso, por exemplo, dos Países Baixos. Lá, a consulta/ruling foi adotada para atrair investimentos estrangeiros. Permite-se que a autoridade fiscal faça concessões às empresas que realizem atividades em seu território. A utilização com essa finalidade tem sido objeto das mais variadas críticas tanto da OCDE como da Comissão da União Européia, notadamente

consistência à aplicação da lei tributária pela Administração tributária. (J. ELLIS, Maarten. General Report, Advance Rulings. In: Cahiers de droit fiscal internacional. Netherlands, Vol. LXXXIVb, 1999, p. 24).

${ }^{78}$ Marteen J. Ellis relativiza o caráter redutor de controvérsias do ruling. Destaca ser verdade que o ruling, quando favorável ao contribuinte, previne a litigância e reduz a controvérsia. No entanto, pondera que considerando que normalmente cabe recurso da decisão, quando esta for desfavorável ao contribuinte, ele dará ensejo a uma maior litigância. Isso, porém não é de todo verdade, pois que, em muitos casos, diante de uma decisão desfavorável, o contribuinte poderá buscar outros meios de realizar o que pretendido, ou deixar de fazê-lo. Em ambos os casos, a litigância é evitada. (Ibid., p. 26).

${ }^{79}$ Ibid., p. 24. 
quando a decisão concessória ou denegatória não goza de transparência ${ }^{80}$.

No Brasil, a consulta tributária surgiu para evitar que o contribuinte que tivesse dúvidas em relação à aplicação de determinada norma tributária à sua situação particular ficasse sujeito a penalidades pelo descumprimento de sua obrigação tributária, enquanto pendente manifestação do fisco a respeito. Encontra previsão no art. 161, $\S 2^{\circ}$ do $\mathrm{CTN}^{81}$. Em âmbito federal, sua regulamentação passou por diversas alterações ${ }^{82}$. Atualmente, a consulta encontra-se disciplinada no Decreto $n^{\circ} 70.235 / 72$ e na Lei $n^{\circ}$ 9.430/96.

De acordo com a regulamentação vigente, a consulta formulada pelo devedor dentro do prazo para pagamento do tributo, enquanto pendente, obsta a cobrança de juros moratórios, a imposição de penalidades ou a aplicação de medidas de garantia. Trata-se, como bem pontuado por Ruy Barbosa Nogueira, de um instrumento de harmonia fiscal ${ }^{83}$.

Em resumo, apesar de possuir algumas desvantagens, a consulta/ruling é considerada um instrumento benéfico ao contribuinte, já que garante uma maior segurança nas relações com o fisco. Além do mais, o procedimento termina por reduzir a litigiosidade, pois que já se estabelece de antemão as consequências tributárias de determinada operação. Enfim, a consulta/ruling permite uma relação fisco-contribuinte mais aberta e direta ${ }^{84}$, traduzindo-se num mecanismo de colaboração entre ambos.

Finalmente, as consultas e os rulings diferem de mecanismos previstos na legislação de alguns países para conceder um tratamento diferenciado ao contribuinte. É o caso dos agréments fiscaux, existentes no direito francês, que serão estudados a seguir.

\subsubsection{Os Agréments fiscaux do direito francês}

$\mathrm{Na}$ França, os denominados agréments fiscaux surgiram a partir da segunda

\footnotetext{
80 J. ELLIS, Maarten. General Report, Advance Rulings. In: Cahiers de droit fiscal internacional. Netherlands, Vol. LXXXIVb, 1999, p. 27.

${ }^{81}$ Art. 161. O crédito não integralmente pago no vencimento é acrescido de juros de mora, seja qual for o motivo determinante da falta, sem prejuízo da imposição das penalidades cabíveis e da aplicação de quaisquer medidas de garantia previstas nesta Lei ou em lei tributária (...) $\S 2^{\circ} \mathrm{O}$ disposto neste artigo não se aplica na pendência de consulta formulada pelo devedor dentro do prazo legal para pagamento do crédito (grifos acrescidos).

82 Vários foram os atos normativos que regulamentaram a matéria, podendo ser citados, a título exemplificativo, a Instrução Normativa $\mathrm{n}^{\circ} 26$, de 25 de maio de 1970, posteriormente revogada pela Instrução Normativa ${ }^{\circ}$ 2, de 9 de janeiro de 1997, por sua vez, revogada pela Instrução Normativa $\mathrm{n}^{\circ} 230$, de 25 de outubro de 2002. Atualmente, está em vigor a Instrução Normativa nº 740, de 2 de maio de 2007.

${ }^{83}$ NOGUEIRA, Ruy Barbosa. Curso de Direito Tributário. São Paulo: Saraiva, 1994, p. 255.

${ }^{84}$ INTERNATIONAL MONETARY FUND. Tax Law Note: Should Taxpayers Be Able to Obtain Binding Advance Rulings? Disponível em: <http://www.imf.org/external/np/leg/tlaw/2004/notes/eng/advan.htm.> Acesso em: 25 out. 2012.
} 
metade do século $\mathrm{XX}^{85}$. Consistiam na outorga de benefícios fiscais a certos agentes econômicos em troca do cumprimento por estes de determinados objetivos privilegiados pelo Estado. Esses objetivos eram normalmente previstos no plano de desenvolvimento econômico e social. Os agréments fiscaux caracterizam-se, portanto, como mecanismos de incitação. Incitam as empresas a se comportarem de determinada forma, privilegiada pelo Estado, em troca de vantagens fiscais ${ }^{86}$.

O agrément fiscal pode ser visto como uma alternativa à incitação econômica por intermédio de subvenções e demais ajudas financeiras. Ele autoriza a aplicação de um regime fiscal específico aos contribuintes que realizam determinadas atividades ou operações. Trata-se de um regime fiscal "derrogatório" da legislação tributária normalmente aplicável à hipótese (régime fiscal dérogatoire du droit commun), que pode ser outorgado em situações onde o contribuinte pratique determinadas operações ou atividades estabelecidas pela legislação como sendo de interesse do Estado ${ }^{87}$.

Essas operações ou atividades privilegiadas pela legislação desenvolvem-se normalmente em setores importantes da economia. É o caso, por exemplo, do desenvolvimento regional, da promoção das exportações ou de incentivo às pesquisas científicas e técnicas. De acordo com José Casalta Nabais, três seriam os principais objetivos a serem atingidos por esses instrumentos de incitação econômica: (a) a melhora da situação concorrencial das empresas locais e a busca por mercados externos; (b) o

\footnotetext{
${ }^{85}$ Para José Casalta Nabais, os agréments fiscaux como modalidade de contrato fiscal surgiram mais exatamente no ano de 1948, num contexto de planificação flexível, onde os planos econômicos e sociais eram sobretudo indicativos. Essa expressão foi utilizada posteriormente quando do IV Plano de desenvolvimento econômico e social (1962-65), para exprimir "as técnicas directivas orientadas para o incitamento das empresas a adoptarem determinados comportamentos conformes aos objectivos de política econômica previstos no plano". (NABAIS, José Casalta. Contratos Fiscais: reflexões acerca da sua admissibilidade. Coimbra: Coimbra, 1994, p. 179 et seq). Para Jacques Chevalier, no entanto, embora as técnicas de redução e isenção de impostos já fossem bastante utilizadas no Direito Tributário, foi somente a partir do IV Plano que elas se transformaram em um mecanismo de incitação econômica baseada em um acordo celebrado entre os poderes públicos e as pessoas de Direito Privado. (CHEVALLIER, Jacques. Les formes actuelles de l'économie concertée. Disponível em: <http://www.u-picardie.fr/labo/curapp /revues/root/1/chevallier.pdf.> Acesso em: 11 nov. 2012, p. 106).

${ }^{86}$ De acordo com Jacques Chevalier, a caracterização do agrément fiscal como modalidade de contrato seria no mínimo duvidosa, pois que o contrato implica idéia de negociação entre o poder público e as empresas privadas, enquanto que o agrément em sentido estrito, resulta de um modo de elaboração sobretudo unilateral. O agrément é, na verdade, um pseudo-contrato. É que, sua observância dá ensejo à aplicação, pura e simplesmente, de um regime fiscal previsto em lei ou em regulamentos. Deve, portanto, ser considerado como um ato-condição (actes-conditions). (Ibid., p. 106 et seq).

${ }^{87}$ De acordo com o Précis de Fiscalité 2012, da Administração fiscal francesa: "Les agréments fiscaux sont des procédures administratives qui permettent à un contribuable de bénéficier d'un régime fiscal dérogatoire pour certaines opérations prévues par la loi. Leur obtention est subordonnée à une demande de l'intéressé et à une décision de l'autorité compétente". Disponível em: <http://www.impots.gouv.fr>. Acesso em: 07 set. 2012.
} 
desenvolvimento regional, a investigação científica, técnica e cultural; e (c) o favorecimento dos departamentos ultramarinos ${ }^{88}$.

Atualmente existem diversos dispositivos que regulamentam o instituto do agrément fiscal na França ${ }^{89}$. Estes dispositivos estão previstos num emaranhado de normas espalhadas pelo Código Geral de Impostos (CGI). No entanto, estas podem ser classificadas, de acordo com o objetivo pretendido pelo legislador, da seguinte forma: (1) agréments financeiros ${ }^{90}$; (2) agréments geográficos ${ }^{91}$; (3) agréments em favor da conservação do patrimônio artístico nacional ou do espaço territorial ${ }^{92}$; (4) agréments em favor da criação, da transmissão ou recuperação de empresas ${ }^{93}$; e (5) outros agréments $^{94}$.

O agrément fiscal é concedido por meio de uma decisão administrativa individual a pedido da pessoa interessada ${ }^{95}$. Há quem sustente, por essa razão, que o agrément não

\footnotetext{
${ }^{88}$ NABAIS, José Casalta. Contratos Fiscais: reflexões acerca da sua admissibilidade. Coimbra: Coimbra, 1994, p. 181.
}

${ }^{89}$ Jean Lamarque aponta que coexistiriam atualmente no Direito francês mais de 20 disposições que pressupõem a obtenção prévia de um agrément. Esse número, no entanto, já foi maior. No passado (1992), contavam-se mais de 34 disposições legislativas prevendo a possibilidade de agrément, conforme documentação de base DB13D1 da Administração tributária francesa. (LAMARQUE, Jean; NÉGRIN, Olivier; AYRAULT, Ludovic. Manuel Droit fiscal general, Paris: Lexis Nexis, 2011, p. 450).

${ }^{90}$ São exemplos da modalidade de agrément financeiro: (a) o regime do benefício mundial ou consolidado, previsto no art. 209, quinquies do CGI; (b) as operações de aporte parcial de ativos e de cisão, cujo regime de agrément está previsto nos arts 210 B-3 do CGI; (c) a compensação de prejuízos físcais de anos anteriores na hipótese de fusão ou operações similares, prevista no art. 209-II do CGI; e (d) a transferência de crédito tributário em face do Tesouro Nacional, prevista no art. 220 quinquies-II do CGI. Para melhor compreender o regime do benefício mundial ou consolidado, conferir CASTAGNĖDE, Bernard. Précis de Fiscalité International, Paris: PUF, 2010, p. 290-296. Esse regime, todavia, foi suprimido recentemente pela LFR 2011-1117 - Lei de Finanças Retificativa para 2011.

${ }^{91}$ Podem ser citados como exemplos da modalidade de agrément geográfico, aquelas em favor do desenvolvimento dos departamentos ultramarinos, tais como: (a) as isenções e reduções de imposto concedidas (défiscalisation) em favor dos investimentos realizados nos departamentos e coletividades francesas ultramarinas, conforme arts. 199, undecies A, 199 undecies $B$ et 217 undecies do CGI; (b) a isenção do imposto de renda das pessoas jurídicas (impôt sur les sociétés ) para criação de novas atividades, prevista no art. 208 quater do CGI; e (c) algumas medidas específicas concedidas em favor do desenvolvimento dos departamentos da Córsega, previstas no art. 44 decies, art. 1466 B e 1466C do CGI. A Córsega é uma ilha situada no mediterrâneo que faz parte do território francês, nela se encontrando dois de seus 101 departamentos: Haute Corse (2A) e Corse du Sud (2B).

${ }^{92}$ São exemplos da modalidade de agrément em favor da conservação do patrimônio artístico nacional ou do espaço territorial: (a) a isenção do imposto sobre doações de obras de arte de alto valor artístico e histórico ao Estado, previsto no art. 1131 do CGI; (b) a dação em pagamento, previsto no art. 1716 bis do CGI; (c) a possibilidade de dedução da renda global das despesas relacionadas a alguns imóveis, prevista no art. 156-II- $1^{\circ}$ ter do CGI; (d) subscrição de capital e amortização de ações das SOFICA (sociedades de financiamento de obras cinematográficas e audiovisuais, prevista no art. 199, unvicies e no art. 217 septies do CGI.

${ }^{93}$ Classifica-se como agrément em favor da criação, da transmissão ou recuperação de empresas a isenção concedida às sociedades criadas para a recuperação de empresas industriais em dificuldade, conforme previsto no art. 44 septies do CGI.

${ }^{94}$ É o caso das doações à entidades beneficentes (mécénat), prevista no art. 238 do CGI.

${ }^{95}$ Conforme informações obtidas no sítio da Administração tributária francesa. Disponível em: $<\mathrm{http}: / /$ www.impot.gouv.fr>. Acesso em: 12 nov. 2012. 
teria a natureza jurídica de contrato, mas sim de um ato administrativo unilateral ("ato condição"). Essa posição já teria sido manifestada pelo Conseil d'État francês em algumas oportunidades $^{96}$. Segundo esse entendimento, o fato do agrément implicar na assunção de compromissos por parte do contribuinte, e de que haja uma espécie de negociação entre este e o fisco, não teria qualquer reflexo sobre sua natureza de "ato-condição",97.

No entanto, como reconhece Jean Lamarque, ainda que o agrément tenha natureza jurídica de ato unilateral, o regime aplicável a este instituto jurídico, “comporta elementos que, do ponto de vista de suas consequências práticas, não são muito diferentes em seus efeitos daqueles que apresentariam um autêntico 'contrato fiscal"'98. É que, os agréments resultam de um processo de negociação das partes e podem acarretar uma série de direitos para o contribuinte, a depender de sua modalidade ${ }^{99}$, devendo ser observados pela Administração fiscal.

O procedimento para obtenção do agrément é composto de três etapas principais: pedido, instrução e decisão. Ele tem início a partir de um pedido da parte interessada que o entrega à um órgão da Administração. Recebido o pedido pela autoridade competente, tem início um diálogo entre as partes: é a etapa onde se dá a negociação. Posteriormente, com a formalização do pedido, o interessado assume o compromisso de realizar a operação descrita e cumprir as condições nele estipuladas. Segue-se a instrução do pedido que tem por objetivo (a) examinar se estão preenchidas todas as condições legais para sua concessão; e (b) a conveniência e a oportunidade do agrément, isto é, as vantagens econômicas oferecidas pelo contribuinte ${ }^{100}$, podendo, inclusive, serem consultados outros órgãos ${ }^{101}$. Finalmente, o agrément concedendo um regime fiscal diferenciado é outorgado

\footnotetext{
${ }^{96} \mathrm{CE} \mathrm{n}^{\mathrm{o}}$ 64509, Min. c/ Sté Samat (10.03.1967) ; e CE no 133411, Sté Nouvelle de Robinetterie Industrielle (06.07.1994).

${ }^{97}$ LAMARQUE, Jean; NÉGRIN, Olivier; AYRAULT, Ludovic. Manuel Droit fiscal général, Paris: Lexis Nexis, 2011, p. 451.

${ }^{98}$ No original: "Même regardé comme constitutif d'un acte unilatéral, le régime juridique de l'agrément comporte des éléments qui, sur le plan des conséquences pratiques, ne sont pas si éloignés dans leurs effets de ceux que pourrait présenter un authentique contrat fiscal".(Ibid., p. 451).

${ }^{99}$ A esse respeito, vide parágrafos subsequentes que tratam do agrément de pleno direito e do agrément discricionário.

${ }^{100}$ NABAIS, José Casalta. Contratos Fiscais: reflexões acerca da sua admissibilidade. Coimbra: Coimbra, 1994, p. 183-184. Para o autor, quando da instrução, caberia também à Administração examinar a oportunidade fiscal da concessão do agrément solicitado. Em outras palavras, nessa etapa seria verificado o cumprimento regular das obrigações fiscais pelo contribuinte.

${ }^{101}$ São exemplos de órgãos que podem ser consultados previamente à concessão do agrément (art. 344K, do anexo III do CGI): o Comitê de investimento de caráter econômico e social ("comité des investissements à caractère économique et social") e o Comitê interministerial de ajuda à localização de atividades ("comité interministériel des aides à la localisation des actvictés").
} 
(ou não) pelo Ministro da Economia, Finanças e Indústria ${ }^{102}$.

Durante o procedimento de concessão do agrément e mesmo após a decisão concessiva ou denegatória, deverão ser assegurados os direitos ao devido processo legal e ao contraditório ("direitos de defesa"). Assim, mesmo em caso de descumprimento dos compromissos assumidos pelo contribuinte beneficiário do agrément, este não poderá ser revogado sem que antes ele seja intimado a se manifestar e apresentar previamente suas observações. Da mesma forma, é garantida a assistência pelo representante de sua escolha. Estas são apenas algumas das garantias asseguradas durante o procedimento do agrément.

Uma das grandes vantagens do agrément fiscal é que esse instrumento permite que sejam favorecidas algumas atividades consideradas prioritárias pelo governo. Ele permite ainda que sejam levadas em consideração as particularidades das diversas situações e interesses em jogo, ao mesmo tempo em que se mantém o caráter geral das disposições legislativas em matéria fiscal. E, é em razão dessa mesma circunstância, que esse instrumento é também muito criticado: a outorga de um agrément fiscal poderia eventualmente beneficiar alguns em prejuízo de outros ${ }^{103}$.

A margem de liberdade da Administração tributária na concessão dos agréments varia conforme se trate de um agrément de pleno direito ou de um agrément discricionário: (a) nos agréments de pleno direito, a Administração somente poderá verificar se as condições trazidas pela legislação estão ou não presentes. Preenchidas tais condições, deverá outorgar o agrément solicitado, concedendo-lhe o regime tributário diferenciado. Trata-se, portanto, de competência vinculada da autoridade administrativa; (b) nos agréments discricionários, ao contrário, a Administração possui uma certa margem de liberdade de escolha. Ainda que preenchidas as condições estabelecidas na legislação, não estará ela obrigada a conceder o agrément.

A decisão de concessão ou denegação do agrément se dá por meio de uma decisão individual ("arrêté individuel"). Ela leva em consideração o texto legal que prevê tal

\footnotetext{
102 Atualmente, a competência para a outorga dos agréments fiscaux na França é da Divisão Geral de Finanças Públicas (DGFiP), por delegação do Ministro da Economia, Finanças e Indústria. Há uma possibilidade de delegação da decisão de concessão do agrément àqueles com nível de diretor departamental de impostos, com o objetivo de facilitar e acelerar a instrução e a concessão. Para Jean Lamarque, a recusa do Ministro em outorgar o agrément poderá ser objeto de um "recurso por excesso de poder", modalidade de impugnação judicial de decisões administrativas ilegais que se assemelha ao mandado de segurança em nosso sistema jurídico. Para uma análise detalhada dos pressupostos, autoridade competente para apreciar o recurso na hipótese de recusa de agrément, bem como os efeitos da decisão, conferir COLLET, Martin. Procédures fiscales: Contrôle, contentieux et recouvrement de l'impôt, Paris: PUF, 2007. p. 263-272.

${ }^{103}$ Conforme veremos, essa mesma crítica é efetuada em relação à transação em matéria tributária.
} 
modalidade de agrément, os termos do pedido formulado pelo requerente e os diferentes documentos por ele apresentados. Contém também as condições às quais a outorga do agrément está subordinada e, portanto, as obrigações do contribuinte titular do agrément. Estas condições podem decorrer dos compromissos inicialmente assumidos pela parte interessada, como também de iniciativa da própria Administração. Nesse último caso, tais condições deverão estar em consonância com o objetivo buscado pelo legislador quando da elaboração da norma que prevê o agrément.

Uma vez obtido o agrément, a parte interessada faz jus ao regime tributário acordado entre fisco e contribuinte ${ }^{104}$. No entanto, esse direito não é absoluto, possuindo prazo determinado e estando condicionado aos compromissos assumidos pela parte interessada quando de sua obtenção. Não havendo o cumprimento de tais compromissos até a data estipulada no agrément, a legislação francesa prevê uma espécie de exceção de inexecução do agrément, de sorte que o fisco não estaria obrigado a assegurar o regime derrogatório fixado no acordo ${ }^{105}$. Nessa hipótese, os particulares a quem as vantagens haviam sido concedidas são destituídos dos benefícios e/ou vantagens, sendo os impostos imediatamente exigíveis, acrescido dos juros de mora, salvo quando, eventualmente, entenda-se por bem limitar os efeitos de tal destituição ${ }^{106}$.

Vários foram os pedidos de agrément efetuados nos últimos anos na França. Para se ter uma idéia, somente no ano 2000, foram efetuados aproximadamente 1500 pedidos de agrément às autoridades francesas, dos quais mais de $50 \%$ foram concedidos ${ }^{107}$. Disso decorre que o número de pedidos de agrément, embora significativo, não parece inviabilizar as atividades da Administração fiscal.

${ }^{104}$ Conforme já analisado, para uma parcela da doutrina e da jurisprudência esse regime derrogatório concedido pela Administração fiscal ao contribuinte não seria "acordado", mas sim outorgado por meio de um ato unilateral, donde a inconsistência do termo "acordo" para qualificar tal instrumento jurídico.

${ }^{105}$ Nesse sentido o art. 1649, nonies A do Código Geral de Impostos (CGI) prevê que "quando os compromissos subscritos com o objetivo de obter um agrément administrativo não são executados ou quando as condições para a concessão deste não estiverem preenchidas, esta inexecução implica revogação do agrément concedido" (tradução livre).

${ }^{106}$ Vale ressaltar que o art. 1649 nonies A do CGI, com redação dada pela ordonnance de 7 de dezembro de 2005, constitui uma adaptação do antigo artigo 1756 do CGI. Os dois textos são bastante semelhantes, divergindo somente em relação a um único ponto: na redação anterior do art. 1756 constava que, uma vez revogado o agrément, os impostos que o contribuinte tivesse deixado de pagar tornavam-se imediatamente exigíveis, não obstante toda e qualquer disposição em contrário; na redação atual do art. 1649 nonies A não consta esse trecho. Com isso, admite-se que o contribuinte alegue a prescrição (quando já tiver havido o decurso do prazo prescricional), impedindo com isso a cobrança de uma parcela ou da totalidade dos tributos devidos nessa hipótese. (LAMARQUE, Jean; NÉGRIN, Olivier; AYRAULT, Ludovic. Manuel Droti fiscal général, Paris: Lexis Nexis, 2011, p. 452).

${ }^{107}$ Informação obtida do site da Administração francesa. Disponível em: <http://www.impots.gouv.fr>. Acesso em: 25 nov. 2012. 
Em conclusão, o agrément fiscal tem se mostrado um importante instrumento de incitação econômica. Sua utilização pelos particulares é resultado de um estímulo governamental para incentivar o contribuinte a exercer uma atividade priorizada pelo legislador, reforçando o cenário de maior colaboração entre fisco e contribuinte.

\subsubsection{Acordos em matéria de preços de transferência}

Um outro exemplo de instrumento de negociação entre contribuinte e Administração fiscal é o acordo prévio em matéria de preço de transferência, previsto nas legislações de alguns países.

Os acordos prévios em matéria de preços de transferência, mais conhecidos pela expressão inglesa advance pricing arrangements ou advance pricing agreements (APA) podem ser definidos como acordos celebrados entre o fisco e o contribuinte que fixam, previamente, um conjunto apropriado de critérios para a determinação do preço aplicável a operações com partes vinculadas. Esses critérios são os mais variados, podendo ser o método de cálculo mais adequado, elementos de comparabilidade e eventuais ajustes necessários. Em outras palavras, são acordos entre a Administração fiscal e o contribuinte onde são estabelecidas previamente as regras e critérios para determinar os preços a serem praticados, considerando, para tanto, o princípio de livre concorrência.

A negociação dos acordos prévios em matéria de preços de transferência pode envolver partes relacionadas e uma ou mais Administrações tributárias ${ }^{108}$. Disso resulta a classificação dos acordos, que podem ser de dois tipos: (a) acordos unilaterais: entre o contribuinte e a Administração fiscal do seu país; (b) acordos bilaterais ou multilaterais: onde, além do contribuinte e da Administração fiscal do seu país de origem, intervém também a Administração fiscal de um terceiro país (a Administração fiscal do país em que se localiza a parte relacionada).

É de se destacar que, muito embora a matéria afeta a um acordo unilateral ou bilateral seja eminentemente a mesma (o preço a ser praticado nas operações com parte vinculadas), os efeitos e vantagens de cada um desses tipos de acordo são distintos. $\mathrm{O}$ acordo unilateral tende a ser mais célere, já que envolve apenas o corpo de representantes de uma Administração físcal. Já o acordo bilateral é mais difícil de ser celebrado, na medida em que requer também a participação da Administração tributária do país onde se

108 OCDE. OECD Transfer Pricing Guidelines for Multinational Enterprises and Tax Administrations and Transfer Pricing Features of Selected Countries 2011. Netherlands: IBFD, 2010, p. 168. 
localiza a parte relacionada; mas, uma vez firmado, reduz consideravelmente a possibilidade de dupla tributação (ou dupla não tributação) e os riscos de questionamento quanto aos preços praticados.

De fato, na ausência de participação da Administração fiscal do outro país na definição do preço, dos critérios e dos métodos praticados, o contribuinte, mesmo tendo obtido um acordo prévio em matéria de preço de transferência com a sua Administração de origem, pode ser autuado na outra jurisdição quanto ao valor da operação, já que o físco do outro país não é obrigado a aceitar os termos do acordo firmado com terceiros ${ }^{109}$. Não é por outro motivo que a OCDE, na Transfer Pricing Guidelines for Multinational Entreprises and Tax Administrations, recomenda, sempre que possível, a utilização de acordos bilaterais, de forma a garantir maior segurança jurídica aos contribuintes ${ }^{110}$.

Em linhas gerais, e ressalvadas as especificidades da legislação de cada país, os acordos em matéria de preços de transferência se operacionalizam da seguinte forma: o contribuinte que pretender se assegurar de que os critérios e métodos de preços de transferência a serem praticados com uma parte relacionada atendem ao princípio da plena concorrência deverão, previamente ao início de suas operações, apresentar um requerimento à Administração fiscal ${ }^{111}$. Normalmente, o requerimento é acompanhado dos documentos fiscais, contábeis, comerciais e financeiros que dão suporte à operação (ou às operações) que o contribuinte submete à apreciação da Administração. A partir de então, começam as discussões entre contribuinte e fisco quanto aos critérios da operação e o preço que deverá ser considerado para fins de determinar o valor da operação entre as empresas vinculadas. Evidentemente, quando o acordo em questão é bilateral, as duas Administrações fiscais participarão do procedimento para a análise das operações. Após a

\footnotetext{
${ }^{109}$ Nesse sentido, a obra da OCDE destaca que "Unilateral APAs may present significant problems for tax administrations and taxpayers alike. From the point of view of other tax administrations, problems arise because they may disagree with the APA's conclusions. From the point of view of the associated enterprises involved, one problem is the possible effect on the behavior of the associated enterprises. Unlike bilateral or multilateral APAs, the use of unilateral APAs may not lead to an increased level of certainty for the taxpayer involved and a reduction in economic or juridical double taxation for the MNE group. If the taxpayer accepts an arrangement that over-allocates income to the country making the APA in order to avoid lengthy and expensive transfer pricing inquiries or excessive penalties, the administrative burden shifts from the country providing the APA to the other tax jurisdictions (...)". (OCDE. OECD Transfer Pricing Guidelines for Multinational Enterprises and Tax Administrations and Transfer Pricing Features of Selected Countries 2011. Netherlands: IBFD, 2010, p. 174).

${ }^{110}$ Ibid., p. 169.

${ }^{111}$ Nada impede que um acordo prévio em matéria de preços de transferência seja efetuado após o início das operações do contribuinte. Neste caso, porém, a Administração tributária estará vinculada aos seus termos tão somente em relação aos períodos futuros. Quer dizer, esses acordos, em princípio, não teriam efeitos retroativos.
} 
fase de discussões, quando a Administração fiscal concorda com os métodos e os critérios de preço de transferência que o contribuinte propõe praticar, ela informa tal decisão ao contribuinte, que deve, então, manifestar oficialmente sua aceitação aos termos do acordo.

A conclusão do acordo resulta em que a Administração não mais poderá efetuar ajustes nos preços praticados desde que o contribuinte respeite os termos do acordo. Entretanto, isso não significa dizer que o contribuinte terá direito adquirido por prazo indeterminado ao que foi estipulado no acordo prévio. Muito menos que ele está indefinidamente livre de qualquer fiscalização em relação aos preços praticados em suas operações intragrupo.

É que, normalmente, esse acordo poderá ser cancelado ou rescindido quando as operações do contribuinte forem alteradas significativamente ou quando circunstâncias econômicas fora de seu alcance afetarem a confiabilidade de sua metodologia ${ }^{112}$. Além disso, o fisco poderá, a qualquer momento, fiscalizar o contribuinte beneficiário do acordo, não em relação à metodologia aplicada, mas em relação à veracidade das informações inicialmente fornecidas e à continuidade fática destas, bem como em relação ao cumprimento das condições constantes do acordo.

Sobre a natureza jurídica de tais instrumentos, a doutrina não é uníssona. José Casalta Nabais destaca que esses acordos são exemplos típicos de contratos físcais, enquadrando-se na modalidade de contratos fiscais relativos à liquidação dos impostos ${ }^{113}$. Jean Lamarque não confronta essa opinião majoritária da doutrina, mas pondera que, no caso francês, a natureza contratual dos acordos em matéria de preço de transferência também é revestida de certas ambiguidades ${ }^{114}$. Independentemente da classificação adotada, é certa a compreensão de tais acordos como um instrumento de intensa participação do contribuinte na definição da matéria tributável.

Nesse sentido, e por serem mecanismos de negociação, os acordos em matéria de preços de transferência, de certa forma, assemelhar-se-iam ao ruling e mesmo ao instituto da consulta previsto no direito brasileiro. Essencialmente, esses mecanismos, mediante a participação do contribuinte, intentam conferir maior segurança jurídica, aclarando previamente as consequências jurídicas de suas operações. Todavia, há diferenças entre os dois institutos: o acordo em matéria de preços de transferência é, via de regra, muito mais

\footnotetext{
112 CASTAGNÈDE, Bernard. Précis de fiscalité internationale. Paris: PUF, 2010, p. 124.

${ }^{113}$ NABAIS, José Casalta. Direito Fiscal. Coimbra: Almedina, 2010, p. 201.

${ }^{114}$ LAMARQUE, Jean et al. Manuel Droit fiscal général. Paris: Lexis Nexis, 2011, p. 444.
} 
complexo que a consulta e o ruling, já que analisa diversos elementos econômicos e muitos elementos de comparação; o acordo prévio em matéria de preços de transferência trata, sobretudo, de matéria fática, enquanto a consulta analisa questões de natureza jurídica, baseadas em fatos trazidos pelo contribuinte; os fatos analisados numa consulta não podem ser questionados pela autoridade fiscal, que somente analisará as consequências tributárias deles decorrentes, enquanto que nos acordos prévios de preço de transferência os fatos também poderão ser questionados pelo fisco; e, finalmente, o acordo prévio envolve a análise de uma série de operações praticadas pelo contribuinte, enquanto a consulta normalmente se refere a uma operação específica ${ }^{115}$.

Importa destacar que além do objetivo primordial dos acordos prévios em matéria de preços de transferência de dar previsibilidade ao tratamento tributário a ser conferido pela Administração fiscal às operações efetuadas pelos contribuintes, garantindo com isso uma maior segurança jurídica, outros objetivos igualmente importantes no contexto atual são também atingidos com essa espécie de acordo. De um lado, os acordos prévios permitem que a Administração tributária e o contribuinte desenvolvam uma relação de colaboração mútua, na medida em que há uma certa abertura das informações do contribuinte perante o fisco e que várias questões tributárias de alta complexidade são discutidas em conjunto. De outro lado, a apresentação voluntária de diversas informações pelo contribuinte evita fiscalizações futuras, além de reduzir a litigiosidade tanto na esfera administrativa quanto judicial e, com isso, o alto custo a ela relacionado ${ }^{116}$.

\subsection{Perspectivas para a resolução de conflitos tributários: a transação}

Conforme visto nos itens precedentes, o Direito Tributário contemporâneo sofreu inúmeras transformações nos últimos anos. Essas mudanças podem ser observadas na busca por uma maior legitimidade social do tributo, uma maior eficiência das autoridades tributárias e no estreitamento das relações entre físco e contribuinte. Resultam de uma mudança completa de paradigmas: de uma relação de confronto para uma relação de colaboração. Nesse contexto, a idéia do contratualismo em matéria tributária entre fisco e contribuinte, que até recentemente era inconcebível, por força dos princípios da legalidade e da igualdade tributária, hoje deixa de apresentar esse aspecto obtuso.

\footnotetext{
115 OCDE. OECD Transfer Pricing Guidelines for Multinational Enterprises and Tax Administrations and Transfer Pricing Features of Selected Countries 2011. Netherlands: IBFD, 2010, p. 170.

${ }^{116}$ Ibid., p. 173-174.
} 
De fato, as operações efetuadas pelos contribuintes são cada vez mais complexas, gerando dúvidas quanto à incidência ou não do tributo, bem como sua respectiva quantificação. Some-se a isso o fato de que a discordância do contribuinte em relação ao tributo que lhe é exigido certamente dará ensejo a um procedimento litigioso caro, não somente para o contribuinte, como também para o Estado. Assim, nada mais lógico do que permitir que a Administração utilize mecanismos de negociação tributária como forma de melhor gerir os seus recursos, sempre na busca de uma maior eficiência.

É justamente nesse contexto de modernização do Direito Tributário que se insere a transação em matéria tributária.

\subsubsection{A transação como método de solução de conflitos no cenário internacional}

A transação em matéria tributária consiste em uma mecanismo alternativo de composição de conflitos que vem ganhando força em vários países do mundo. $\mathrm{Na}$ transação, as próprias partes envolvidas na controvérsia fazem concessões, abrindo mão de suas posições iniciais, para chegar a um consenso ${ }^{117}$. Trata-se de instrumento cujo objetivo é colocar fim a eventuais discussões entre fisco e contribuinte, assegurando maior celeridade à resolução de conflitos. Embora este instituto necessite de mais estudos, sua adoção parece se coadunar com o atual estágio do Direito Tributário, encontrando respaldo já na legislação de diversos países pelo mundo afora ${ }^{118}$.

O estudo do instituto da transação tributária no direito estrangeiro é bastante relevante. É que, em um mundo globalizado, não é mais possível falar em sistemas jurídicos hermeticamente isolados uns dos outros. Os problemas tributários enfrentados pelos diversos países assemelham-se. O mesmo ocorre em relação ao volume de demandas administrativas e judiciais. A sobrecarga do Judiciário, assim como a lentidão dos processos que nele tramitam, não é uma peculiaridade exclusiva do nosso sistema. Outros países enfrentam os mesmos problemas e adotaram a transação como solução.

A forma como a transação em matéria tributária se apresenta em outros países não será analisada neste trabalho com o intuito de copiá-la ipsis litteris. A transposição de normas estrangeiras à realidade brasileira, sem contudo entender o contexto em que foram

\footnotetext{
${ }^{117}$ SCHOUERI, Luís Eduardo. Direito Tributário. São Paulo: Saraiva, 2013, p. 624.

${ }^{118}$ Uma análise detalhada do instituto da transação em matéria tributária no direito brasileiro será feita no Capítulo III deste trabalho.
} 
editadas, poderá acarretar consequências desastrosas ${ }^{119}$. Em realidade, o que se pretende é analisar o funcionamento e a eficácia desse instituto em outros sistemas jurídicos, para verificar se seria possível sua adoção e implementação no Brasil. Nesse sentido, não se propõe a importação pura e simples do instituto da transação tributária, na forma em que se encontra na legislação estrangeira, mas sim a compreensão das particularidades e do contexto em que esse instituto se desenvolveu em outros países, de forma a que se possa, compreendendo seus pontos fortes e fracos, eventualmente, adotá-lo no nosso país.

Por essas razões é que se contextualiza a discussão sobre a transação em matéria tributária a partir da experiência de alguns países, notadamente, a França, a Itália e os Estados Unidos. A escolha dos três países examinados, em detrimento de outros, foi motivada pela maior familiaridade com os sistemas jurídicos em questão. De toda forma, cumpre destacar que, embora a análise tenha recaído sobre esses três países, outros ordenamentos jurídicos também dispõem de institutos que se assemelham à transação tributária, como é o caso da Espanha e do México ${ }^{120}$.

\subsubsection{A transação tributária no Direito francês}

A França utiliza a transação em matéria fiscal como forma de colocar fim à um litígio fiscal há algum tempo. Emprestado originalmente do Direito Civil (art. 2044 e ss. do Código Civil francês) ${ }^{121}$, a transação tributária entre fisco e contribuintes estava prevista já em uma ordonnance de $1822^{122}$. No entanto, esse instituto sempre foi utilizado de forma bastante restrita. Essa restrição se baseava sobretudo na submissão da Administração aos princípios da legalidade e igualdade, segundo os quais a Administração deveria se pautar pelo conjunto de regras de direito, o que não lhe

\footnotetext{
${ }^{119}$ Na mesma linha, sobre a transposição do sistema norte-americano à França, é o entendimento de Alexis de Tocqueville: "Ne tournons pas nos regards vers l'Amérique pour copier servilement les institutions qu'elle s'est donné, mais pour mieux comprendre celles qui nous conviennent, moins pour y puiser des exemples que des enseignements, pour lui emprunter les principes plutôt que les détails de ses lois." TOCQUEVILLE, Alexis de. De la démocratie en Amérique apud BERTRAND, Henriette. Le contrôle fiscal aux États-Unis. Tese (Doutorado em Direito) Universidade de Paris I Panthéon-Sorbonne, 2004, p. 7.

${ }^{120}$ DACOMO, Natalia de Nardi. Direito Tributário participativo: transação e arbitragem administrativas da obrigação tributária. Tese (Doutorado em Direito), Faculdade de Direito da Pontifícia Universidade Católica de São Paulo, 2008, p. 179 et seq; JUNQUEIRA, Helena Marques Junqueira. Transação Tributária. Tese (Doutorado), Faculdade de Direito da Pontifícia Universidade Católica de São Paulo, 2009, p. 154 et seq; GODOY, Arnaldo Sampaio de Moraes. Transação Tributária: introdução à justiça fiscal consensual. Belo Horizonte: Fórum, 2010, p. 77 et seq.

${ }^{121}$ De acordo com o artigo 2044 do Código Civil francês: "La transaction est un contrat par lequel les parties terminent une contestation née ou préviennent une contestation à naître."

${ }^{122}$ COLLET, Martin. Droit fiscal. Paris: Themis Droit PUF, 2007, p. 195.
} 
permitiria margens a concessões em face de contribuintes específicos ${ }^{123}$.

Prevista inicialmente em relação a apenas alguns tributos, posteriormente a transação fiscal foi ampliada aos demais tributos ${ }^{124}$. Atualmente, ela está regulamentada no art. L 247 e seguintes do Código de Procedimentos Fiscais (Livre de Procédures Fiscales ou $L P F)$. O legislador francês inseriu a transação como um instrumento de "juridiction gracieuse" ${ }^{225}$, previsto no Capítulo III (les remises et transactions à titre gracieux), no Título II, reservado ao contencioso administrativo de imposição (contentieux de l'impôt) que se difere do contencioso de cobrança (contentieux $d u$ recouvrement). Tratou-se da transação tributária juntamente com as hipóteses de remises gracieuses $^{126}$.

De acordo com a legislação francesa, a autoridade fiscal poderá, a requerimento do contribuinte, conceder uma redução das penalidades administrativas relacionadas aos tributos e obrigações acessórias devidas ${ }^{127}$. No entanto, depois de 2004, passou-se a admitir a transação não somente em relação às penalidades administrativas, mas também em relação aos juros moratórios ${ }^{128}$. Em qualquer caso, porém, a Administração físcal francesa não poderá transacionar em relação ao tributo propriamente dito, mas tão somente em relação aos seus acessórios ${ }^{129}$.

Além da limitação material (penalidades e juros), existe também uma limitação temporal. De acordo com a legislação, não poderá haver transação a partir do momento

\footnotetext{
${ }^{123}$ A esse respeito, o Conselho de Estado, ao julgar uma questão relacionada à transação, entendeu que a transação poderia acarretar a concessão de liberalidades pela Administração o que iria de encontro às regras orçamentárias (CE, 17 mars 1893, Campagnie du Nord de l'Est et al., Rec. p. 245).

${ }^{124}$ Inicialmente, a transação em matéria tributária se aplicava tão somente ao impostos sobre o faturamento (taxes sur le chiffre d'affaires) e às contribuições indiretas (contributions indirectes). (GROSCLAUDE, Jacques; MARCHESSOU, Philippe. Procédures Fiscales. Paris: Dalloz, 2012, p. 273 et seq).

${ }^{125}$ No Direito francês, a distinção entre o caráter gracioso ou contencioso de um requerimento depende sobretudo da fundamentação apresentada pelo contribuinte: (a) uma reclamação formulada com base em argumentos jurídicos constitui um requerimento de jurisdição contenciosa; (b) um pedido formulado pelo contribuinte de redução de penalidades e juros, sem qualquer questionamento fundado em argumentos jurídicos, constitui um requerimento de jurisdição graciosa.

${ }^{126}$ As remises gracieuses são uma espécie de perdão de dívida concedido pela Administração fiscal sob requerimento das partes nas hipóteses de impossibilidade de pagamento devido a dificuldades financeiras do contribuinte (art. 247, $1^{\circ}$ do $L P F$ ).

${ }^{127}$ De acordo com o art. 247 do LPF: "L'administration peut accorder sur la demande du contribuable: [...], $3^{\circ}$ Par voie de transaction, une atténuation d'amendes fiscales ou de majorants d'impôts lorsque ces pénalités et, le cas échéant, les impositions auxquelles elles s'ajoutent ne sont pas définitives."

${ }^{128}$ A partir da Lei $\mathrm{n}^{\circ}$ 2003-1311 de 30 de dezembro de 2003, art. 35: "les dispositions des $2^{\circ}$ et $3^{\circ}$ sont le cas échéant applicables s'agissant des sommes dues au titre de l'intérêt de retard visé à l'article 1727 du code général des impôts".

${ }^{129}$ LAMARQUE, Jean; NÉGRIN, Olivier; AYRAULT, Ludovic. Droit Fiscal Général. Paris: LexisNexis, 2011, p. 439. Segundo o autor, trata-se de uma interpretação a contrario do dispositivo legal. Nesse mesmo sentido, pode ser observada manifestação da Administração fiscal francesa (Doc. adm. DGI, 13 S-2, nº4).
} 
em que a tributo sobre o qual incide as penalidades e os juros se tornar definitivo. Em outras palavras, a transação somente poderá ocorrer durante o denominado contentieux de l'impôt ou contentieux de l'assiette, onde Administração e contribuinte discutem a legalidade da imposição e dos valores lançados pelo fisco. Martin Collet ressalta que, após a conclusão do contentieux de l'assiette, não existe mais interesse da Administração em transacionar ${ }^{130}$. Terminada essa fase, a transação não pode mais se realizar ${ }^{131}$.

Dada a noção contratual do instituto, a transação em matéria fiscal, prevista pela legislação francesa, baseia-se na idéia de concessões recíprocas das partes envolvidas. De um lado, a Administração fiscal concede ao contribuinte uma redução das penalidades e dos juros moratórios incidentes sobre o tributo em discussão, renunciando a levar a questão perante os tribunais (especialmente em matéria penal). De outro, o contribuinte beneficiário da transação se compromete a pagar ao fisco o tributo devido e os valores acordados em relação às penalidades administrativas e juros moratórios, renunciando igualmente a todo tipo de procedimento judicial presente e futuro não somente em relação aos acessórios como também ao valor do tributo devido a título de principal ${ }^{132}$.

No entanto, para que a transação acarrete esses efeitos, são necessárias duas condições: (a) que a autoridade fiscal competente aprove o acordo celebrado com o contribuinte $^{133}$; e (b) que as partes cumpram com as suas respectivas obrigações constantes do instrumento transacional. Somente a partir desse momento é que a transação pode ser considerada definitivamente concluída e, por conseguinte, as partes não poderão mais levar ou retomar a discussão perante as autoridades administrativas e judiciais ${ }^{134}$. Após a conclusão da transação, eventuais questionamentos por quaisquer das partes, seja em relação ao tributo ou seus acessórios, não serão sequer conhecidos ${ }^{135}$.

\footnotetext{
${ }^{130}$ COLLET, Martin. Droit Fiscal. Paris: Thémis Droit PUF, 2007, p. 196.

${ }^{131}$ Nessa hipótese, no entanto, a Administração, a requerimento do contribuinte, poderá conceder uma redução unilateral das penalidades administrativas e juros moratórios, bem como dos tributos propriamente ditos, nas situações previstas de remise gracieuse (art. L 247, $1^{\circ}$ e 2 do LPF).

${ }^{132}$ LAMARQUE, Jean; NÉGRIN, Olivier; AYRAULT, Ludovic. Droit Fiscal Général. Paris: LexisNexis, 2011, p. 440.

${ }^{133}$ De acordo com o Conselho de Estado francês, uma proposta de transação feita pelo fiscal e aceita pelo contribuinte, mas não aprovada pelo superior hierárquico competente, em conformidade com as disposições regulamentares sobre a matéria, não possui o condão de impedir que a Administração fiscal notifique o interessado do lançamento efetuado, desde que evidentemente dentro do prazo de prescrição (CE 11 juil. 1973, req. ${ }^{\circ}$ 81913: Dr. Fisc. 1974, comm. 1084, concl. Delmas-Marsalet).

${ }^{134} \mathrm{O}$ art. L 251 do LPF francês dispõe que: "Lorsqu'une transaction est devenue définitive après accomplissement des obligations qu'elle prévoit et approbation de l'autorité compétente, aucune procédure contentieuse ne peut plus être engagée ou reprise pour remettre en cause les pénalités qui ont fait l'objet de la transaction ou les droits eux-mêmes".

${ }^{135}$ Nesse sentido, convém notar que: "La conclusion en cours d'instance d'une transaction doit conduire le
} 
Com efeito, tanto na hipótese da Administração fiscal ter se equivocado em relação ao valor de sua proposta de transação, quanto na hipótese do contribuinte ter cometido um erro em relação aos tributos sobre os quais incidiriam as penalidades e juros objeto da transação, ambos não poderão contestar o acordo celebrado. Desta forma, se por um lado a Administração não pode cobrar do contribuinte a totalidade ou uma parcela da penalidade e dos juros que renunciou quando da celebração da transação, por outro o contribuinte não poderá requerer a restituição dos valores eventualmente pagos a maior ou pagos em razão de um tributo ilegalmente instituído ${ }^{136}$.

No que tange ao atual procedimento de transação em matéria tributária no Direito francês, importa ressaltar que a transação inicia-se com um requerimento da parte do contribuinte endereçado à autoridade fiscal competente. A partir de então, uma proposta de transação será apresentada ao contribuinte. Essa proposta conterá o valor do imposto devido, bem como do remanescente de penalidades e juros de mora deixados a cargo do contribuinte. A autoridade competente para decidir acerca da transação varia conforme o valor envolvido: se o valor for inferior a $€ 150.000$, será de competência do diretor de serviços fiscais; se o valor for superior, será de competência do respectivo Ministro, após a oitiva de um comitê $\hat{~}^{137}$.

Por fim, importa ressaltar que, apesar de a transação ser um instrumento de há muito consolidado no Direito francês, sua utilização, tanto pela Administração quanto pelos contribuintes, é bastante restrita. Sobre o assunto, Martin Collet ressalta que, mesmo que a Administração fiscal incite seus agentes a utilizar esse instrumento para encerrar amigavelmente os litígios com os contribuintes, na prática, a transação tributária é pouco utilizada $^{138}$. Um dos argumentos levantados por Helena Marques Junqueira para o número reduzido de transações fiscais na França é a complexidade do instituto que seria utilizado

juge fiscal à prononcer un non-lieu à statuer à l'égard des impositions en litige. Il en va de même devant le juge répressif où l'intervention d'une transaction en cours d'instance interdit toute condamnation du contribuable poursuivi pour fraude fiscale". (LAMARQUE, Jean; NÉGRIN, Olivier; AYRAULT, Ludovic. Droit Fiscal Général. Paris: LexisNexis, 2011, p. 440).

${ }^{136}$ LAMARQUE, Jean; NÉGRIN, Olivier; AYRAULT, Ludovic. op. cit., p. 441.

${ }^{137}$ De acordo com o artigo R 247-4 do LPF: "Sauf en matière de contributions indirectes, la décision sur les demandes des contribuables tendant à obtenir une modération, remise ou transaction appartient: a) au directeur chargé d'une direction des services fiscaux ou au directeur chargé d'un service à compétence nationale ou d'une direction spécialisée pour les affaires relatives à des impositions établies à l'initiative des agents placés sous son autorité, lorsque les sommes faisant l'objet de la demande n'excèdent pas 150.000€ par cote, exercice ou affaire, selon la nature des impôts; b) au ministre chargé du budget, après avis du comité du contentieux fiscal, douanier et des changes, dans les autres cas".

${ }^{138}$ COLLET, Martin. Droit Fiscal. Paris: Thémis Droit PUF, 2007, p. 196. 
tão somente por grandes empresas acompanhadas por advogados especializados ${ }^{139}$.

\subsubsection{A transação tributária no Direito italiano}

Assim como ocorre em outros países, a Itália admite há muito tempo institutos que se assemelham à transação tributária. $\mathrm{O}$ objetivo desses instrumentos é a extinção dos conflitos tributários por meio de um acordo celebrado entre fisco e contribuintes. Além da redução significativa da litigiosidade, garante-se segurança ao contribuinte, ao mesmo tempo em permite a célere obtenção de recursos pelo Estado ${ }^{140}$.

Como destaca Carlos Yuri Araújo Morais, a Itália possui grande experiência na solução alternativa de conflitos em matéria tributária. No passado, havia previsão de um instituto denominado concordato $^{141}$. Tal instrumento permitia que fisco e contribuinte celebrassem um acordo durante o procedimento de lançamento fiscal, que tinha o condão de determinar o valor tido como incontroverso.

Esse acordo, no entanto, não possuía caráter definitivo. É que, as comissões tributárias de primeira instância poderiam eventualmente revogá-lo, aumentando a base de cálculo do imposto devido. Por essa razão, José Casalta Nabais ressalta que, nessa época, a natureza jurídica do concordato tributario era bastante controvertida, prevalecendo o entendimento segundo o qual esse instituto não possuía natureza contratual, mas sim de um ato administrativo unilateral carecido de colaboração ${ }^{142}$.

139 JUNQUEIRA, Helena Marques Junqueira. Transação Tributária. Tese (Doutorado), Faculdade de Direito da Pontifícia Universidade Católica de São Paulo, 2009, p. 156.

140 BUSA, Vincenzo. Gli instituti deflativi del contenzioso nell'esperienza italiana: a experiência italiana sobre transação e conciliação em matéria tributária e demais modalidades alternativas de solução de controvérsias fiscais. In: TÔRRES, Heleno Taveira (Coord.). Direito Tributário Internacional Aplicado Volume V, São Paulo: Quartier Latin, 2008, p. 529.

${ }^{141}$ MORAIS, Carlos Yuri Araújo Morais. Transação e Arbitragem em Matéria Tributária: a experiência estrangeira e sua aplicabilidade no direito brasileiro. In: SARAIVA FILHO, Oswaldo Othon de Pontes; GUIMARÃES, Vasco Branco (Orgs.). Transação e Arbitragem no Âmbito Tributário. Belo Horizonte: Fórum, 2008, p. 493-495. Segundo o autor, o concordato instituído em 1907 previa a possibilidade de um acordo entre Administração tributária e contribuinte para determinar o rendimento imponível para fins de imposto di richezza mobile.

${ }^{142}$ José Casalta Nabais destaca, todavia, que, quando das seguidas reformas ocorridas na legislação italiana ganhou força na doutrina a tese da natureza contratual do instituto. É que, a partir de 1956, com a denominada reforma Tremelloni, as comissões tributárias passaram a somente poder modificar ou integrar os lançamentos quando diante de novos elementos de fato, podendo ser considerada como uma hipótese de rescisão contratual. (NABAIS, José Casalta. Contratos Fiscais: reflexões acerca da sua admissibilidade. Coimbra: Coimbra, 1994, p. 101 et seq). Sobre a natureza jurídica do concordato tributario, conferir também o pensamento de Natália de Nardi Dacomo. A autora destaca que havia controvérsia na doutrina a esse respeito: uma parte considerava que o instituto tinha natureza contratual; outra, que se tratava de um ato unilateral, embora dependesse de adesão do contribuinte; uma terceira, que reconhecia a natureza consensual do acordo, tivesse ele natureza contratual ou não. (DACOMO, Natalia de Nardi. Direito Tributário participativo: transação e arbitragem administrativas da obrigação tributária. Tese (Doutorado 
Atualmente, um instituto semelhante à transação em matéria tributária é previsto no Direito italiano no Decreto Legislativo $\mathrm{n}^{\mathrm{o}}$ 218, de 19 de junho de 1997, que regulamentou a Lei ${ }^{\circ} 662$, de 23 de dezembro de 1996, sob o nome de accertamento con adesione. Esse instituto permite a participação do contribuinte no procedimento de lançamento tributário (também denominado em italiano de “accertamento”).

Trata-se de um acordo que ocorre durante a fase administrativa do procedimento de lançamento ${ }^{143}$. Assim é que, efetuada a proposta de lançamento pelo fisco, o contribuinte poderá impugná-lo, questionando seu fundamento e apresentando as provas a seu favor ${ }^{144}$. Uma vez efetuado o lançamento, contendo o valor a ser cobrado, as partes (fisco e contribuinte) poderão celebrar um acordo em que se defina o valor devido, hipótese em que o contribuinte adere ao lançamento.

O accertamento con adesione é bastante amplo. Não está adstrito a requisitos, nem a modalidades específicas de lançamento. Ademais, pode ele abranger diversas espécies de tributos, bem como vários períodos de apuração ${ }^{145}$. A iniciativa para sua celebração pode ser do contribuinte ou do fisco. Em regra, seu procedimento é composto de quatro fases: (a) a iniciativa do físco ou do contribuinte; (b) o contraditório; (c) a formação da proposta de adesão; e (d) o perfazimento do ato de adesão pelo contribuinte ${ }^{146}$.

Uma das principais consequências desse instituto consiste em que ele vincula as partes, que não mais poderão questioná-lo: o contribuinte não poderá impugnar o lançamento cujos termos aderiu, do mesmo modo que não será permitido ao físco integrar ou modificar o lançamento, salvo quando o acordo celebrado contiver alguma espécie de vício de consentimento ou em algumas circunstâncias específicas ${ }^{147}$.

em Direito), Faculdade de Direito da Pontifícia Universidade Católica de São Paulo, 2008, p. 170-171).

143 BUSA, Vincenzo. Gli instituti deflativi del contenzioso nell'esperienza italiana: a experiência italiana sobre transação e conciliação em matéria tributária e demais modalidades alternativas de solução de controvérsias fiscais: In: TÔRRES, Heleno Taveira (Coord.). Direito Tributário Internacional Aplicado Volume V, São Paulo: Quartier Latin, 2008, p. 529.

144 JUNQUEIRA, Helena Marques. Transação Tributária. Tese (Doutorado em Direito), Faculdade de Direito da Pontifícia Universidade Católica de São Paulo, 2009, p. 156.

${ }^{145}$ MORAIS, Carlos Yuri Araújo Morais. Transação e Arbitragem em Matéria Tributária: a experiência estrangeira e sua aplicabilidade no direito brasileiro. In: SARAIVA FILHO, Oswaldo Othon de Pontes; GUIMARÃES, Vasco Branco (Orgs.). Transação e Arbitragem no Âmbito Tributário. Belo Horizonte: Fórum, 2008, p. 494.

146 INFANTE, Gianni. L'accertamento con adesione. Tese de Láurea (Láurea em Administração, Finanças e Gestão), Faculdade de Economia da Universidade Ca'Foscari de Veneza, 2009/2010, p. 47.

${ }^{147}$ Nesse sentido, Vicenzo Busa destaca ser possível a integração e revisão do lançamento na hipótese em que sobrevier conhecimento pelo fisco de elemento novo que possa dar ensejo a um rendimento não declarado superior a $50 \%$ daquele definido no lançamento por adesão; isso desde que o valor remanscente não seja inferior a 25.000€. (BUSA, Vincenzo. op. cit., p. 533). 
Outro instrumento previsto no Direito italiano que se assemelha à transação em matéria tributáira é a conciliazione giudiziale. Diferentemente do accertamento con adesione, que ocorre durante a fase administrativa, a conciliazione giudiziale, prevista no Decreto-lei $\mathrm{n}^{\mathrm{o}}$ 564, de 30 de setembro de 1994, convertido na Lei ${ }^{\circ}$ 656, de 30 de novembro de 1994, como seu nome indica, ocorre na fase judicial.

Esse instrumento permite uma nova oportunidade para que fisco e contribuinte cheguem a um acordo em relação ao valor do tributo devido, pondo fim à controvérsia existente entre ambos. Trata-se de mais um incentivo para reduzir a litigiosidade, bem como para diminuir o tempo de tramitação do processo judicial e dos custos a ele inerentes. Ademais, justifica-se pelo risco de derrota na ação judicial, admitindo-se sua utilização até que uma decisão em primeira instância seja proferida ${ }^{148}$.

Conforme destaca Natália De Nardi Dacomo, a doutrina italiana distingue duas modalidades de conciliazione giudiziale ${ }^{149}$ : (a) o acordo preventivo; e (b) o acordo perante o juízo. No primeiro, fisco e contribuinte chegam a um acordo prévio subscrito por ambos e este acordo é apresentado em juízo para homologação. No segundo, um acordo é obtido em juízo, durante a audiência, sendo formalizado por um documento denominado "ato de conciliação", que servirá de título executivo para a cobrança dos valores.

Não importa em qual das modalidades acima, a conciliazione giudiziale é um acordo celebrado entre físco e contribuinte ${ }^{150}$. Estes é que definirão o seu conteúdo. $\mathrm{O}$ juízo não interfere nos seus termos e condições. Ao juiz compete apenas verificar os pressupostos e condições de admissibilidade do acordo celebrado e homologá-lo ${ }^{151}$. Uma vez homologada a conciliazione giudiziale, o processo será extinto.

Vale notar que a legislação italiana previa também o instituto da transazione fiscale de forma genérica. Este instituto era aplicável ao crédito tributário líquido e exigível, sobretudo quando houvesse risco de não recuperação do crédito pelo fisco. Baseava-se no princípio da eficiência. Entretanto, na prática, teve aplicação bastante

\footnotetext{
148 MICHELIN, Dolizete Fátima. O anteprojeto da Lei Geral de Transação em Matéria Tributária e os princípios constitucionais da legalidade, isonomia e moralidade administrativa. In: SARAIVA FILHO, Oswaldo Othon de Pontes; GUIMARÃES, Vasco Branco (Orgs.). Transação e Arbitragem no Âmbito Tributário. Belo Horizonte: Fórum, 2008, p. 343.

149 DACOMO, Natalia de Nardi. Direito Tributário participativo: transação e arbitragem administrativas da obrigação tributária. Tese (Doutorado em Direito), Faculdade de Direito da Pontifícia Universidade Católica de São Paulo, 2008, p. 176.

${ }^{150}$ Ibid., p. 175-176.

151 JUNQUEIRA, Helena Marques. Transação Tributária. Tese (Doutorado em Direito), Faculdade de Direito da Pontifícia Universidade Católica de São Paulo, 2009, p. 156.
} 
reduzida, em especial, em razão da controvérsia envolvendo a indisponibilidade do crédito tributário e a dificuldade de se avaliar a possibilidade de recuperação do crédito. Atualmente a aplicação desse instituto é restrita aos procedimentos falimentares ${ }^{152}$.

Por fim, recentemente, em 2012, a legislação italiana criou mais um instrumento de solução alternativa de controvérsias em matéria tributária, com o objetivo de reduzir o tempo, o custo e a incerteza de um processo judicial. Trata-se da denominada “mediazione tributaria”, criada pelo Decreto-lei n 98, de 06 de julho de 2011, e em vigor a partir de abril de 2012. Esse instituto, que não tem características de transação propriamente dita, configura-se como uma condição de admissibilidade para a interposição de recurso administrativo. Apesar das críticas da doutrina em relação à mediazione tributaria, uma das justificativas para tal iniciativa é justamente a tentativa de se melhorar ainda mais as relações entre fisco e contribuinte ${ }^{153}$.

\subsubsection{A transação tributária no Direito norte-americano}

A exemplo da França e demais países, os Estados Unidos da América (EUA) também utilizam instrumentos semelhantes à transação como mecanismo de solução de controvérsias em matéria tributária.

A evolução da transação em matéria tributária nos EUA está intrinsecamente relacionada a uma série de reformas institucionais sofridas pela Administração tributária norte-americana ao longo dos anos. Isso porque, de acordo com Henriette Bertrand, a prática daquele país é de valer-se menos dos meios coercitivos de cobrança do crédito tributário e mais de procedimentos informais de negociação entre fisco e contribuinte, de sorte a melhorar as relações fisco-contribuinte ${ }^{154}$.

A utilização de acordo como meio alternativo de solução de controvérsias decorre

\footnotetext{
152 BUSA, Vincenzo. Gli instituti deflativi del contenzioso nell'esperienza italiana: a experiência italiana sobre transação e conciliação em matéria tributária e demais modalidades alternativas de solução de controvérsias fiscais. In: TÔRRES, Heleno Taveira (Coord.). Direito Tributário Internacional Aplicado Volume V, São Paulo: Quartier Latin, 2008, p. 538.

153 Algumas das críticas ao instituto da mediazione tributaria consistem principalmente no fato que teria sido criado por Decreto-lei e que o mediador seria um outro órgão da Administração Pública, colocando em jogo sua imparcialidade. Cf. PRESS: Professione Economica e Sistema Sociale $\mathrm{n}^{\circ} 43$, aprile 2012. Seção People. Disponível em: <http://www.commercialisti.it/MediaContentResource.ashx?/PortalResources /Press/5a55d604-9e1c-46ea-a6 bf-0c1a0b16da4b/2012\%20APRILE.pdf $>$. Acesso em: 10 mar. 2013.

${ }^{154}$ Além disso, segundo Henriette Bertrand, mesmo as alterações sofridas na estrutura organizacional do fisco norte-americano (Internal Revenue Service), para substituir o critério geográfico de repartição de sua estrutura pelo critério de especialidade conforme à atividade econômica exercida pelo contribuinte, tiveram também por objetivo facilitar as relações fisco-contribuintes. (BERTRAND, Henriette. Le controle fiscal aux États-Unis. Tese (Doutorado em Direito) da Universidade de Paris I Panthéon-Sorbonne, 2004, p. 11).
} 
da própria cultura norte-americana. Esses mecanismos alternativos para a resolução de controvérsias são utilizadas não somente no Direito Tributário como também nos demais ramos do direito, notadamente, no Direito Processual Civil e no Direito Penal ${ }^{155}$. O acesso a esses mecanismos se dá de forma simples e desburocratizada. O fisco disponibiliza diversos formulários aos contribuintes, cada qual com consequências próprias ${ }^{156}$.

A doutrina destaca a existência de duas modalidades principais de acordos em matéria tributária que podem ser celebrados entre fisco e contribuinte e que encontram respaldo no ordenamento jurídico norte-americano. São elas: (a) os closing agreements (acordos terminativos); e (b) os offers in compromise (ofertas de compromisso). Ambas modalidades encontram-se previstas no capítulo 74 do Internal Revenue Code (IRC) $)^{157}$.

Os closing agreements, previstos no $\S 7121$ do $I R C$, são acordos extrajudiciais celebrados entre o físco e os contribuintes. Esta modalidade de acordo põe fim à controvérsia existente antes mesmo dessa ser levada aos tribunais. Uma vez celebrado o acordo, este encerra, de forma final e definitiva, as controvérsias existentes entre as partes. Seu conteúdo poderá abranger qualquer tributo e qualquer período impositivo ${ }^{158}$.

Conforme se depreende da redação do dispositivo, a competência para celebração dos closings agreements é do Secretário do Tesouro. Esta competência, entretanto, foi delegada ao Comissário do IRS, que, por sua vez, delegou-a às repartições locais. Na prática, compete aos agentes da repartição fiscal a que o contribuinte esteja vinculado

\footnotetext{
${ }^{155}$ Arnaldo Sampaio Godoy explica que: “A maior parcela das discussões que envolvem contribuintes e autoridades fiscais norte-americanas resolve-se por algum tipo de transação. Há comprometimento do Estado com políticas que conduzam a alguma forma de acordo. É da cultura normativa norte-americana a alternativa da transação, circunstância historicamente plasmada no processo civil e no processo penal, como nos dá conta a figura do plea bargaining”. (GODOY, Arnaldo Sampaio de Moraes. Transação e Arbitragem no Direito Norte-Americano. In: SARAIVA FILHO, Oswaldo Othon de Pontes; GUIMARÃES, Vasco Branco (Orgs.). Transação e Arbitragem no Âmbito Tributário. Belo Horizonte: Fórum, 2008, p. 425).

${ }^{156}$ WATSON, Camilla E. Tax Procedure and Tax Fraud in a nutshell. [S.L.]: Thompson, 2006 p. 108-109 e 195-196. De acordo com a professora da Universidade da Georgia, dependendo do formulário escolhido pelo contribuinte, ser-lhe-á ou não possível rediscutir a matéria objeto do acordo em juízo. Segundo a autora, seriam vários os formulários, destacando-se: o formulário 870 (consent to assessment); o formulário $870 \mathrm{AD}$ (agreement to assessment); e o formulário 866 e 906 (closing agreements). Além disso, haveria também o formulário 656 (offer in compromise).

${ }^{157}$ DACOMO, Natalia de Nardi. Direito Tributário participativo: transação e arbitragem administrativas da obrigação tributária. Tese (Doutorado em Direito), Faculdade de Direito da Pontifícia Universidade Católica de São Paulo, 2008, p. 184-185; Arnaldo Sampaio Godoy, entretanto, destaca a existência de outras normas prevendo a transação em matéria tributária espalhadas em outros capítulos do IRC. (GODOY, Arnaldo Sampaio de Moraes. Transação e Arbitragem no Direito Norte-Americano. In: SARAIVA FILHO, Oswaldo Othon de Pontes; GUIMARÃES, Vasco Branco (Orgs.). Transação e Arbitragem no Âmbito Tributário. Belo Horizonte: Fórum, 2008, p. 417).

${ }^{158}$ Art. 7121 do IRC: "The Secretary is authorized to enter into an agreement in writing with any person relating to the liability of such person (or of the person or estate for whom he acts) in respect of any internal revenue tax for any taxable period".
} 
negociar e celebrar (ou não) tais acordos com os contribuintes ${ }^{159}$. De acordo com a doutrina, estes agentes gozam de ampla margem de discricionariedade para tanto ${ }^{160}$.

Em regra, esses acordos são vinculantes e definitivos. Uma vez concluídos, não podem ser alterados ou modificados, sendo vedado às partes a rediscussão da matéria objeto do acordo e mesmo requerimento de restituição do que se pagou indevidamente ${ }^{161}$. A legislação excetuou, entretanto, algumas hipóteses. Não possuem o atributo da definitividade, os acordos celebrados na hipótese de fraude ou prevaricação, nem tampouco aqueles onde a matéria fática seja apresentada com inexatidão pela parte ${ }^{162}$.

O offer in compromise, previsto no $§ 7122$ do IRC, por sua vez, é uma oferta de pagamento em dinheiro efetuada pelo contribuinte em valor inferior ao seu débito tributário. Em outras palavras, trata-se de uma proposta de transação efetuada pelo contribuinte $^{163}$. A Fazenda poderá aceitar tal proposta quando existirem motivos que justifiquem a redução do valor de sua dívida perante o fisco ${ }^{164}$.

Essa modalidade de acordo é mais abrangente do que a anterior, podendo envolver, inclusive, matéria penal ${ }^{165}$. A competência para celebração dos offers in compromise varia em conformidade com o momento em que este é realizado. Compete ao Secretário do Tesouro celebrar esses acordos antes do encaminhamento do caso para o Departamento de Justiça norte-americano. Após o encaminhamento, a competência passa para o Procurador-Geral ou alguém por ele delegado ${ }^{166}$.

Três são os fundamentos que justificam a aceitação de uma proposta desse gênero

\footnotetext{
${ }^{159}$ DACOMO, Natalia de Nardi. Direito Tributário participativo: transação e arbitragem administrativas da obrigação tributária. Tese (Doutorado em Direito), Faculdade de Direito da Pontifícia Universidade Católica de São Paulo, 2008, p. 185; GODOY, Arnaldo Sampaio de Moraes. Transação e Arbitragem no Direito Norte-Americano. In: SARAIVA FILHO, Oswaldo Othon de Pontes; GUIMARÃES, Vasco Branco (Orgs.). Transação e Arbitragem no Âmbito Tributário. Belo Horizonte: Fórum, 2008, p. 419.

160 DACOMO, Natalia de Nardi. op. cit., p. 185; GODOY, Arnaldo Sampaio de Moraes. op. cit., p. 421; JUNQUEIRA, Helena Marques. Transação Tributária. Tese (Doutorado em Direito), Faculdade de Direito da Pontifícia Universidade Católica de São Paulo, 2009, p. 157.

${ }^{161}$ GODOY, Arnaldo Sampaio de Moraes. op. cit., p. 418.

${ }^{162}$ Conferir a redação da parte final do $\S 7121$ do IRC: "If such agreement is approved by the Secretary (within such time as may be stated in such agreement, or later agreed to) such agreement shall be final and conclusive, and, except upon a showing of fraud or malfeasance, or misrepresentation of a material fact".

${ }^{163}$ DACOMO, Natalia de Nardi. op. cit., p. 186.

164 JUNQUEIRA, Helena Marques. op. cit., p. 158.

${ }^{165}$ GODOY, Arnaldo Sampaio de Moraes. op. cit., p. 422.

${ }^{166}$ Nesse sentido, é a redação do item 'a' do $§ 7122$ do IRC: "The Secretary may compromise any civil or criminal case arising under the internal revenue laws prior to reference to the Department of Justice for prosecution or defense; and the Attorney General or his delegate may compromise any such case after reference to the Department of Justice for prosecution or defense."
} 
pelo fisco: (a) dúvida quanto à responsabilidade do sujeito passivo (doubt as to liability): quando houver controvérsia quanto à existência ou o valor do tributo devido; (b) dúvida quanto à possibilidade de pagamento do contribuinte (doubt as to collectibility): quando o contribuinte não tiver condições financeiras de pagar a totalidade do valor devido ao fisco; e (c) dúvida quanto à efetividade da Administração tributária (effective tax administration): quando a política pública ou a equidade indicarem conveniente ${ }^{167}$.

Juntamente com a proposta de compromisso, o contribuinte deverá apresentar, ao fisco, informações detalhadas sobre sua condição financeira. Ao analisar os termos da proposta oferecida, o fisco levará em consideração uma série de fatores, entre os quais, o patrimônio líquido do contribuinte, bem como sua perspectiva de renda futura ${ }^{168}$. Com base nessas informações, será possível verificar o potencial de pagamento do contribuinte, aceitando ou não a proposta e, eventualmente, fazendo uma contra-proposta.

Ademais, a legislação prevê que sejam divulgados padrões a serem seguidos pelos funcionários do fisco para se determinar se uma oferta de compromisso é adequada e pode ser aceita ${ }^{169}$. Esses padrões levam em consideração as despesas básicas para sobrevivência do contribuinte (basic living expenses). Entretanto, a análise das ofertas de compromisso deverão levar em consideração a situação particular de cada requerente ${ }^{170}$. Caso os padrões definidos não sejam apropriados, os agentes do fisco poderão deixar de utilizálos.

A apresentação da proposta e eventual celebração de um acordo dessa modalidade gera uma série de consequências. Do lado do contribuinte: ele obtém a redução do valor de seu débito tributário; além disso, o fisco não poderá adotar medidas coercitivas sobre o seu patrimônio enquanto pendente a oferta e antes de decorridos 30 dias de sua eventual rejeição. Do lado do fisco: além da arrecadação imediata, o fisco obtém compromisso do contribuinte de que este cumprirá com suas obrigações tributárias pelo prazo de 5 anos;

167 OEI, Shu-Yi. Getting More by Asking Less: Justifying and Reforming Tax Law's Offer-in-Compromise Procedure. p. 1078. Disponível em: <http://papers.ssrn.com/sol3/papers.cfm?abstract_id=1909006>. Acesso em: 10 fev. 2013; DACOMO, Natalia de Nardi. Direito Tributário participativo: transação e arbitragem administrativas da obrigação tributária. Tese (Doutorado em Direito), Faculdade de Direito da Pontifícia Universidade Católica de São Paulo, 2008, p. 186.

${ }^{168}$ WATSON, Camilla E. Tax Procedure and Tax Fraud in a nutshell. [S.L.]: Thompson, 2006 p. 108-109 e 196; DACOMO, Natalia de Nardi. op. cit., p. 187.

169 Conforme a redação do item 'd' (1) do $\S 7121$ do IRC: "The Secretary shall prescribe guidelines for officers and employees of the Internal Revenue Service to determine whether an offer-in-compromise is adequate and should be accepted to resolve a dispute."

170 GODOY, Arnaldo Sampaio de Moraes. Transação e Arbitragem no Direito Norte-Americano. In: SARAIVA FILHO, Oswaldo Othon de Pontes; GUIMARÃES, Vasco Branco (Orgs.). Transação e Arbitragem no Ambito Tributário. Belo Horizonte: Fórum, 2008, p. 423. 
além do mais, durante o prazo da análise do acordo e eventuais recursos interpostos de sua rejeição, o prazo prescricional para a cobrança do crédito tributário fica suspenso ${ }^{171}$.

A experiência norte-americana em relação aos acordos em matéria tributária entre fisco e contribuinte é bastante peculiar. Esta peculiaridade decorre de seu próprio sistema jurídico-tributário. Nesse sistema, o formalismo exacerbado dá lugar a práticas simples que privilegiam os resultados ${ }^{172}$, entre as quais encontra-se a possibilidade de celebração de acordos entre fisco e contribuinte.

Como se vê, a experiência estrangeira dá conta que a transação em matéria tributária já está sendo utilizada por diversos países. Tanto países que têm como base o civil law, como aqueles que tem como base o direito costumeiro já utilizam a transação (ou um instituto análogo) como forma de composição de conflitos com o contribuinte. Apesar desse instrumento não estar isento de críticas, vê-se a experiência em outros países, de uma forma geral, como positiva. Não obstante, é imprescindível que se façam algumas alterações, de forma a melhor adaptar esse instrumento à realidade brasileira.

\footnotetext{
${ }^{171}$ OEI, Shu-Yi. Getting More by Asking Less: Justifying and Reforming Tax Law's Offer-in-Compromise Procedure, p. 1077. Disponível em: <http://papers.ssrn.com/sol3/papers.cfm?abstract_id=1909006>. Acesso em: 10 fev. 2013.

172 JUNQUEIRA, Helena Marques. Transação Tributária. Tese (Doutorado em Direito), Faculdade de Direito da Pontifícia Universidade Católica de São Paulo, 2009, p. 158.
} 


\section{CAPÍTULO II - O FALSO DOGMA DA IMPOSSIBILIDADE DE TRANSAÇÃO EM MATÉRIA DE DIREITO PÚBLICO NO BRASIL}

A questão da possibilidade de transação pela Administração Pública não é uma novidade trazida única e exclusivamente pelo Direito Tributário. Essa discussão envolve também vários outros ramos do Direito Público.

Com efeito, antes de adentrar no estudo do instituto da transação em matéria tributária propriamente dito, será efetuada uma análise desse instituto no âmbito do Direito Público; mais precisamente para saber se Administração Pública pode celebrar acordos com concessões mútuas com particulares e a amplitude de tais transações, notadamente quando se tratar de questões envolvendo Direito Público.

Essa análise é necessária na medida em que que, sendo o Direito Tributário um ramo do Direito Público, a conclusão pela possibilidade de transação pela Administração Pública é premissa para os desenvolvimentos seguintes.

\subsection{Considerações iniciais}

É comum a idéia de que a Administração Pública não pode transigir, pois que seria mera curadora de direitos indisponíveis dos quais seriam titulares toda a coletividade. Nesse sentido, pressupondo a transação concessões mútuas pelas partes, na forma do estabelecido pelo art. 840 do Código Civil, não haveria que se falar em transação pelos entes da Administração Pública, na medida em que estes não poderiam dispor dos direitos dos quais são apenas curadores e/ou gestores.

Não fora isso, outra grande crítica à possibilidade de transação pela Administração consiste em que o instituto da transação somente poderia se dar em relação a direitos patrimoniais de caráter privado, conforme preceitua o art. 841 do Código Civil. Para os que assim entendem, se eventualmente admitida a transação pela Administração Pública, essa somente poderia se dar nas situações em que a Administração atuasse em par de igualdade com o particular.

Para se analisar essas questões, primeiramente, é preciso notar que o exercício de funções públicas pela Administração tem sofrido algumas transformações ao longo dos anos. Conforme visto no capítulo anterior, o Estado cada vez mais deixa de exercer 
funções baseadas em seu poder de autoridade (ius imperium) e passa a exercer suas funções com uma participação maior da coletividade. É o que parte da doutrina denomina de "Administração participativa" ou "Administração consensual"173.

Nesse sentido, Onofre Alves Batista Júnior destaca que a participação da coletividade no desenvolvimento das atividades administrativas (ao invés da imposição de atos unilaterais imperativos pela Administração) tem por finalidade assegurar maior efetividade aos direitos dos cidadãos, garantindo uma maior legitimidade na definição dos interesses públicos tutelados ${ }^{174}$.

A participação dos administrados nas funções estatais é reflexo da evolução do Estado Democrático de Direito ${ }^{175}$. A esse respeito, frise-se que o Estado Democrático é aquele que pressupõe a efetiva participação popular nos rumos da sociedade. Para tanto, não basta o sistema de representatividade, por meio de mandato (participação popular indireta): este é um estágio do Estado Democrático, mas não representa a sua plenitude. Como ensina José Afonso da Silva, o Estado Democrático de Direito é aquele que se funda no princípio da soberania popular, com participação direta e pessoal dos cidadãos na formação dos atos de governo ${ }^{176}$.

É que, melhor do que a representação dos interesses dos cidadãos por seus representantes, é sua participação direta nas atividades estatais (participação popular direta). E, isso pode se dar tanto em relação à função estatal legislativa (e.g. projeto de lei de iniciativa popular, plebiscito, referendum), quanto em relação à função administrativa (e.g. audiências públicas, ação popular), e também em relação à função jurisdicional para resolução de conflitos de interesses entre as partes (e.g. conciliação e transação).

Sobre a Administração consensual, Gustavo Justino de Oliveira destaca que os meios consensuais de Administração ganham cada vez mais importância, especialmente porque são instrumentos de participação dos particulares - envolvidos ou interessados no processo de tomada de decisões administrativas, deixando de lado o caráter de

173 OLIVEIRA, Gustavo Justino de. A Administração Consensual como a nova face da Administração Pública no século XXI: fundamentos dogmáticos, formas de expressão e instrumentos de ação. In: OLIVEIRA, Gustavo Justino de. Direito administrativo democrático. Belo Horizonte: Fórum, 2010, p. 212.

${ }^{174}$ BATISTA JÚNIOR, Onofre Alves. Transações administrativas. São Paulo: Quartier Latin, 2007, p. 462.

${ }^{175}$ Nas palavras de Onofre Alves Batista Júnior, “A própria qualificação que a CRFB/88 realiza do Estado como 'Democrático de Direito', social em seu desiderato, implica a aceitação de instrumentos consensuais que permitam à Administração Pública o cumprimento de tarefas que essa nova concepção impõe." (Ibid., p. 463).

${ }^{176}$ SILVA, José Afonso da. Curso de direito constitucional positivo. São Paulo: Malheiros, 2013, p. 121 et seq. 
imposição e obtendo uma maior aceitação pelos administrados ${ }^{177}$.

E, essa noção de participação do particular na Administração não é de todo nova em nosso ordenamento jurídico. Sobre a atuação crescente dos particulares nos serviços públicos, Helena Marques Junqueira destaca que a privatização dos serviços de telecomunicações, fornecimento de energia e construção de estradas, inclusive por meio das chamadas Parcerias Público-Privadas, contribuiu bastante para isso ${ }^{178}$. Some-se a isso a possibilidade de celebração de contratos de gestão e termos de parceria entre a Administração Pública e particulares sobre outros objetos.

Ademais, já existem, na atualidade, diversos instrumentos de acordos administrativos, podendo-se destacar: (a) a possibilidade de acordo para efetivação da desapropriação (art. 10 do Decreto-lei n 3.365/41); (b) os vários compromissos de ajustamento de conduta $\left(\operatorname{art.} 5^{\circ}, \S 6^{\circ}\right.$, da Lei $n^{\circ} 7.347 / 85$; art. $4^{\circ}$, XXXIX da Lei $n^{\circ}$ 9.961/00; art. 79-A da Lei n 9.605/98); e (c) o compromisso de cessação de prática sob investigação nos processos em trâmite no CADE (art. 85 da Lei n $\left.{ }^{\circ} 12.529 / 2011\right)^{179}$.

Vê-se, portanto, que a transação, como instrumento de solução de controvérsias entre a Administração Pública e o administrado é, em tese, um mecanismo que, assim como outros instrumentos de Direito Administrativo estabelecidos pelo ordenamento jurídico pátrio, está em consonância com o princípio democrático e a noção de administração consensual, permitindo maior participação do jurisdicionado no processo decisório.

Cabe, no entanto, analisar se essa forma de resolução consensual de conflitos entre Administração e administrado se conforma aos princípios de Direito Público, em particular, aos princípios da legalidade, da impessoalidade, da indisponibilidade do interesse público, da discricionariedade, da proporcionalidade, da razoabilidade e da eficiência. E, em caso positivo, se a transação pode se dar em matéria de créditos tributários, o que será efetuado no Capítulo III desse trabalho.

\footnotetext{
177 OLIVEIRA, Gustavo Justino de. A Administração Consensual como a nova face da Administração Pública no século XXI: fundamentos dogmáticos, formas de expressão e instrumentos de ação. In: OLIVEIRA, Gustavo Justino de. Direito administrativo democrático. Belo Horizonte: Fórum, 2010, p. 228.

178 JUNQUEIRA, Helena Marques. Transação Tributária. Tese (Doutorado em Direito), Faculdade de Direito da Pontifícia Universidade Católica de São Paulo, 2009, p. 149.

179 OLIVEIRA, Gustavo Justino de. op. cit., p. 227; GUEDES, Jefferson Carús. Transigibilidade de interesses públicos: prevenção e abreviação de demandas da Fazenda Pública. In: GUEDES, Jefferson Carús et al. (Coords.). Advocacia de Estado: questões institucionais para a construção de um Estado de justiça. Belo Horizonte: Fórum, 2009, p. 256 et seq.
} 


\subsection{Transação perante os princípios de Direito Público}

Para se compreender um instituto e sua compatibilidade com determinado ordenamento jurídico não basta uma análise das regras compreendidas nas leis propriamente ditas. Além de estudar as leis, deve o operador do direito sopesar os princípios informadores de determinado sistema jurídico.

É que, os princípios são as premissas de um sistema, que servem de critério e parâmetro para as demais normas ou leis. Os princípios irradiam seus valores sobre as demais normas, permitindo com que se possa melhor compreender o seu significado. Nesse sentido, pode-se dizer que os princípios são a base de um ordenamento jurídico, servindo ele como alicerce de um sistema normativo ${ }^{180}$.

Paulo Bonavides destaca que uma das principais características dos princípios é o seu alto grau de generalidade e indeterminação. Porém, o referido professor ressalta que, apesar dessas características, a doutrina moderna, majoritariamente, reconhece que os princípios possuem normatividade e que se encontram em posição hierárquica superior às demais normas do ordenamento jurídico, que deverão com eles se conformar ${ }^{181}$.

Portanto, para se analisar a compatibilidade do instituto da transação no âmbito da Administração Pública (e em matéria de Direito Público), faz-se necessário uma análise desse instituto vis-à-vis os princípios de Direito Público expressos e implícitos em nosso ordenamento jurídico, sopesando-os em caso de conflitos.

\subsubsection{Legalidade administrativa}

O princípio da legalidade tem por finalidade proteger os direitos individuais em face do Poder Estatal ${ }^{182}$. Resulta do Estado de Direito. Ao contrário do que se passava nas monarquias absolutistas, onde a atuação do monarca não possuía qualquer espécie de

\footnotetext{
${ }^{180}$ MELLO, Celso Antônio Bandeira de. Curso de direito administrativo. São Paulo: Malheiros, 2013, p. 54.

${ }^{181}$ BONAVIDES, Paulo. Curso de Direito Constitucional. São Paulo: Malheiros, 2006, p. 256 et seq.

${ }^{182}$ Maria Sylvia Zanella Di Pietro afirma que "[...] o direito administrativo nasceu e desenvolveu-se baseado em duas idéias opostas: de um lado o da proteção dos direitos individuais diante do Estado, que serve de fundamento ao princípio da legalidade, um dos esteios do Estado de Direito; de outro lado, o da necessidade de satisfação de interesses públicos, que conduz à outorga de prerrogativas e privilégios para a Administração Pública, quer para limitar o exercício de direitos individuais em benefício do bem-estar coletivo (poder de policia), quer para a prestação de serviços públicos." (DI PIETRO, Maria Sylvia Zanella. O princípio da supremacia do interesse público: sobrevivência diante dos ideais do neoliberalismo. In: DI PIETRO, Maria Sylvia Zanella et al. (Coords.). Supremacia do interesse público e outros temas relevantes do direito administrativo. São Paulo: Atlas, 2010, p. 93).
} 
limites, no Estado de Direito, é a lei que determina as balizas da autuação dos governantes, limitando a atuação estatal. Portanto, no Estado de Direito, a atuação estatal está conformada pelas determinações impostas pela lei ${ }^{183}$.

Não se pode olvidar que a lei é o conjunto de normas emanadas do Poder Legislativo, composto por representantes eleitos pelo povo. Diz-se que o poder estatal está limitado pela manifestação de vontade dos cidadãos. O princípio da legalidade é, assim, o corolário de que "todo poder emana do povo", e de que os seus representantes apenas o exercem em seu nome, conforme as diretrizes legais ${ }^{184}$.

E, se por um lado, o princípio da legalidade estabelece que o particular não será obrigado a fazer ou deixar de fazer alguma coisa senão em virtude de lei (contorno negativo do princípio da legalidade), por outro, este mesmo princípio determina que a Administração Pública somente poderá fazer aquilo que estiver determinado na lei (contorno positivo do princípio da legalidade) ${ }^{185}$.

A lei é, portanto, ao mesmo tempo, uma limitação do poder estatal e o fundamento de validade da atuação deste Estado.

Por conta dessa dupla faceta do princípio da legalidade para a Administração, a liberdade de atuação estatal é muito inferior à liberdade de atuação dos particulares. Enquanto os particulares têm liberdade para contratar ou não, podendo escolher com quem irão contratar e qual o conteúdo do contrato, o administrador público tem não somente a faculdade, mas o dever de fazê-lo, porém poderá/deverá fazê-lo tão somente quando houver lei nesse sentido ${ }^{186}$.

\footnotetext{
183 Celso Antônio Bandeira de Mello explica: “[...] enquanto o princípio da supremacia do interesse público sobre o interesse privado é da essência de qualquer Estado, de qualquer sociedade juridicamente organizada com fins políticos, o da legalidade é específico do Estado de Direito, é justamente aquele que o qualifica e que lhe dá a identidade própria”. E, mais adiante, o emérito professor da Pontifícia Universidade Católica de São Paulo acrescenta: “[...] É, em suma: a consagração da idéia de que a Administração Pública só pode ser exercida na conformidade da lei e que, de conseguinte, a atividade administrativa é atividade sublegal, infralegal, consistente na expedição de comandos complementares à lei." (MELLO, Celso Antônio Bandeira de. Curso de direito administrativo. São Paulo: Malheiros, 2013, p. 102-103).

184 Sobre essa afirmação, Paulo Otero faz contundente crítica, afirmando que, na atualidade, tem havido o fenômeno da transmutação das fontes de legalidade administrativa e das relações entre o poder executivo e o poder legislativo. Conforme o professor da Faculdade de Lisboa, ao invés de haver uma subordinação política e legislativa da Administração (poder executivo) ao legislativo - representando os cidadãos - o que se verifica é uma predeterminação do conteúdo das leis pelo governo, quando de sua submissão à apreciação parlamentar, que se limitará a homologar ou não a decisão legislativa tomada pelo poder executivo. (OTERO, Paulo. Legalidade e Administração Pública: o sentido da vinculação administrativa à juridicidade. Lisboa: Almedina, 2003, p. 517 et seq).

${ }^{185}$ BATISTA JÚNIOR, Onofre Alves. Transações administrativas. São Paulo: Quartier Latin, 2007, p. 465.

${ }^{186}$ Nas palavras de Onofre Alves Batista Júnior: “[...] A Administração Pública não atua no quadro do direito privado portando autonomia privada, mas age com base em normas de organização e de
} 
Pois bem. Considerando que a transação no âmbito administrativo é um acordo de vontades entre a Administração Pública e o particular, sua implementação dependerá necessariamente, no que tange à manifestação de vontade estatal, subsumida ao império da lei, do respeito aos ditames estabelecidos pela lei e pelo direito com um todo, nele incluídos os vários outros princípios de Direito Público.

Onofre Alves Batista Júnior ressalta que, embora o princípio da legalidade tenha aplicação em relação a todas as atuações administrativas, sejam elas unilaterais (atos administrativos) ou consensuais (contratuais), nessas últimas haveria uma maior discricionariedade do administrador ${ }^{187}$. Quer dizer, a Administração gozaria de uma maior margem de valoração de suas condutas quando se estiver diante da celebração de acordos. Porém, essa liberdade deve estar pautada por parâmetros e diretrizes, a serem necessariamente observados pela Administração.

É justamente em razão da existência dessa margem valorativa outorgada ao administrador nas relações consensuais da Administração com o particular que se admite a transação pela Administração Pública, sem que com isso venha a se falar em violação ao princípio da legalidade per se, desde que, evidentemente, respeitados outros limites e princípios de Direito Público.

\subsubsection{Indisponibilidade do interesse público}

O princípio da indisponibilidade do interesse público pela Administração é um dos fundamentos do regime jurídico-administrativo. Serve como base do conjunto de princípios e regras que, em razão de suas peculiaridades, fazem com que esse ramo do direito tenha características próprias e seja estudado em separado dos demais ${ }^{188}$.

Porém, antes de adentrar propriamente no conteúdo do princípio da

competência, que lhe fixam as tarefas administrativas que pode/deve desempenhar, mesmo quando se vale de ferramentas típicas do mundo privado." (BATISTA JÚNIOR, Onofre Alves. Transações administrativas. São Paulo: Quartier Latin, 2007, p. 474).

${ }^{187}$ A esse respeito, inclusive, Onofre Alves Batista Júnior ressalta que o princípio da legalidade teria sido moldado em razão do conceito de ato administrativo (unilateral), cabendo questionamento acerca de sua aplicação em relação ao contrato administrativo (bilateral). No entanto, o professor da Universidade Federal de Minas Gerais conclui que a legalidade deve fundamentar toda e qualquer atuação estatal, uma vez que a conduta administrativa afeta pessoas além daquelas visadas, característica que o referido professor denomina de "multilateralidade". (Ibid., p. 466).

188 Para o referido autor, duas seriam as "pedras de toque" do regime-jurídico administrativo: (a) a supremacia do interesse público sobre o privado; e (b) a indisponibilidade do interesse público pela Administração. (MELLO, Celso Antônio Bandeira de. Curso de direito administrativo. São Paulo: Malheiros, 2013, p. 55-56). 
indisponibilidade do interesse público e suas consequências sobre a transação em matérias envolvendo o Direito Público, faz-se necessária uma pequena digressão sobre o significado de interesse público e sua origem.

Conforme Maria Sylvia Zanella di Pietro, a noção de interesse público remonta à antiguidade greco-romana. Naquela época, embora ainda não se utilizasse a terminologia "interesse público", já era possível diferenciar os interesses gerais da sociedade dos interesses individuais de seus membros ${ }^{189}$.

Posteriormente, na Idade Média, desenvolveu-se a idéia de "bem comum". Tal idéia tinha como fundamento a existência de uma comunidade política, onde se uniam os indivíduos para buscar satisfazer os seus interesses. Esse também era o seu limite, na medida em que o poder político somente poderia ser exercido para satisfazer o bem comum dessa comunidade ${ }^{190}$.

O interesse público como princípio de Direito Público desenvolveu-se durante o Estado Social de Direito, quando houve um crescimento substancial do papel do Estado na sociedade para além das funções ditas regalianas como é o caso da segurança, da justiça e da polícia, tão características do Estado Liberal ${ }^{191}$.

Mas, no que consiste o interesse público?

De acordo com Hector Jorge Escola, uma primeira análise do conteúdo de interesse público deve se dar por meio da fixação do sentido dos termos que compõem essa expressão: "interesse” e "público". Com efeito, interesse seria o valor ou importância que tem uma coisa ou um bem para uma pessoa ou grupo de pessoas, ao passo que público é tudo aquilo que interessa ao Estado ou à comunidade ${ }^{192}$.

A partir dessa idéia inicial, o interesse público poderia ser conceituado como o

\footnotetext{
${ }^{189}$ DI PIETRO, Maria Sylvia Zanella. O princípio da supremacia do interesse público: sobrevivência diante dos ideais do neoliberalismo. In: DI PIETRO, Maria Sylvia Zanella et al. (Coords.). Supremacia do interesse público e outros temas relevantes do direito administrativo. São Paulo: Atlas, 2010, p. 86.

${ }^{190}$ Ibid., p. 87 et seq.

191 Maria Sylvia Zanella di Pietro afirma: “[...] com o crescimento do Estado, os próprios indivíduos passaram a exigir uma atuação do poder público, não só mais para o exercício só das atividades de segurança, polícia e justiça, como ocorria no período do Estado Liberal de Direito, mas também para a prestação de serviços públicos essenciais ao desenvolvimento da atividade individual, em todos os seus aspectos, pondo fim às injustiças sociais geradas pela aplicação dos princípios incorporados pelo Direito Civil. Por outro lado, esse novo Estado prestador de serviços trouxe consigo a prerrogativa de limitar o exercício de direitos individuais, em benefício do bem-estar coletivo, pondo em perigo a própria liberdade individual." (Ibid., p. 92).

192 ESCOLA, Hector Jorge. El Interés Público como Fundamento Del Derecho Administrativo. Buenos Aires: Depalma, 1989, p. 237.
} 
valor preponderante para o conjunto dos membros de uma sociedade. Seu conteúdo transcenderia os interesses de cada um dos indivíduos que a compõem, consistindo no interesse da coletividade em geral. Relaciona-se ao interesse social, enquanto sinônimo de interesse coletivo ${ }^{193}$.

Celso Antônio Bandeira de Mello ressalta, porém, que o interesse público não se dissocia completamente do interesse dos particulares, configurando-se como uma "função qualificada dos interesses das partes" ou, ainda, como "a dimensão pública dos interesses individuais" ${ }^{\prime 194}$.

Com efeito, é a presença de interesses individuais coincidentes e compartidos por um grupo considerável de indivíduos que faz com que surja o interesse público, como consequência do interesse de toda a comunidade, sendo irrelevante a existência de um ente supraindividual por meio do qual haveria a expressão desse interesse ${ }^{195}$.

O interesse público pode ser conceituado, de acordo com Celso Antônio Bandeira de Mello, como "o interesse resultante do conjunto dos interesses que os indivíduos pessoalmente têm quando considerados em sua qualidade de membros da Sociedade e pelo simples fato de o serem" ${ }^{196}$. É , portanto, não o reflexo valorativo geral e total de uma comunidade, mas a expressão de uma maioria.

Como consequência, tem-se que, existirão situações em que o interesse da coletividade não corresponderá necessariamente ao interesse de alguns de seus membros (representados por uma minoria). Nessa hipótese, no entanto, esses indivíduos deverão aceitar e/ou acatar o interesse público escolhido pela maioria dos membros de certa comunidade.

E, é exatamente por ser reflexo dos valores de uma maioria coletiva que o

\footnotetext{
${ }^{193}$ GUEDES, Jefferson Carús. Transigibilidade de interesses públicos: prevenção e abreviação de demandas da Fazenda Pública. In: GUEDES, Jefferson Carús et al. (Coords.). Advocacia de Estado: questões institucionais para a construção de um Estado de justiça. Belo Horizonte: Fórum, 2009, p. 250 et seq.

${ }^{194}$ A esse respeito, o renomado professor destaca que "[...] Seria inconcebível um interesse do todo que fosse, ao mesmo tempo, contrário ao interesse de cada uma das partes que o compõem. Deveras, corresponderia ao mais cabal contrassenso que o bom para todos fosse o mal de cada um, isto é, que o interesse de todos fosse um anti-interesse de cada um." E acrescenta: "Embora seja claro que pode haver um interesse público contraposto a um dado interesse individual, sem embargo, a toda evidência, não pode existir um interesse público que se choque com os interesses de cada um dos membros da sociedade." (MELLO, Celso Antônio Bandeira de. Curso de direito administrativo. São Paulo: Malheiros, 2013, p. 60).

${ }^{195}$ ESCOLA, Hector Jorge. El Interés Público como Fundamento Del Derecho Administrativo. Buenos Aires: Depalma, 1989, p. 238.

${ }^{196}$ MELLO, Celso Antônio Bandeira de. op. cit., p. 62.
} 
interesse público possui supremacia e/ou prevalência sobre o interesse individual ${ }^{197} 198$.

Vê-se, portanto, que o conceito de interesse público (e sua prevalência sobre os interesses individuais) é consequência lógica da própria finalidade de que se reveste o Estado. Tanto isso é verdade que Hely Lopes Meirelles chega a afirmar que o princípio da supremacia do interesse público (ou tão somente "interesse público") pode ser também chamado de princípio da finalidade pública ${ }^{199}$.

Até agora analisamos o conceito de interesse público e, de forma bastante sucinta, a razão de sua prevalência sobre o interesse privado. E o princípio da indisponibilidade do interesse público?

Hely Lopes Meirelles afirma que a indisponibilidade do interesse público decorre da supremacia do interesse público, consistindo em que a Administração Pública não poderia deixar de atender a fins de interesse da coletividade nem, eventualmente, vir a renunciar a poderes conferidos pelo ordenamento jurídico para promover tal tutela, já que não é titular destes direitos ${ }^{200}$.

Diógenes Gasparini, por sua vez, assevera que a indisponibilidade do interesse público significa que os interesses, direitos e bens públicos não se encontram à livre disposição dos órgãos e servidores que compõem a Administração Pública. Estes possuem o papel, tão somente, de curadores ou gestores da coisa pública. Podem eles utilizá-la e administrá-la, mas não podem dela dispor como quiserem. É que esses bens, direitos e interesses seriam, em realidade, de titularidade do Estado ${ }^{201}$.

\footnotetext{
${ }^{197}$ Sobre a questão da prevalência do interesse público sobre o interesse individual, Hector Jorge Escola aponta não existir uma diferenciação qualitativa, senão quantitativa, pois que o primeiro resulta de uma quantidade preponderante de indivíduos. Sendo assim, mais correto seria falar não em superioridade ou supremacia, mas sim em prevalência do interesse público sobre o interesse individual, fundado em que o interesse público é majoritário. (ESCOLA, Hector Jorge. El Interés Público como Fundamento Del Derecho Administrativo. Buenos Aires: Depalma, 1989, p. 242).

${ }^{198}$ Para uma análise crítica do princípio da supremacia do interesse público sobre o privado, conferir BINENBOJM, Gustavo. Da supremacia do interesse público ao dever de proporcionalidade: um paradigma para o direito administrativo. In: BINENBOJM, Gustavo. Temas de direito administrativo e constitucional. Rio de Janeiro: Renovar, 2008, p. 61 et seq. Nesse trabalho, o autor sustenta não ser possível concluir-se, $a$ priori, pela prevalência do interesse público sobre o particular, preconizando que haverá vezes em que o interesse particular deverá prevalecer. Conclui por dizer que deverá haver sempre ponderação dos interesses públicos e particulares em jogo para se chegar à conclusão de qual deverá preponderar na espécie. (BINENBOJM, Gustavo. Da supremacia do interesse público ao dever de proporcionalidade: um paradigma para o direito administrativo. In: BINENBOJM, Gustavo. Temas de direito administrativo e constitucional. Rio de Janeiro: Renovar, 2008, p. 61 et seq).

${ }^{199}$ MEIRELLES, Hely Lopes. Direito Administrativo Brasileiro. São Paulo: Malheiros, 2013, p. 110.

${ }^{200}$ Ibid., p. 110.

${ }^{201}$ GASPARINI, Diógenes. Direito Administrativo. São Paulo: Saraiva, 2012, p. 72.
} 
No mesmo sentido é o posicionamento de José dos Santos Carvalho Filho, para quem a indisponibilidade enfatiza que os bens e interesses públicos não são de titularidade da Administração nem de seus agentes, que gerem e conservam estes em nome da coletividade. O referido professor ressalta que este princípio "parte, afinal, da premissa de que todos os cuidados exigidos para os bens e interesses públicos trazem beneficios para a própria coletividade"202.

Sobre o princípio da indisponibilidade do interesse público, Edmir Netto de Araújo destaca, ainda, que os administradores podem guardar, gerenciar e fiscalizar a coisa pública, mas não possuem os poderes característicos de propriedade de dispor sobre ela e aliená-la. E, acrescenta que, em realidade, não se trata de um poder, mas um dever do administrador de agir no melhor interesse público ${ }^{203}$.

Por essa razão, assevera-se haver necessidade de lei para que a Administração venha a alienar bens, renunciar a direitos e transigir. Também por conta do princípio da indisponibilidade do interesse público que a celebração de contratos administrativos deve ser, em regra, precedida do procedimento licitatório, como forma de se obter a proposta mais vantajosa para a Administração Pública ${ }^{204}$.

É justamente nesse contexto que se insere o instituto da transação pela Administração Pública, mais especificamente, da transação em matéria de Direito Público, que é objeto desse capítulo. A questão, pois, é saber se seria possível transigir?

Para melhor compreender essa questão, importa diferenciar o interesse público primário do interesse público secundário.

Foi dito até aqui, com base nas lições de Celso Antônio Bandeira de Mello, que o interesse público consiste no interesse da coletividade, resultado dos interesses individuais dos membros de determinado corpo social (Estado). Porém, impende distinguir os interesses do Estado enquanto pessoa política (interesses secundários), daquele do Estado enquanto sociedade (interesses primário) ${ }^{205}$.

\footnotetext{
${ }^{202}$ CARVALHO FILHO, José dos Santos. Manual de Direito Administrativo. São Paulo: Atlas, 2013, p. 35.

${ }^{203}$ ARAÚJO, Edmir Netto de. Curso de Direito Administrativo. São Paulo: Saraiva, 2010, p. 74-76.

${ }^{204}$ Note que a necessidade de licitação precedendo a celebração de contratos administrativos pertinentes a obras, serviços, compras e alienações se dá não somente em razão do princípio da indisponibilidade do interesse público, como também em razão dos princípios da igualdade, impessoalidade, probidade administrativa e outros.

205 Ilustrando a diferença entre interesse público primário e secundário, o renomado administrativista aponta que: "[...] o Estado poderia ter interesse em tributar desmensuradamente os administrados, que assim enriqueceria o Erário, conquanto empobrecesse a Sociedade; que, sob igual ótica, poderia ter interesse em pagar valores ínfimos aos seus servidores, reduzindo-os ao nível de mera subsistência.” E, posteriormente
} 
De acordo com Renato Alessi, interesse público primário consiste no complexo de interesses individuais prevalentes em uma determinada organização jurídica coletiva. Por outro lado, o interesse público secundário consiste no interesse pessoal do sujeito administrativo (soggeto amministrativo) ${ }^{206}$.

Assim, pode-se dizer que interesse primário é aquele que resulta dos diversos interesses individuais dos membros de uma determinada coletividade. Em outras palavras, cada sociedade é composta por indivíduos com interesses próprios e na medida em que esses interesses individuais passam a coincidir, tem-se o interesse público primário. Portanto, interesse primário é o interesse público propriamente dito.

De outra parte, o interesse secundário é o interesse da pessoa jurídica que realiza determinada função administrativa, que não necessariamente coincide com o interesse da coletividade, havendo casos, inclusive, em que os interesses são conflitantes. É o caso, por exemplo, de determinado ente político que tem interesse em aumentar o máximo seus tributos ou de pagar o mínimo a seus funcionários.

Essa distinção entre interesse público primário e interesse público secundário existe também como forma de proteção dos indivíduos membros da sociedade contra atos praticados pelas pessoas que agem em nome da Administração Pública. Com isso, evita-se abusos eventualmente cometidos em prol da realização do interesse secundário ou de interesses pessoais de agentes administrativos ${ }^{207}$.

Com efeito, não fora esta distinção entre interesse público primário e secundário, poderia haver abusos por parte daqueles que agem em nome da Administração Pública,

acrescenta: “[....] Teria interesse em pagar valor ínfimo nas desapropriações, isto é, abaixo do justo, inobstante o preceito constitucional. Com todos estes expedientes, muitos dos quais infelizmente (e injustamente) adota, resguardaria ao máximo seu patrimônio, defendendo interesses à moda de qualquer outro sujeito" E, ao final, conclui: "Ocorre que, em todas essas hipóteses estará agindo contra o Direito, divorciado do interesse público, do interesse primário que lhe assiste cumprir." (MELLO, Celso Antônio Bandeira de. Curso de direito administrativo. São Paulo: Malheiros, 2013, p. 67).

206 No original: "[...] soddisfacimento, non sono, si noti bene, semplicemente l'interesse dell'amministrazione intesa come soggetto giuridico a sè stante, sibbene quello che è stato chiamato l'interesse collettivo primario (2), formato dal complesso degli interessi individuali prevalenti in una determinata organizzazione giuridica della colletività, mentre l'interesse del soggetto amministrativo è semplicemente uno degli interesse secondari che si fanno sentire in seno alla collettività." (ALESSI, Renato. Diritto Amministrativo: Le Giurisdizioni Speciali Amministrative. Padova: CEDAM, 1941, p. 151152).

${ }^{207}$ Essa proteção contra abusos cometidos pelos agentes públicos não se relaciona ao interesse público e sua (suposta) prevalência sobre os interesses privados, conforme afirmado por grande parte da doutrina nacional e estrangeira, mas sim aos princípios da moralidade e impessoalidade. (BINENBOJM, Gustavo. Da supremacia do interesse público ao dever de proporcionalidade: um paradigma para o direito administrativo. In: BINENBOJM, Gustavo. Temas de direito administrativo e constitucional. Rio de Janeiro: Renovar, 2008, p. 61 et seq). 
visando à realização de interesses secundários ou, pior, de interesses individuais próprios de seus agentes ${ }^{208}$.

Importa ainda ressaltar que somente os atos praticados em observância ao interesse coletivo (interesse público primário) gozam dos atributos de supremacia em relação aos interesses particulares e devem observância ao princípio da indisponibilidade do interesse público, já explicado anteriormente.

Vê-se, pois, que quando se fala em princípio da indisponibilidade do interesse público como fundamento do regime jurídico-administrativo e do Direito Público, tem-se que ter sempre em mente o conceito de interesse público primário (ou da coletividade) e não o interesse secundário (da pessoa política).

Desta forma, pode-se dizer que os agentes e órgãos públicos não podem dispor de bens e direitos, quando esses forem de interesse da coletividade. E, quem define qual o interesse da coletividade é o próprio ordenamento jurídico. São as leis que irão estabelecer quais são os interesses escolhidos pela coletividade ${ }^{209}$.

Para tanto, deve o jurista interpretar sistematicamente a Constituição e demais leis, para extrair quais interesses podem ser qualificáveis como verdadeiramente públicos num determinado caso, especialmente quando estivermos diante de um aparente conflito de interesses ${ }^{210}$.

Nesse sentido, Jefferson Carús Guedes destaca que uma das maiores dificuldades em se aceitar a transação em matéria de Direito Público consiste no dogma da indisponibilidade do interesse público. E acrescenta que essa dificuldade está intrinsecamente relacionada à vagueza e indeterminação conceitual do termo "interesse público", que necessita da função do intérprete para encontrar o seu conteúdo ${ }^{211}$.

É que, embora o princípio da indisponibilidade do interesse público seja a base do ${ }^{208}$ No original: "[...] l'amministrazione, in quanto mero ente ideológico, può agire soltanto, come si è posto
in rilievo a suo luogo, a mezzo delle persone fisiche preposte ai suoi uffici, persone fisiche le quali, a loro
volta, sono titolari di propri interessi personali, tal che esse potrebbero indirizzare l'attività
amministrativa, facendo uso dei poteri giuridici loro concessi, addirittura alla realizzazione di questi
interessi loro personali, con pregiudizio dell'interesse publico." (ALESSI, Renato Alessi. Diritto
Amministrativo: Le Giurisdizioni Speciali Amministrative. Padova: CEDAM, 1941, p. 153).
${ }^{209}$ Leis (em sentido lato) como sinônimo de normas jurídicas, incluindo a Constituição, as leis (em sentido
stricto) e até os princípios que norteiam um ordenamento jurídico.
${ }^{210}$ MELLO, Celso Antônio Bandeira de. Curso de direito administrativo. São Paulo: Malheiros, 2013, p.
68 -69.
${ }^{211}$ GUEDES, Jefferson Carús. Transigibilidade de interesses públicos: prevenção e abreviação de demandas
da Fazenda Pública. In: GUEDES, Jefferson Carús et al. (Coords.). Advocacia de Estado: questões
institucionais para a construção de um Estado de justiça. Belo Horizonte: Fórum, 2009, p. 250 . 
ordenamento jurídico-administrativo, não possui ele um valor absoluto, perene e imutável. Dependerá das condições políticas, sociais, culturais e econômicas prevalecentes numa determinada época em determinada sociedade. Seu conteúdo, portanto, não é fixo, podendo ser modificado em decorrência da alteração das condições e dos costumes. ${ }^{212}$

Ademais, como conceito jurídico indeterminado que é, o interesse público pressupõe ponderação quando de sua aplicação. Deve-se avaliar o custo-benefício de determinado valor perante os demais valores assegurados pelo ordenamento jurídico de determinado Estado.

Portanto, dizer que o instituto da transação viola, per se, o interesse público não é verdadeiro, devendo-se haver uma análise casuística dos interesses em jogo.

\subsubsection{Impessoalidade}

O princípio da impessoalidade pressupõe que o administrador não poderá dar um tratamento diferenciado a pessoas em situações semelhantes. Impessoal é aquilo "que não pertence a ninguém em particular" ${ }^{213}$. Assim, não pertencendo o interesse público a ninguém em particular, não se pode dar um tratamento especial a qualquer indivíduo.

Diógenes Gasparini assevera que a atividade administrativa deve ser prestada a todos os cidadãos sem discriminação ou favorecimento de pessoa específica. Destaca, também, que a adoção do princípio da impessoalidade objetivou afastar o então tradicional costume praticado na Administração de privilegiar alguns cidadãos em razão de seu prestígio ou porque a eles devia algum favor ${ }^{214}$.

Parte da doutrina considera que a impessoalidade é um aspecto do princípio da $\underline{\text { isonomia }}^{215}$, de acordo com o qual a Administração deverá tratar igualmente pessoas que se encontrem em situações idênticas. Outra parte relaciona a impessoalidade ao princípio

\footnotetext{
${ }^{212}$ No original: "[...] El contenido concreto del interés público puede ser tan variado y diferente, como el que es propio de cualquier interés particular o privado. Dependerá de las condiciones políticas, sociales, económicas, morales y, en general, culturales, reinantes en un país o en un lugar determinado, en un tiempo dado. Por eso mismo, el contenido concreto del interés publico no es fijo o invariable, sino que puede llegar a modificarse, total o parcialmente, como resultado de la alteración de las condiciones y de las costumbres que le han dado origen." (ESCOLA, Hector Jorge. El Interés Público como Fundamento Del Derecho Administrativo. Buenos Aires: Depalma, 1989, p. 245).

${ }^{213}$ Dicionário Aurélio online. Disponível em $<$ http://www.dicionariodoaurelio.com>. Acesso em 12 jun. 2012.

${ }^{214}$ GASPARINI, Diógenes. Direito Administrativo. São Paulo: Saraiva, 2012, p. 62-63.

${ }^{215}$ CARVALHO FILHO, José dos Santos. Manual de Direito Administrativo. São Paulo: Atlas, 2013, p. 2021; MELlO, Celso Antônio Bandeira de. Curso de direito administrativo. São Paulo: Malheiros, 2013, p. 117.
} 
$\underline{\text { da finalidade }}^{216}$, conforme o qual o objetivo do administrador deve ser sempre o interesse público, nunca se podendo privilegiar o interesse particular.

Seja qual for a acepção que se dê ao princípio da impessoalidade (isonomia ou finalidade), a observância a esse princípio é de suma importância para a lisura de eventual procedimento de transação praticado pela Administração. É que, conforme visto acima, havendo administrados em situações idênticas, não poderá o administrador privilegiar alguns em detrimento de outros quando da celebração de acordos para compor litígios.

É justamente essa uma das fortes críticas efetuadas por Eurico Diniz de Santi em relação à transação em matéria tributária, que será tratada no capítulo seguinte ${ }^{217}$. Em contraponto, é possível sustentar que a transação não somente encontra respaldo na finalidade do instituto que é colocar fim ao litígio, como também no fato de que a isonomia pressupõe justamente a análise das circunstâncias de cada caso concreto. Ademais, existem em nosso ordenamento mecanismos de controle e responsabilização dos agentes públicos, capazes de conter eventual violação à impessoalidade.

\subsubsection{Discricionariedade}

Já vimos que, no Estado Democrático de Direito, a Administração Pública encontra limites a sua atuação no princípio da legalidade. Ademais, também já foi dito que o conceito de legalidade para a Administração é muito mais restrito do que o conceito de legalidade para os particulares, resultando que o administrador público somente pode fazer aquilo que está permitido pela lei.

No entanto, ao contrário do que, eventualmente, possa se pensar, o princípio da legalidade não inibe a outorga de poderes com certa carga de discricionariedade ao administrador. Isso porque, haverá situações em que, por intermédio de uma lei, é possível que os cidadãos entendam por bem outorgar poderes para que o administrador efetue determinada escolha. É justamente aí que se situa o princípio da discricionariedade (ou poder discricionário).

De acordo com José dos Santos Carvalho Filho, o poder discricionário está centrado no fato de que, ainda que a lei possa restringir a liberdade de escolha do

${ }^{216}$ CARVALHO FILHO, José dos Santos. Manual de Direito Administrativo. São Paulo: Atlas, 2013, p. 20; MEIRELLES, Hely Lopes. Direito Administrativo Brasileiro. São Paulo: Malheiros, 2013, p. 95-96.

217 SANTI, Eurico Marcos Diniz de. Transação e arbitragem no Direito Tributário: paranóia ou mistificação? In: FERRAZ, Roberto (Coord). Principios e limites da tributação 2 - Os princípios da ordem econômica e a tributação. São Paulo: Quartier Latin, 2009, p. 624-626. 
administrador, não pode ela prever todas as suas condutas, havendo hipóteses em que a própria lei lhe permitirá a valoração da sua conduta. Nessas situações, caberá ao administrador escolher, entre as várias condutas possíveis, aquela mais conveniente e oportuna, levando sempre em consideração o interesse público ${ }^{218}$.

No mesmo sentido, Edmir Netto de Araújo assevera que a discricionariedade é a faculdade conferida pela lei para que o administrador escolha, entre duas ou mais soluções, aquela mais conveniente e oportuna ao caso concreto. E, acrescenta que a discricionariedade dá uma maior liberdade de atuação ao administrador, flexibilizando as decisões e, com isso, permitindo a adequada realização do interesse público ${ }^{219}$.

Assim, em relação ao princípio da discricionariedade e à transação pela Administração Pública, pode-se diferenciar duas hipóteses: (i) uma, em que a lei delimita todos os contornos do suposto acordo, retirando qualquer margem valorativa por parte da Administração, cabendo ao administrado aderir aos seus termos ou não; e (ii) outra, em que a lei dá uma certa margem de discricionariedade de formatação do acordo pela Administração Pública ${ }^{220}$.

Todavia, mesmo diante dessa segunda hipótese, onde se verifica o poder discricionário da Administração, o administrador público não estará livre para acordar o que bem entender como se um particular fora. É que, em razão do que já fora dito sobre o princípio da legalidade, sempre haverá parâmetros e diretrizes previamente estabelecidos pela lei que deverão ser observados pelo administrador quando da escolha da sua conduta. Fala-se, pois, em limitação ao poder discricionário.

Com efeito, apesar de existirem situações em que se permite ao administrador uma margem de valoração na escolha de suas condutas, conforme a conveniência e oportunidade, deve sempre haver uma adequação entre os meios e os fins da conduta administrativa. É justamente nos princípios da proporcionalidade e razoabilidade que se encontram esses limites, conforme será analisado a seguir.

218 CARVALHO FILHO, José dos Santos. Manual de Direito Administrativo. São Paulo: Atlas, 2013, p. 51 et seq.

219 ARAÚJO, Edmir Netto de. Curso de Direito Administrativo. São Paulo: Saraiva, 2010, p. 85.

${ }^{220}$ Onofre Alves Batista Júnior salienta: “[...] Por vezes, à Administração nada cabe valorar e a decisão já vem marcada em lei específica, que delineia toda a situação concreta e a solução. A decisão já vem marcada em 'lei-medida' específica que retira a possibilidade de valoração por parte do administrador." (BATISTA JÚNIOR, Onofre Alves. Transações administrativas. São Paulo: Quartier Latin, 2007, p. 508). 


\subsubsection{Proporcionalidade e razoabilidade}

Embora existam diferenças conceituais entre eles, o princípio da proporcionalidade (de origem alemã) está intrinsecamente relacionado ao princípio da razoabilidade (de origem anglo-saxônica). Têm em comum o fato de servirem de critérios para impor limites à atuação dos Poderes Legislativo e Executivo. E, é exatamente em vista dessa relação intrínseca entre os princípios da razoabilidade e proporcionalidade que se optou por tratá-los conjuntamente nesse tópico ${ }^{221}$.

Como destaca Paulo Bonavides, apesar do princípio da proporcionalidade não ser novo, foi ele redescoberto nos últimos séculos, tendo ganhado importância ainda maior da doutrina e jurisprudência nos últimos 50 anos, para se transformar em princípio geral de direito com aplicação não somente no âmbito do Direito Administrativo, mas também no Direito Constitucional ${ }^{222}$.

Pode-se dizer que o princípio da proporcionalidade objetiva estabelecer uma relação entre os fins e os meios utilizados. Consiste na utilização de meios adequados e não excessivos para a realização de determinada finalidade. Trata-se, pois, de instrumento de controle de excessos praticados por administradores.

Nesse diapasão, José dos Santos Carvalho Filho destaca que o principal fundamento da proporcionalidade é o excesso de poder e sua finalidade a de conter atos, decisões e condutas de agentes públicos, que ultrapassem os limites adequados para os fins objetivados pela Administração ${ }^{223}$.

Sobre a abrangência do princípio da proporcionalidade, Pierre Muller destaca que ele constitui, ao mesmo tempo, uma obrigação (de fazer uso dos meios adequados) e uma vedação (do uso de meios desproporcionados) ${ }^{224}$. Nesse sentido, a doutrina ressalta que a proporcionalidade é composta por 3 elementos ou acepções:

\footnotetext{
${ }^{221}$ Acerca da relação entre esses dois princípios, Edmir Netto de Araújo ressalta que o princípio da razoabilidade deve ser entendido como proporcionalidade dos meios e decisões em relação aos fins objetivados. E acrescenta que: “[...] diante de um caso concreto, uma decisão será 'irrazoável' quando, por exemplo, o sacrifício de um direito ou interesse do administrado não seja proporcional, ou aceitável, em relação ao fim de interesse público que se pretende atingir, ou se a decisão é manifestamente inadequada para alcançá-lo". (ARAÚJO, Edmir Netto de. Curso de Direito Administrativo. São Paulo: Saraiva, 2010, p. 81).

${ }^{222}$ BONAVIDES, Paulo. Curso de Direito Constitucional. São Paulo: Malheiros, 2006, p. 399.

${ }^{223}$ CARVALHO FILHO, José dos Santos. Manual de Direito Administrativo. São Paulo: Atlas, 2013, p. 42.

${ }^{224}$ MULLER, Pierre. Le principe de la proportionnalité. Revue de Droit Suisse. Basel: [s.n.], 1978, vol. 97, apud BONAVIDES, Paulo. op. cit., p. 398.
} 
i) adequação: o meio ou a medida empregada deve ser capaz de obter o fim desejado, isto é, deve ser apta para a obtenção do fim a que se destina (também chamado por Paulo Bonavides de "pertinência" ou "aptidão"225);

ii) necessidade: o meio ou a medida empregada não deverá exceder os limites necessários à conservação dos interesses que almeja, causando o menor prejuízo possível aos envolvidos, isto é, entre os meios hábeis deve-se optar pelo menos gravoso; e

iii) proporcionalidade (em sentido estrito): as vantagens a serem obtidas com o meio ou a medida empregada devem superar as desvantagens; quer dizer, a escolha deve trazer maiores benefícios do que prejuízos.

Levando em consideração os elementos acima mencionados, pode-se concluir que haverá violação ao princípio da proporcionalidade quando os meios utilizados para determinado fim não forem adequados ou quando houver manifesta desproporção entre os meios utilizados e os fins almejados ${ }^{226}$.

O princípio da razoabilidade, por sua vez, estabelece padrões para a conduta do administrador. Por meio dele impõem-se a moderação, o comedimento e a sensatez daquele que administra a res publica. Ao tratar do princípio da razoabilidade, José dos Santos Carvalho Filho afirma que a conduta do administrador deve se pautar dentro de "standards de aceitabilidade" 227.

No entanto, a qualidade do que seja razoável ou aceitável é bastante subjetiva, de tal forma que aquilo que é razoável para uma pessoa, pode não sê-lo para outra. E, mesmo que se tenha como parâmetro o homem médio, ainda assim, seria bastante difícil estabelecer se uma determinada conduta se enquadraria dentro dos padrões de razoabilidade ou aceitabilidade decorrentes desse princípio.

Desta feita, verifica-se que tanto o princípio da proporcionalidade como o princípio da razoabilidade servem de mecanismos que oferecem balizas à atividade administrativa, limitando, porém não eliminando, a liberdade do administrador na valoração da sua escolha. É por essa razão que esses princípios são importantes no estudo

\footnotetext{
${ }^{225}$ BONAVIDES, Paulo. Curso de Direito Constitucional. São Paulo: Malheiros, 2006, p. 396.

${ }^{226}$ Ibid., p. 393.

${ }^{227}$ CARVAlHO FILHO, José dos Santos. Manual de Direito Administrativo. São Paulo: Atlas, 2013, p. 40.
} 
da transação administrativa.

Em atenção a tais princípios, o administrador público não poderá agir como bem entender, devendo observar os critérios estabelecidos em lei e, na margem de liberdade que lhe é concedida pela lei, respeitar os princípios do interesse público, da impessoalidade, da razoabilidade e proporcionalidade.

Esses princípios são importantes no estudo da transação administrativa na medida em que oferecem um direcionamento quanto à atuação do administrador, nessa matéria que revela grande carga de discricionariedade.

\subsubsection{Eficiência}

A possibilidade de transação pela Administração Pública fundamenta-se, também, no princípio da eficiência, erigido a princípio constitucional a partir da $\mathrm{EC}^{\circ} 19 / 98$, que o acrescentou no rol do art. 37, caput, da Constituição Federal de $1988^{228}$.

Também denominado de qualidade do serviço, a adoção pelo legislador constituinte derivado do princípio da eficiência na Administração Pública é consequência da transformação, nas últimas décadas, do modelo de Administração burocrática, para o modelo de Administração gerencial ${ }^{229}$.

Esse princípio foi introduzido em razão do crescente descontentamento da sociedade contra a deficiente e ineficiente prestação de serviços pela Administração e seus delegados. Teve ele por objetivo orientar a Administração Pública a prestar um serviço de melhor qualidade aos seus cidadãos, buscando garantir o respeito da Administração em face dos direitos e prerrogativas de seus administrados.

Alexandre de Moraes ressalta que "o administrador público precisa ser eficiente, ou seja, deve ser aquele que produz o efeito desejado, que dá bom resultado”. E destaca, entre as características que compõem o princípio da eficiência: (a) o direcionamento da atividade ao bem comum; (b) a imparcialidade; (c) a neutralidade; (d) a transparência; (e)

\footnotetext{
228 Alexandre de Moraes ressalta, porém, que mesmo antes de sua alçada a princípio constitucional, a jurisprudência do Superior Tribunal de Justiça já reconhecia o status desse princípio entre os princípios que regem a Administração Pública, conforme RMS n ${ }^{\circ}$ 5.590/95-DF, STJ, $6^{\text {a }}$ Turma, citado pelo autor. (MORAES, Alexandre de. Direito Constitucional. São Paulo: Atlas, 2013, p. 339).

229 Sobre a transformação da Administração Pública burocrática em Administração Pública gerencial, conferir PEREIRA, Luiz Carlos Bresser. Da administração pública burocrática à gerencial. In: PEREIRA, Luiz Carlos Bresser; SPINK, Peter. Reforma do Estado e da Administração Pública gerencial. Rio de Janeiro: Fundação Getúlio Vargas, 2006, p. 237 et seq.
} 
a busca da qualidade; (f) a desburocratização; e (g) a participação da população nos serviços públicos ${ }^{230}$.

Conforme visto acima, vê-se que o princípio da eficiência, além de preconizar uma maior qualidade na prestação de serviços, com redução de seu custo e aumento da rapidez da prestação de serviços, pressupõe uma maior participação dos cidadãos. É justamente nesse contexto, como reflexo do princípio da eficiência, que se insere o instrumento da transação pela Administração Pública.

É que, como já mencionado, o alto custo e lentidão dos processos judiciais têm acarretado a inadequada ou insatisfatória solução de litígios pelo Poder Judiciário, o que favoreceria e até privilegiaria soluções alternativas de controvérsia, conforme já destacado na introdução deste trabalho. Nesse sentido, Onofre Alves Batista Júnior destaca que o princípio da eficiência determina a busca pela melhor forma de solução de litígios que poderá, por muitas vezes, ser por meio da transação ${ }^{231}$.

José dos Santos Carvalho Filho, assevera que foi exatamente nesse contexto que foi editada a Emenda Constitucional no 45/04, que acrescentou o inciso LXXVIII ao art. $5^{\circ}$ da $\mathrm{CF} / 88$, estabelecendo a razoável duração do processo aos direitos fundamentais do cidadão, contra a demora dos processos judiciais (e administrativos), e cujo conteúdo é o princípio da eficiência no acesso à justiça ${ }^{232}$.

E, nesse diapasão, convém destacar que a transação é mais célere que a solução convencional de litígios pelo Judiciário, pois que prescinde de diferentes instâncias e depende tão somente da vontade das partes para se chegar a uma solução. Além disso, pressupõe a participação democrática do administrado na composição do litígio (autocomposição), um dos cânones do princípio da eficiência.

Sobre a participação dos administrados nos procedimentos administrativos, Onofre Alves Batista Júnior ressalta que esse mecanismo, resultado do Estado Democrático de Direito, ao mesmo tempo em que proporciona maior garantia dos direitos dos cidadãos,

\footnotetext{
${ }^{230}$ O professor da Universidade de São Paulo conclui ainda que: “Assim, princípio da eficiência é aquele que impõe à Administração Pública direta e indireta e seus agentes a persecução do bem comum, por meio do exercício de suas competências de forma imparcial, neutra, transparente, participativa, eficaz, sem burocracia e sempre em busca da qualidade, primando pela adoção de critérios legais necessários para a melhor utilização possível dos recursos públicos, de maneira a evitar-se desperdícios e garantir-se uma maior rentabilidade social". (MORAES, Alexandre de. Direito Constitucional. São Paulo: Atlas, 2013, p. 341 et seq).

${ }^{231}$ BATISTA JÚNIOR, Onofre Alves. Transações administrativas. São Paulo: Quartier Latin, 2007, p. 462.

${ }^{232}$ CARVALHO FILHO, José dos Santos. Manual de Direito Administrativo. São Paulo: Atlas, 2013, p. 31.
} 
assegura a legitimidade das atuações consensuais da Administração, donde se insere a transação administrativa ${ }^{233}$.

Há quem afirme que a transação poderia eventualmente macular a eficiência em seu aspecto de transparência e imparcialidade, em razão da prática corriqueira de corrupção e tráfico de influência no seio da Administração Pública, estando o Judiciário (ao menos em princípio) livre desses males que assolam o Executivo.

Entretanto, existem mecanismos de controle do administrador. A esse respeito, inclusive, Alexandre de Moraes destaca que a possibilidade de perda do cargo pelo servidor público mediante avaliação de desempenho periódica é, nada mais, nada menos, do que uma decorrência do princípio da eficiência no âmbito da Administração ${ }^{234}$.

Ademais, se é verdade que existem escândalos de corrupção na Administração Pública, não é menos verdade que isso ocorre nas três esferas de governo (Executivo, Legislativo e Judiciário), sendo que a impossibilidade de transacionar não significa, necessariamente, que tais desvios de conduta não ocorrerão.

A transação como instrumento de resolução de conflitos pela Administração Pública está em consonância com o princípio da eficiência e o princípio da razoável duração dos processos judiciais e administrativos. Ademais, por se tratar de mecanismo de autocomposição, permite uma participação mais efetiva do administrado, como consequência da preconizada soberania popular.

Vê-se, portanto, que em observância aos princípios de Direito Público acima referidos, a Administração Pública não somente pode, como deve transigir em algumas situações. Nesse sentido, inclusive, convém destacar que a Administração Pública, há muito, já vem celebrando acordos com os administrados, mesmo em matéria de Direito Público, conforme se verá em mais detalhes a seguir.

\subsection{Hipóteses de transação no Direito Público}

Viu-se até aqui que o instituto da transação pela Administração Pública é possível, mesmo quando envolva matéria de Direito Público. Os princípios da legalidade e indisponibilidade do interesse público não são obstáculos para que isso ocorra, servindo

\footnotetext{
${ }^{233}$ BATISTA JÚNIOR, Onofre Alves. Transações administrativas. São Paulo: Quartier Latin, 2007, p. 463 et seq.

${ }^{234}$ MORAES, Alexandre de. Direito Constitucional. São Paulo: Atlas, 2013, p. 346.
} 
de diretriz para tanto. Ademais, a Administração Pública deverá observar os limites de seu poder discricionário, tendo como parâmetros a proporcionalidade e a razoabilidade e como objetivo a eficiência administrativa.

Tanto isso é verdade que vários são os institutos mencionados pela doutrina moderna que colocam em cheque o dogma da impossibilidade de transação pela Administração Pública (no âmbito do Direito Público). Corroborando tal posição, Jefferson Carús Guedes destaca os seguintes normativos como reflexo da tendência atual da transigibilidade pela Administração Pública ${ }^{235}$ :

- Lei $\mathrm{n}^{\circ} 6.825 / 80$ (art. $5^{\circ}$ ): que previa a possibilidade de transação nas causas inferiores a 100 ORTNs, salvo de natureza fiscal e relativas ao patrimônio imobiliário da União (revogada);

- Lei $\mathrm{n}^{\mathrm{o}}$ 8.197/91 (art. $1^{\circ}$ ): que admitia a transação para extinção de processos, nas causas de interesse da União, suas autarquias, fundações e empresas públicas federais, limitadas a Cr\$300.000,00 (revogada);

- Lei ${ }^{\circ}$ 9.099/95 (art. 76, \& $4^{\circ}$ ): que permite a transação em matéria de ação penal pública para os crimes considerados de menor potencial ofensivo, matéria essa considerada no passado como indisponível;

- Lei $n^{\circ}$ 9.469/97 (art. $1^{\circ}$ ): que estende a possibilidade de transação para causas de até R \$ 50.000,00 (alterada pela MP 449/2008);

- Lei ${ }^{\circ} 10.259 / 01$ (art. $10, \S$ único): que permite a transação em matéria administrativa, inclusive tributária, nas causas inferiores a 60 saláriosmínimos, independentemente de autorização individual ${ }^{236}$.

Além das hipóteses de transação acima mencionadas, que têm em comum a característica de ocorrerem perante o Poder Judiciário - daí porque chamadas de modalidades judiciais -, outras existem que prescindem da homologação do Judiciário, podendo ocorrer durante o processo (para resolver o litígio) ou mesmo antes da instauração de eventual processo (para prevenir eventual litígio). É o caso da:

\footnotetext{
${ }^{235}$ GUEDES, Jefferson Carús. Transigibilidade de interesses públicos: prevenção e abreviação de demandas da Fazenda Pública. In: GUEDES, Jefferson Carús et al. (Coords.). Advocacia de Estado: questões institucionais para a construção de um Estado de justiça. Belo Horizonte: Fórum, 2009, p. 256 et seq.

${ }^{236}$ Essa questão será objeto de análise específica no item 3.5.4, no capítulo que trata da transação em matéria tributária propriamente dita.
} 
- Lei $\mathrm{n}^{\circ} 7.347 / 85$ (art. $5^{\circ}, \S 6^{\circ}$ ): que permite a hipótese de transação de interesses públicos com o fim de prevenir litígios ou colocar fim a eles por meio de termo de ajustamento de conduta (TAC);

- Lei n $^{\circ}$ 12.529/11 (art. 85): que permite a celebração de compromissos de cessação de prática de infração à ordem econômica sob investigação no âmbito do Sistema Brasileiro de Defesa da Concorrência;

- Lei no 9.961/00 (art. 4, XXXIX): que possibilita à ANS a celebração de termo de compromisso de ajuste de conduta com as operadoras ou prestadoras de serviço de saúde;

- Lei n $^{\circ}$ 9.605/98 (art. 79-A): que prevê a hipótese de celebração de termo de compromisso (TC) em matéria ambiental pelos integrantes do SISNAMA e pessoas consideradas poluidoras; e

- Resolução $n^{\circ} 333 / 08$ (art. $1^{\circ}$ ): que permite a celebração de termo de compromisso de ajustamento de conduta (TCAC) entre a ANEEL e suas concessionárias, permissionárias e autorizadas ${ }^{237}$.

A possibilidade de celebração de acordos (transação) entre a Administração e o administrado não é nova em nosso ordenamento. De certa forma, já era prevista no art. 10, do Decreto-lei $\mathrm{n}^{\circ} 3.365 / 41$, que permitia ao administrador, no curso do procedimento de desapropriação, determinar o valor da justa indenização ao expropriado (é o que se denomina de "transação expropriatória"). Com isso, evita-se o processo judicial para esses fins, em consonância com a celeridade e a eficiência ${ }^{238}$.

Além disso, não é demais lembrar que, embora não existam muitos julgados em relação à possibilidade de transação pela Administração, a esparsa jurisprudência existente sobre o tema acena no sentido de permitir que a transação se realize quando assim indicar o interesse público. Nesse sentido, há precedente do STF que reconheceu, ainda que em caso isolado, a possibilidade de transação pela Administração quando o

\footnotetext{
${ }^{237}$ Jefferson Carús Guedes destaca ainda a possibilidade de celebração de acordos (termos de ajustamento de conduta) no âmbito do Ministério da Educação (Lei $n^{\circ}$ 10.861/04) e no âmbito da ANTT (Resolução ${ }^{\circ}$ 442/04), bem como de acordo (termo de ajustamento de gestão) no âmbito do controle interno da Administração pelos Tribunais de Contas. (GUEDES, Jefferson Carús. Transigibilidade de interesses públicos: prevenção e abreviação de demandas da Fazenda Pública. In: GUEDES, Jefferson Carús et al. (Coords.). Advocacia de Estado: questões institucionais para a construção de um Estado de justiça. Belo Horizonte: Fórum, 2009, p. 264 et seq).

${ }^{238}$ BATISTA JÚNIOR, Onofre Alves. Transações administrativas. São Paulo: Quartier Latin, 2007, p. 460.
} 
interesse público for atendido pelo administrador ${ }^{239}$.

Em resumo, o instituto da transação coaduna-se com os anseios de participação da sociedade no processo decisório. Além disso, a transação em matéria de Direito Público é plenamente possível, estando de acordo com os princípios que regem a Administração Pública, cabendo destacar já existirem mecanismos que se assemelham à transação em nosso ordenamento jurídico, inclusive, em matéria de Direito Público. Enfim, é falso o dogma de que a Administração não pode transacionar em matéria de Direito Público.

239 É o caso da decisão do Supremo Tribunal Federal, proferida nos autos do RE n⿳ $253.885 / \mathrm{MG}$, de relatoria da Min. Ellen Gracie - Ementa: "Poder Público. Transação. Validade. Em regra, os bens e o interesse público são indisponíveis, porque pertencem à coletividade. É, por isso, o Administrador, mero gestor da coisa pública, não tem disponibilidade sobre os interesses confiados à sua guarda e realização. Todavia, há casos em que o princípio da indisponibilidade do interesse público deve ser atenuado, mormente quando se tem em vista que a solução adotada pela Administração é a que melhor atenderá à ultimação desse interesse. [...]." BRASIL. Supremo Tribunal Federal. Recurso Extraordinário nº. 253.885/MG. Relator: Ministra Ellen Gracie. Brasília. J. em: 04 jun. 2002. Disponível em : <http://www.stf.jus.br/portal/jurisprudencia/listarJurisprudencia.asp?s1=\%28253885\%2ENUME\%2E+OU+ 253885\%2EACMS\%2E\%29\&base=baseAcordaos\&url=http://tinyurl.com/ardscmt>. Acesso em: $11 \mathrm{mar}$. 2012. 


\section{CAPÍTULO III - TRANSAÇÃO EM MATÉRIA TRIBUTÁRIA NO BRASIL}

No Capítulo I deste trabalho foi analisada a maneira como a transação tributária está inserida no contexto das transformações ocorridas no Direito Tributário, sendo a prática de transigir uma das perspectivas contemporâneas desse ramo do Direito. Ainda, demonstrou-se que a transação tributária já faz parte da experiência de outros países.

No Capítulo II, o tema transação aproxima-se do ordenamento jurídico pátrio, primeiramente, ainda no ramo mais amplo do Direito Público. A intenção foi a de demonstrar que o dogma de que não seria possível efetuar transação em matéria de Direito Público no Brasil encontra-se superado.

Nesse ponto, convém trazer um esclarecimento: as particularidades do Direito Tributário impõem um exame diverso do instituto da transação vis-à-vis esse ramo específico do direito. Tal análise difere em parte daquela efetuada no Capítulo II, que focou na possibilidade de transação pela Administração em matéria de Direito Público.

A necessidade de uma análise específica para o Direito Tributário decorre da existência de um regime jurídico próprio aplicável à matéria tributária, inclusive com menção expressa no CTN ao instituto da transação. Serão, sobretudo, nesses aspectos que se concentrará a análise da transação nesse Capítulo III.

Com efeito, serão feitas, primeiramente, algumas considerações iniciais em relação à transação tributária no Brasil (item 3.1). Após, serão analisados os pressupostos da transação tributária em conformidade com o art. 171 do CTN (item 3.2). Em seguida, examinar-se-ão os possíveis conflitos entre a transação tributária e o ordenamento pátrio (item 3.3). Somente então serão analisados os principais desafios da transação tributária no contexto brasileiro (item 3.4). Finalmente, será abordada a experiência no direito interno, no âmbito estadual e nos Juizados Especiais Federais (item 3.5).

\subsection{Considerações iniciais sobre a transação tributária no Brasil}

Antes de adentrar nas especificidades do instituto da transação tributária, são necessárias algumas considerações iniciais a fim de: esclarecer a origem do instituto no Direito Civil e suas peculiaridades nesse ramo, bem como os possíveis reflexos no Direito 
Tributário (item 3.1.1); evidenciar a controvérsia acerca da natureza contratual ou não do instituto (item 3.1.2); analisar como o instituto da transação tributária enquadra-se em nosso ordenamento e quais as consequências desse enquadramento (item 3.1.3); e, destacar a relação entre a transação e outros institutos tributários previstos no ordenamento pátrio (item 3.1.4).

\subsubsection{A origem do instituto no Direito Civil e seus possíveis reflexos no Direito Tributário}

A transação não é um instituto novo, já sendo possível encontrá-la desde à época do Direito Romano ${ }^{240}$. Era (e ainda é) uma forma alternativa para composição de litígios a que recorriam as partes para evitar os riscos e as incertezas de uma demanda ou a demora de uma eventual lide. Assim é que, como afirma Sílvio Rodrigues, na transação, as partes "decidem abrir mão, reciprocamente, de algumas vantagens potenciais, em troca da tranquilidade que não têm"241.

A exemplo do que ocorria em outros países, a transação era considerada, na vigência do Código Civil de 1916, por grande parte da doutrina, como sendo um instrumento de natureza contratual. Entretanto, parcela minoritária questionava tal classificação, na medida em que, diferentemente do que aconteceu em outros países, o codificador brasileiro teria colocado esse instituto entre os modos de extinção das obrigações, sendo para esta parte da doutrina um ato jurídico ${ }^{242}$.

Seguindo a linha do Código Civil francês e do Código Civil italiano de 1942, o Projeto de Código de Obrigações de 1965, elaborado por Caio Mário da Silva Pereira, já

\footnotetext{
${ }^{240}$ DINIZ, Maria Helena Diniz. Curso de Direito Civil Brasileiro: teoria das obrigações contratuais e extracontratuais. São Paulo: Saraiva, 2013, v. 3, p. 628; JUNQUEIRA, Helena Marques. Transação Tributária. Tese (Doutorado em Direito), Faculdade de Direito da Pontifícia Universidade Católica de São Paulo, 2009, p. 55.

${ }^{241}$ RODRIGUES, Silvio. Direito civil: dos contratos e das declarações unilaterais da vontade. São Paulo: Saraiva, 2004, v. 3, p. 368.

${ }^{242}$ Ibid., p. 368-369. Ainda sobre essa questão, Natalia de Nardi Dacomo destaca que, apesar da transação já estar prevista em nosso ordenamento jurídico há bastante tempo, sua natureza jurídica era objeto de controvérsia. Nesse sentido, ressalta que a transação já se encontrava prevista no ordenamento brasileiro, no Decreto $\mathrm{n}^{\circ} 2.318$, de 22 de dezembro de 1858 . Destaca, ainda, que a transação inseria-se no Código Civil de 1916, na Parte Geral das Obrigações, como modalidade de extinção das relações obrigacionais. Conclui, assim, fazendo um apanhado da doutrina nacional e estrangeira e das divergências conceituais existentes, que a transação era anteriormente considerada não como negócio jurídico (contrato), mas como "ato jurídico pelo qual as partes, por meio de concessões recíprocas, extinguiam as obrigações litigiosas ou duvidosas". (DACOMO, Natalia de Nardi. Direito Tributário participativo: transação e arbitragem administrativas da obrigação tributária. Tese (Doutorado em Direito), Faculdade de Direito da Pontifícia Universidade Católica de São Paulo, 2008, p. 96 et seq).
} 
propunha a alteração de sua capitulação ${ }^{243}$. Entretanto, somente com o advento do novo Código Civil, em 2002, é que essa discussão ficou de todo superada. Isso porque este diploma normativo tratou da transação expressamente entre as modalidades de contratos, disciplinando-a como tal ${ }^{244}$.

Atualmente, a transação encontra-se disciplinada a partir do art. 840 do atual Código Civil brasileiro ${ }^{245}$. Trata-se de um negócio jurídico bilateral (de natureza contratual), que visa a extinguir obrigações litigiosas ou duvidosas ${ }^{246}$. Em outras palavras, é um acordo que resulta de negociações efetuadas entre as partes interessadas tendo por finalidade acabar com a controvérsia existente, pondo fim às incertezas de determinada relação jurídica.

Nessa linha, Silvio Rodrigues destaca os seguintes elementos da transação: (a) o acordo entre as partes, decorrente da própria natureza contratual do instituto; (b) a existência de relações controvertidas e a intenção de lhes pôr termo, destacando a necessidade da existência de dúvida sobre certa relação jurídica (res dubia); e (c) o recurso a concessões recíprocas para alcançar tal escopo, isto é, que cada uma das partes envolvidas abra mão de parte dos direitos que acredita ter ${ }^{247}$.

Mas não é tão somente para colocar fim a controvérsias previamente existentes que a transação se destina no âmbito do Direito Civil. É que, conforme se observa da redação do art. 840 do atual Código Civil, as partes poderão, mediante concessões mútuas, utilizar a transação tanto para terminar um litígio já existente, como também para evitar que eventual litígio futuro se instaure entre as partes. A transação teria, desse modo, também, uma finalidade preventiva.

No Direito Civil, a transação é, portanto, um instrumento jurídico para a composição amigável dos conflitos entre as partes interessadas, em que cada qual abre mão de parte de suas pretensões, com o objetivo de prevenir ou terminar um litígio. Por essa razão, Maria Helena Diniz assevera que a transação é o "negócio jurídico bilateral, pelo qual as partes interessadas, fazendo-se concessões mútuas, previnem ou extinguem

\footnotetext{
${ }^{243}$ PEREIRA, Caio Mário da Silva. Instituições de Direito Civil: contratos. Rio de Janeiro: Forense, 2012, v. 3, p. 467.

${ }^{244}$ RODRIGUES, Silvio Rodrigues. Direito civil: dos contratos e das declarações unilaterais da vontade. São Paulo: Saraiva, 2004, v. 3, p. 369.

${ }^{245}$ Art. 840. É lícito aos interessados prevenirem ou terminarem o litígio mediante concessões mútuas.

${ }^{246}$ MONTEIRO, Washington de Barros; MALUF, Carlos Alberto Dabus; SILVA, Regina Beatriz Tavares da. Curso de Direito Civil: Direito das Obrigações $-2{ }^{a}$ parte. São Paulo: Saraiva, 2013, v. 5, p. 448.

${ }^{247}$ RODRIGUES, Silvio. op. cit., p. 372 et seq.
} 
obrigações litigiosas ou duvidosas" ${ }^{248}$.

No entanto, o objeto desse negócio jurídico encontra limites. Não é toda e qualquer relação jurídica que pode ser transacionada. É que, como destaca Pontes de Miranda, há de se exigir a transacionabilidade do interesse em questão ${ }^{249}$. Nesse sentido, o Código Civil de 2002, em seu art. 841, limitou o objeto da transação, dispondo que "somente quanto aos direitos patrimoniais disponíveis de caráter privado se admite a transação"250. Esse dispositivo restringiu a transação aos direitos patrimoniais disponíveis de caráter privado.

Esse é um dos fundamentos ao qual se apegam aqueles contrários à possibilidade de transação em matéria tributária. E a razão é simples: os créditos tributários não são créditos de natureza privada e seriam indisponíveis por sua própria natureza, na medida em que as autoridades administrativas estariam obrigadas a lançá-los e cobrá-los por força do disposto no $\mathrm{CTN}^{251}$. Com efeito, uma das questões que se coloca é, pois, saber qual seria o alcance exato desse dispositivo, para assim ajudar a entender se ele teria efetivamente afastado da transação os créditos tributários.

De acordo com Silvio Rodrigues, esse dispositivo afastou da transação: os bens fora do comércio e aquelas questões que interessam à ordem pública. Disso decorre que não poderiam ser objeto de transação os direitos personalíssimos, as coisas inalienáveis, as questões de direito de família (e.g. guarda de filhos), bem como aquelas relações que, embora apresentem um aspecto patrimonial, interessam mais diretamente à ordem pública (e.g. a questão de alimentos - que verse não sobre o quantum, mas sobre o direito aos alimentos propriamente dito $)^{252}$.

Embora não adote exatamente a mesma classificação em relação aos direitos que se encontram excluídos da transação, Caio Mário da Silva Pereira segue as mesmas diretrizes, dispondo que a transação está restrita aos direitos patrimoniais, não podendo as partes transigirem quanto aos direitos não patrimoniais, como é o caso das questões

${ }^{248}$ DINIZ, Maria Helena Diniz. Curso de Direito Civil Brasileiro: teoria das obrigações contratuais e extracontratuais. São Paulo: Saraiva, 2013, v. 3, p. 629.

${ }^{249}$ MIRANDA, Pontes de. Tratado de Direito Privado, Parte Especial, Tomo XXV. Atualização de Nelson Nery Jr.; Rosa Maria de Andrade Nery. São Paulo: Revista dos Tribunais, 2012, p. 179.

${ }^{250}$ Em realidade, dispositivo semelhante já constava do Código Civil de 1916, que previa em seu art. 1035 que: "Só quanto a direitos patrimonias de caracter privado se permite a transação".

${ }^{251}$ Sobre a questão da obrigatoriedade do lançamento e cobrança do crédito tributário, conferir item 3.3.2 deste trabalho.

${ }^{252}$ RODRIGUES, Silvio. Direito civil: dos contratos e das declarações unilaterais da vontade. São Paulo: Saraiva, 2004, v. 3, p. 375. 
envolvendo direitos de família (e.g. legitimidade de filiação, validade do casamento, regime de bens); quanto às questões envolvendo matéria de ordem pública; nem quanto às coisas que se encontrem fora do comércio ${ }^{253}$.

Rubens Miranda de Carvalho, por sua vez, entende que esse dispositivo deve ser interpretado em consonância com o disposto no art. 852, também do Código Civil de 2002, que trata de outro instituto afim, qual seja, o compromisso. Com efeito, à semelhança do que ocorre com esse outro instituto do Direito Civil, estariam excepcionadas da transação "as questões de estado, de direito pessoal de família e outras que não tenham o caráter estritamente patrimonial"254.

Verifica-se, pois, que o disposto no art. 841 do Código Civil teve por finalidade excluir da transação as questões envolvendo direitos personalíssimos, direito de família, questões que interessam à ordem pública, bem como eventuais outros direitos de natureza não patrimonial. De igual modo, não parece que esse dispositivo possa per se ter por consequência excluir da transação os créditos tributários, tampouco as matérias de Direito Público em geral. Nem podia ser diferente, pois que introduzido no Código Civil, que cuida das relações entre particulares. O ramo do Direito Público que rege a relação é que estabelecerá se pode ou não haver, quanto a esse, transação e quais as condições ${ }^{255}$.

Finalmente importa salientar que, embora o art. 841 do Código Civil aplique-se exclusivamente às relações privadas, esse dispositivo pode servir de exemplo para se interpretar o cabimento da transação em outros ramos do Direito. É que, conforme visto no Capítulo II, nada impede que haja transação também em matéria de Direito Público. Desta forma, seja qual for o ramo do direito (inclusive o tributário), a transação poderá ocorrer em relação aos direitos patrimoniais, desde que, evidentemente, estes sejam disponíveis. Cabe ao ramo do direito específico estabelecer se (e em quais condições) a transação pode se realizar ${ }^{256}$.

${ }^{253}$ PEREIRA, Caio Mário da Silva. Instituições de Direito Civil: contratos. Rio de Janeiro: Forense, 2012, v. 3, p. 468.

${ }^{254}$ CARVALHO, Rubens Miranda de. Transação Tributária, Arbitragem e outras formas convencionadas de solução de lides tributárias. São Paulo: Juarez de Oliveira, 2008, p. 17 et seq.

${ }^{255}$ DACOMO, Natalia de Nardi. Direito Tributário participativo: transação e arbitragem administrativas da obrigação tributária. Tese (Doutorado em Direito), Faculdade de Direito da Pontifícia Universidade Católica de São Paulo, 2008, p. 121.

${ }^{256}$ Quanto à (in)disponibilidade do crédito tributário - que decorre da obrigatoriedade do lançamento e cobrança do crédito tributário - como empecilho (ou permissivo) à transação tributária no ordenamento jurídico pátrio, conferir item 3.3.2 infra. 


\subsubsection{Controvérsia acerca da natureza contratual do instituto}

Diferentemente do que ocorre no âmbito do Direito Civil, onde pacificou-se o entendimento de que a transação possui natureza contratual, inserindo-se como modalidade de contrato no Código Civil de 2002, no âmbito do Direito Tributário, a natureza jurídica da transação é bastante controvertida.

Tal controvérsia não se restringe ao nosso ordenamento jurídico. Vicenzo Busa destaca que na Itália também se discute a mesma questão em relação ao accertamento con adesione, sustentando alguns que se trata de um ato unilateral, com a participação do contribuinte, enquanto que outros propugnam pela natureza contratual do instituto ${ }^{257}$. Jean Lamarque, por sua vez, sustenta que na França a transaction teria caráter eminentemente contratual, sobretudo em razão do que se depreende dos julgados sobre o assunto ${ }^{258}$. Esse também é o posicionamento de Túlio Rosembuj em relação à transação tributária no Direito espanhol ${ }^{259}$.

A doutrina brasileira, aparentemente, nunca se debruçou profundamente sobre a questão da natureza contratual ou de ato jurídico unilateral da transação em matéria tributária propriamente dita. Aliomar Baleeiro, baseando-se no dispositivo que tratava da transação no Código Civil de 1916, rechaçava a natureza contratual do instituto, asseverando sua natureza de ato jurídico, tendo em vista que extinguia ou modificava obrigações, mas não as criava. Porém, o prestigiado autor e ex-Ministro da Suprema Corte brasileira reconhecia a existência de opiniões de prestígio em sentido contrário ${ }^{260}$.

Conforme visto no item anterior, recentemente, a transação civil teve sua capitulação alterada pelo Código Civil de 2002, passando a ser expressamente considerada como modalidade contratual e acabando com a controvérsia existente sobre sua natureza jurídica naquele ramo do direito. Questão que se coloca, por conta disso, é saber como seria enxergada a natureza jurídica da transação em matéria tributária após a nova conceituação atribuída pelo Direito Civil.

\footnotetext{
${ }^{257}$ BUSA, Vincenzo. Gli instituti deflativi del contenzioso nell'esperienza italiana: a experiência italiana sobre transação e conciliação em matéria tributária e demais modalidades alternativas de solução de controvérsias fiscais: In: TÔRRES, Heleno Taveira (Coord.). Direito Tributário Internacional Aplicado Volume V, São Paulo: Quartier Latin, 2008, p. 533.

${ }^{258}$ LAMARQUE, Jean; NÉGRIN, Olivier; AYRAULT, Ludovic. Manuel Droit fiscal général, Paris: Lexis Nexis, 2011, p. 440.

${ }^{259}$ ROSEMBUJ, Tulio. La Transacción Tributaria. Barcelona: Atelier, 2000, p. 10.

${ }^{260}$ BALEEIRO, Aliomar. Direito Tributário Brasileiro. 12. ed. rev., atual. e ampl. (atualizada por Misabel Abreu Machado Derzi). Rio de Janeiro: Forense, 2013, p. 1324-1325.
} 
Em artigo recente tratando da transação tributária, Heleno Taveira Tôrres enfatiza que o acordo transacional celebrado entre fisco e contribuinte não tem natureza de contrato, mas de "típico ato administrativo", por meio do qual Administração e contribuinte chegam à solução consensual do litígio ${ }^{261}$. Arnaldo Godoy, por sua vez, sustenta que a transação tributária lembraria o conceito de contrato fiscal aparente de José Casalta Nabais, tendo natureza de ato administrativo unilateral e não verdadeiro contrato $^{262}$. Também corrobora a natureza não contratual da transação tributária, Natália Dacomo, para quem o instituto "é ato administrativo participativo"263. Helena Marques Junqueira, entretanto, defende que a transação tributária tem sim natureza de contrato ${ }^{264}$.

A discussão acerca da natureza contratual ou não do instituto da transação em matéria tributária em nosso sistema jurídico não parece ter ganhado força nem importância. Talvez, porque esse instituto tenha sido ainda pouco estudado por nossos doutrinadores; talvez, simplesmente, porque tenha sido capitulado como forma de extinção do crédito tributário no CTN. De qualquer forma, ao que parece, prevalece o posicionamento segundo o qual a transação tributária, no ordenamento jurídico brasileiro, não possui natureza contratual stricto sensu, mas de mero ato administrativo.

Seja como for, mesmo para os defensores da natureza não contratual da transação tributária, forçoso reconhecer que não se trata de um simples ato unilateral, mas de ato unilateral em que se admite uma certa participação do contribuinte. Nesse sentido, a transação tributária seria reflexo do "contratualismo fiscal" lato sensu. Quer dizer, um instrumento que permite a negociação entre a Administração fiscal e os contribuintes em matéria tributária. Esse mecanismo insere-se no contexto de melhora das relações entre fisco e contribuinte.

Enfim, tenha ou não natureza contratual stricto sensu, o instituto da transação em

${ }^{261}$ TÔRRES, Heleno Taveira. Princípio da segurança jurídica e transação em matéria tributária. Os limites da revisão administrativa dos acordos tributários. In: SARAIVA FILHO, Oswaldo Othon de Pontes; GUIMARÃES, Vasco Branco (Org.). Transação e Arbitragem no Âmbito Tributário. Belo Horizonte: Fórum, 2008, p. 313.

${ }^{262}$ GODOY, Arnaldo Sampaio de Moraes. Transação Tributária: introdução à justiça fiscal consensual. Belo Horizonte: Fórum, 2010, p. 60. A respeito da classificação de contratos fiscais por José Casalta Nabais, conferir item 1.3.1 deste trabalho. Note a esse respeito que, para o professor português, a transação tributária encontra-se entre o que ele denomina de "verdadeiros contratos fiscais" (NABAIS, José Casalta. Contratos Fiscais: reflexões acerca da sua admissibilidade. Coimbra: Coimbra, 1994, p. 104 et seq).

263 DACOMO, Natalia de Nardi. Direito Tributário participativo: transação e arbitragem administrativas da obrigação tributária. Tese (Doutorado em Direito), Faculdade de Direito da Pontifícia Universidade Católica de São Paulo, 2008, p. 115.

264 JUNQUEIRA, Helena Marques. Transação Tributária. Tese (Doutorado em Direito), Faculdade de Direito da Pontifícia Universidade Católica de São Paulo, 2009, p. 81. 
matéria tributária foi tratado, no ordenamento jurídico tributário brasileiro, como forma ou modalidade de extinção do crédito tributário. Será, pois, em vista dessa característica específica, que se analisará o instituto no item a seguir.

\subsubsection{A transação tributária como forma de extinção do crédito tributário}

Inicialmente prevista nos arts. 104 e 210 do Anteprojeto de CTN proposto por Rubens Gomes de Sousa ${ }^{265}$, a transação tributária foi posteriormente tratada nos arts. 118 e 136 do Projeto de Código Tributário Nacional ${ }^{266}$. Atualmente, a transação tributária encontra-se prevista no art. 156 do CTN, que enumera as diversas formas (também denominadas hipóteses ou modalidades) de extinção do crédito tributário, tendo sido disciplinada no art. 171 do mesmo diploma normativo.

Forma ou modalidade de extinção do crédito tributário é qualquer ato ou fato que tenha o condão de libertar o sujeito passivo (devedor) da sujeição em que se encontra em relação ao sujeito ativo (credor), fazendo desaparecer o direito deste contra aquele ${ }^{267}$. São as formas de se fazer romper o vínculo jurídico de um contribuinte para com o físco; vínculo este surgido quando da prática de ato ou fato descrito na norma tributária como hipótese de incidência do tributo (fato gerador ou fato jurídico tributário).

Muito embora o art. 156 do CTN tenha tratado das formas de extinção do crédito tributário, pode-se dizer que os eventos ou situações elencadas nesse dispositivo legal põem termo também à obrigação tributária propriamente dita. Isso porque, a obrigação que nasce com a ocorrência do fato gerador tributário, constituí-se em crédito tributário a

265 “Art. 104. Nenhum tributo será instituído ou majorado a não ser por lei tributária. Parágrafo único. Compete ainda exclusivamente à lei tributária [...] IV - autorizar a remissão de créditos tributários ou permitir seja autorizada a transação a seu respeito.”; “Art. 210. A lei tributária poderá, por disposição expressa, permitir que seja autorizada a transação total ou parcial quanto ao crédito tributário, no curso de processo administrativo ou judicial. Parágrafo único. A transação será proposta em cada caso, em expediente reservado, pelo representante da Fazenda Pública no processo, à mais alta autoridade administrativa competente para dele conhecer, ou à mais alta autoridade do Ministério Público competente, e será autorizada pela referida autoridade sempre que, a seu juízo, o prosseguimento do processo seja desfavorável, inconveniente ou inútil aos interesses da Fazenda Pública.” (BRASIL. Ministério da Fazenda. Trabalhos da Comissão Especial do Código Tributário Nacional. Rio de Janeiro, 1954, p. 318-319).

266 “Art. 118. Extinguem o crédito tributário: I. O pagamento; II. A transação; III. A remissão; IV. A prescrição e a decadência [...].”; “Art. 136. É facultado aos sujeitos ativo e passivo da obrigação tributária celebrar transação que, mediante concessões mútuas, importe em terminação de litígio e consequente extinção do crédito tributário. Parágrafo único. A lei tributária indicará a autoridade competente para celebrar a transação e as formalidades a serem observadas em cada caso." (BRASIL. Ministério da Fazenda. Trabalhos da Comissão Especial do Código Tributário Nacional. Rio de Janeiro, 1954, p. 54-59).

${ }^{267}$ SOUSA, Rubens Gomes de. Compêndio de Legislação Tributária. Rio de Janeiro: Financeiras, 1960, p. 91. 
partir do seu respectivo lançamento, momento em que se torna liquida e exigível.

Nesse particular, Luís Eduardo Schoueri pontua que o crédito tributário decorre da obrigação. A partir do lançamento, é que se identifica a obrigação e se quantifica o valor devido pelo contribuinte, tornando-a exigível. Em consequência, quando se fala em extinção do crédito, examina-se a extinção da própria obrigação tributária ${ }^{268}$.

Helena Marques Junqueira pondera, com base nas lições de Luciano Amaro, que o mais correto talvez fosse falar em extinção da obrigação tributária. Isso porque, na sua visão, existem casos previstos no CTN como modalidades de extinção do crédito em que o crédito propriamente dito jamais existiu, como é o caso da decadência, em que o fisco perde o direito de efetuar o lançamento - constituindo o crédito - devido a sua inércia ${ }^{269}$.

Seja como for, o CTN tratou dessas situações como modalidades de "extinção do crédito tributário", enumerando-as no art. 156 do CTN.

O crédito tributário é, em regra, extinto pelo adimplemento da obrigação tributária, que ocorre por meio do pagamento ou pelos modos pelos quais este se traduz, como é caso da conversão do depósito em renda e da consignação em pagamento ${ }^{270}$. Essas seriam, pois, as formas naturais de extinção do crédito tributário.

Ao lado destas modalidades, existem outras previstas em lei. O legislador nacional colocou a transação tributária entre essas outras modalidades, juntamente com a compensação, a remissão, a prescrição, a decadência, o pagamento antecipado, a decisão administrativa ou judicial irreformável, etc ${ }^{271}$, cada qual com peculiaridades específicas.

\footnotetext{
${ }^{268}$ SCHOUERI, Luís Eduardo. Direito Tributário. São Paulo: Saraiva, 2013, p. 584. Sobre a questão da natureza do lançamento, o referido autor destaca que: “[...] a 'constituição' do crédito não implica seja o lançamento condição para que surja o vínculo jurídico entre sujeito ativo e passivo; com o lançamento, a obrigação ganha feição de 'crédito', já que passa a ser exigível". E prossegue o professor: "Nesse sentido, o lançamento declara a existência de uma obrigação tributária e, fazendo-o, constitui um crédito [...]" Mais adiante em sua obra, ao tratar das modalidades de extinção do crédito tributário, o professor da Universidade de São Paulo destaca que: “[...] uma vez nascida a obrigação tributária, como o fato jurídico tributário, ela persiste até que seja extinta [...]. Aliás o próprio Código Tributário Nacional deixa claro que se confundem ambos os fenômenos, ao declarar, no $\S 1^{\circ}$, do art. 113, que a obrigação tributária 'extingue-se juntamente com o crédito dela decorrente'. Daí, pois, buscar a extinção do crédito ou da obrigação, implica estudar um único fenômeno." (Ibid., p. 609-610).

269 JUNQUEIRA, Helena Marques. Transação Tributária. Tese (Doutorado em Direito), Faculdade de Direito da Pontifícia Universidade Católica de São Paulo, 2009, p. $92-93$.

${ }^{270}$ SAKAKIHARA, Zuudi. Código Tributário Nacional Comentado: Doutrina e Jurisprudência, artigo por artigo, inclusive ICMS e ISS. In: FREITAS, Vladimir Passos de (Coord.). São Paulo: Revista dos Tribunais, 2011, p. 704 et seq.

${ }^{271}$ Art. 156. Extinguem o crédito tributário:

I - o pagamento;

II - a compensação;

III - a transação;
} 
Questão controvertida em relação à transação como modalidade de extinção do crédito tributário diz respeito ao efetivo momento em que o crédito se considera extinto.

Apesar da literalidade do dispositivo, parte da doutrina considera que a celebração da transação per se não tem o condão de extiguir o crédito tributário. Somente daria início ao procedimento que culminaria com sua extinção. De acordo com essa corrente, a extinção do crédito somente ocorreria quando do efetivo cumprimento das obrigações pactuadas quando da transação e pagamento dos valores devidos ${ }^{272}$.

De outro lado, há quem defenda que a transação teria por efeito imediato a extinção do crédito tributário. Essa corrente não faz qualquer referência à necessidade do cumprimento das condições pactuadas na transação ou seu pagamento para que o crédito tributário se extingua ${ }^{273}$. A esse respeito, há quem entenda, inclusive, que a celebração da transação faria surgir uma nova obrigação, resultante da transação. Esse o entendimento de Luís Eduardo Schoueri, para quem "O raciocínio deve ser claro: a transação implica novação. Ela extingue o crédito tributário, por força do artigo 171 do Código Tributário Nacional. O que surge em seu lugar é um novo crédito, resultado da transação"274.

Finalmente, parece que o mais adequado seria considerar que a celebração da transação já seria capaz de extinguir o crédito, porém, tão somente, em relação à parcela do crédito a que as partes abriram mão ao transacionar; o remanescente somente seria extinto quando do cumprimento dos termos e condições pactuados na transação ${ }^{275}$.

\footnotetext{
(...) (grifos acrescentados)

${ }^{272}$ Esse o entendimento de Paulo de Barros Carvalho. Segundo o autor: "Mas é curioso verificar que a extinção da obrigação não se dá propriamente por força das concessões recíprocas, e sim do pagamento. $\mathrm{O}$ processo de transação tão somente prepara o caminho para que o sujeito passivo quite sua dívida, promovendo o desaparecimento do vínculo" (CARVALHO, Paulo de Barros. Curso de Direito Tributário. São Paulo: Saraiva, 2012, p. 540). Em sentido semelhante, manifestou-se Heleno Taveira Tôrres, para quem: "A transação, per se, não extingue o crédito; é simples mecanismo de resolução de conflitos que se presta para pôr fim ao litígio, mediante composição das partes [...]. O pagamento sim extinguirá o crédito, não a transação pura e simplesmente" (TÔRRES, Heleno Taveira. Princípio da segurança jurídica e transação em matéria tributária. Os limites da revisão administrativa dos acordos tributários. In: SARAIVA FILHO, Oswaldo Othon de Pontes; GUIMARÃES, Vasco Branco (Org.). Transação e Arbitragem no Âmbito Tributário. Belo Horizonte: Fórum, 2008, p. 305).

${ }^{273}$ Esse parece ser o posicionamento de Natalia Dacomo, para quem "[...] Entendemos que a consequência da introdução da norma individual e concreta da transação no ordenamento é a extinção da obrigação tributária veiculada pelo lançamento." (DACOMO, Natalia de Nardi. Direito Tributário participativo: transação e arbitragem administrativas da obrigação tributária. Tese (Doutorado em Direito), Faculdade de Direito da Pontifícia Universidade Católica de São Paulo, 2008, p. 118).

${ }^{274}$ SCHOUERI, Luís Eduardo. Direito Tributário. São Paulo: Saraiva, 2013, p. 624

${ }^{275}$ Esse o posicionamento de Hugo de Brito Machado, segundo quem "É razoável, todavia, dizer-se que a transação extingue o crédito tributário na parte em que a Fazenda abriu mão, concedeu."(MACHADO, Hugo de Brito. In: SARAIVA FILHO, Oswaldo Othon de Pontes; GUIMARÃES, Vasco Branco (Orgs.). Transação e Arbitragem no Direito Tributário. Belo Horizonte: Forum, 2008, p. 118). Essa também parece ser a conclusão a que chega Heleno Taveira Tôrres, ao preceituar que: "Decerto que tal menção no rol das
} 
Porém, mesmo nessa hipótese, ainda restaria a questão de se saber se a extinção da parcela do crédito tributário a que as partes abriram mão se daria sob condição resolutória do posterior cumprimento do acordo ou não. Em outras palavras, resta saber se descumprido o acordo, restaura-se a parcela do crédito original que foi extinta ou não.

Em conclusão, o CTN tratou da transação como modalidade de extinção do crédito tributário, enumerando-a em seu art. 156 e disciplinando-a em seu art. 171. Não esclareceu, porém, o momento em que se daria tal extinção, divergindo a doutrina a esse respeito: para alguns, a extinção se dá quando da celebração da transação, enquanto que, para outros, só quando do cumprimento das condições pactuadas. Essa controvérsia é resolvida pelas alterações legislativas propostas, conforme se examinará no Capítulo IV.

\subsubsection{Similitudes e diferenças em relação a outros institutos do Direito Tributário: parcelamento, remissão, anistia e outros}

Conforme já analisado, a transação em matéria tributária encontra-se no ordenamento pátrio entre as causas de extinção do crédito tributário. Está prevista no art. 156, III do CTN, tendo sido disciplinada no art. 171 do mesmo diploma legal. Apesar da transação tributária possuir um regime jurídico próprio em nosso ordenamento jurídico, é bastante comum associar a transação a outros institutos do Direito Tributário, devido às semelhanças existentes entre eles. Estes institutos são, principalmente: a moratória, o parcelamento, a remissão, a anistia e a denúncia espontânea.

A moratória está prevista no art. 151, I do CTN, tendo sido disciplinada nos arts. 152 e seguintes deste mesmo Código. Encontra-se entre as hipóteses de suspensão da exigibilidade do crédito tributário. Trata-se de técnica de política fiscal ${ }^{276}$, que consiste na dilação do prazo originalmente previsto na legislação para o cumprimento da obrigação tributária. Em outras palavras: é a concessão de uma prorrogação ou de um novo prazo para o cumprimento da obrigação tributária pelo sujeito passivo ${ }^{277}$. Enquanto pendente esse novo prazo, não pode a Administração promover medidas constritivas sobre o

causas extintivas das obrigações tributárias só tem cabimento se entendermos a transação no contexto da extinção da pretensão tributária sobre o quanto foi condedido pela Administração tributária, com respeito às concessões (recíprocas) dos contribuintes." (TÔRRES, Heleno Taveira. Princípio da segurança jurídica e transação em matéria tributária. Os limites da revisão administrativa dos acordos tributários. In: SARAIVA FILHO, Oswaldo Othon de Pontes; GUIMARÃES, Vasco Branco (Org.). Transação e Arbitragem no Âmbito Tributário. Belo Horizonte: Fórum, 2008, p. 310).

276 COÊLHO, Sacha Calmon Navarro. Curso de Direito Tributário Brasileiro. Rio de Janeiro: Forense, 2012 , p. 693.

277 SCHOUERI, Luís Eduardo. Direito Tributário. São Paulo: Saraiva, 2013, p. 601. 
patrimônio do sujeito passivo.

Pode ser concedida em caráter geral ou individual. Ambas dependem de lei. Porém, a moratória em caráter geral decorre da própria lei, enquanto que a moratória em caráter individual é concedida por despacho da autoridade administrativa, desde que autorizada por lei (art. 152, II, “b”, do CTN). A lei em questão deve ser editada pelo ente competente para instituir o tributo ou, excepcionalmente, pela União em relação aos tributos de competência dos demais entes políticos. Além disso, a lei concessiva da moratória poderá delimitar sua aplicação à determinada região do território, uma classe ou uma categoria de sujeitos passivos (art. 152, § único, do CTN).

Diversos são os requisitos para a concessão da moratória, destacando-se: (a) a estipulação de novo prazo para pagamento das obrigações tributárias, não podendo ser concedida por prazo indeterminado; (b) as condições da concessão do favor em caráter individual; e, sendo o caso (c) os tributos a que se aplica, o número de prestações e as garantias que devem ser fornecidas (art. 153, do CTN). Ademais, normalmente, a moratória pressupõe que os créditos tributários estejam definitivamente constituídos na data da lei ou do despacho que a conceder (art. 154, do CTN). Excepcionalmente, porém, admite-se que a lei concessiva da moratória disponha diferentemente ${ }^{278}$.

A legislação pátria dispôs expressamente que a moratória concedida em caráter individual não gera direito adquirido e será revogada sempre que se constatar que seu beneficiário não preenchia os requisitos ou não satisfazia (ou deixou de satisfazer) as condições para o seu gozo (art. 155, do CTN). No entanto, o dispositivo concedeu tratamento diferenciado aos efeitos dessa revogação (melhor qualificada por alguns de anulação) $)^{279}$. Deveras, a depender da existência de dolo ou simulação na conduta do sujeito passivo, a legislação prevê um tratamento diferenciado em relação à imposição de penalidades, bem como à contagem do prazo prescricional ${ }^{280}$.

Enfim, a moratória diferencia-se da transação. Enquanto aquela é causa suspensiva da exigibilidade do crédito tributário, consistente na dilação do prazo de vencimento da obrigação tributária, esta é causa extintiva do crédito tributário ${ }^{281}$.

\footnotetext{
${ }^{278}$ CARVALHO, Paulo de Barros. Curso de Direito Tributário. São Paulo: Saraiva, 2012, p. 519.

${ }^{279}$ SCHOUERI, Luís Eduardo. Direito Tributário. São Paulo: Saraiva, 2013, p. 604.

${ }^{280}$ Para uma análise crítica dessa diferença de tratamento, conferir COÊLHO, Sacha Calmon Navarro. Curso de Direito Tributário Brasileiro. Rio de Janeiro: Forense, 2012, p. 694-695.

${ }^{281}$ Sobre os pressupostos da transação em matéria tributária em conformidade com o art. 171 do CTN, conferir item 3.2 deste trabalho.
} 
O parcelamento é também causa de suspensão da exigibilidade do crédito tributário. Encontra-se previsto no art. 151, VI do CTN, tendo sido regulamentado pelo art. 155-A do mesmo diploma legal. Esses dispositivos foram introduzidos pela LC $\mathrm{n}^{\mathrm{o}}$ 104/2001. Até então, não havia previsão expressa do parcelamento no CTN. Entretanto, isso não impedia sua utilização pelos diversos entes políticos. É que, o parcelamento era considerado como espécie de moratória em que se prevêem pagamentos parcelados, aplicando-se o art. 151, I do $\mathrm{CTN}^{282}$. Não à toa, a legislação pátria dispõe aplicar-se ao parcelamento, subsidiariamente, as disposições relativas à moratória.

Somente pode ser concedido parcelamento na forma e condições estabelecidas por lei específica (art. 155-A, caput, do CTN). Ademais, estabeleceu-se que, em regra, o parcelamento não implica em exclusão dos juros e multas (art. 155-A, § único, do CTN). Tal previsão visa a assegurar que aquele que parcelou seus débitos não tenha um tratamento mais benéfico do que aquele que cumpriu suas obrigações no prazo legal ${ }^{283}$. Este dispositivo acabou com antiga discussão acerca da possibilidade de a parte beneficiar-se das vantagens da denúncia espontânea quando confessasse seus débitos no parcelamento, mas efetuasse o pagamento em parcelas ${ }^{284}$.

Posteriormente, com o advento da LC $\mathrm{n}^{\mathrm{o}} 118 / 2005$, foram introduzidos dois novos dispositivos em relação ao parcelamento de débitos tributários, notadamente no que tange aos débitos tributários de devedores em recuperação judicial. Atualmente, existe disposição expressa prevendo que uma lei específica regule as condições do parcelamento de débitos de devedores em recuperação judicial. Na sua falta, aplicam-se os dispositivos das leis gerais de parcelamento do respectivo ente político credor, não podendo este prazo ser inferior ao concedido pela lei federal específica (art. 155-A, $\S 3^{\circ}$ e $\S 4^{\mathrm{o}}$, do CTN $)^{285}$.

Enfim, o parcelamento também não se confunde com a transação. Enquanto aquele é causa suspensiva da exigibilidade do crédito tributário, consistente na possibilidade de pagamento em parcelas, esta é causa extintiva do crédito tributário. Vários são os julgados de nossa Corte Superior no sentido de que o parcelamento não é

\footnotetext{
${ }^{282}$ PAULSEN, Leandro. Direito Tributário - Constituição e Código Tributário à Luz da Doutrina e da Jurisprudência. Porto Alegre: Livraria do Advogado, 2013, p. 1095.

${ }^{283}$ SCHOUERI, Luís Eduardo. Direito Tributário. São Paulo: Saraiva, 2013, p. 608.

${ }^{284}$ COÊLHO, Sacha Calmon Navarro. Curso de Direito Tributário Brasileiro. Rio de Janeiro: Forense, 2012, p. 695.

${ }^{285}$ Sobre a questão do parcelamento de débitos de devedores em recuperação judicial, notadamente em virtude do disposto na Lei Geral de Transação em matéria tributária ( $\left.P L \mathrm{n}^{\circ} 5.082 / 2009\right)$, conferir também item 4.3.2 deste trabalho.
} 
transação e, portanto, não extingue o crédito nem a execução fiscal a ele referente (é o caso, por exemplo, do Resp $n^{\circ} 514.351 / \mathrm{PR}^{286}$ e do Resp $n^{\circ} 1.244 .347 / \mathrm{MS}^{287}$ ).

A remissão, por sua vez, é causa de extinção do crédito tributário. Está prevista no art. 156, IV, do CTN, tendo sido disciplinada no art. 172 deste mesmo Código. Como pontua Paulo de Barros Carvalho, remissão significa perdão, indulgência, indulto ${ }^{288}$. A remissão é, portanto, causa extintiva do crédito, que consiste no perdão do crédito tributário, nele incluindo-se o próprio tributo. Difere-se da anistia, pois que esta somente abrange o perdão das penalidades propriamente ditas ${ }^{289}$, conforme se verá em detalhes mais adiante.

A remissão pressupõe lei autorizadora. Esta autoriza a autoridade administrativa a conceder, por despacho fundamentado, remissão total ou parcial do crédito tributário. Assim como ocorre com a anistia, a isenção, e outros institutos de Direito Tributário, a remissão somente poderá ser concedida por lei específica que regule exclusivamente essa matéria (art. 150, § $6^{\circ}$ da CF/88). Essa lei autorizará a Administração a perdoar (ou não) o crédito tributário de determinado sujeito passivo, a depender de sua situação.

A remissão somente é possível em situações específicas. Tais situações levam em

${ }^{286}$ Resp no 514.351/PR, de relatoria do Min. Luiz Fux - Ementa: "Recurso Especial. Tributário. O parcelamento da dívida tributária nos embargos à execução não implica a extinção da execução mas a sua suspensão. 1. O parcelamento do débito na execução fiscal implica, tão-somente, a suspensão do processo, conservando-se perene a Certidão da Dívida Ativa a sustentar a execução até que se extinga a dívida, podendo operar-se a continuidade da execução fiscal pelo saldo remanescente, se o parcelamento não restar cumprido integralmente pelo sujeito passivo. 2. A figura do parcelamento não se confunde com a transação extintiva do crédito. A autocomposição bilateral ou transação é forma de extinção do crédito tributário, consoante determina o art. 156, III do CTN, implicando no término do direito da Fazenda Pública de cobrar a obrigação tributária. [...]." BRASIL. Superior Tribunal de Justiça. Recurso Especial nº. 514.351/PR, Relator: Ministro Luiz Fux. J. em: 20 nov. 2003. Disponível em : <http://www.stj.jus.br/webstj/Processo/ Justica/detalhe.asp?numreg=200300231637\&pv=010000000000\&tp=51>. Acesso em: 15 mar. 2013.

${ }^{287} \operatorname{Resp~n}^{\circ}$ 1.244.347/MS, de relatoria do Min. Mauro Campbell Marques - Ementa: "Processual Civil. Embargos à execução fiscal. Extinção do processo em virtude de adesão do contribuinte a programa de parcelamento ou pagamento à vista de créditos tributários. Transação não-configurada. Condenação em honorários advocatícios. Cabimento. 1. [...] De acordo com o Código Tributário Nacional, a lei pode facultar, nas condições que estabeleça, aos sujeitos ativo e passivo da obrigação tributária celebrar transação que, mediante concessões mútuas, importe em determinação de litígio e conseqüente extinção de crédito tributário (art. 156, III, c/c art. 171). A lei indicará, ainda, a autoridade competente para autorizar a transação em cada caso (art. 171, parágrafo único). Por não se tratar de transação, não se aplica ao caso o $\S$ $2^{\circ}$ do art. 26 do Código de Processo Civil, segundo o qual, 'havendo transação e nada tendo as partes disposto quanto às despesas, estas serão divididas igualmente' [...]” BRASIL. Superior Tribunal de Justiça. Recurso Especial no. 1.244.347/MS, Relator: Ministro Mauro Campbell Marques. J. em: 14 abr. 2011. Disponível em : <http://www.stj.jus.br/webstj/Processo/Justica/detalhe.asp?numreg=201100503685\&pv= 010000000000\&tp=51>. Acesso em: 13 mar. 2013.

${ }^{288}$ CARVALHO, Paulo de Barros. Curso de Direito Tributário. São Paulo: Saraiva, 2012, p. 541.

${ }^{289}$ MELO, José Eduardo Soares de. Curso de direito tributário. São Paulo: Dialética, 2012, p. 397-398; SCHOUERI, Luís Eduardo. Direito Tributário. São Paulo: Saraiva, 2013, p. 625. 
conta os objetivos de praticabilidade e justiça ${ }^{290}$. São elas: a situação econômica do sujeito passivo, o erro ou ignorância deste quanto à matéria de fato, a diminuta importância do crédito, as condições de equidade e as condições peculiares de determinada região do território do ente tributante (art. 172, I a V, do CTN). Com efeito, somente quando presentes uma das situações acima é que a Administração poderá conceder a remissão.

Enfim, assim como a transação, a remissão é causa de extinção do crédito tributário. Entretanto, dela difere-se, pois que a remissão somente pode ser concedida em situações específicas determinadas pelo CTN. Ademais, a remissão independe de qualquer concessão ou manifestação de vontade por parte do sujeito passivo beneficiário do perdão de sua dívida. Diferentemente, a reciprocidade de concessões é um dos pressupostos da transação em matéria tributária nos termos da redação atual do art. 171 do CTN, conforme se examinará em item próprio nesse trabalho ${ }^{291}$.

A anistia encontra-se entre as causas de exclusão do crédito tributário. Está prevista no art. 175, II, do CTN, tendo sido disciplanda nos arts. 180 e seguintes deste mesmo diploma legal. Parte da doutrina critica o enquadramento da anistia como causa de exclusão do crédito tributário ${ }^{292}$. Argumenta-se que o mais adequado seria colocá-la também como hipótese de extinção do crédito e não exclusão deste como o fez o CTN. Isso porque a anistia faria desaparecer a obrigação tributária, extinguindo o vínculo jurídico existente entre credor e devedor.

Trata-se de instituto de Direito Tributário consistente no perdão das infrações à legislação tributária e das respectivas sanções ${ }^{293}$. Diferencia-se da remissão tributária, examinada anteriormente, justamente porque esta consiste no perdão da totalidade do crédito tributário, enquanto que a anistia é aplicável exclusivamente às penalidades. Em outras palavras a anistia aplica-se sobretudo às multas aplicáveis em razão de determinada infração tributária.

A utilização da anistia encontra restrições no CTN. Primeiro, porque a anistia somente pode abranger infrações cometidas anteriormente à legislação que a concede (art. 180, caput, do CTN); em outras palavras, não é possível conceder anistia com efeitos

\footnotetext{
${ }^{290}$ SCHOUERI, Luís Eduardo. Direito Tributário. São Paulo: Saraiva, 2013, p. 625.

${ }^{291}$ Sobre as concessões recíprocas como pressuposto da transação em matéria tributária, conferir item 3.2.2 deste trabalho.

${ }^{292}$ COÊLHO, Sacha Calmon Navarro. Curso de Direito Tributário Brasileiro. Rio de Janeiro: Forense, 2012, p. 765; SCHOUERI, Luís Eduardo. Direito Tributário. São Paulo: Saraiva, 2013, p. 648 e 663.

${ }^{293}$ PAULSEN, Leandro. Direito Tributário - Constituição e Código Tributário à Luz da Doutrina e da Jurisprudencia. Porto Alegre: Livraria do Advogado, 2013, p. 1221.
} 
prospectivos, isto é, em relação a infrações ainda não praticadas. Segundo, porque a anistia não se aplica aos atos qualificados como crimes ou contravenções ${ }^{294}$, tampouco àqueles atos praticados com dolo, fraude ou simulação (art. 181, I, do CTN). Terceiro, porque a anistia não se aplica às infrações resultantes de conluio entre pessoas naturais ou jurídicas (art. 180, II, do CTN).

Note-se que a anistia pode ser concedida em caráter geral ou limitado, porém sempre por lei. A anistia em caráter geral decorre da própria lei. A anistia em caráter limitado pode se restringir a infrações relativas a determinado tributo, a penalidades de até determinado montante ou de determinada natureza, a uma região específica ou aplicar-se sob condição do pagamento do tributo no prazo fixado pela lei que a conceder (art. 181, II, do CTN). Nessa situação, a anistia é concedida caso a caso, por despacho da autoridade administrativa, que verificará se o interessado preenche as condições e os requisitos estabelecidos em lei para sua concessão (art. 182, caput, do CTN).

Enfim, embora a anistia encontre-se disciplinada como causa de exclusão do crédito tributário, ela é, de fato, uma causa extintiva deste, à semelhança da transação. Entretanto, como reconhece a jurisprudência (é o caso do AgRg nos EDcl no Resp no 1.220.327/MA ${ }^{295}$ ), a anistia não se confunde com a transação. A anistia restringe-se às penalidades por infração e independe de qualquer concessão por parte do sujeito passivo beneficiário do perdão de suas multas. A transação, por sua vez, nos termos da redação do art. 171 do $\mathrm{CTN}$, pressupõe uma série de requisitos, entre os quais, a reciprocidade de concessões. Ademais, a transação não se encontra limitada às penalidades por infração.

Por fim, impende tecer algumas considerações acerca das similitudes e diferenças

\footnotetext{
${ }^{294}$ Para uma análise crítica dessas restrições, conferir SCHOUERI, Luís Eduardo. Direito Tributário. São Paulo: Saraiva, 2013, p. 664.

${ }^{295} \mathrm{AgRg}$ nos EDcl no Resp n ${ }^{\circ}$ 1.220.327/MA, de relatoria do Min. Mauro Campbell Marques - Ementa: "Processual Civil. Agravo Regimental nos Embargos Declaratórios no Recurso Especial. Pagamento dos débitos discutidos judicialmente, após a interposição do Recurso Especial, em virtude de noticiada anisitia fiscal. Inexistência de pedido de desistência ou renúncia ao alegado direito sobre que se funda a ação. Manifestação recebida como aceitação tácita do acórdão proferido pelo Tribunal de origem [...]. 3. Não se aplica ao caso o art. 269, III, do CPC - o qual dispõe que haverá resolução de mérito quando as partes transigirem -, haja vista que a adesão do contribuinte a programa de parcelamento ou pagamento à vista de créditos tributários não configura transação, consoante decidido por esta Turma, no Resp 1.244.347/MS (Rel. Min. Mauro Campbell Marques, DJe de 28.4.2011). Por outro lado, após confirmada pelo Tribunal de origem a sentença de improcedência dos embargos à execução fiscal e depois de interposto o recurso especial, o superveniente pagamento da dívida objeto da execução, mesmo que em virtude de anistia, não enseja a alteração do fundamento legal da extinção do processo do art. 269, I, do CPC, para o art. 267, VI, do mesmo diploma legal. 4. Agravo regimental não provido." BRASIL. Superior Tribunal de Justiça. Agravo Regimental nos Embargos de Declaração no Recurso Especial no. 1.220.327/MA, Relator: Ministro Mauro Campbell Marques. J. em: 16 ago. 2011. Disponível em : < http://www.stj.jus.br/SCON /jurisprudencia/toc.jsp?tipo_visualizacao=null\&processo=1220327\&b=ACOR >. Acesso em: 15 mar. 2013.
} 
entre a transação tributária e o instituto da denúncia espontânea.

A denúncia espontânea encontra-se prevista no art. 138 do CTN, como hipótese de exclusão da responsabilidade tributária por infração e não como causa de suspensão, extinção ou exclusão do crédito tributário em si. Entretanto, forçoso reconhecer que, quando acompanhada do pagamento do tributo e dos juros de mora, a denúncia espontânea extingue o crédito tributário. Decerto, nessa hipótese, o que extingue o crédito tributário é o pagamento, porém a denúncia espontânea tem o condão de afastar a cobrança das penalidades.

Trata-se de instituto que visa a estimular o sujeito passivo a redimir-se de sua infração ${ }^{296}$. Busca o cumprimento espontâneo das obrigações tributárias pelo contribuinte, ainda que este o faça a destempo, desde que isso ocorra, evidentemente, antes do início de qualquer procedimento administrativo ou medida de fiscalização relacionada à infração (art. 138, § único do CTN). Tal estímulo encontra-se em conformidade com a realidade da estrutura da administração tributária, que é incapaz de proceder à fiscalização efetiva de todos os contribuintes ${ }^{297}$.

Tem-se, assim, uma forma de cooperação entre fisco e contribuinte: a Administração fazendária recebe o valor do tributo que the era devido, acrescido dos respectivos juros - que não fora a iniciativa do sujeito passivo da obrigação tributária, talvez jamais tivesse recebido ${ }^{298}$; o contribuinte, por sua vez, regulariza sua situação para com o fisco, beneficiando da exclusão das penalidades a que estaria sujeito em virtude do pagamento a destempo ou, o que é pior, de um eventual procedimento de fiscalização por parte da Administração fazendária.

Um dos pressupostos da denúncia espontânea é que ela ocorra antes do lançamento que constitui o crédito tributário. De fato, em consonância com o CTN, para que efetivamente exclua as penalidades, a denúncia deve ocorrer antes de qualquer procedimento fiscalizatório relacionado à infração ${ }^{299}$. Nos tributos sujeitos a lançamento por homologação, tem-se entendido que a denúncia espontânea não se aplica após a

\footnotetext{
${ }^{296}$ SCHOUERI, Luís Eduardo. Direito Tributário. São Paulo: Saraiva, 2013, p. 781.

${ }^{297}$ PAULSEN, Leandro. Direito Tributário - Constituição e Código Tributário à Luz da Doutrina e da Jurisprudência. Porto Alegre: Livraria do Advogado, 2013, p. 1022.

${ }^{298}$ Ibid., p. 1022.

${ }^{299}$ A esse respeito, importante destacar uma exceção a essa regra: quando iniciado o procedimento de fiscalização, este vier a ser interrompido, hipótese em que se retoma o caráter espontâneo de eventual denúncia apresentada (SCHOUERI, Luís Eduardo. op. cit., p. 782).
} 
apuração e apresentação da declaração pelo contribuinte, posto que o crédito tributário já estaria por este constituído, sendo dispensada, nessa hipótese, a fiscalização ${ }^{300}$.

Ainda em relação à denúncia espontânea, importante destacar que muito se discutiu no passado acerca da possibilidade do contribuinte que optasse por um parcelamento, informando espontaneamente seus débitos tributários. beneficiar-se das reduções de multa previstas para a denúncia espontânea. A jurisprudência do STJ entendeu pela sua impossibilidade, reafirmando o teor da antiga súmula $\mathrm{n}^{\mathrm{o}} 208$ do TFR “ $A$ simples confissão da dívida acompanhda do seu pedido de parcelamento, não configura denúncia espontânea". Considerou que o parcelamento não implica na denúncia espontânea do art. 138 do CTN, na medida em que ele não equivale ao pagamento ${ }^{301}$.

Enfim, a denúncia espontânea diferencia-se da transação tributária, pois que esta é causa extintiva do crédito tributário, ao passo que aquela é instituto tributário que afasta a responsabilidade tributária por infração. Ademais, a denúncia espontânea deve necessariamente ocorrer antes do lançamento (na verdade, antes mesmo de qualquer procedimento fiscalizatório relacionado à infração), enquanto que a transação tributária, nos termos do art. 171 do CTN, somente seria aplicável após o lançamento. Por fím, a transação pressupõe concessões mútuas, havendo a possibilidade, inclusive, de se negociar a forma de pagamento, enquanto que na denúncia espontânea o pagamento do tributo e juros deve se dar de imediato ${ }^{302}$.

\footnotetext{
300 Súmula 360 do STJ: “O benefício da denúncia espontânea não se aplica aos tributos sujeitos a lançamento por homologação regularmente declarados, mas pagos a destempo". BRASIL. Superior Tribunal de Justiça. J. em: 27 ago. 2008. Disponível em : <http://www.stj.jus.br/SCON/sumulas/doc.jsp? livre $=\% 40$ docn $\& \& b=S U M U \& p=$ true $\& \mathrm{t}=\& \mathrm{l}=10 \& \mathrm{i}=140>$. Acesso em: 13 mar. 2013.

${ }^{301}$ Resp n ${ }^{\circ}$ 284.189/SP, de relatoria do Min. Fraciulli Netto - Ementa: "Recurso Especial - alíneas "a" e "c" - Tributário. Parcelamento de débitos de ICMS declarado e não pago - Exclusão da multa moratória Impossibilidade - Alínea "a" - Pretensa violação ao art. 138 do CTN - Inocorrência - Súmula 208 do TFR [...]. O instituto da denúncia espontânea da infração constitui-se num favor legal, uma forma de estímulo ao contribuinte, para que regularize sua situação perante o fisco, procedendo, quando for o caso, ao pagamento do tributo, antes do procedimento administrativo ou medida de fiscalização relacionados com a infração. Nos casos em que há parcelamento do débito tributário, não deve ser aplicado o benefício da denúncia espontânea da infração, visto que o cumprimento da obrigação foi desmembrado, e só será quitada quando satisfeito integralmente o crédito. O parcelamento, pois, não é pagamento, e a este não substitui, mesmo porque não há a presunção de que, pagas algumas parcelas, as demais igualmente serão adimplidas, nos termos do artigo art. 158, I, do mencionado Codex. [...].” BRASIL. Superior Tribunal de Justiça. Recurso Especial no. 284.189/SP, Relator: Ministro Franciulli Netto. J. em: 16 jun. 2002. Disponível em: <http://www.stj.jus.br/SCON/jurisprudencia/toc.jsp?tipo_visualizacao=null\&processo=284189\&b=ACOR $>$. Acesso em: 15 mar. 2013.

${ }^{302}$ A esse respeito, importa destacar que a denúncia espontânea não está imune a críticas. É que, o art. 138 do CTN condiciona a exclusão das penalidades ao efetivo pagamento do tributo e respectivos juros, tendo a jurisprudência afastado a possibilidade de redução da multa quando do parcelamento dos débitos. Tal restrição pode, eventualmente, inviabilizar sua utilização por aqueles que não possuem imediata disponibilidade financeira. Situação diferente parece ocorrer no sistema jurídico alemão. Em conformidade com o disposto nos $\S \S 371$ e 378 do Código Tributário Alemão, a autodenúncia do imposto, com a
} 
Finalmente, note-se que embora esses institutos tenham características próprias, é bastante frequente a confusão entre eles não somente na doutrina como também na jurisprudência pátria. Tal confusão decorre do fato de que, na maioria das vezes, as leis editadas pelos entes políticos misturam os institutos, sendo por vezes difícil ao intérprete identificar qual o regime jurídico aplicável ao caso específico de que tratou a referida lei. É o caso, por exemplo, de algumas leis que instituem planos de parcelamento de débitos tributários. Essa confusão poderá ser, de certa forma, amenizada quando se examinarem os pressupostos da transação, objeto do tópico seguinte.

\subsection{Pressupostos da transação tributária conforme art. 171 do CTN}

Conforme se depreende da análise do art. 171 do CTN, são três os principais pressupostos para a realização da transação em matéria tributária, que serão analisados em detalhes a seguir: uma lei autorizadora (item 3.2.1); a existência de concessões mútuas pelas partes envolvidas (item 3.2.2); e que essas concessões impliquem em (de)terminação do litígio (item 3.2.3).

\subsubsection{Necessidade de lei autorizadora}

Conforme já mencionado, o art. 171, caput, do CTN dispõe que: “A lei pode facultar, nas condições que estabeleça, aos sujeitos ativo e passivo da obrigação tributária celebrar transação que, mediante concessões mútuas, importe em determinação de litígio e consequente extinção do crédito tributário".

Verifica-se, pois, que a transação em matéria tributária depende de autorização legal para sua realização, sendo esta imprescindível sob pena de subversão do sistema. E a razão é simples: se o tributo foi criado por lei, como expressão do consentimento popular, parece lógico que somente outra manifestação desse gênero possa permitir que sejam efetuadas concessões a seu respeito.

Até aí, parece não haver dúvidas: tanto pela lógica do tributo, quanto por disposição expressa do $\mathrm{CTN}$, a lei seria imprescindível para a transação tributária.

complementação ou apresentação de informações, antes omitidas pelo contribuinte, à autoridade fiscal, isenta o agente de sanção na esfera penal (sonegação) e na esfera administrativa (sonegação culposa), desde que haja o pagamento dos impostos sonegados pelo agente. No entanto, esse pagamento não precisa ser de imediato, podendo se dar dentro de prazo razoável assinalado pelo fisco (NOGUEIRA, Ruy Barbosa et al. Novo Código Tributário Alemão. Forense-IBDT: Rio de Janeiro - São Paulo, 1978, p. 143-146). Importante observar que a fixação de "prazo razoável" deverá levar em consideração a situação financeira do contribuinte em questão, inclusive, dependendo do caso, com a possibilidade de remissão do tributo devido. 
A grande questão que surge é saber se a lei a que se refere esse dispositivo é uma lei especifica, que deve conter todos os termos e as condições da transação que se quer realizar em cada caso ou se dita lei poderia também ser uma lei genérica, que apenas autorizaria a autoridade administrativa a celebrar transação estipulando certas condições e limites em que a transação deverá ocorrer, mas deixando certa margem de discricionariedade à Administração na tarefa de transacionar.

Aparentemente, contribui também para essa controvérsia a própria redação do parágrafo único do art. 171 do CTN, que dispõe que: “A lei indicará a autoridade competente para autorizar a transação em cada caso". Isso porque o dispositivo é ambíguo. Não fica claro de sua leitura se é a lei autorizando a transação que deve ser editada em cada caso ou se é a autorização da autoridade competente indicada pela lei que deve ser dada caso a caso.

Talvez querendo compatibilizar as duas situações dentro do sistema brasileiro, Fábio Fanucchi distinguiu duas modalidades de transação tributária possíveis: (a) a transação juris tantum: onde uma lei genérica autorizaria a celebração de transação pela autoridade competente, desde que presentes no caso concreto as circunstâncias legais autorizadoras da transação; e (b) a transação juris et de jure: quando, independentemente de qualquer manifestação da autoridade administrativa, a lei possibilita ao sujeito passivo transacionar permitindo o pagamento de valor inferior àquele originariamente devido ${ }^{303}$.

Várias são as vozes que defendem que a lei a que faz referência o dispositivo do art. 171 do CTN deve, em realidade, ser uma lei específica, não se admitindo autorização genérica nesse sentido. Ao cuidar do assunto, Luís Eduardo Schoueri pontua que o legislador deve, em cada caso, especificar a matéria litigiosa e as condições aplicáveis à transação, não havendo espaço à discricionariedade administrativa ${ }^{304}$. Por sua vez, Eurico Diniz de Santi, citando Paulo de Barros, destaca que somente uma lei específica, voltada a

\footnotetext{
${ }^{303}$ FANUCHI, Fábio. Curso de Direito Tributário Brasileiro. São Paulo: Resenha Tributária, 1975, v.1, p. 340. O autor cita como exemplo de transação juris et de jure o disposto no art. 21, do Decreto-lei 401, de 30 de dezembro de 1968 , que permitia a redução de $50 \%$ da multa aplicada em lançamento ex officio, previsto na legislação do imposto de renda, desde que se recolhesse o débito no prazo legal, sem reclamar ou recorrer do lançamento. Essa segunda modalidade tratada pelo autor parece cuidar não de transação propriamente dita, mas de redução da multa em virtude de dispositivo legal; em outras palavras, parece tratar do instituto da anistia.

${ }^{304}$ SCHOUERI, Luís Eduardo. Direito Tributário. São Paulo: Saraiva, 2013, p. 623. Conforme ilustra o professor da Faculdade de Direito da Universidade de São Paulo: "[...] Muito se tem discutido, recentemente, acerca da possibilidade de o legislador admitir, de forma geral, a transação em matéria tributária. A leitura do dispositivo acima revela sua impossibilidade. [...] A transação em matéria tributária deve ser autorizada por lei. Esta deve especificar qual a matéria litigiosa a qual se aplicará a transação e suas condições".
} 
créditos específicos e determinados poderia autorizar a transação em matéria tributária ${ }^{305}$.

Em sentido contrário, há quem defenda a possibilidade de que a lei autorizadora da transação tributária seja uma lei genérica, aplicável a casos variados ${ }^{306}$. Essa posição fundamenta-se, sobretudo, na inviabilidade de lei específica para cada hipótese de transação. É que, conforme assevera Rubens Miranda de Carvalho, são conhecidas as dificuldades relacionadas ao processo legislativo nos diversos níveis da federação, de forma que a aprovação de uma lei para cada caso de transação, de duas, uma: ou tornaria inviável a transação; ou restringiria sua utilização aos contribuintes que tenham poder para fazer lobby nas respectivas casas legislativas ${ }^{307}$.

A despeito dos posicionamentos de escol em sentido contrário, parece que a lei a que se referiu o legislador ao tratar da transação tributária é genérica. Primeiro, porque realmente exigir uma lei para cada caso concreto de transação significaria dificultar (senão inviabilizar) a transação em matéria tributária, tornando letra morta o disposto no art. 171 do CTN. Segundo, em razão de uma interpretação histórica e teleológica do referido dispositivo: o art. 210 do anteprojeto do CTN elaborado por Rubens Gomes de Sousa previa que a lei tributária poderia autorizar a transação; posteriormente, quando da elaboração do Projeto do CTN, suprimiu-se o adjetivo tributária do dispositivo; a justificativa apresentada para tanto foi de que outras leis, inclusive a lei orgânica do Ministério Público, poderia autorizar a transação ${ }^{308}$. Frise-se que, à época, era o Ministério Público quem defendia a União em matéria tributária e o art. 23, da Lei $n^{\circ}$ 1.341/51, permitia aos órgãos (membros) do Ministério Público transigirem desde que houvesse autorização de seu Procurador Geral. Ora, evidencia-se, pois, que intenção da comissão era permitir que mesmo uma lei genérica, que não especificasse caso a caso as

305 SANTI, Eurico Marcos Diniz de. Transação e arbitragem no Direito Tributário: paranóia ou mistificação? In: FERRAZ, Roberto (Coord). Princípios e limites da tributação 2 - Os princípios da ordem econômica e a tributação. São Paulo: Quartier Latin, 2009, p. 609.

306 TÔRRES, Heleno Taveira. Princípio da segurança jurídica e transação em matéria tributária. Os limites da revisão administrativa dos acordos tributários. In: SARAIVA FILHO, Oswaldo Othon de Pontes; GUIMARÃES, Vasco Branco (Org.). Transação e Arbitragem no Âmbito Tributário. Belo Horizonte: Fórum, 2008, p. 310.

${ }^{307}$ CARVALHO, Rubens Miranda de. Transação Tributária, Arbitragem e outras formas convencionadas de solução de lides tributárias. São Paulo: Juarez de Oliveira, 2008, p. 162.

308 BRASIL. Ministério da Fazenda. Trabalhos da Comissão Especial do Código Tributário Nacional. Rio de Janeiro, 1954, p. 225. Esse dispositivo acabou por acolher: a sugestão $\mathbf{n}^{\mathbf{0}} \mathbf{1 2 6}$, que possuía a seguinte redação: “(A) Idem. (B) Suprimir, no art. 104 alínea IV, a exigência de que a transação seja autorizada por lei tributária. (C) Matéria regulada na lei orgânica do Ministério Público Federal (lei n 1.341, de 30-01-51). A exigência dêste dispositivo, explicitada no art. 210 como referente ao processo administrativo e ao judicial, constitui injustificável quebra de unidade sistemática. (D) Aprovada (67, 112)"; bem como a sugestão n⿳ 175, cuja redação segue: “(A) Idem. (B) No art. 210, suprimir a qualificação 'lei tributária' isso que se refere à transação em juízo (C) Ver a da Sugestão no 126. (D) Aprovada (112).” 
particularidades do conflito e as condições para sua celebração, pudesse autorizar a transação em matéria tributária entre a Fazenda e os contribuintes.

Nesse sentido, a lei (genérica) a que faz referência a legislação tributária poderia facultar a realização da transação pela autoridade administrativa, atribuindo-lhe uma certa margem de discricionariedade. Esse, inclusive, é também é o posicionamento de Onofre Alves Batista Júnior, segundo o qual o art. 171 do CTN, ao dispor que a lei poderá autorizar a realização da transação, permitiu que as pessoas políticas, por meio de lei (genérica), abrisse margens discricionárias à Administração tributária, para que essa pudesse realizar a transação do crédito tributário ${ }^{309}$.

Todavia, em que pese a lei autorizadora poder ser uma lei genérica, ela deve conter alguns parâmetros. Deve estabelecer os limites, os critérios e as circunstâncias em que a transação poderá ser realizada, não sendo aconselhável que se outorgue uma discricionariedade excessiva à Administração ${ }^{310}$. É que, conforme adverte Oswaldo Othon de Pontes Saraiva Filho, se assim o fizer, ter-se-á uma delegação legislativa inconstitucional, na medida em que se estaria infirmando a atribuição precípua do Poder Legislativo de estabelecer tributos ${ }^{311}$.

De qualquer forma, admitindo-se que uma lei genérica possa outorgar poderes para que o administrador celebre transação em matéria tributária, respeitando-se os limites, circunstâncias e as condições nela estabelecidas, é de ver que caberá ao administrador, caso a caso, fundamentar sua decisão de transacionar ${ }^{312}$. Nesse sentido, deverá a autoridade, sempre que optar por concluir uma transação para colocar fim a um litígio entre fisco e contribuinte, justificar os motivos do acordo, permitindo que se possa verificar se a questão se enquadra nas hipóteses e condições autorizadas pela lei.

Em conclusão, em consonância com o teor do disposto no art. 171 do CTN, verifica-se que a lei que faculta a celebração da transação pela Administração tributária, a

\footnotetext{
309 BATISTA JÚNIOR, Onofre Alves. Transação no Direito Tributário, discricionariedade e interesse público. In: Revista Dialética de Direito Tributário. São Paulo: Dialética, n. 83, ago. 2002, p. 122. Em sentido contrário é o posicionamento de Luís Eduardo Schoueri. (SCHOUERI, Luís Eduardo. Direito Tributário. São Paulo: Saraiva, 2013, p. 623).

${ }^{310}$ Acerca dos problemas relativos ao excesso de discricionariedade, conferir item 3.6.2 desse trabalho.

311 SARAIVA FILHO, Oswaldo Othon de Pontes. A transação e a arbitragem no direito constitucionaltributário brasileiro. In: SARAIVA FILHO, Oswaldo Othon de Pontes; GUIMARÃES, Vasco Branco (Orgs.). Transação e Arbitragem no Direito Tributário. Belo Horizonte: Forum, 2008, p. 69. Acerca da compatibilidade da transação em relação ao princípio da legalidade em matéria tributária, conferir item 3.3.1 deste trabalho.

312 CARVALHO, Rubens Miranda de. Transação Tributária, Arbitragem e outras formas convencionadas de solução de lides tributárias. São Paulo: Juarez de Oliveira, 2008, p. 162.
} 
que se refere o supracitado dispositivo, pode sim ser uma lei genérica. Não obstante, a fim de se evitar um excesso de discricionariedade da autoridade administrativa quando da celebração de eventual transação tributária, não poderá tal lei ser demasiadamente genérica. Deverá ela prever de antemão as situações e as condições em que a Administração tributária poderá celebrar a transação. Por fim, caberá à autoridade administrativa motivar, caso a caso, as razões que justificaram a transação.

\subsubsection{Concessões mútuas}

Conforme anteriormente antecipado, a transação pressupõe concessões mútuas das partes. O termo concessão vem do verbo conceder que significa permitir, abrir mão, ceder. Efetuar, uma concessão, para efeitos do disposto no art. 171 do CTN, consiste, pois, em ceder uma parcela de sua pretensão. Em outras palavras, significa abrir mão de uma parte do direito que acredita ter, tendo como objetivo alcançar um meio termo satisfatório para se colocar fim ao litígio existente entre as partes.

Porém não basta que existam concessões. É imprescindível que estas sejam mútuas. Quer dizer, para que haja transação, ambas as partes devem ceder uma parcela de suas pretensões ${ }^{313}$. Deve haver o que se denomina de reciprocidade. É justamente essa reciprocidade de ônus e vantagens que diferencia a transação de outros institutos jurídicos, notadamente a renúncia ao próprio direito ou a submissão ao direito alheio ${ }^{314}$. Nesse sentido, Sacha Calmon pontua que: "se apenas uma parte cede, não há transação, senão que ato unilateral capaz de comover ou demover a outra parte" ${ }^{\text {315. }}$.

Note que o fato de a transação pressupor concessões mútuas não significa que estas concessões devam ter o mesmo valor. Até porque, muitas vezes isso é muito difícil de se aferir. Nesse sentido, parece correta a opinião de Helena Marques Junqueira que, com base nos ensinamentos de Roberto Ruggiero, entende que a reciprocidade não necessariamente implica que as concessões das partes devam ser equivalentes ou

\footnotetext{
313 DINIZ, Maria Helena Diniz. Curso de Direito Civil Brasileiro: teoria das obrigações contratuais e extracontratuais. São Paulo: Saraiva, 2013, v. 3, p. 629 et seq. Nesse sentido, a autora enfatiza que na transação "cada qual abre mão de parte de suas pretensões, fazendo cessar as discórdias".

314 OLIVEIRA, José Jayme de Macedo. Código Tributário Nacional: Comentários, doutrina e jurisprudência. São Paulo: Saraiva, 2010, p. 636-637; JUNQUEIRA, Helena Marques. Transação Tributária. Tese (Doutorado em Direito), Faculdade de Direito da Pontifícia Universidade Católica de São Paulo, 2009, p. 58; JARDIM, Eduardo Marcial Ferreira. Outras formas de extinção do crédito tributário. In: MARTINS, Ives Gandra da Silva (Coord.). Curso de Direito Tributário. São Paulo: Saraiva 1982, p. 166.

${ }^{315}$ COÊLHO, Sacha Calmon Navarro. Curso de Direito Tributário Brasileiro. São Paulo: Forense, 2012, p. 740 et seq.
} 
proporcionais $^{316}$. É que, o conceito de reciprocidade apenas pressupõe a existência de concessões de ambas as partes envolvidas, não se exigindo que a parcela dos direitos que cada parte abra mão seja equivalente à parcela da outra parte.

Para que haja transação em matéria tributária, ambas as partes devem abrir mão de parcela de suas pretensões, sendo esse o significado do termo concessões mútuas, previsto no CTN. Questão que se coloca, no entanto, é saber qual o conteúdo e a abrangência dessas concessões por cada uma das partes envolvidas. Em outras palavras, quais seriam os direitos ou pretensões que seriam cedidos pelas partes; e, em contrapartida de que físco e contribuinte fariam tais concessões?

As concessões efetuadas pelo fisco parecem mais evidentes. Normalmente, consistem na redução dos valores que lhes são devidos pelo contribuinte. Talvez o exemplo mais comum de concessão por parte do fisco seja a redução de multas e juros incidentes em razão do não recolhimento do tributo ou da não entrega de declaração no prazo legal. Porém, podem também ter por objeto os honorários advocatícios ou o encargo legal. Poderá, ainda, consistir na concessão de parcelamento para pagamento dos valores devidos, havendo, inclusive, quem defenda que o fisco possa abrir mão da natureza pecuniária e aceitar o adimplemento de seu crédito por outra prestação ${ }^{317}$. Tudo isso para que haja o imediato recebimento dos valores que lhe são devidos.

As concessões por parte do contribuinte, por sua vez, parecem menos evidentes. Discute-se se realmente existiriam concessões da parte do contribuinte que justificassem a transação tributária pelo fisco ${ }^{318}$. Parece que sim. O simples fato do sujeito passivo abrir

316 JUNQUEIRA, Helena Marques. Transação Tributária. Tese (Doutorado em Direito), Faculdade de Direito da Pontifícia Universidade Católica de São Paulo, 2009, p. 58 et seq.

317 É o caso de Ives Gandra da Silva Martins. Em resumo, o autor sustenta que não haveria óbices à realização de transação por determinado município, em que este recebesse o tributo devido por meio da prestação de serviços com fornecimento de materiais. Quanto mais quando o vencedor do certame licitatório realizado para tanto não teve interesse em realizá-los. (MARTINS, Ives Gandra da Silva. Transação Tributária realizada nos exatos termos do art. 171 do Código Tributário Nacional - Inteligência do dispositivo - Prevalência do interesse público em acordo envolvendo prestação de serviços e fornecimento de material - Rigoroso cumprimento da legislação complementar federal e municipal - Opinião legal. In: SARAIVA FILHO, Oswaldo Othon de Pontes; GUIMARÃES, Vasco Branco (Org.) Transação e arbitragem no âmbito tributário. Belo Horizonte: Fórum, 2008, p. 373-374)

${ }^{318}$ Nesse sentido, vale a pena destacar indagação efetuada por Dolizete Fátima Michelin: "Considerando que a transação pressupõe mútua concessão impõe-se a pergunta: Qual a concessão que o contribuinte fará no modelo de transação proposto? Pagar o tributo com redução da penalidade?" (MICHELIN, Dolizete Fátima. O anteprojeto da Lei Geral de Transação em Matéria Tributária e os princípios constitucionais da legalidade, isonomia e moralidade pública. In: SARAIVA FILHO, Oswaldo Othon de Pontes; GUIMARÃES, Vasco Branco (Orgs.). Transação e Arbitragem no Direito Tributário. Belo Horizonte: Forum, 2008, p. 355). Da mesma forma, é o posicionamento de Eurico Diniz de Santi, como se percebe do trecho a seguir, ao tratar das concessões mútuas: "[...] O anteprojeto de lei é obscuro e lacônico sobre esse relevante ponto para todos os outros contribuintes. Será tão só pagar menos do que era devido e depois?[...]" 
mão da discussão judicial ou administrativa em que questiona a legitimidade do tributo e pagar o valor acordado já é uma forma de concessão. Quanto mais que, normalmente, coloca-se a renúncia ao direito sobre que se funda a controvérsia como requisito ou consequência da própria transação. Demais disso, há quem considere, também, como concessão, por parte do contribuinte, o pagamento de determinado tributo antes de seu vencimento em contrapartida de um desconto em seu valor dado pelo fisco ${ }^{319}$.

Por fim, outra questão bastante polêmica em relação a esse tema é saber até onde podem ir essas concessões recíprocas por parte do fisco. Poderiam elas se dar tanto em relação às multas e juros, como também em relação ao principal propriamente dito? Pois bem, essas e outras questões serão analisadas em mais detalhes quando falarmos sobre a abrangência da transação em matéria tributária mais adiante ${ }^{320}$.

\subsection{3. (De)terminação do Litígio}

Conforme se depreende da legislação em vigor (art. 171, caput, do CTN), faz-se necessário ainda um terceiro pressuposto para a transação em matéria tributária: que esta importe em determinação do litígio e a consequente extinção do crédito tributário.

Parte da doutrina afirma que, ao se referir à determinação do litígio, o legislador quis, em realidade, referir-se sim à terminação do litígio, expressão que faz mais sentido do ponto de vista semântico. Para esses autores, a utilização do termo "determinação" teria sido um erro gráfico na redação do artigo ${ }^{321}$. Esse entendimento é corroborado pela interpretação histórica e contextual desse dispositivo. O art. 136 do Projeto de Código Tributário Nacional, cuja redação deu origem ao atual art. 171 do CTN, utilizava

(SANTI, Eurico Marcos Diniz de. Transação e arbitragem no Direito Tributário: paranóia ou mistificação? In: FERRAZ, Roberto (Coord). Princípios e limites da tributação 2 - Os princípios da ordem econômica e a tributação. São Paulo: Quartier Latin, 2009, p. 605).

${ }^{319}$ Para Eduardo Sabbag, o desconto na multa para pagamento à vista de tributos poderia ser decomposto da seguinte forma: “[...] parcela única do IPVA, IPTU, com desconto (a parte recolhida será extinta pelo pagamento, enquanto a parte descontada será extinta pela transação)”. (SABBAG, Eduardo de Moraes. Manual de Direito Tributário. São Paulo: Saraiva, 2013, p. 889).

${ }^{320}$ Sobre a abrangência da transação tributária em conformidade com o PL n ${ }^{\circ} 5.082 / 2009$, conferir item 4.2.2 deste trabalho.

${ }^{321}$ Esse é o posicionamento, entre outros, de José Jayme de Macedo Oliveira, para quem: “Considerando que o presente artigo refere-se a 'terminação de litígio' (e não 'determinação de litígio', erradamente lá escrito [...]". (OLIVEIRA, José Jayme de Macedo. Código Tributário Nacional: Comentários doutrina e jurisprudência. São Paulo: Saraiva, 2010, p. 636). No mesmo sentido é o entendimento de Helena Marques Junqueira, para quem: "Há um erro de grafia no citado artigo, que coloca a expressão "determinação do litígio", o que é desprovido de lógica e, portanto, sempre se entendeu que se trata, na verdade, de utilização da transação tributária para 'terminação do litígio"'. (JUNQUEIRA, Helena Marques. Transação Tributária. Tese (Doutorado em Direito), Faculdade de Direito da Pontifícia Universidade Católica de São Paulo, 2009, p. 98). 
justamente a expressão "terminação do litígio" ao se referir à transação ${ }^{322}$.

O termo "litígio", empregado na parte final do art. 171 do CTN, por sua vez, significa demanda, contenda, conflito ${ }^{323}$. Em outras palavras, o dispositivo dá conta de que a transação tributária deverá implicar em terminação do conflito de interesses existente entre as partes. À semelhança do que ocorre com a transação no Direito Civil brasileiro, a transação em matéria tributária pressupõe uma dúvida (res dubia) envolvendo uma determinada situação jurídica ${ }^{324}$. Essa dúvida poderá se referir tanto à interpretação da norma jurídica aplicável, quanto à ocorrência ou subsunção dos fatos à norma ${ }^{325}$. E, será justamente essa dúvida que será dirimida pela transação ${ }^{326}$.

Demais disso, figura-se controvertido o próprio significado da expressão "litígio" utilizada no referido dispositivo. Há quem sustente que somente se falaria em litígio quando a controvérsia em questão estivesse retratada em um processo judicial; quer dizer, a transação somente poderia ocorrer quando o conflito estivesse judicializado ${ }^{327}$. Outros, no entanto, admitem que a judicialização da questão controvertida seria prescindível, bastando que a matéria fosse objeto de impugnação administrativa pelo contribuinte; em outras palavras, poderia ocorrer tanto quando a controvérsia já estivesse na fase judicial,

${ }^{322}$ De acordo com o Projeto de Código Tributário Nacional que resultou do anteprojeto de autoria de Rubens Gomes de Sousa: “Art. 136. É facultado aos sujeitos ativo e passivo da obrigação tributária celebrar transação que, mediante concessões mútuas, importe em terminação de litígio e consequente extinção do crédito tributário. Parágrafo único. A lei tributária indicará a autoridade competente para celebrar a transação e as formalidades a serem observadas em cada caso" (grifos acrescentados). BRASIL. Ministério da Fazenda. Trabalhos da Comissão Especial do Código Tributário Nacional. Rio de Janeiro, 1954, p. 59.

${ }^{323}$ MICHAELIS, Moderno Dicionário da Língua Portuguesa. São Paulo: Melhoramentos, 1998.

${ }^{324}$ MACHADO, Hugo de Brito. Transação e arbitragem no âmbito tributário. In: SARAIVA FILHO, Oswaldo Othon de Pontes; GUIMARÃES, Vasco Branco (Orgs.). Transação e Arbitragem no Direito Tributário. Belo Horizonte: Forum, 2008, p. 128; SARAIVA FILHO, Oswaldo Othon de Pontes. A transação e a arbitragem no direito constitucional-tributário brasileiro. In: SARAIVA FILHO, Oswaldo Othon de Pontes; GUIMARÃES, Vasco Branco (Orgs.). Transação e Arbitragem no Direito Tributário. Belo Horizonte: Forum, 2008, p. 62; JARDIM, Eduardo Marcial Ferreira. Outras formas de extinção da obrigação tributária. In: MARTINS, Ives Gandra da Silva. Curso de Direito Tributário. São Paulo: Saraiva, 1982, p. 166.

325 JUNQUEIRA, Helena Marques. Transação Tributária. Tese (Doutorado em Direito), Faculdade de Direito da Pontifícia Universidade Católica de São Paulo, 2009, p. 193.

${ }^{326}$ MARTINS FILHO, Luiz Dias; ADAMS, Luís Inácio Lucena. A transação no Código Tributário nacional (CTN) e as novas propostas normativas de leis autorizadoras. In: SARAIVA FILHO, Oswaldo Othon de Pontes; GUIMARÃES, Vasco Branco (Orgs.). Transação e Arbitragem no Direito Tributário. Belo Horizonte: Forum, 2008, p. 39.

${ }^{327}$ Esse é o posicionamento de Bernardo Ribeiro de Moraes, para quem "como litígio somente existe em processo contencioso, onde existe formação de juízo para a apreciação da causa, a transação somente pode ser realizada em processos judiciais". (MORAES, Bernardo Ribeiro de. Compêndio de Direito Tributário. [S.1.]: Forense, 1984, p. 457 et seq). Também nesse mesmo sentido é o entendimento de José Jayme de Macedo Oliveira "[...] só se pode cogitar de transação em havendo processo contencioso de natureza judicial". (OLIVEIRA, José Jayme de Macedo. Código Tributário Nacional: Comentários doutrina e jurisprudência. São Paulo: Saraiva, 2010, p. 636) 
quanto quando ainda estivesse na fase administrativa ${ }^{328}$.

Esse último entendimento parece ser o mais razoável. É que, considerando que a transação em matéria tributária tem por finalidade resolver uma relação jurídica conflituosa entre fisco e contribuinte, não há porque limitar sua aplicação somente às controvérsias judicializadas, sob pena de se reduzir despropositadamente a eficácia desse instituto. Além disso, não parece existir razão plausível para afastar da transação as discussões administrativas, até porque essas representam enorme volume e tem um alto custo para a Administração tributária e o contribuinte.

Ademais, importa ressaltar que a quase unanimidade dos doutrinadores sustentam que, contrariamente ao que ocorre em Direito Civil, onde a transação pode ser preventiva ou terminativa ${ }^{329}$, em matéria tributária somente se admitiria a transação terminativa. Isso porque, a redação do art. 171, caput, do CTN expressamente prevê que seria facultado às partes celebrar transação que importe em (de)terminação do litígio ${ }^{330}$. Segundo esse posicionamento, não havendo qualquer menção no referido dispositivo acerca da possibilidade de prevenção do litígio pela transação, ter-se-ia, implicitamente, vedado a transação preventiva.

Helena Marques Junqueira, entretanto, pondera que não existiria nenhuma vedação a que o instituto da transação tributária tivesse a mesma abrangência que ele tem

${ }^{328}$ CARVALHO, Paulo de Barros. Curso de Direito Tributário. São Paulo: Saraiva, 2012, p. 540-541; DACOMO, Natalia de Nardi. Direito Tributário participativo: transação e arbitragem administrativas da obrigação tributária. Tese (Doutorado em Direito), Faculdade de Direito da Pontifícia Universidade Católica de São Paulo, 2008, p. 118-119; MACHADO, Hugo de Brito. Transação e arbitragem no âmbito tributário. In: SARAIVA FILHO, Oswaldo Othon de Pontes; GUIMARÃES, Vasco Branco (Orgs.). Transação e Arbitragem no Direito Tributário. Belo Horizonte: Forum, 2008, p. 116-117; JUNQUEIRA, Helena Marques. Transação Tributária. Tese (Doutorado em Direito), Faculdade de Direito da Pontifícia Universidade Católica de São Paulo, 2009, p. 98-99.

${ }^{329} \mathrm{Cf}$. item 3.1.1 deste trabalho.

${ }^{330}$ Nesse sentido, conferir Hugo de Brito Machado: "E não pode haver transação para prevenir litígio. Só depois de instaurado este, é possível a transação." E a razão é simples, continua o professor cearense: “[...] não sendo a transação forma comum de extinção do crédito tributário, nada justifica sua permissão a não ser nos casos em que efetivamente exista um litígio". (MACHADO, Hugo de Brito. Curso de Direito Tributário. São Paulo: Malheiros, 2012, p. 222). Também Oswaldo Othon de Pontes Saraiva Filho, compartilha da mesma posição: "Diante de tal preceptivo legal, se pode deduzir que, atualmente, só pode haver uma autêntica transação para extinguir litígio [...]". E mais adiante assevera, ainda, que: "Diante da inocorrência, ainda, de uma pretensão resistida, ou de inexistência de uma relação jurídica duvidosa, posta em processo administrativo ou judicial, a transação não tem objeto ou finalidade, parecendo um absurdo se cogitar de uma transação preventiva, para prevenir litígio, quando, por exemplo, sequer ocorreu o fato gerador [...]”. (SARAIVA FILHO, Oswaldo Othon de Pontes. A transação e a arbitragem no direito constitucional-tributário brasileiro. In: SARAIVA FILHO, Oswaldo Othon de Pontes; GUIMARÃES, Vasco Branco (Orgs.). Transação e Arbitragem no Direito Tributário. Belo Horizonte: Forum, 2008, p. 69). Ainda, no mesmo sentido de que transação em matéria tributária somente pode ser terminativa, não se admitindo a transação na modalidade preventiva, conferir COÊLHO, Sacha Calmon Navarro. Curso de Direito Tributário brasileiro. Rio de Janeiro: Forense, 2012, p. 740. 
no Direito Civil, desde que, obviamente, observadas as peculiaridades da relação jurídicotributária. Preconiza, assim, que a transação tributária poderia ser utilizada também para prevenir litígios. Baseia-se no fato de que a relação jurídica entre fisco e contribuinte é conflituosa por natureza: os conflitos não surgiriam somente a partir do lançamento, podendo existir já desde a publicação da norma jurídica tributária, que cria ou modifica a hipótese de incidência de um tributo ou algum de seus elementos ${ }^{331}$.

De fato, na forma em que se encontra redigido o art. 171, caput, do CTN, tem-se que a transação tributária a que se referiu o dispositivo teria tão somente o condão de colocar fim aos litígios já existentes. E a razão parece lógica: o CTN não incluiu a transação preventiva em tal dispositivo, pois que tratou desse instituto como modalidade de extinção do crédito tributário, em que se pressupõe a existência de lançamento já constituído. Entretanto, isso não impede que se previnam litígios entre físco e contribuintes por meio de algum outro instrumento jurídico - é o caso da consulta, do acordo prévio em matéria de preços de transferência, da denúncia espontânea e outros ${ }^{332}$. Tais instrumentos são importantes para garantir segurança jurídica e evitar eventuais futuros conflitos, inclusive, antes mesmo do lançamento do crédito tributário.

Em conclusão, um dos pressupostos da transação é que ela importe em terminação do litígio (conflito de interesses). A transação poderia se aplicar tanto aos conflitos na fase judicial, como àqueles ainda na fase administrativa. Apesar de existir posicionamento em sentido contrário, inclusive com argumentação que parece bastante coerente, a doutrina majoritária sustenta que, por conta da redação do art. 171, caput, do CTN, a transação tributária teria uma amplitude menor que a transação civil, não havendo que se falar em transação tributária preventiva, mas somente terminativa. Isso não impede, entretanto, que outros instrumentos jurídicos sejam utilizados para prevenir conflitos entre físco e contribuintes.

\subsection{Os possíveis conflitos com o ordenamento jurídico brasileiro}

Conforme visto até aqui, apesar da transação ter origem no Direito Civil, ela possui reflexos também no Direito Tributário, onde se encontra dotada de algumas características próprias desse ramo do direito. Ademais, analisou-se, também, que a

\footnotetext{
331 JUNQUEIRA, Helena Marques. Transação Tributária. Tese (Doutorado em Direito), Faculdade de Direito da Pontifícia Universidade Católica de São Paulo, 2009, p. 98 et seq.

${ }^{332}$ Acerca de alguns desses mecanismos de negociação entre fisco e contribuinte, conferir item 1.3. deste trabalho.
} 
transação tributária encontra-se expressamente prevista no CTN, entre as modalidades de extinção do crédito tributário, já se tendo, inclusive, examinado alguns de seus pressupostos no item anterior.

Não obstante esses fatos, que dão conta da possibilidade do instituto da transação em matéria tributária, diversos são os autores que colocam obstáculos a sua utilização em nosso ordenamento jurídico. Alguns desses argumentos são de que a transação tributária seria incompatível com: o princípio da legalidade tributária (item 3.3.1); a obrigatoriedade do lançamento e da cobrança do crédito tributário (item 3.3.2); o art. 14 da Lei de Responsabilidade Fiscal (item 3.3.3); e d) a igualdade tributária (item 3.3.4).

\subsubsection{Legalidade tributária (arts. $5^{\circ}$, II e 150, I da CF/88)}

Uma das principais dificuldades (senão a principal dificuldade) apontada pela doutrina para a aceitação da transação em matéria tributária consiste no princípio da legalidade tributária ${ }^{333}$. É que, em conformidade com esse princípio, que serve de fundamento para legitimar a tributação pelo Estado, as regras fiscais aplicáveis em determinado ordenamento deveriam ser fixadas pela lei, não cabendo à Administração tributária qualquer margem de discricionariedade no que diz respeito à criação ou modificação de tributos (ou seus elementos), bem como à extinção destes.

Conforme visto anteriormente, apesar de existirem outros antecedentes históricos ${ }^{334}$, entende-se que o princípio da legalidade surgiu com o advento da "Magna Charta Libertatum" assinada por João Sem Terra, da Inglaterra, em 1215 ${ }^{335}$. Esse documento retratou o anseio da sociedade em limitar os poderes do Estado, notadamente em relação à cobrança de tributos pelo soberano. Ademais, é ele considerado a origem do princípio da autotributação ou princípio do consentimento ${ }^{336}$.

A partir de então, observou-se uma evolução desse princípio, ao longo dos séculos, de maneira diferente em conformidade com as circunstâncias locais.

\footnotetext{
333 MICHELIN, Dolizete Fátima. O anteprojeto da Lei Geral de Transação em Matéria Tributária e os princípios constitucionais da legalidade, isonomia e moralidade pública. In: SARAIVA FILHO, Oswaldo Othon de Pontes; GUIMARÃES, Vasco Branco (Orgs.). Transação e Arbitragem no Direito Tributário. Belo Horizonte: Forum, 2008, p. 333; SARAIVA FILHO, Oswaldo Othon de Pontes. A transação e a arbitragem no direito constitucional-tributário brasileiro. In: SARAIVA FILHO, Oswaldo Othon de Pontes; GUIMARÃES, Vasco Branco (Orgs.). Transação e Arbitragem no Direito Tributário. Belo Horizonte: Forum, 2008, p. 51-52; 66-68.

${ }^{334}$ SCHOUERI, Luís Eduardo. Direito Tributário. São Paulo: Saraiva, 2013, p. 280-283.

${ }^{335} \mathrm{Cf}$. item 1.1.1 deste trabalho.

${ }^{336}$ Acerca da evolução do princípio do consentimento, conferir itens 1.1.1 e 1.2.1 deste trabalho.
} 
Desenvolveu-se de forma diversa na Inglaterra e nos demais países europeus. Enquanto na Inglaterra a legalidade afirmou-se progressivamente, estando relacionado à transformação do conselho de comuns em autêntico órgão de representação popular (Parlamento), seguida por outros marcos fundamentais, nos demais países europeus, essa afirmação se deu de forma revolucionária: a partir da Revolução Francesa ${ }^{337}$.

Demais disso, verifica-se também que o princípio da legalidade passou a servir de fundamento para outros ramos do Direito. Nascido com caráter nitidamente tributário, para limitar o poder estatal e evitar abusos na cobrança de tributos, posteriormente, o princípio da legalidade ampliou seu raio de atuação para as demais atividades estatais (não tributárias), submetendo toda e qualquer atividade estatal aos ditames da lei. Nesse contexto, Gerd Willi Rothmann destaca que o princípio da legalidade surge, a partir do século XIX, também como princípio geral do Direito Administrativo ${ }^{338}$.

Observam-se, ainda, outras alterações em relação ao princípio da legalidade em matéria tributária no decorrer dos anos. De um lado, tem-se que a transformação do mandato imperativo em mandato livre permitiu que os representantes dos contribuintes passassem a tomar suas deliberações livremente, não mais estando vinculados a diretrizes que estabeleciam as matérias e o sentido em que deveriam votar. De outro lado, o princípio da legalidade, que era visto sob o aspecto somente formal (necessidade de lei, aprovada como tal pelos representantes do povo, para criar ou modificar um determinado tributo), passa a ser visto também sob o aspecto material (não basta que a lei crie ou modifique um tributo, devendo também disciplinar seus elementos essenciais ${ }^{339}$.

No Brasil, atualmente, o princípio da legalidade encontra-se previsto no texto constitucional com uma faceta dúplice, que adveio das mudanças ocorridas com o passar dos anos: (a) não tributária, como direito e garantia individual dos cidadãos, prevista no art. $5^{\circ}$, II, da CF/88, que dispõe que "ninguém será obrigado a fazer ou deixar de fazer alguma coisa senão em virtude de lei"; e (b) tributária, como limitação ao poder de

\footnotetext{
337 NABAIS, José Casalta. Contratos Fiscais: reflexões acerca da sua admissibilidade. Coimbra: Coimbra, 1994, p. 216-217. Nesse sentido, conferir também Gerd Willi Rothmann. Segundo o autor, o mesmo teria se dado nos Estados Unidos, com o movimento que culminou em sua independência. O professor da Universidade de São Paulo destaca ainda que esses movimentos foram resultado da atividade arbitrária do Estado e tiveram por consequência erigir a limitação ao poder de tributar a status de princípio constitucional. (ROTHMANN, Gerd Willi. O princípio da legalidade tributária. In: NOGUEIRA, Ruy Barbosa. Direito Tributário: Estudos de casos e Problemas. São Paulo: José Bushatsky, 1973, p. 147-148).

${ }^{338}$ Ibid., p. 151-152. Sobre a compatibilidade do instituto da transação com o princípio da legalidade administrativa, conferir item 2.2.1. deste trabalho.

${ }^{339}$ NABAIS, José Casalta. op. cit., p. 218-220.
} 
tributar, prevista no art. 150, I da CF/88, que dispõe ser "vedado à União, aos Estados, ao Distrito Federal e aos Municípios: exigir ou aumentar tributo sem lei que o estabeleça".

Poder-se-ia eventualmente questionar a necessidade e as implicações dessa dupla previsão constitucional da legalidade. Todavia, como destaca Luís Eduardo Schoueri, ao comparar os respectivos dispositivos, verifica-se que o constituinte não foi redundante. De um lado, a legalidade administrativa pressupõe que um comportamento somente será exigido em razão de uma lei (art. $5^{\circ}$, II, da CF/88). De outro, a legalidade tributária exige que a obrigação tributária esteja prevista na própria lei (art. 150 , I da $\mathrm{CF} / 88)^{340}$. A exigência da obrigação tributária estar delineada em lei está contemplada também no art. 97 do CTN. De acordo com esse dispositivo, a lei deverá definir o fato gerador dos tributos (e seus respectivos elementos essenciais) ${ }^{341}$. Verifica-se, pois, que o princípio da legalidade tributária no ordenamento brasileiro possui ambos os aspectos: formal e material.

Analisando o princípio da legalidade no ordenamento pátrio sob a égide da Constituição anterior - porém com aplicação ainda nos dias de hoje -, Gerd Willi Rothmann destaca diferentes feições desse princípio: (a) legalidade da Administração: essa regra significa o dever da Administração agir com base nos ditames não somente da lei, mas sim do direito como um todo, nele incluindo-se também as diversas normas administrativas; (b) reserva da lei: essa regra seria uma especificação da anterior, porém, vincularia a Administração não ao direito de forma genérica, mas à lei em seu aspecto formal; quer dizer, à lei elaborada e aprovada com participação popular; (c) estrita legalidade tributária: regra que impede que sejam instituídos ou majorados tributos sem lei que o estabeleça e que encontraria respaldo no atual art. 150, I da CF/88; e (d) conformidade da tributação com o fato gerador: regra que determina que o legislador deve descrever pormenorizadamente todos os aspectos do fato gerador, necessários ao

\footnotetext{
${ }^{340}$ SCHOUERI, Luís Eduardo. Direito Tributário. São Paulo: Saraiva, 2013, p. 288 et seq.

${ }^{341}$ Art. 97. Somente a lei pode estabelecer:

I - a instituição de tributos, ou a sua extinção;

II - a majoração de tributos, ou sua redução [...];

III - a definição do fato gerador da obrigação tributária principal [...];

IV - a fixação da alíquota do tributo e da sua base de cálculo [...];

$\mathrm{V}$ - a cominçaão de penalidades para ações ou omissões contrárias a seus dispositivos, ou para outras infrações nela definidas;

VI - as hipóteses de exclusão, suspensão e extinção de créditos tributários, ou de dispensa ou redução de penalidades.

$\S 1^{\circ}$ Equipara-se à majoração do tributo a modificação de sua base de cálculo, que importe em torná-lo mais oneroso.

$\S 2^{\circ}$ Não constitui majoração de tributo, para os fins do disposto no inciso II deste artigo, a atualização do valor monetário da respectiva base de cálculo. (grifos acrescentados)
} 
surgimento da obrigação tributária, notadamente os seguintes: aspecto objetivo ou material, aspecto subjetivo, aspecto espacial, aspecto temporal e aspecto quantitativo ${ }^{342}$.

Entretanto, assim como aconteceu no decorrer dos séculos desde o seu surgimento, o princípio da legalidade vem sofrendo algumas transformações também nos últimos anos. Isso se dá em decorrência das profundas alterações por que passou a concepção de Estado no século passado: da passagem de um Estado Liberal para um Estado Social e Democrático (ou, mais recentemente, como destaca Ricardo Lobo Torres, com a sua reconfiguração em Estado Cooperativo $)^{343}$. Essa transformação, conjugada ao incremento de alguns outros objetivos da tributação na atualidade ${ }^{344}$, impactaram consideravelmente o princípio da legalidade nos últimos tempos, a tal ponto que José Casalta Nabais, já há alguns anos, falava em "crise do princípio da legalidade fiscal"345.

Parece que o termo crise seja um tanto excessivo, preferindo-se utilizar a expressão mitigação ou temperamento do princípio da legalidade para retratar o status atual desse princípio, tão importante em matéria de tributação. De fato, a fiscalidade contemporânea apresenta algumas particularidades que exigem uma maior flexibilização da noção tradicional de legalidade tributária. É que, dado o alto grau de complexidade e tecnicismo das relações jurídicas tributárias na atualidade, verifica-se praticamente impossível para o legislador descrever, com precisão, todos os aspectos do fato gerador ${ }^{346}$.

${ }^{342}$ ROTHMANN, Gerd Willi. O princípio da legalidade tributária. In: NOGUEIRA, Ruy Barbosa. Direito Tributário: Estudos de casos e Problemas. São Paulo: José Bushatsky, 1973, p. 151 et seq.

343 TORRES, Ricardo Lobo. Transação, conciliação e processo tributário administrativo equitativo. In: SARAIVA FILHO, Oswaldo Othon de Pontes; GUIMARÃES, Vasco Branco (Orgs.). Transação e Arbitragem no Direito Tributário. Belo Horizonte: Forum, 2008, p. 95.

${ }^{344}$ Acerca dos vários objetivos da tributação e sua evolução em conformidade com o desenvolvimento e a forma de concepção do Estado, conferir item 1.1.2.

345 NABAIS, José Casalta. Contratos Fiscais: reflexões acerca da sua admissibilidade. Coimbra: Coimbra, 1994, p. 230-231. De acordo com o professor da Faculdade de Coimbra, essa crise poderia assumir várias formas, destacando-se: (a) o surgimento de diversas figuras próximas ao imposto, porém com tratamento tributário distinto, inclusive no que tange à legalidade: é o caso, por exemplo, das taxas e impostos parafiscais, que se destinam a organismos públicos ou privados para serem aplicadas nas suas finalidades; (b) o advento da fiscalidade inter ou supranacional, que em nível europeu pode ser percebido com a União Européia e a pauta aduaneira comum, que limitam o alcance do consentimento parlamentar; e (c) o poder fiscal da Administração, que compreende a utilização de uma técnica legislativa especial na elaboração da legislação, outorgando uma maior flexibilidade para que a Administração possa manejar os tributos extrafiscais e a execução tipificada da lei. (NABAIS, José Casalta. Contratos Fiscais: reflexões acerca da sua admissibilidade. Coimbra: Coimbra, 1994, p. 230 et seq). Sobre a questão da limitação da autonomia dos países membros da União Européia, note-se que, nos dias de hoje, essa idéia pode ser reforçada em decorrência da evolução desse órgão supranacional nas últimas decádas, com imposição de uma série de limitações não somente no âmbito da tributação indireta de seus Estados membros, como também da sua tributação direta. A esse respeito, inclusive, já tive oportunidade de me manifestar no artigo: Regime dos Auxílios Estatais em Matéria Tributária no Âmbito da União Europeia e sua Interpretação pela Comissão Europeia e pela CJUE: seria o Fim da Autonomia dos Estados membros em Matéria de Política Fiscal. In: Direito Tributário Atual, v. 27, p. 356, 2012.

346 LOPEZ, Maria Esther Sánchez. El acuerdo de voluntades en el âmbito tributário. In: SARAIVA 
Diante desse quadro, admite-se que o legislador tributário utilize-se de técnica legislativa, consistente no emprego de cláusulas gerais e conceitos jurídicos indetermi$\operatorname{nados}^{347}$. Esses, por serem dotados de vagueza e indeterminação, permitem uma maior maleabilidade e conformação da norma jurídica às situações concretas. Tal técnica não é somente admitida em Direito Tributário como também desejável do ponto de vista prático (princípio da praticabilidade), na medida em que permite que sejam abarcadas pela norma tributária outras situações que venham a surgir, sem que haja necessidade de se alterar a legislação a todo momento ${ }^{348}$. Porém, é dessa técnica que provém muitas vezes a dúvida (res dubia), que dá ensejo ao litígio entre físco e contribuinte ${ }^{349}$.

A título exemplificativo, o emprego de cláusulas gerais e conceitos jurídicos indeterminados faz com que a noção de preço justo ou preço de mercado, para fins de aplicação das regras de preço de transferência, seja ajustada às circunstâncias do caso concreto $^{350}$. O mesmo ocorre com a noção de valor venal para fins de incidência do Imposto sobre Propriedade Territorial Urbana (IPTU). E, ainda, com a definição de despesas operacionais, para fins de apuração do lucro real, bem como com o conceito de mora contumaz, previsto em alguns dispositivos legais, para se negar eventual benefício fiscal concedido pela legislação ${ }^{351}$.

De fato, a utilização desses instrumentos na redação da norma jurídica tributária não deve ser considerada como contrária ao princípio da legalidade em seu sentido tradicional. Trata-se, em realidade, de uma decorrência da complexidade das relações jurídicas tributárias na atualidade, que exige uma mitigação ou um temperamento de seu conteúdo e abrangência nos dias atuais. Com isso, permite-se que a norma seja adaptada às circunstâncias do caso concreto, bem como abarque as mais diversas situações jurídicas que podem vir a surgir em decorrência da evolução dos fenômenos econômicos.

FILHO, Oswaldo Othon de Pontes; GUIMARÃES, Vasco Branco (Orgs.). Transação e Arbitragem no Direito Tributário. Belo Horizonte: Forum, 2008, p. 195 et seq.

347 NABAIS, José Casalta. Contratos Fiscais: reflexões acerca da sua admissibilidade. Coimbra: Coimbra, 1994, p. 233.

348 SCHOUERI, Luís Eduardo. Direito Tributário. São Paulo: Saraiva, 2013, p. 299 et seq.

349 Sobre o conceito de dúvida e a abrangência de litígio, conferir item 3.2.3 deste trabalho.

350 TORRES, Ricardo Lobo. Transação, conciliação e processo tributário administrativo equitativo. In: SARAIVA FILHO, Oswaldo Othon de Pontes; GUIMARÃES, Vasco Branco (Orgs.). Transação e Arbitragem no Direito Tributário. Belo Horizonte: Forum, 2008, p. 92 e 109. A esse respeito, importa destacar que o professor da UERJ diferencia duas situações onde seria possível a análise casuística pela Administração tributária: (a) tipificação: complementação normativa por meio de regulamento ou no próprio processo administrativo tributário; e (b) quantificação: definição de limites para a base de cálculo dos impostos, onde se inseriria não somente a questão do "preço justo" acima examinado, como também da substituição tributária.

351 SCHOUERI, Luís Eduardo. op. cit., p. 302 et seq. 
A doutrina não é uníssona, todavia, em relação às consequências do emprego de conceitos jurídicos indeterminados e cláusulas gerais, notadamente no que diz respeito à possibilidade de existir discricionariedade do fisco em decorrência de tal circunstância. De um lado, há aqueles que acreditam que o emprego desses instrumentos normativos não significa, de modo algum, a aceitação de que o fisco goze de discricionariedade em matéria tributária ${ }^{352}$. De outro, por sua vez, há aqueles que consideram que a utilização desses instrumentos para a descrição dos diversos aspectos do fato gerador permite uma margem ampla de atuação por parte do fisco ${ }^{353}$. Para essa corrente, seria justamente a discricionariedade que justificaria a ponderação dos interesses em jogo, bem como a efetiva participação do contribuinte no que se denomina "processo equitativo fiscal", com seus diversos corolários, entre os quais, a transação em matéria tributária ${ }^{354}$.

Em conclusão, viu-se até aqui que o princípio da legalidade tributária torna indispensável a existência de lei para a instituição ou majoração de tributos. Analisouse, também, que o conceito de legalidade evoluiu ao longo dos anos deixando de ter um aspecto meramente tributário e passando também a ter um aspecto administrativo, pressuposto de toda e qualquer atividade estatal. Demais disso, verificou-se que, na atualidade, esse princípio vem sendo atenuado, admitindo-se a utilização de conceitos jurídicos indeterminados e cláusulas gerais para definir os aspectos do fato gerador. Finalmente, verificou-se que esses instrumentos permitem uma maior maleabilidade da norma jurídica, permitindo sua melhor adaptação às circunstâncias do caso concreto e um certo grau de discricionariedade administrativa. Essa, por sua vez, justifica a maior participação do contribuinte no processo fiscal, inclusive, por meio da transação tributária.

A pergunta que remanesce, no entanto, é saber se esse princípio impacta a extinção dos tributos, mais precisamente, a extinção destes pela transação tributária.

Pois bem, o princípio da legalidade em matéria tributária vai além da exigência de lei para instituição ou majoração de tributos (e fixação de seus elementos essenciais).

\footnotetext{
${ }^{352}$ É o caso, a titulo exemplificativo, de Luís Eduardo Schoueri. (Direito Tributário. São Paulo: Saraiva, 2013, p. 305 et seq).

${ }^{353}$ É o caso de Maria Esther Sánchez Lopes e Ricardo Lobo Torres. (LOPEZ, Maria Esther Sánchez. El acuerdo de voluntades en el âmbito tributário. In: SARAIVA FILHO, Oswaldo Othon de Pontes; GUIMARÃES, Vasco Branco (Orgs.). Transação e Arbitragem no Direito Tributário. Belo Horizonte: Forum, 2008, p. 195-196); (TORRES, Ricardo Lobo. Transação, conciliação e processo tributário administrativo equitativo. In: SARAIVA FILHO, Oswaldo Othon de Pontes; GUIMARÃES, Vasco Branco (Orgs.). Transação e Arbitragem no Direito Tributário. Belo Horizonte: Forum, 2008, p. 107).

354 TORRES, Ricardo Lobo. op. cit., p. 93-94 e 102. Para maiores esclarecimentos em relação à colaboração e o estreitamento das relações entre fisco e contribuinte, como reflexo das preocupações contemporâneas do Direito Tributário, conferir item 1.2.3 deste trabalho.
} 
Exige também que, uma vez instituído ou majorado o tributo, somente a lei possa dispensar o contribuinte de seu recolhimento ${ }^{355}$. Tal raciocínio encontra respaldo no art. 97, VI, do CTN, que prevê que "somente a lei pode estabelecer as hipóteses de exclusão, suspensão e extinção de créditos tributários, ou de dispensa ou redução de penalidades".

Ocorre que o próprio CTN, que nada mais é do que uma lei - recepcionada com força de lei complementar, conforme já analisado -, previu expressamente, em seu art. 156, III, a transação como modalidade de extinção do crédito tributário. Essa, por sua vez, foi regulamentada no art. 171, caput, que previu a necessidade de uma outra lei autorizando a transação ${ }^{356}$. Não há que se falar, portanto, em incompatibilidade da transação tributária com o princípio da legalidade, que exige lei para instituir ou majorar o tributo, como também para dispensar o seu recolhimento. É que, nesse último caso, é a própria lei que a autoriza a dispensa (total ou parcial) do recolhimento pela transação.

Por fim, importa salientar que a transação tributária como forma de solução de litígio encontra respaldo não somente no princípio da legalidade tributária como também constitui-se em uma forma mais adequada de se realizar o interesse público ${ }^{357}$. Tem-se assim, como bem destaca Luís Eduardo Schoueri, uma conciliação entre o princípio da legalidade, que autoriza a transação, e o princípio do interesse público, que muitas vezes será melhor realizado se reduzidos os litígios judiciais ${ }^{358}$.

\subsubsection{Obrigatoriedade do lançamento e da cobrança do crédito tributário (arts. $3^{\circ}$ e 142, § único, do CTN)}

Outra grande dificuldade apontada pela doutrina para a aceitação da transação em matéria tributária consiste na obrigatoriedade do fisco lançar e cobrar o crédito tributário. Essa obrigatoriedade teria como fundamento o princípio da indisponibilidade do interesse público e as disposições do art. $3^{\circ}$ e 142 , § único, do CTN.

Costuma-se dizer que a celebração de acordos pela Administração Pública viola o princípio da indisponibilidade do interesse público ${ }^{359}$, especialmente quando se trata de uma controvérsia em matéria tributária. Essa afirmação tem por base o fato de que um

\footnotetext{
${ }^{355}$ SCHOUERI, Luís Eduardo. Direito Tributário. São Paulo: Saraiva, 2013, p. 294.

${ }^{356}$ Acerca da necessidade desta lei ser específica ou da possibilidade de ser genérica, conferir item 3.2.1 supra.

${ }^{357}$ LOPEZ, Maria Esther Sánchez. El acuerdo de voluntades en el âmbito tributário. In: SARAIVA FILHO, Oswaldo Othon de Pontes; GUIMARÃES, Vasco Branco (Orgs.). Transação e Arbitragem no Direito Tributário. Belo Horizonte: Forum, 2008, p. 208-209.

${ }^{358}$ SCHOUERI, Luís Eduardo. op. cit., p. 622-623.
} 
acordo desse gênero implicaria em inaceitável renúncia de receitas tributárias por parte do ente tributante. Porém, a indisponibilidade do interesse público não impede per se a transação em matéria tributária.

É que, apesar da transação poder vir a reduzir o valor devido pelo contribuinte, afetando o interesse arrecadatório do fisco, a coletividade, de um modo geral, poderá estar sendo beneficiada. A redução da litigiosidade e a desobstrução do Poder Judiciário interessam à toda a sociedade. Além do mais, o interesse público pressupõe ponderação quando de sua aplicação em um caso concreto. Com efeito, deve-se avaliar o custobenefício dos valores em jogo (no caso, o interesse público na arrecadação tributária perante a eficiência e a segurança jurídica).

Nesse contexto é que entra a diferenciação entre interesse público primário e interesse público secundário, já examinada no Capítulo II. O crédito tributário (interesse público secundário) será um direito disponível quando a sua renúncia resultar na prevalência do interesse de toda a coletividade (interesse público primário). Desta forma, ainda que o crédito tributário esteja sendo questionado e que o deslinde da referida demanda possa parecer favorável ao fisco, ainda assim poderia se justificar a transação tributária como forma de composição do litígio ${ }^{360}$.

É que tal solução implicaria, por exemplo, em redução de despesas da Administração Pública como um todo, nas suas mais diversas esferas de atuação. A solução amigável de um litígio otimiza os gastos com o Poder Judiciário e com o próprio Poder Executivo, incumbido de defender a Administração e até de recursos materiais como papel e tinta, transporte, etc $^{361}$.

Superada a discussão acerca da indisponibilidade do interesse público como obstáculo para a transação em matéria tributária, passemos agora à análise da

\footnotetext{
${ }^{359}$ Sobre a possibilidade de transação pela Administração em matéria de Direito Público e suposto conflito com o princípio da indisponibilidade do interesse público, conferir item 2.2.2 deste trabalho.

${ }^{360}$ Segundo Luís Eduardo Schoueri: "Ao mesmo tempo, não se pode negar que não é interesse sequer do Fisco que uma disputa judicial fique se arrastando por anos, entulhando os tribunais e prorrogando indefinidamente o eventual recebimento do crédito tributário." $\mathrm{E}$ acrescenta: "Tem-se, aqui, uma conciliação entre, de um lado, o Princípio da Legalidade, que exige a presença de uma lei para que se dê a transação e, de outro, o interesse público, que muitas vezes será mais bem atendido se forem encurtadas as demandas judiciais, por meio da transação". (SCHOUERI, Luís Eduardo. Direito Tributário. São Paulo: Saraiva, 2013, p. 622).

${ }^{361}$ Acerca do custo unitário do processo de execução fisscal na Justiça Federal, vide Comunicado do IPEA $\mathrm{n}^{\circ}$ 127, de 04 de janeiro de 2012. Nesse relatório, o IPEA destaca que uma execução fiscal custa, em média, R \$ 5.607,67. Disponível em: <http://www.ipea.gov.br/portal/images/stories/PDFs/comunicado/120103comu nicadoipea127.pdf $>$. Acesso em: 17 fev. 2013.
} 
obrigatoriedade das atividades de lançamento e cobrança do crédito tributário pelo físco, como decorrência dos arts. $3^{\circ}$ e $142, \S$ único, do CTN. Para melhor compreender esse argumento, necessária uma análise dos dispositivos que tratam dessa questão no CTN.

Em observância ao disposto no artigo 146, caput, inciso III, da $\mathrm{CF} / 88$, o art. $3^{\circ}$ do CTN definiu tributo como "toda prestação pecuniária, compulsória, em moeda ou cujo valor nela se possa exprimir, que não constitua sanção de ato ilícito, instituída em lei e cobrada mediante atividade administrativa plenamente vinculada" ${ }^{\prime 62}$. Por sua vez, o art. 142, § único, do CTN estabeleceu que "a atividade administrativa de lançamento é vinculada e obrigatória, sob pena de responsabilidade funcional" do auditor-fiscal responsável pelo lançamento.

Da leitura desses dispositivos depreende-se que a obrigação tributária é uma obrigação compulsória que nasce por força de lei. Ocorrido o fato gerador, nasce a obrigação prevista na norma que impõe ao sujeito passivo o dever de recolher o tributo aos cofres públicos. Não o fazendo voluntariamente, compete ao fisco obrigatoriamente efetuar o lançamento tributário (art. 142, § único, do CTN). Em seguida, deverá proceder ao início dos procedimentos de cobrança administrativa e, posteriormente, judicial, por meio da competente ação de execução fiscal (art. $3^{\circ} \mathrm{CTN}$, in fine $)^{363}$.

Em vista do caráter obrigatório do lançamento e da vinculação da Administração à atividade de cobrança do crédito tributário é que muitos autores sustentam que a transação em matéria tributária não poderia ocorrer em nosso sistema. O próprio Rubens Gomes de Sousa, um dos autores do anteprojeto do CTN, entendia que a transação era inaplicável (ou aplicável excepcionalmente) no âmbito do Direito Tributário brasileiro, uma vez que a atividade do lançamento seria vinculada e obrigatória, de modo que o fisco não poderia fazer concessões ${ }^{364}$. Eurico Diniz de Santi, por sua vez, sustenta que a

${ }^{362}$ De acordo com a doutrina majoritária, o CTN teria sido recepcionado pela Constituição Federal de 1988 com força de Lei Complementar. Nesse sentido é o posicionamento, entre outros, de Luís Eduardo Schoueri, para quem: "[...] Conquanto editado sob a forma de lei ordinária (Lei $\left.\mathrm{n}^{\circ} 5.172 / 1966\right)$, a matéria que ele regulou é, hoje, por força do artigo 146 acima referido, reservada pela Constituição à lei complementar. Por tal razão, apenas uma lei complementar poderia inovar em tais matérias. Quando legislação anterior regula matéria de modo que não contraria o novo texto constitucional, ocorre o fenômeno da recepção [...]. Nesse sentido, o Código Tributário nacional, do ponto de vista material, tem eficácia de lei complementar." (SCHOUERI, Luís Eduardo. Direito Tributário. São Paulo: Saraiva, 2013, p. 72-73).

${ }^{363}$ Isso evidentemente se não houver impugnação administrativa ao lançamento tributário. É que, em conformidade com o disposto no art. 151, III do CTN, suspendem a exigibilidade do crédito tributário, entre outros eventos, "as reclamações e os recursos, nos termos das leis reguladoras do processo tributário administrativo".

${ }^{364}$ Entretanto, reconhecia Rubens Gomes de Sousa que o sistema tributário brasileiro admitia uma exceção quanto aos tributos federais prevista pela Lei $\mathrm{n}^{\circ} 1.341 / 51$. (SOUSA, Rubens Gomes de. Compêndio de Legislação Tributária. Rio de Janeiro: Edições Financeiras, 1960, p. 94.) 
transação tributária, na forma como prevista no anteprojeto, configuraria "adulteração" do conceito de tributo, que pressupõe cobrança por atividade administrativa plenamente vinculada $^{365}$. Enfim, ainda na mesma linha é o entendimento de Eduardo Marcial Ferreira Jardim, para quem nem mesmo a lei poderia permitir a transação tributária em nosso sistema, na medida em que a discricionariedade imanente à transação não se coadunaria com os princípios da legalidade, tipicidade e vinculabilidade da tributação ${ }^{366}$

Em suma, fundamentando-se nos arts. $3^{\circ}$ e 142, § único, do CTN, parte da doutrina considera que, uma vez ocorrida a situação descrita na norma, o fisco não teria outra alternativa a não ser lançar e cobrar o tributo devido pelo sujeito passivo. Não poderia deixar de fazê-lo, na medida em que não haveria margem de discricionariedade para lançar, tampouco para cobrar o crédito tributário em troca de alguma concessão da outra parte. Enfim, para esta corrente doutrinária, não se admitiria a flexibilização do dever de efetuar o lançamento e em seguida cobrar o valor do tributo devido, mesmo que em busca da eficiência e da economicidade.

Esse posicionamento, todavia, não parece de todo correto, sendo vários os autores que o rechaçam. A título exemplificativo, Ricardo Lobo Torres considera que a complexidade e a dificuldade inerentes à apreensão e à interpretação dos conceitos indeterminados e dos tipos jurídicos existentes na legislação tributária já permitiria uma certa margem de apreciação da autoridade fiscal, quando da atividade do lançamento tributário $^{367}$. Rubens Miranda de Carvalho, por sua vez, sustenta que a regra da indisponibilidade do crédito tributário prevista nos dispositivos mencionados não seria absoluta, dando lugar à possibilidade de transação e à consequente disposição desses

\footnotetext{
${ }^{365}$ Nas palavras de Eurico Marcos Diniz de Santi: "Veja-se o que o indigitado anteprojeto altera no CTN. Inicia-se com o conceito de 'tributo' [...] A transação neste projeto ignora tais critérios, rompe o ciclo de positivação do direito e se auto-impõe como forma definitiva de cobrança e exigência do tributo, distorcendo o art. $3^{\circ}$ do CTN [...]". (SANTI, Eurico Marcos Diniz de. Transação e arbitragem no Direito Tributário: paranóia ou mistificação? In: FERRAZ, Roberto (Coord). Principios e limites da tributação 2 Os princípios da ordem econômica e a tributação. São Paulo: Quartier Latin, 2009, p. 610-611).

$366 \mathrm{Na}$ visão de Eduardo Marcial Ferreira Jardim: "Demais, nem mesmo a lei poderia atribuir à Administração Pública a prerrogativa de promover a transação, pois tal conjectura subverteria os primados cardinais do sistema tributário, assim como os princípios da legalidade, da vinculabilidade e o da tipicidade da tributação. Por sem dúvida, a transação antes supõe prática de ato administrativo discricionário, o que repugna, por todos os títulos, a cor vinculada da atividade administrativa de lançamento". (JARDIM, Eduardo Marcial Ferreira. Outras formas de extinção da obrigação tributária. In: MARTINS, Ives Gandra da Silva. Curso de Direito Tributário. São Paulo: Saraiva, 1982, p. 167). Essa visão foi recentemente corroborada pelo mesmo autor que afirma que "não há lugar para a transação [...], não padece dúvida de que o aludido instituto afigura-se incompatível com as premissas concernentes à tributação, dentre elas a necessária discricionariedade que preside a transação e a vinculabilidade que permeia toda a função administrativa relativa aos tributos." (JARDIM, Eduardo Marcial Ferreira. Arts. 170 a 172. In: MARTINS, Ives Gandra da Silva (Coord.). Comentários ao Código Tributário Nacional. São Paulo: Saraiva, 2013, v. 2, p. 512).
} 
créditos quando houver incertezas que justifiquem sua flexibilização ${ }^{368}$. Um outro argumento trazido por Helena Marques Junqueira para defender a compatibilidade do instituto da transação tributária com o conceito de tributo previsto na legislação brasileira consiste em que o art. $3^{\circ}$ do $\mathrm{CTN}$, ao estabelecer que a cobrança do tributo se dará por atividade administrativa plenamente vinculada, nada mais fez do que determinar que a cobrança seja efetuada nos termos da lei. E, se a lei permite a transação tributária, não haveria que se falar em violação a esse dispositivo ${ }^{369}$. Finalmente, Hugo de Brito Machado preconiza uma outra solução. $\mathrm{Na}$ sua opinião, a antinomia entre o art. $3^{\circ}$ do $\mathrm{CTN}$, que prevê a cobrança do tributo por atividade administrativa plenamente vinculada e o art. 171 do mesmo diploma, que permite a transação, seria uma antinomia apenas aparente, que poderia ser resolvida pelo critério da especialidade, prevalecendo este último, dado o seu caráter especial face à regra geral da cobrança mediante atividade vinculada ${ }^{370}$.

Tem-se, assim, que a parte final do art. $3^{\circ}$ do CTN, que prevê que o tributo deve ser cobrado mediante atividade plenamente vinculada, parece não impedir que a transação em matéria tributária ocorra em nosso ordenamento. Porém, ainda que se venha a admitir a impossibilidade de transação em relação aos tributos, por força desse dispositivo, nada impediria que essa viesse a ocorrer em relação aos seus acessórios, notadamente no que tange aos juros e à multa. É que, o art. $3^{\circ}$ do CTN, que vincula a autoridade administrativa, impondo-lhe a cobrança das prestações devidas pelo contribuinte, refere-

367 TORRES, Ricardo Lobo. Transação, conciliação e processo tributário administrativo equitativo. In: SARAIVA FILHO, Oswaldo Othon de Pontes; GUIMARÃES, Vasco Branco (Orgs.). Transação e Arbitragem no Direito Tributário. Belo Horizonte: Forum, 2008, p. 107. O autor pontua que, entre os instrumentos jurídicos capazes de excepcionar o princípio da indisponibilidade, encontram-se: (a) a discricionariedade administrativa - encontrada em alguns procedimentos necessários ao lançamento como a escolha de métodos de investigação, a ponderação de interesses e a necessidade de verificar os riscos físcais provocados pelo contribuinte; (b) a tipificação administrativa casuística - por meio da complementação normativa e do processo tributário administrativo; e (c) a quantificação da base de cálculo dos tributos: é o caso da determinação da preço de mercado nos preços de transparência.

${ }^{368}$ CARVALHO, Rubens Miranda de. Transação Tributária, Arbitragem e outras formas convencionadas de solução de lides tributárias. São Paulo: Juarez de Oliveira, 2008, p. 99-100.

${ }^{369}$ Nas palavras de Helena Marques Junqueira: "Efetivamente, entendemos que o conceito de tributo determina, antes de tudo, que a sua instituição seja feita por lei e, portanto, quando o Código Tributário impõe que a cobrança do tributo seja plenamente vinculada, implica dizer que a vinculação seja, exatamente, aos termos do que determina a lei. Portanto, a cobrança do tributo é ato administrativo plenamente vinculado às regras e limitações que a lei imponha." (JUNQUEIRA, Helena Marques. Transação Tributária. Tese (Doutorado em Direito), Faculdade de Direito da Pontifícia Universidade Católica de São Paulo, 2009, p. 180).

${ }^{370}$ MACHADO, Hugo de Brito. Transação e arbitragem no âmbito tributário. In: SARAIVA FILHO, Oswaldo Othon de Pontes; GUIMARÃES, Vasco Branco (Orgs.). Transação e Arbitragem no Direito Tributário. Belo Horizonte: Forum, 2008, p. 113. Segundo o autor: "Em outras palavras, o art. $3^{\circ}$ do Código Tributário Nacional contém uma prescrição jurídica aplicável à atividade de cobrança do tributo [...]. O art. 171, ao admitir a transação como forma de extinção do crédito tributário, contém uma prescrição especial, aplicável apenas aos casos e nas condições que a lei estabelecer. Uma exceção, portanto, à prescrição genérica." 
se tão somente ao tributo propriamente dito "que não é sanção por ato ilícito", nos termos do próprio dispositivo. Assim, esse dispositivo não teria o condão de impedir que a transação entre fisco e contribuinte viesse a ocorrer em relação aos juros e às multas.

Por fim, o art. 142, § único, do CTN tampouco impediria a transação em relação às prestações acessórias. Isso porque, em que pese esse dispositivo ser aplicável também aos juros e multas, pois que se refere ao lançamento, dispondo ser este vinculado e obrigatório, sob pena de responsabilidade funcional, nada impede que, após sua lavratura, a autoridade tributária venha a transigir em relação ao crédito nele consubstanciado, efetuando concessões ao contribuinte. A supor essa hipótese, a transação tributária somente poderia ocorrer após o lançamento tributário.

Em conclusão, em que pese os argumentos em sentido contrário, parece que tanto o art. $3^{\circ}$, quanto o art. $142, \S$ único, do CTN, que tratam da obrigatoriedade das atividades de lançamento e cobrança do crédito tributário, não impediriam per se a transação tributária entre fisco e contribuinte em nosso ordenamento. Essa conclusão ganha ainda mais força quando a referida transação tributária implicar não em redução do tributo propriamente dito, mas sim de seus acessórios (juros e multa), e quando for realizada após o lançamento tributário. Nessas hipóteses, parece que todos os argumentos em relação à indisponibilidade do crédito tributário caem definitivamente por terra.

\subsubsection{Caracterização como renúncia de receitas (art. 14 da LRF)}

Outro possível conflito que se coloca em relação à transação em matéria tributária face ao ordenamento jurídico brasileiro diz respeito à compatibilidade desse instituto com o disposto no art. 14 da Lei de Responsabilidade Fiscal ${ }^{371}$. Discute-se se a transação entre fisco e contribuinte, quando venha a reduzir o valor do tributo e/ou seus acessórios (e.g.

\footnotetext{
371 “Art. 14. A concessão ou ampliação de incentivo ou benefício de natureza tributária da qual decorra renúncia de receita deverá estar acompanhada de estimativa do impacto orçamentário-financeiro no exercício em que deva iniciar sua vigência e nos dois seguintes, atender ao disposto na lei de diretrizes orçamentárias e a pelo menos uma das seguintes condições:

I - demonstração pelo proponente de que a renúncia foi considerada na estimativa de receita da lei orçamentária, na forma do art. 12, e de que não afetará as metas de resultados fiscais previstas no anexo próprio da lei de diretrizes orçamentárias;

II - estar acompanhada de medidas de compensação, no período mencionado no caput, por meio do aumento de receita, proveniente da elevação de alíquotas, ampliação da base de cálculo, majoração ou criação de tributo ou contribuição.

$\S 1 \underline{\mathrm{O}}$ A renúncia compreende anistia, remissão, subsídio, crédito presumido, concessão de isenção em caráter não geral, alteração de alíquota ou modificação de base de cálculo que implique redução discriminada de tributos ou contribuições, e outros benefícios que correspondam a tratamento diferenciado $[\ldots] . "$
} 
multa, encargo legal e juros), poderia ser considerada como um beneficio de natureza tributária do qual decorra renúncia de receitas, para os fins do disposto em tal preceito legal, sujeitando sua adoção às condições ali estabelecidas.

Como é sabido, a LRF buscou prevenir e corrigir os desequilíbrios das contas públicas, prática até então normal e corriqueira no âmbito dos diversos entes da Administração, introduzindo normas voltadas para a responsabilidade na gestão administrativa. Impôs uma série de limitações e medidas a serem observadas pelos entes públicos $^{372}$. Uma dessas medidas implica, justamente, no maior controle em relação à renúncia de receitas por parte da Administração (também denominada de "gasto tributário"). Com efeito, a veiculação de benefícios tributários que impliquem em renúncia de receitas estará sujeita à observância de diversos requisitos ${ }^{373}$.

Decorre do art. 14 da LRF, que a concessão de incentivo ou benefício de natureza tributária da qual decorra renúncia de receita deverá (a) estar acompanhada de estimativa do impacto orçamentário-financeiro no exercício em que deva iniciar sua vigência e nos dois seguintes; (b) atender ao disposto na lei de diretrizes orçamentárias; e (c) estar acompanhada de demonstração de que a renúncia foi considerada na estimativa da receita orçamentária e de que não afetará as metas de resultados fiscais ou estar acompanhada de medidas de compensação que aumentem a receita.

Caso a transação em matéria tributária seja entendida como incentivo ou benefício de natureza tributária do qual decorra renúncia de receita para efeito do disposto no art. 14 da LRF, sua validade estará condicionada à presença dos requisitos acima mencionados. Do contrário, caso se entenda que a transação não se caracteriza como incentivo ou benefício de natureza tributária, as medidas constantes no art. 14 da LRF não serão aplicáveis.

De fato, o parágrafo $1^{\circ}$ do art. 14 da LRF não inclui expressamente a transação em matéria tributária entre as medidas compreendidas no termo benefício fiscal que implique renúncia de receita. Tal dispositivo faz referência tão somente à anistia, à remissão, ao subsídio, ao crédito presumido, à isenção e à modificação de alíquota ou

\footnotetext{
372 OLIVEIRA, Regis Fernandes de. Responsabilidade Fiscal. São Paulo: Revista dos Tribunais, 2002, p. 13.

373 Élcio Fiori Henriques utiliza o termo "mandamentos" para se referir às condições impostas pelo legislador para a concessão de benefícios fiscais que impliquem renúncia de receitas. (HENRIQUES, Élcio Fiori. Os beneficios fiscais no Direito Financeiro e Orçamentário: o Gasto Tributário no Direito Brasileiro. São Paulo: Quartier Latin, 2010, p. 129).
} 
base de cálculo que implique redução discriminada de tributos ou contribuições.

No entanto, isso por si só não significa que a transação esteja excluída, prescindindo, para sua concessão, das condições estabelecidas nesse dispositivo. Primeiramente, porque a formulação utilizada pelo legislador sugere uma enumeração não exaustiva dos benefícios fiscais que impliquem renúncia de receitas ${ }^{374}$. Além disso, em sua parte final, o legislador inseriu uma cláusula aberta capaz de estender os benefícios que impliquem renúncia de receitas, ao assim considerar outros beneficios que correspondam a tratamento diferenciado.

A abrangência da expressão "outros beneficios que correspondam a tratamento diferenciado" é bastante controvertida. Com efeito, considerando que a transação em matéria tributária pode dar ensejo a uma redução parcial do tributo e/ou de seus acessórios (juros e multa), bem como que sua celebração normalmente se daria somente em relação a um contribuinte ou a um grupo restrito de contribuintes, poderia se questionar se a transação pode ser considerada como um benefício que corresponda a tratamento tributário diferenciado, sujeito às limitações estabelecidas no art. 14 da LRF.

Poucos são os autores que ousaram enfrentar essa questão até o momento.

Oswaldo Othon de Pontes Saraiva Filho apenas tangencia a questão, asseverando que, quando a transação implicar renúncia de receitas, deverá ser observado o art. 14 da $\mathrm{LRF}^{375}$. Eurico de Santi, por sua vez, embora não trate especificamente da transação em matéria tributária propriamente dita, mas sim do anteprojeto de lei geral de transação em matéria tributária, afirma que a lógica do anteprojeto em questão seria incompatível com o disposto no art. 14 da $\mathrm{LRF}^{376}$.

Em sentido contrário, Hugo de Brito Machado entende que a transação em matéria tributária não pode ser enquadrada como benefício fiscal que implique renúncia de receita, para fins do art. 14 da LRF, por dois motivos: (a) um, em razão do elemento literal: a transação não poderia ser considerada como outros beneficios que corresponda tratamento diferenciado, haja vista seu caráter bilateral; (b) outro, em razão do elemento teleológico:

\footnotetext{
374 HENRIQUES, Élcio Fiori. Os beneficios fiscais no Direito Financeiro e Orçamentário: o Gasto Tributário no Direito Brasileiro. São Paulo: Quartier Latin, 2010, p. 142.

${ }^{375}$ SARAIVA FILHO, Oswaldo Othon de Pontes. A Transação e a arbitragem no direito constitucionaltributário brasileiro. In: SARAIVA FILHO, Oswaldo Othon de Pontes; GUIMARÃES, Vasco Branco (Orgs.). Transação e Arbitragem no Direito Tributário. Belo Horizonte: Forum, 2008, p. 78.

376 SANTI, Eurico Marcos Diniz de. Transação e arbitragem no Direito Tributário: paranóia ou mistificação? In: FERRAZ, Roberto (Coord). Principios e limites da tributação 2 - Os princípios da ordem econômica e a tributação. São Paulo: Quartier Latin, 2009, p. 623-624.
} 
a finalidade do artigo 14 da LRF foi evitar a concessão injustificada de vantagens que privem a Fazenda de receitas para a consecução de seus objetivos e não obrigar esta a levar um litígio até o fim ${ }^{377}$.

Esse parece ser também o entendimento da Corte Suprema brasileira sobre a questão. No julgamento da medida cautelar em sede da ADI $n^{\circ} 2405$, o Supremo Tribunal Federal entendeu pela implausibilidade da alegação de inconstitucionalidade da Lei $\mathrm{n}^{\mathrm{o}}$ 11.475/2000, que permitiu a transação em matéria tributária no Estado do Rio Grande do Sul. De acordo com o entendimento então manifestado, a transação seria uma forma de se colocar fim a um litígio, que pressupõe bilateralidade, e não um favor fiscal concedido unilateralmente ao contribuinte ${ }^{378}$.

E, embora não se estivesse nessa ação questionando a transação tributária instituída por aquela lei estadual em face do disposto no art. 14 da LRF, mas sim, principalmente, em face do art. $150, \S 6^{\circ}$, da $\mathrm{CF} / 88$, que dispõe que alguns benefícios fiscais enumerados naquele dispositivo necessitam de lei específica para serem concedidos, esse julgamento pode ser um indício do tratamento a ser dado à transação tributária: descartando-se a hipótese de ela configur um benefício que corresponda tratamento diferenciado, para fins do que dispõe o art. 14 da LRF.

Seja como for, mesmo que se venha a entender que transação em matéria tributária configura hipótese de renúncia de receitas, posto que se trata de um benefício que supostamente assegura um tratamento fiscal diferenciado àqueles que dela se beneficiam, ainda assim isso não seria empecilho para sua implementação em nosso sistema jurídico. Tampouco poderia se falar em incompatibilidade da transação em matéria tributária com o disposto no art. 14 da LRF, embora seja necessário reconhecer que sua caracterização como tal dificulta o procedimento de transação, impondo condições que podem porventura vir a limitar sua utilização na prática.

\footnotetext{
377 MACHADO, Hugo de Brito. Transação e arbitragem no âmbito tributário. In: SARAIVA FILHO, Oswaldo Othon de Pontes; GUIMARÃES, Vasco Branco (Orgs.). Transação e Arbitragem no Direito Tributário. Belo Horizonte: Forum, 2008, p. 119.

378 BRASIL. Supremo Tribunal Federal. Ação Direta de Inconstitucionalidade $\mathrm{n}^{\circ}$ 2405-MC, Relator Ministro Carlos Britto, j. 06/11/2002, DJ de 17/02/2006. Disponível em <http://redir.stf.jus.br/paginadorpub /paginador.jsp?docTP=AC\&docID=347580>. Acesso em: 13 fev. 2013. Note-se a esse respeito que o julgamento de mérito dessa ADI ainda não ocorreu encontrando-se os autos com o novo relator, Ministro Teori Zavascky, conforme informações do sítio eletrônico do STF. Disponível em: <http://www.stf.jus.br /portal/processo/verProcessoAndamento.asp?incidente=1902123 $>$. Acesso em: 13 fev. 2013. Sobre a transação tributária e a ADI n $n^{\circ}$ 2405-MC, conferir RISCADO JUNIOR, Paulo Roberto. Novos Caminhos para a Solução de Litígios Fiscais. In: Revista do Advogado. São Paulo, nº 94, Ano XXVII, novembro 2007, p. 139.
} 
Com efeito, basta que a transação tributária atenda ao disposto na lei de diretrizes orçamentárias e esteja acompanhada da estimativa de seu impacto orçamentáriofinanceiro, bem como que se apresente uma demonstração de que tal "renúncia" não afetará as metas de resultados fiscais para que ela se conforme às exigências legais. E, de fato, é bem provável que a transação tributária venha a ajudar a cumprir as metas de resultado anteriormente estabelecidas, pois que importará em uma entrada de recursos que, não fora ela, poderiam nunca ingressar aos cofres públicos ${ }^{379}$.

\subsubsection{Igualdade tributária (art. $5^{\circ}$, caput e 150, II da CF)}

Por fim, um último conflito da transação tributária em relação ao ordenamento jurídico pátrio a que faz menção a doutrina consiste no fato de que esse instituto supostamente violaria a igualdade ${ }^{380}$.

Isso porque, como já se teve a oportunidade de analisar nesse trabalho ${ }^{381}$, a transação em matéria tributária pressupõe concessões recíprocas de ambas as partes envolvidas (fisco e contribuinte). E, essas concessões podem, por parte do fisco, consistir em aceitar a redução dos valores devidos pelo sujeito ativo da obrigação tributária.

Some-se a isso o fato de que, dada sua natureza consensual, a transação tributária seria efetuada de maneira individualizada para cada contribuinte. Em outras palavras, as concessões propostas pelo físco para um contribuinte em determinado procedimento de transação não necessariamente seriam idênticas àquelas oferecidas a outros.

A possibilidade de redução do tributo, aliada à discricionariedade outorgada às autoridades competentes para oferecer ou aceitar os termos da transação e conjugada à análise casuística e individualizada de cada proposta de transação, faz com que parte da

\footnotetext{
379 CARVALHO, Rubens Miranda de. Transação Tributária, Arbitragem e outras formas convencionadas de solução de lides tributárias. São Paulo: Juarez de Oliveira, 2008, p. 198.

${ }^{380}$ SARAIVA FILHO, Oswaldo Othon de Pontes. A Transação e a arbitragem no direito constitucionaltributário brasileiro. In: SARAIVA FILHO, Oswaldo Othon de Pontes; GUIMARÃES, Vasco Branco (Orgs.). Transação e Arbitragem no Direito Tributário. Belo Horizonte: Forum, 2008, p. 44, 54, 56 e 69; SANTI, Eurico Marcos Diniz de. Transação e arbitragem no Direito Tributário: paranóia ou mistificação? In: FERRAZ, Roberto (Coord). Princípios e limites da tributação 2 - Os princípios da ordem econômica e a tributação. São Paulo: Quartier Latin, 2009, p. 624-626; MICHELIN, Dolizete Fátima. O anteprojeto da Lei Geral de Transação em Matéria Tributária e os princípios constitucionais da legalidade, isonomia e moralidade pública. In: SARAIVA FILHO, Oswaldo Othon de Pontes; GUIMARÃES, Vasco Branco (Orgs.). Transação e Arbitragem no Direito Tributário. Belo Horizonte: Forum, 2008, p. 348-353. Sobre a suposta violação da transação ao princípio da igualdade a autora questiona: "Como justificar o tratamento diferenciado que poderia ser dispensado a determinado contribuinte/devedor e não a outro, que esteja em situação similar?"

${ }^{381}$ A esse respeito, conferir item 3.2.2 deste trabalho.
} 
doutrina questione esse instituto em face do princípio da igualdade ${ }^{382}$.

O princípio da igualdade tem previsão constitucional no art. $5^{\circ}$, caput, da $\mathrm{CF} / 88$ : "Todos são iguais perante a lei, sem distinção de qualquer natureza, garantindo-se aos brasileiros e estrangeiros [...]”'. Em matéria tributária, o princípio da igualdade encontrase traduzido no art. 150, II, da $\mathrm{CF} / 88$, que veda aos entes políticos a instituição de tratamento desigual entre contribuintes que se encontrem em situações equivalentes.

O conteúdo e a abrangência do princípio da igualdade (de maneira geral e, também, em matéria tributária), é tema bastante complexo, sendo objeto recorrente de livros e artigos doutrinários ${ }^{383}$. Dada essa complexidade, ao tratar da transação e processo tributário equitativo, Ricardo Lobo Torres chega a afirmar que "O mais difícil princípio de legitimação é [justamente] o da igualdade [...]"384.

Analisando a doutrina, exsurgem alguns aspectos acerca do princípio da igualdade que parecem importantes na análise de sua compatibilidade com a transação tributária: (a) primeiro, que igualdade não significa identidade absoluta ${ }^{385}$; (b) segundo, que, sendo relativa, faz-se necessário analisar a igualdade sempre em relação a um critério $^{386}$; (c) terceiro, que deve ser dado igual tratamento às mesmas situações e um tratamento diferente para situações distintas ${ }^{387}$; (d) quarto, que, para tanto, é imprescindível uma análise pormenorizada das particularidades de cada situação ${ }^{388}$.

Em matéria de transação tributária, deve-se ressaltar que cada litígio terá suas próprias peculiaridades. Compete à autoridade administrativa com competência para transacionar analisar as particularidades e características de cada conflito que lhe for

\footnotetext{
382 JUNQUEIRA, Helena Marques. Transação Tributária. Tese (Doutorado em Direito), Faculdade de Direito da Pontifícia Universidade Católica de São Paulo, 2009, p. 169.

${ }^{383}$ Não se pretende nesse trabalho aprofundar acerca do princípio da igualdade em matéria tributária, mas tão somente trazer algumas de suas características para que se compreenda se a transação em matéria tributária poderá (ou não) afetá-lo. Para uma análise detalhada do princípio da igualdade tributária, conferir ÁVILA, Humberto. Teoria da Igualdade Tributária. São Paulo: Malheiros, 2009; e NABAIS, José Casalta. O Dever Fundamental de Pagar Impostos. Coimbra: Almedina, 2009, p. 435-524.

384 TORRES, Ricardo Lobo. Transação, conciliação e processo tributário administrativo equitativo. In: SARAIVA FILHO, Oswaldo Othon de Pontes; GUIMARÃES, Vasco Branco (Orgs.). Transação e Arbitragem no Direito Tributário. Belo Horizonte: Forum, 2008, p. 97.

${ }^{385}$ SCHOUERI, Luís Eduardo. Direito Tributário. São Paulo: Saraiva, 2013, p. 328; ROMANO, Carlo. Advance Tax Rulings and Principles of Law: Towards an European Tax Ruling System. [S.1.]: IBFD, v. 4, p. 318 .

${ }^{386}$ SCHOUERI, Luís Eduardo. op. cit., p. 329-330. Humberto Ávila parece ir na mesma linha, porém utiliza a expressão "medida de comparação" (ÁVILA, Humberto. op. cit., p. 43-44).

387 ROMANO, Carlo. Advance Tax Rulings and Principles of Law: Towards an European Tax Ruling System. [S.1.]: IBFD, v.4, p. 318.

${ }^{388}$ ÁVILA, Humberto. op. cit., p. 194.
} 
submetido, bem como a situação específica de cada contribuinte e as possíveis implicações da transação. Somente a partir dessa análise é que será possível avaliar os termos e condições do acordo a ser proposto (ou aceito) ao contribuinte interessado ${ }^{389}$.

Com efeito, verifica-se que o argumento segundo o qual a transação tributária violaria o princípio da igualdade, na medida em que reduziria o valor do crédito tributário de determinado contribuinte, assegurando-lhe um tratamento diferenciado em relação aos seus pares, não é de todo verdadeiro. Isso porque, conforme visto, é da essência do próprio princípio da igualdade tratar igualmente os iguais e desigualmente os desiguais. Assim, a análise casuística de cada proposta de transação pelo fisco não somente está conforme, como também fundamenta-se no próprio princípio da igualdade.

Aliás, cabe ressaltar que, assim como os princípios da proporcionalidade e da razoabilidade $^{390}$, a igualdade também possui um papel importante na limitação da discricionariedade administrativa ${ }^{391}$. Constatando diferenças entre as situações dos contribuintes, a margem de liberdade da autoridade competente para transacionar estará de certa forma limitada. Deverá tratá-los desigualmente, de forma a eliminar (ou, ao menos, amenizar) as diferenças existentes em cada caso. Inexistindo qualquer diferença, porém, deverá assegurar o mesmo tratamento, propondo as mesmas condições de acordo.

Com o intuito de garantir a igualdade de tratamento aos contribuintes que se encontrem na mesma situação, em observância ao princípio da igualdade, parte da doutrina - com a qual, diga-se, concordamos em sua integralidade - propõe a formação de um banco de dados contendo a situação concreta dos principais casos submetidos à transação e a solução a eles acordada. Tal conduta permitiria não somente a homogeneização e transparência das decisões proferidas pelas autoridades administrativas competentes para transacionar, como também evitaria tratamento diferenciado a contribuintes que se encontrem na mesma situação, inibindo favorecimentos ${ }^{392}$.

\footnotetext{
389 JUNQUEIRA, Helena Marques. Transação Tributária. Tese (Doutorado em Direito), Faculdade de Direito da Pontifícia Universidade Católica de São Paulo, 2009, p. 172.

${ }^{390}$ A esse respeito, conferir itens 2.2 .4 e 2.2.5 desse trabalho.

391 ROMANO, Carlo. Advance Tax Rulings and Principles of Law: Towards an European Tax Ruling System. [S.1.]: IBFD, v.4, p. 318.

392 MORAIS, Carlos Yuri Araújo. Transação e arbitragem em matéria tributária. In: SARAIVA FILHO, Oswaldo Othon de Pontes; GUIMARÃES, Vasco Branco (Orgs.). Transação e Arbitragem no Direito Tributário. Belo Horizonte: Forum, 2008, p. 501. Nesse mesmo sentido, Helena Marques Junqueira destaca, ainda, que a formação de um banco de dados das transações efetuadas minimizaria a corrupção, em decorrência do maior controle dos cidadãos. Ademais, assevera que essa iniciativa promoveria a economia procedimental, pois que o conhecimento prévio dos resultados obtidos em procedimentos análogos evitaria a movimentação desnecessária da Administração. (JUNQUEIRA, Helena Marques. op. cit., p. 173). Não propondo a criação específica de um banco de dados, mas propondo a transparência a e publicidade como
} 
A esse respeito, ousa-se ir um pouco mais além. O banco de dados proposto é certamente muito útil, mas talvez não seja suficiente para o propósito de assegurar a igualdade. $\mathrm{O}$ ideal parece ser dar publicidade e transparência não somente aos principais casos submetidos à transação, como a toda e qualquer decisão concessiva ou denegatória da transação tributária. Isso permitiria o conhecimento, por parte dos demais contribuintes, do tratamento tributário que está sendo dado pelo fisco a seus pares. E, eventualmente, caso comprovada a situação de igualdade entre as circunstâncias dos casos, permitiria que se exigisse um tratamento idêntico ou semelhante.

Não se desconhece que a publicação da situação fática e da solução acordada em matéria de procedimentos tributários é bastante controvertida no Direito Tributário nacional e estrangeiro. É que, ela contrapõe interesses conflitantes: de um lado, a transparência e a igualdade de tratamento; de outro, o sigilo e a confidencialidade das informações dos contribuintes ${ }^{393}$. Tal preocupação, no entanto, não se dá exclusivamente em relação à transação tributária, manifestando-se também em relação a outros instrumentos de contratualismo entre fisco e contribuinte como o ruling. A observância da igualdade nesses procedimentos tem feito com que se propugne pela necessidade de sua publicação assim como eventual extensão de seus efeitos para terceiros ${ }^{394}$.

Em conclusão, verifica-se que a transação em matéria tributária por si só não viola o princípio da igualdade previsto nos arts. $5^{\circ}$, caput e 150 , II da CF/88, ainda que porventura venha a reduzir o valor do crédito tributário de determinado contribuinte. A decisão individualizada, conforme as circunstâncias de cada caso concreto, é da essência do princípio da igualdade, que pressupõe o dever de diferenciação em conformidade com as particularidades de cada qual. Finalmente, nesse aspecto, importa destacar que a transparência e a publicidade possuem um papel de suma importância para a verificação da igualdade das situações. A publicidade é essencial para assegurar a transparência e permitir um maior controle dos cidadãos, além de garantir a própria igualdade.

\footnotetext{
mecanismos para evitar um tratamento discriminatório e antiisonômico, conferir também SARAIVA FILHO, Oswaldo Othon de Pontes. A transação e a arbitragem no direito constitucional-tributário brasileiro. In: SARAIVA FILHO, Oswaldo Othon de Pontes; GUIMARÃES, Vasco Branco (Orgs.). Transação e Arbitragem no Direito Tributário. Belo Horizonte: Forum, 2008, p. 56; e CARVALHO, Rubens Miranda de. Transação Tributária, Arbitragem e outras formas convencionadas de solução de lides tributárias. São Paulo: Juarez de Oliveira, 2008, p. 42.

393 ROMANO, Carlo. Advance Tax Rulings and Principles of Law: Towards an European Tax Ruling System. [S.1.]: IBFD, v.4, p. 319.

${ }^{394}$ Ibid., p. 492.
} 


\subsection{Desafios da transação em matéria tributária no contexto brasileiro}

Conforme visto na introdução desse trabalho, algumas das principais vantagens da transação tributária seriam a redução da litigiosidade, a desobstrução do Poder Judiciário com a consequente celeridade da solução dos litígios e a redução dos custos relacionados aos processos judiciais ${ }^{395}$. Além destas, podem ser destacadas também outras analisadas no decorrer do trabalho, tais como: a maior participação dos contribuintes na Administração; e a eficiência na gestão administrativo-tributária ${ }^{396}$.

No entanto, apesar das seguras vantagens que o instituto traria, a transação em matéria tributária não está isenta de críticas. Muito pelo contário. Apenas para destacar alguns dos principais desafios apontados pela doutrina, podem ser citados: o desestímulo ao pagamento voluntário dos tributos e seus acessórios (item 3.4.1); e a possibilidade de cometimento de abusos em razão do excesso de discricionariedade (item 3.4.2). Serão, pois, esses desafios que serão analisados a seguir.

\subsubsection{Desestímulo ao pagamento voluntário}

A idéia de transação tributária pressupõe uma concessão por parte da autoridade fiscal. Esta concessão normalmente consiste na redução dos juros e multas, bem como, em alguns casos, também do encargo legal e até honorários advocatícios. Em contrapartida, o contribuinte efetua o pagamento imediato dos valores devidos e renuncia às discussões, pondo fim à controvérsia existente ${ }^{397}$.

É verdade que o contribuinte, assim como a Fazenda, tem interesse na solução rápida de seus litígios, preza pela sua participação na Administração e beneficia-se, direta ou indiretamente, das outras vantagens da transação. Porém, talvez o principal atrativo do contribuinte em realizar a transação tributária consista no fato de que ela normalmente

\footnotetext{
${ }^{395}$ Para Oswaldo Othon de Pontes Saraiva Filho, a excessiva litigiosidade e a morosidade judiciária poderia ser contornada de forma mais eficaz, por meio de investimentos em estruturas já existentes no âmbito da Administração tributária, de maneira a melhor aparelhá-la, como também com a criação de instrumentos processuais mais ágeis, como a diminuição das hipóteses de cabimento de recursos. (SARAIVA FILHO, Oswaldo Othon de Pontes. A transação e a arbitragem no direito constitucional-tributário brasileiro. In: SARAIVA FILHO, Oswaldo Othon de Pontes; GUIMARÃES, Vasco Branco (Orgs.). Transação e Arbitragem no Direito Tributário. Belo Horizonte: Forum, 2008, p. 77).

${ }^{396}$ MARTINS FILHO, Luiz Dias; ADAMS, Luís Inácio Lucena. A transação no Código Tributário nacional (CTN) e as novas propostas normativas de leis autorizadoras. In: SARAIVA FILHO, Oswaldo Othon de Pontes; GUIMARÃES, Vasco Branco (Orgs.). Transação e Arbitragem no Direito Tributário. Belo Horizonte: Forum, 2008, p. 37-38.

${ }^{397}$ Acerca das concessões mútuas como pressuposto da transação em matéria tributária, conferir item 3.2.2 deste trabalho.
} 
implica no pagamento de valores inferiores àqueles originalmente cobrados pelo fisco ${ }^{398}$.

Com efeito, um dos principais desafios em relação à transação tributária é que sua implementação pode vir a desestimular o pagamento voluntário de tributos pelos contribuintes $^{399}$. É que, ciente de que a Administração fiscal teria por prática celebrar transações tributárias, os contribuintes teriam menos interesse em pagar espontaneamente os tributos quando de seus vencimentos, preferindo tentar, posteriormente, os benefícios de uma eventual transação, com as reduções a ela inerentes ${ }^{400}$.

De fato, a transação em matéria tributária pode ter por consequência o efeito de desestimular o pagamento voluntário dos tributos pelos contribuintes ${ }^{401}$. Esse problema, todavia, não se restringe somente à transação tributária, abrangendo também outros institutos de Direito Tributário, como o parcelamento, a remissão e a anistia fiscal ${ }^{402}$. Por exemplo, o governo federal edita leis instituindo planos de parcelamento de débitos que contemplam a redução de multa e juros, o que historicamente tem ocorrido a cada três ou quatro anos ${ }^{403}$. Baseando-se nisso, alguns contribuintes preferem deixar de pagar seus tributos contando com as benesses desses "planos de parcelamento"

398 JUNQUEIRA, Helena Marques. Transação Tributária. Tese (Doutorado em Direito), Faculdade de Direito da Pontifícia Universidade Católica de São Paulo, 2009, p. 181.

399 SARAIVA FILHO, Oswaldo Othon de Pontes. A transação e a arbitragem no direito constitucionaltributário brasileiro. In: SARAIVA FILHO, Oswaldo Othon de Pontes; GUIMARÃES, Vasco Branco (Orgs.). Transação e Arbitragem no Direito Tributário. Belo Horizonte: Forum, 2008, p. 65.

${ }^{400}$ Nesse sentido, Eurico Diniz de Santi faz a seguinte indagação: “[...] Mas se for assim, porque os outros contribuintes pagaram tributo em seu valor nominal e antes? Não seria melhor transacionar sempre? [...]" (SANTI, Eurico Marcos Diniz de. Transação e arbitragem no Direito Tributário: paranóia ou mistificação? In: FERRAZ, Roberto (Coord). Principios e limites da tributação 2 - Os princípios da ordem econômica e a tributação. São Paulo: Quartier Latin, 2009, p. 605).

${ }^{401}$ MICHELIN, Dolizete Fátima. O anteprojeto da Lei Geral de Transação em Matéria Tributária e os princípios constitucionais da legalidade, isonomia, e moralidade. In: SARAIVA FILHO, Oswaldo Othon de Pontes; GUIMARÃES, Vasco Branco (Orgs.). Transação e Arbitragem no Direito Tributário. Belo Horizonte: Forum, 2008, p. 342-343. Segundo a autora, em palestra proferida pelo Prof. Vincenzo Busa, da Administração tributária italiana, durante o Seminário Internacional "A Proposta de Lei Geral de Transação: Lealdade e Confiança nas Relações Tributárias", o prof. italiano salientou que : “[...] seria um risco utilizar tal medida como um instrumento para aumentar a arrecadação ou uma alternativa para o autolançamento, porque pode haver um desestímulo ao pagamento espontâneo [...]".

${ }^{402}$ A esse respeito, Sacha Calmon pontua que: "A prática indiscriminada de remissões conjugadas com anistias, ou até mesmo da anisitia como estímulo para o pagamento de tributo não-pago, é vista com profundas reservas pela sociedade dos bons pagadores. A espera sistemática por anistias estimula o inadimplemento das obrigações tributárias e, ao mesmo tempo, irrita os que, espontaneamente, cumpriram suas obrigações, ainda que com atraso, ou seja, pagando multa." (COÊLHO, Sacha Calmon Navarro. Curso de Direito Tributário Brasileiro. Rio de Janeiro: Forense, 2012, p. 766).

${ }^{403}$ Ao longo dos últimos anos, o governo federal instituiu vários programas de parcelamento de débitos tributários federais. São eles: (a) "REFIS", instituído pela Lei n 9.964/2000; (b) "PAES", instituído pela Lei n ${ }^{\circ}$ 10.684/2003; (c) "PAEX", instituído pela MP n 303/2006; (d) "REFIS da crise", instituído pela Lei $\mathrm{n}^{\circ}$ 11.941/2009 (conversão da MP 449/2008). Mais recentemente, após a aprovação, pelo Congresso Nacional, da reabertura do prazo para adesão ao REFIS da crise, a Presidente Dilma decidiu vetar o dispositivo. Há quem diga, no entanto, que outro parcelamento já estaria por vir.

${ }^{404}$ Note que a natureza jurídica dos benefícios concedidos por essas leis que instituem os denominados 
Ao deixar de recolher voluntariamente seus tributos, optando por uma eventual transação, o contribuinte assume um risco, pois que o físco não está obrigado a transacionar. Tem ele discricionariedade para fazê-lo ou não, em conformidade com o interesse público. Caso a transação não se realize por qualquer motivo, deverá o contribuinte arcar com as penalidades inerentes ao seu pagamento a destempo. Porém, quando já estiver com seus débitos em atraso, aí sim realmente não haverá nenhuma consequência mais desvantajosa, acarretando o dever de pagar o que já era devido ${ }^{405}$.

Finalmente, cabe à Administração avaliar se a transação tributária efetivamente desestimula o pagamento voluntário dos tributos no caso concreto. Ao fazê-lo, deve sopesar o risco de perda de arrecadação voluntária perante os ganhos concretos trazidos pela transação. É que, a transação implica, no mais das vezes, na redução dos custos de manutenção do Estado (e.g. Poder Judiciário e Advocacia-Pública estatal). Demais disso, contribui para a segurança jurídica do contribuinte e mesmo para a previsibilidade de suas relações jurídicas. Enfim, ainda que haja, de fato, um desestímulo ao pagamento voluntário, as vantagens da transação podem vir a compensar a perda da arrecadação ${ }^{406}$.

\subsubsection{Excesso de discricionariedade e desvios na sua utilização}

Já foi visto que, em regra, podem ser diferenciadas duas situações em relação à transação pela Administração: (i) uma, em que a lei especificaria todos os contornos do acordo a ser celebrado, detalhando seus termos e condições e não deixando qualquer margem valorativa à Administração; e (ii) outra, em que, por não poder prever todas as circunstâncias da transação, a lei atribuiria uma margem de discricionariedade à Administração para que essa celebrasse a transação de acordo com sua conveniência e oportunidade $^{407}$.

Além disso, já se analisou o disposto no art. 171 do CTN, que dispõe que a realização da transação em matéria tributária depende de lei, chegando-se à conclusão que a lei a que se referiu o dispositivo poderia ser genérica, de forma que atribuisse uma

planos de parcelamento é bastante controvertida. Uma parte da doutrina acredita ser, de fato, um parcelamento, conjugado com anistia e até remissão de débitos. Outra parte acredita que o benefício previsto nessas leis seja, em realidade, uma transação.

${ }^{405}$ SARAIVA FILHO, Oswaldo Othon de Pontes. A transação e a arbitragem no direito constitucionaltributário brasileiro. In: SARAIVA FILHO, Oswaldo Othon de Pontes; GUIMARÃES, Vasco Branco (Orgs.). Transação e Arbitragem no Direito Tributário. Belo Horizonte: Forum, 2008, p. 65.

406 JUNQUEIRA, Helena Marques. Transação Tributária. Tese (Doutorado em Direito), Faculdade de Direito da Pontifícia Universidade Católica de São Paulo, 2009, p. 182.

${ }^{407}$ A esse respeito, conferir item 2.2.4 e 2.2.5 deste trabalho. 
margem de discricionariedade à Administração tributária para celebrar a transação ${ }^{408}$. A atribuição de discricionariedade à Administração parece ser da própria essência do instituto da transação (inclusive tributária), que pressupõe concessões mútuas, o que implica a possibilidade da Administração negociar as cláusulas da transação ${ }^{409}$.

É justamente na discricionariedade atribuída à Administração tributária que reside um outro desafio ao instituto da transação tributária. Isso porque, considera-se que o excesso de discricionariedade centrado na mão do fisco pode gerar desvios na utilização desse importante instrumento de resolução de conflitos. Nesse sentido, Eurico Diniz de Santi destaca que a transação em matéria tributária seria "incompatível com nossa realidade sociopolítica e cultural" e que esse instituto poderia ensejar a "juridicização da corrupção sistêmica" ${ }^{\text {"410 }}$. Oswaldo Othon Saravia Filho, por sua vez, acrescenta um outro problema: sua utilização como "instrumento político"411.

Em resposta a essas afirmativas, primeiramente, importa enfatizar que a atribuição de discricionariedade para que a Administração tributária celebre transação não significa a outorga de ampla e irrestrita margem de liberdade; tampouco ausência de limitações à atividade discricionária do fisco. Discricionariedade não se confunde com arbitrariedade. Ao celebrar (ou não) a transação, a autoridade competente deverá se pautar em diretrizes previamente delineadas pela lei e observar alguns princípios de direito, entre os quais o da razoabilidade e o da proporcionalidade. Além disso, a autoridade deverá sempre motivar sua escolha. Isso, por si só, já permite um certo controle dessa atividade, inibindo a corrupção e a utilização da transação como instrumento político.

Tais limites é certo, embora inibam esses desvios, não eliminam a possibilidade de utilização desse instrumento em favor de determinados contribuintes em troca de dinheiro ou de apoio político. O ser humano, como tal, é corrompível. Além do mais, a discricionariedade aliada aos consideráveis valores envolvidos na transação pode, sem

\footnotetext{
408 BATISTA JÚNIOR, Onofre Alves. Transação no Direito Tributário, discricionariedade e interesse público. Revista Dialética de Direito Tributário. São Paulo: Dialética, n. 83, ago. 2002, p. 122. Em sentido contrário é o posicionamento de Luís Eduardo Schoueri. (SCHOUERI, Luís Eduardo. Direito Tributário. São Paulo: Saraiva, 2013, p. 623).

409 JUNQUEIRA, Helena Marques. Transação Tributária. Tese (Doutorado em Direito), Faculdade de Direito da Pontifícia Universidade Católica de São Paulo, 2009, p. 116-117.

410 SANTI, Eurico Marcos Diniz de. Transação e arbitragem no Direito Tributário: paranóia ou mistificação? In: FERRAZ, Roberto (Coord). Principios e limites da tributação 2 - Os princípios da ordem econômica e a tributação. São Paulo: Quartier Latin, 2009, p. 607 e 626.

${ }^{411}$ SARAIVA FILHO, Oswaldo Othon de Pontes. A transação e a arbitragem no direito constitucionaltributário brasileiro. In: SARAIVA FILHO, Oswaldo Othon de Pontes; GUIMARÃES, Vasco Branco (Orgs.). Transação e Arbitragem no Direito Tributário. Belo Horizonte: Forum, 2008, p. 44.
} 
dúvida nenhuma, favorecer a corrupção da autoridade competente para transacionar ${ }^{412}$. Enfim, não se desconhece que o excesso de discricionariedade atribuído aos agentes com competência para transacionar pode dar ensejo à oportunidade de corrupção ou mesmo sua utilização como instrumento político de favorecimento de determinados contribuintes.

Tal argumento, no entanto, não pode impedir que se venha a adotar esse instrumento de resolução de conflitos em nosso ordenamento jurídico. Primeiro, porque a corrupção é um mal que pode atacar qualquer órgão: seja na esfera pública ou privada, sempre haverá pessoas capazes de se valer de seus cargos e de suas atribuições para favorecer terceiros em troca de benefícios pessoais. Segundo porque, como destacado por Hugo de Brito Machado, a corrupção existe mesmo na fórmula legalista atual ${ }^{413}$, em que a criação de tributos ou redução dos mesmos depende de lei. Terceiro, porque manter a resolução de conflitos tributários no Judiciário ou limitar a possibilidade de redução do crédito tributário somente pelo Legislativo não isenta a sociedade da corrupção, pois que a experiência em nosso país demonstra que tanto um quanto o outro também são susceptíveis a este $\mathrm{mal}^{414}$. Quarto, porque já existem, na atualidade mecanismos de controle da atividade estatal, que podem também vir a ser utilizados para fiscalizar eventuais desvios em relação à atuação da autoridade fiscal quando da transação tributária; entre esses mecanismos, destacam-se: (a) os instrumentos de controle: é o caso, por exemplo, das ações populares, ações civis públicas, mandados de segurança, etc; e (b)

412 JUNQUEIRA, Helena Marques. Transação Tributária. Tese (Doutorado em Direito), Faculdade de Direito da Pontifícia Universidade Católica de São Paulo, 2009, p. 188.

${ }^{413}$ MACHADO, Hugo de Brito. Transação e arbitragem no âmbito tributário. In: SARAIVA FILHO, Oswaldo Othon de Pontes; GUIMARÃES, Vasco Branco (Orgs.). Transação e Arbitragem no Direito Tributário. Belo Horizonte: Forum, 2008, p. 126. Nesse sentido, o referido autor sustenta que o argumento da corrupção é: "[...] aparentemente válido. Validade apenas aparente. A corrupção não deixa de existir na fórmula legalista que prevalece atualmente em nosso sistema jurídico". A esse respeito, todavia, imprescindível ressaltar que o referido autor parece ter mudado sua opinião quando analisou o anteprojeto de Lei Geral de Transação em matéria tributária. É que, em consulta formulada pela Unafisco - Sindicato Nacional dos Auditores-Fiscais da Receita Federal do Brasil, em 20 de agosto de 2009, o professor, juntamente com Hugo de Brito Machado Segundo, concluem que: "[...] a discricionariedade conferida à Administração Tributária, além de ser contrária ao princípio da legalidade, dá espaço para a prática de corrupção e agride o interesse público. Essa 'maleabilidade', ainda que não seja utilizada para a prática de corrupção, poderá transformar o tributo em instrumento político, com a redução de ônus em troca de apoio ao governo.” Disponível em: http://www.sindifisconacional.org.br/mod_download.php?id=L2ltYWdlcy9lc3 R1ZG9zL3BhcmVjZXIvUGFyZWNlckh1Z29kZUJyaXRvTEdULnBkZnww.Acesso em: 15 dez. 2012.

${ }^{414}$ Evidência da corrupção no Judiciário é o escândalo decorrente do desvio de recursos para a construção do Fórum Trabalhista de São Paulo pelo juiz Nicolau dos Santos Neto (conhecido como "Lalau"). Outra evidência de corrupção se deu no escândalo que deu origem à operação Anaconda, que tratava da venda de sentenças pelo juiz Rocha Mattos. A esse respeito, conferir VASCONCELOS, Frederico. Juizes no Banco dos Réus. São Paulo: Publifolha, 2005. A corrupção no Legislativo ganhou notoriedade no denominado "Mensalão", esquema que foi recentemente reconhecido pelo Supremo Tribunal Federal quando do julgamento da Ação Penal $\mathrm{n}^{\circ}$ 470, cuja conclusão do julgamento se deu em 17.12.2012 após aproximadamente 4 meses e meio de debates e julgamento. 
os órgãos de controle e fiscalização da atividade administrativa: é o caso das corregedorias, das controladorias, dos tribunais de contas, além é claro da polícia e do Judiciário. Quinto, porque, como pontua Anna Carla Duarte Chrispim, relatórios de órgãos não-governamentais indicam que o índice de corrupção praticado por funcionários públicos no Brasil é alto no que tange aos funcionários que exercem cargos eletivos, sendo considerado baixo ou moderado no serviço público e na área de fiscalização ${ }^{415}$. Sexto, porque, como ressalta Helena Marques Junqueira, a busca de vantagens pessoais em troca da redução de tributos pelas autoridades competentes poderá ser consideravelmente minimizada pela transparência decorrente da motivação das decisões relativas à transação, bem como da divulgação de seus resultados ${ }^{416}$. Por fim, sétimo, porque não se pode olvidar que o medo em relação à transação tributária vem da patologia; essa não deve ser considerada como a regra, mas sim, como a exceção, sendo tratada como tal; caso venha a se concluir que os atuais mecanismos de controle da atividade estatal não são suficientes para coibir abusos, o ideal é que eles sejam aperfeiçoados e não que a transação tributária seja simplesmente excluída.

Em síntese, o excesso de discricionariedade atribuído à autoridade fiscal para celebrar a transação pode sem dúvida nenhuma favorecer a corrupção e a utilização da transação como instrumento político. Esses males, no entanto, sondam não somente a Administração tributária, como todos os demais órgãos do poder público. Porém, não existem dados que indiquem com precisão que haverá o uso indiscriminado desse instrumento para fins alheios àqueles que ele se propõe originalmente. Demais disso, não é demais lembrar que já existem diversos mecanismos em nosso ordenamento jurídico para prevenir o uso abusivo da transação tributária: é o caso dos instrumentos e órgãos de

\footnotetext{
${ }^{415}$ CHRISPIN, Anna Carla Duarte. Transação Tributária no Paradigma do Estado Democrático de Direito Socioeconômico Cultural: o tênue limite entre a afronta ao dever fundamental de pagar tributos e a mutação da legalidade estrita rumo a juridicidade consensual dialógica. Dissertação (Mestrado em Direito), Faculdade de Direito da Pontifícia Universidade Católica de Minas Gerais, 2009, p. 134. A esse respeito, a autora destaca, também, rebatendo as críticas efetuadas por Eurico Diniz de Santi, que a Administração tributária brasileira acata quase todos os indicadores de desempenho para a redução do risco de corrupção. Além disso, enfatiza que alguns relatórios dão conta de que empresas do ramo da construção civil e o setor bancário, além do Parlamento e do Poder Judiciário, são algumas das instituições mais corruptas para a sociedade latino-americana.

416 JUNQUEIRA, Helena Marques. Transação Tributária. Tese (Doutorado em Direito), Faculdade de Direito da Pontifícia Universidade Católica de São Paulo, 2009, p. 189-190. A esse respeito, inclusive, Hugo de Brito Machado, vai ainda mais além, ressaltando que: “[...] E até se pode sustentar que a corrupção será reduzida com a possibilidade legal de acordo, pois no âmbito da transação oficialmente realizada tudo terá de ser transparente, inclusive e especialmente as razões pelas quais a Fazenda Pública está transigindo." (MACHADO, Hugo de Brito. Transação e arbitragem no âmbito tributário. In: SARAIVA FILHO, Oswaldo Othon de Pontes; GUIMARÃES, Vasco Branco (Orgs.). Transação e Arbitragem no Direito Tributário. Belo Horizonte: Forum, 2008, p. 127).
} 
fiscalização e controle. Enfim, caso venha a se concluir que esses não são suficientes, devem eles ser aperfeiçoados e não simplesmente excluir a transação tributária.

\subsection{Algumas experiências em vigor no direito interno}

A despeito da falta de regulamentação em âmbito federal do disposto no art. 171 do CTN, alguns Estados da federação já aprovaram leis estaduais que permitem a transação em matéria tributária. Da mesma forma, não parece existir nenhum empecilho a que a transação (inclusive tributária) ocorra nos Juizados Especiais Federais. Tais leis parecem corroborar o entendimento de que o instituto da transação tributária é não somente compatível com o ordenamento jurídico brasileiro, como também desejável como instrumento de solução de controvérsias. No âmbito estadual, esse é o caso, por exemplo $^{417}$, dos Estados de Minas Gerais, de Pernambuco e de Santa Catarina, conforme se verá em detalhes a seguir.

\subsubsection{No Estado de Minas Gerais}

A transação em matéria tributária está prevista na legislação do Estado de Minas Gerais há muito tempo. Apenas 10 (dez) anos após a edição do CTN, foi promulgada a Lei estadual $\mathrm{n}^{\circ} 6.763$, de 26 de dezembro de 1975, consolidando a legislação tributária naquele Estado.

Esse normativo previu, na redação original de seu art. 217, que o Poder Executivo, por meio de decreto, que indicasse a autoridade competente, poderia autorizar a realização de transação, bem como outras formas de extinção do crédito tributário ${ }^{418}$. Tal previsão foi objeto de diversas alterações ao longo dos anos, a fim de aprimorá-la e compatibilizá-la com o ordenamento jurídico nacional.

\footnotetext{
${ }^{417}$ Ressalte-se que os Estados aqui mencionados o são a título exemplificativo e não exaustivo. Não foi efetuada uma análise da legislação tributária de todos os Estados para verificar se neles haveria a previsão de transação em matéria tributária. $\mathrm{O}$ intuito aqui foi tão somente demonstrar que alguns Estados já regulamentaram o instituto da transação em matéria tributária em suas legislações, de forma que a experiência nesses Estados possa servir de referência para o aperfeiçoamento do Projeto de Lei em discussão. Nesse sentido, frise-se que o Parecer PGFN/CAT n ${ }^{\circ}$ 2254/2009 dá conta de que também o Estado do Rio Grande do Sul, bem como os Municípios de Angra dos Reis, Belo Horizonte, Campinas e Curitiba já prevêem a possibilidade de transação em suas respectivas legislações. Essa mesma colocação é feita por Arnaldo Godoy em sua recente obra (GODOY, Arnaldo Sampaio de Moraes. Transação Tributária: introdução à justiça fiscal consensual. Belo Horizonte: Fórum, 2010, p. 60).

${ }^{418}$ Conforme a redação original do art. 217 da Lei estadual n 6.763/75: "O Poder Executivo, através de decreto que indicará a autoridade competente, poderá autorizar a realização de transação e concessão de anistia, remissão, moratória, parcelamento de débitos fiscais e ampliação de prazo de recolhimento de tributo, observados, relativamente ao Imposto sobre Operações Relativas à Circulação de Mercadorias (ICM), as condições gerais definidas em Convênio."
} 
Embora inicialmente não houvesse uma previsão específica no que tange aos pressupostos necessários para a celebração da transação em matéria tributária, nem em relação à sua abrangência, com o advento da Lei $n^{\circ}$ 13.435/99, passou-se a exigir, para a realização da transação tributária, parecer favorável emitido por uma comissão formada por servidores da Administração tributária e Procuradores da Fazenda Estadual ${ }^{419}$.

Demais disso, a Lei $\mathrm{n}^{\circ}$ 13.435/99 inicialmente previu que a transação em matéria tributária somente poderia alcançar um percentual da multa preestabelecido, conforme se tratasse de multa por descumprimento de obrigação acessória ou não. Previu, também, que a realização da transação tributária somente poderia se dar no curso de procedimento contencioso administrativo ou demanda judicial ${ }^{420}$.

Atualmente, a transação em matéria tributária no Estado de Minas Gerais encontra-se disciplinada nos arts. 217, caput e $\S 1^{\circ}$ da Lei estadual $n^{\circ} 6.763 / 75$ (com redação dada pela Lei $\left.n^{0} 13.435 / 99\right)$, bem como no art. 218 da Lei estadual no 6.763/75 (com redação dada pela Lei ${ }^{\circ} 14.999 / 03$ ), tendo sido regulamentada pelo Decreto $n^{\text {o }}$ 44.747/08, que trata dos processos e procedimentos tributários.

Em conformidade com a legislação mineira de regência, o Poder Executivo poderá delegar à autoridade fazendária a competência para realizar a transação, nos casos definidos em decreto. No entanto, deverão ser observadas as condições estabelecidas no art. 171 do CTN. Quer dizer, a transação tributária poderá ser realizada, mediante concessões mútuas, que impliquem na extinção do crédito tributário.

Note que esses dispositivos não fazem qualquer referência em relação à abrangência da transação (se aplicável somente à multa, juros, encargos ou também em relação ao tributo propriamente dito), nem se haveria necessidade de prévia oitiva do Ministério Público para sua celebração. O Decreto regulamentador, no entanto, estabeleceu que a transação somente poderia ocorrer em casos excepcionais, quando houver "matérias de alta indagação jurídica, de fato ou de direito" $"$ ".

\footnotetext{
${ }^{419}$ Posteriormente, com o advento da Lei $\mathrm{n}^{\mathrm{o}}$ 14.699/2003, a transação passou a depender não mais de um parecer elaborado por uma comissão, mas de aprovação, por resolução conjunta, do Secretário de Estado da Fazenda e do Advogado-Geral do Estado. Recentemente, porém, a Lei n ${ }^{\circ} 15.425 / 2004$ novamente alterou esse dispositivo para prever que a transação dependerá de parecer fundamentado e que este parecer deverá ser aprovado por resolução conjunta do Secretário de Estado da Fazenda e do Advogado-Geral do Estado.

${ }^{420}$ Vale destacar que a partir da Lei estadual $n^{\circ} 13.741 / 2000$, o âmbito da aplicação da transação tributária no Estado de Minas Gerais foi estendido para alcançar também os juros e demais encargos incidentes sobre a dívida. Essa lei previu também que a transação tributária somente poderia se efetivar no curso de demanda judicial e com a oitiva do Ministério Público.

${ }^{421}$ Art. 191, caput, do Decreto n ${ }^{\circ}$ 44.747/08: “A transação será realizada em casos excepcionais, no
} 
A esse respeito, é importante salientar que o legislador mineiro não definiu quais seriam as matérias consideradas de "alta indagação jurídica". Na definição das situações em que poderia ser utilizada a transação, utilizou-se um conceito jurídico indeterminado. Tal conduta deixa uma margem excessiva de discricionariedade à autoridade administrativa, que poderá eleger os casos que assim entender por bem. Isso pode, eventualmente, acarretar privilégios a determinados contribuintes em detrimento de outros que se encontrem em idêntica ou semelhante situação.

É verdade que a celebração da transação não depende exclusivamente da autorização de uma única autoridade administrativa. Esta autorização é um ato complexo, que pressupõe a manifestação de vontade de várias autoridades: primeiro, faz-se necessária a elaboração de parecer favorável emitido pela Advocacia-Geral de Estado e, tratando-se de matéria de fato, deve haver parecer técnico emitido pelas Superintendências de Fiscalização, de Tributação, e de Arrecadação e Informações Fiscais, no âmbito de suas respectivas competências; após, necessária também a aprovação deste parecer por resolução conjunta do Secretário da Fazenda e do AdvogadoGeral do Estado ${ }^{422}$. Tal complexidade é benféfica, pois limita a discricionariedade administrativa e eventuais abusos que possam ser cometidos.

Ademais, o legislador mineiro previu que as resoluções conjuntas que aprovassem os pareceres fundamentados fossem publicadas no Diário Oficial do Estado ${ }^{423}$. Este procedimento assegura a publicidade da transação e uma maior transparência em relação a seus beneficiários. Todavia, o que se publica é tão somente a resolução que aprova o parecer e autoriza a transação e não os termos e condições da transação celebrada com os particulares, que permanecem fora do alcance dos demais contribuintes.

Com efeito, para dar maior transparência, parece salutar que a resolução publicada contivesse os termos e condições da transação que se aprovou ou, alternativamente, que fossem também publicados no Diário Oficial, ou disponibilizados no sítio da Secretaria da

interesse da Fazenda Pública Estadual, mediante concessões mútuas, para extinguir litígio, quando se tratar de matéria de alta indagação jurídica, de fato ou de direito."

${ }^{422}$ Conforme art. 218, IV da Lei estadual $n^{\circ} 6.763 / 75$ (com redação dada pela Lei $n^{\circ} 14.999 / 03$ ), bem como art. 191, § único, inciso II do Decreto $\mathrm{n}^{\circ} 44.747 / 08$.

${ }^{423}$ É o caso da Resolução Conjunta no 3.574, de 30 de setembro de 2004 (MG 01.10.2004), que aprovou transação em matéria tributária com a Fiat Automóveis S/A. Disponível em: <http://www.fazenda.mg. gov.br/empresas/legislacao tributaria/resolucoes/2004/rr3574_2004.htm>. Acesso em: 12 nov. 2012. Ainda, a Resolução Conjunta $\mathrm{n}^{\circ}$ 3.970, de 14 de março de 2008 (MG 15.03.2008), que aprovou transação em matéria tributária com a Usinas Siderúrgicas de Minas Gerais S/A (USIMINAS). Disponível em: $<\mathrm{http} / / / \mathrm{www}$.fazenda.mg.gov.br/empresas/legislacao_tributaria/resolucoes/2008/rr3970_2008.htm>. Acesso em: 12 nov. 2012. 
Fazenda, os pareceres fundamentados, tanto aqueles favoráveis quanto aqueles contrários à proposta de transação. Isso, sem dúvida alguma, asseguraria uma maior transparência, inibindo abusos e permitindo um maior controle dos contribuintes em relação às transações que foram celebradas pelo governo mineiro.

\subsubsection{No Estado de Pernambuco}

Em Pernambuco, a transação tributária encontra-se prevista na Lei Complementar estadual $n^{\circ} 105$, de 20 de dezembro de 2007, que trouxe medidas para evitar e reduzir a litigiosidade no âmbito do Estado de Pernambuco ${ }^{424}$. Entre essas medidas, encontra-se justamente a autorização para que o Procurador-Geral do Estado de Pernambuco transacione, judicial ou extrajudicialmente, em matérias em que o Estado, suas autarquias ou fundações públicas seja parte ou interessado. A seção desta lei destinada à transação, frise-se, não trata única e exclusivamente da transação (em matéria tributária), mas sim da transação em relação a créditos públicos em geral.

Em conformidade com o disposto na referida lei complementar e no Decreto $\mathrm{n}^{\mathrm{o}}$ 32.549/08, que a regulamentou, para que possa haver transação, além da presença do interesse público e da conveniência administrativa, é necessária a observância de alguns requisitos, entre os quais: (a) parecer fundamentado; (b) oitiva do órgão ou entidade interessados na demanda; e (c) oitiva do conselho de programação financeira.

Além do mais, os próprios Procuradores do Estado de Pernambuco poderão também transacionar, diretamente, no curso de ações judiciais em que atuem, desde que os valores discutidos na demanda não ultrapassem o valor de 40 (quarenta) saláriosmínimos e que haja autorização do Procurador-Geral do Estado para tanto. Presentes os requisitos para a transação, será requerida a suspensão do processo.

No âmbito tributário, o legislador estadual pernambucano optou por não abrir mão do tributo nem da multa, juros e demais acréscimos porventura cobrados. Exceção a essa regra ocorre quando estiverem presentes, cumulativamente, duas condições: (a) o litígio versar sobre matéria em que a jurisprudência do STF ou dos tribunais superiores seja desfavorável à Fazenda Pública; e (b) o sujeito passivo da obrigação renunciar ao seu

\footnotetext{
${ }^{424}$ Além do instituto da transação, a Lei Complementar estadual n ${ }^{\circ}$ 105/07 prevê hipóteses de o Estado deixar de propor ações judiciais ou abrir mão de recorrer em processos que envolvam temas já pacificados no Supremo Tribunal Federal (STF) e no Superior Tribunal de Justiça (STJ) em favor do contribuinte ou quando o valor do débito for irrisório. Ademais, a referida lei trata ainda da adjudicação de bens móveis e imóveis e da compensação de créditos inscritos em Dívida Ativa com precatórios e RPV.
} 
eventual direito às verbas de sucumbência (honorários, custas e demais ônus processuais).

Note-se, ainda, que o legislador pernambucano previu também um mecanismo de controle para evitar abusos de poder e garantir maior transparência em relação aos termos e condições da transação celebrada com os particulares. Com efeito, sempre que a transação implicar obrigação pecuniária ao Estado, suas autarquias ou fundações públicas (é o caso da repetição de indébito), o pagamento por parte destes entes somente poderá se dar após publicação de extrato contendo os termos do acordo no Diário Oficial.

Não obstante o detalhamento da legislação de Pernambuco, a lei de transação pernambucana merece alguns reparos. É que os mecanismos de controle nela previstos não parecem ser suficientes. A observância ao princípio da publicidade faz com que não somente as transações que impliquem obrigação pecuniária aos entes da Administração como também aquelas que impliquem em renúncia de receitas necessitem de publicação de seu extrato no Diário Oficial. Ademais, para garantir a transparência nas relações fiscocontribuinte e maior controle por parte dos contribuintes, não basta a publicação de seu extrato, sendo recomendada a publicação dos termos e condições pactuados.

\subsubsection{No Estado de Santa Catarina}

A previsão da transação em matéria tributária em Santa Catarina não é recente. $\mathrm{O}$ Estado de Santa Catarina previu a possibilidade de transação em matéria tributária apenas alguns meses após sancionado o CTN, com a edição da Lei estadual $n^{\circ} 3.938$, de 26 de dezembro de 1966, contendo normas de legislação tributária estadual.

Entre essas normas, destaca-se o disposto no art. 82 desta Lei, que transcreveu quase que ipsis literis o disposto no art. 171 do CTN: “A lei pode facultar, nas condições que estabeleça, aos sujeitos ativo e passivo da obrigação tributária celebrar transação que, mediante concessões mútuas, importe em terminação de litígio e conseqüente extinção de crédito tributário". Acresceu, ainda, em seu parágrafo único que "A lei indicará a autoridade competente para autorizar a transação em cada caso" ${ }^{" 425}$.

Atualmente, a transação tributária no Estado de Santa Catarina está regulada pela Lei estadual $n^{\circ} 10.789$, de 3 de julho de 1998, que teve por objetivo estimular o cumprimento voluntário das obrigações tributárias pelos contribuintes. Verifica-se desse

\footnotetext{
${ }^{425}$ A única diferença em relação aos dois dispositivos consiste em que, enquanto o art. 171 do CTN falou em determinação de litígios, o art. 82 da Lei estadual $\mathrm{n}^{\circ}$ 3.938/66 utilizou a expressão terminação de litígios. Acerca dessa questão, conferir item 3.2.3 deste trabalho.
} 
normativo que a Seção $\mathrm{V}$, que trata da transação, cuidou da transação propriamente dita (art. $8^{\circ}$ ), e da transação na "modalidade" de dação em pagamento (art. $9^{\circ}$ ).

O tratamento da dação em pagamento como modalidade de transação parece equivocado. Isso porque, embora ambas extinguam o crédito tributário, são modalidades de extinção distintas, regulamentadas por diferentes incisos do art. 156 do $\mathrm{CTN}^{426}$. Tanto isso é verdade que a transação pressupõe a existência de uma controvérsia, bem como concessões mútuas das partes para a terminação daquela, na forma como estabelece o art. 171 do CTN. O mesmo não ocorre com a dação em pagamento.

Superado tal equívoco, passemos à análise dos pressupostos e condições para a realização da transação no Estado de Santa Catarina.

A Lei estadual $n^{\circ} 10.789 / 98$ previu a possibilidade do Executivo celebrar transação em matéria tributária, atribuindo tal competência ao Secretário de Estado da Fazenda e ao Procurador-Geral do Estado, no âmbito de suas respectivas atribuições legais. Previu, também, que tal competência seria indelegável ${ }^{427}$. Além disso, estabeleceu que a transação tributária somente poderá se realizar "mediante prévia e expressa autorização conferida, caso a caso, pela Assembléia Legislativa”, excepcionando desta autorização, tão somente, os créditos de valor igual ou inferior a um determinado valor ${ }^{428}$.

Como se vê, ao contrário de outros Estados, a legislação catarinense não condicionou a celebração de transação à existência de um parecer favorável, nem à oitiva prévia de nenhum outro órgão do Executivo. Isso não significa, porém, que as autoridades legitimadas a transacionar possuam ampla discricionariedade para fazê-lo. É que, conforme a legislação de regência, a celebração da transação por essas autoridades está condicionada a uma autorização prévia e específica do Legislativo.

Verifica-se, pois, que os Estados de Minas Gerais, Pernambuco e Santa Catarina já editaram e regulamentarem normas estaduais prevendo a possibilidade de transação em matéria tributária em relação aos tributos de sua competência. Essa iniciativa coaduna-se com o andar do Direito Tributário contemporâneo, que privilegia uma maior participação

\footnotetext{
${ }^{426}$ Enquanto a transação está prevista no inciso III do art. 156 do CTN, a dação em pagamento encontra previsão no inciso XI do mesmo artigo. Note, todavia, que este último inciso somente foi introduzido com o advento da $\mathrm{LC}^{\circ}{ }^{\circ} 104 / 01$. Com efeito, antes disso, era muito comum a dação em pagamento ser entendida como forma de transação, para que houvesse um embasamento para sua realização. Hoje, porém, com o advento desta nova modalidade de extinção, com carectéristicas próprias, este não parece ser mais o caso.

${ }^{427}$ Art. $8^{\mathrm{o}}, \S 1^{\mathrm{o}}$ e $\S 2^{\circ}$, da Lei Estadual n ${ }^{\mathrm{o}} 10.789 / 98$.

${ }^{428}$ Art. $8^{\circ}$, caput e $\S 3^{\circ}$, da Lei Estadual $n^{\circ} 10.789 / 98$. De acordo com esse dispositivo, essa autorização somente seria necessária para os créditos de valor superior a 50.000 (cinquenta mil) UFIRs.
} 
da sociedade na tributação, a eficiência administrativa e o papel não somente de coletor de tributos, mas também de facilitador das relações por parte do fissco ${ }^{429}$.

\subsubsection{Nos Juizados Especiais Federais (Lei $\left.\mathrm{n}^{0} \mathbf{1 0 . 2 5 9} / 2001\right)$}

Conforme já analisado, a transação em matéria tributária pressupõe lei autorizadora que permita sua realização, bem como indique a autoridade com poderes para tanto, a teor do disposto no art. 171do CTN. Alguns Estados já editaram leis nesse sentido prevendo a possibilidade de transação em matéria tributária e a autoridade competente para autorizá-la, em relação aos tributos de suas respectivas competências.

Em âmbito federal, apesar de ainda se encontrar em discussão, no Congresso Nacional, o Projeto de Lei Geral de Transação em matéria tributária ${ }^{430}$, há quem defenda que a transação tributária já encontraria respaldo no ordenamento brasileiro. Essa previsão encontrar-se-ia na Lei ${ }^{\circ} 10.259 / 2001$, que instituiu os denominados Juizados Especiais Federais (JEFs), bem como definiu o âmbito de sua competência ${ }^{431}$.

Em conformidade com o referido normativo, compete ao JEF processar e julgar as causas de competência da Justiça Federal, cujo valor não exceda sessenta salários mínimos (art. $3^{\circ}$, caput), desde que não se encontrem expressamente excluídas. Encontram-se excluídos da competência do JEF os mandados de segurança e as execuções fiscais (art. $\left.3^{\circ}, \S 1^{\circ}, I\right)$. Estão igualmente excluídas as ações cujo objeto seja a anulação ou cancelamento de atos administrativos federais, salvo aqueles de natureza previdenciária e os lançamentos fiscais (art. $3^{\circ}, \S 1^{\mathrm{o}}$, III).

Fazendo uma interpretação a contrario sensu do referido dispositivo, pode-se dizer que o JEF tem competência para processar e julgar algumas ações de natureza tributária. É o caso, por exemplo, das ações de repetição de indébito, das ações declaratórias de inexistência de relação jurídica tributária e, inclusive, das ações anulatórias de lançamento tributário, além de eventuais outras ${ }^{432}$. Isto, desde que, evidentemente, seu valor não

${ }^{429}$ GODOY, Arnaldo Sampaio de Moraes. A Transação Tributária em Pernambuco. Disponível em: $<\mathrm{http} / /$ cfc.jusbrasil.com.br/noticias/318311/a-transacao-tributaria-em-pernambuco $>$. Acesso em: 14 nov. 2012.

${ }^{430}$ A esse respeito, conferir capítulo IV deste trabalho.

431 Nesse sentido é o posicionamento de Jefferson Carús Guedes. (GUEDES, Jefferson Carús. Transigibilidade de interesses públicos: prevenção e abreviação de demandas da Fazenda Pública. In: GUEDES, Jefferson Carús et al. (Coords.). Advocacia de Estado: questões institucionais para a construção de um Estado de justiça. Belo Horizonte: Fórum, 2009, p. 268).

432 MACHADO, Hugo de Brito. Transação e arbitragem no âmbito tributário. In: SARAIVA FILHO, Oswaldo Othon de Pontes; GUIMARÃES, Vasco Branco (Orgs.). Transação e Arbitragem no Direito 
ultrapasse sessenta salários mínimos.

Resta saber, no entanto, se a União poderia transacionar no bojo dessas ações.

A esse respeito, frise-se que a própria Lei $\mathrm{n}^{0} 10.259 / 2001$ previu que os representantes da União, autarquias, fundações e empresas públicas "ficam autorizados a conciliar, transigir ou desistir" nos processos de competência dos Juizados Especiais (art. $10, \S$ único). Esse normativo não impôs quaisquer condições para a realização da transação por seus representantes judiciais. Tampouco restringiu sua aplicação a matérias não tributárias, razão pela qual se presume ser aplicável também a discussões tributárias.

Para regulamentar esta lei, foi editado o Decreto $n^{\circ} 4.250 / 2002$. Esta norma atribuiu competência ao Advogado-Geral da União para fixar diretrizes básicas para as carreiras da advocacia pública federal. Entre essas diretrizes, encontram-se aquelas relativas à conciliação, transação e dispensa de interposição de recursos pelos seus respectivos membros (art. $\left.2^{\circ}\right)^{433}$. Não obstante, resguardou-se a possibilidade de edição de instruções específicas por cada um dos chefes máximos de algumas instituições, inclusive por parte do Procurador-Geral da Fazenda Nacional (art. $2^{\circ}, \S$ único).

Com fundamento nesse decreto, a Advocacia-Geral da União editou a Portaria $n^{\circ}$ $505 / 2002$. Esta portaria trouxe inúmeras condições para que os advogados públicos federais pudessem efetuar transações no âmbito dos Juizados Especiais Federais. Atualmente a matéria encontra-se regulada pela Portaria AGU n ${ }^{0}$ 107/2007. De acordo com esse normativo, a transação somente poderá se realizar quando houver erro administrativo ou quando inexistir controvérsia quanto ao fato ou ao direito aplicável. Além disso, não podem ser realizadas transações quando houver súmula da AGU, parecer aprovado na forma da $\mathrm{LC} \mathrm{n}^{\circ} 73 / 93$ ou orientação interna da AGU contrária à pretensão ${ }^{434}$.

Considerando que, nos termos da Portaria AGU no 107/2007, os advogados públicos federais somente poderiam transacionar quando existisse erro administrativo reconhecido ou inexistisse controvérsia de fato e de direito sobre a matéria, Anna Carla

Tributário. Belo Horizonte: Forum, 2008, p. 119.

${ }^{433}$ Art. $2^{\circ}$ do Decreto $n^{\circ}$ 4.250/2002: "Compete ao Advogado-Geral da União expedir instruções referentes à atuação da Advocacia Geral da União e dos órgãos jurídicos das autarquias e fundações nas causas de competência dos Juizados Especiais Federais, bem como fixar as diretrizes básicas para conciliação, transação, desistência do pedido e do recurso, se interposto.

$\S 1^{\circ}$ Respeitadas as instruções e diretrizes fixadas pelo Advogado-Geral da União, os Procuradores-Gerais da União, da Fazenda Nacional e do Instituto Nacional do Seguro Social poderão expedir instruções específicas para as respectivas procuradorias." (grifo nosso).

${ }^{434}$ CHIMENTI, Ricardo Cunha. Teoria e Prática dos Juizados Especiais Cíveis Estaduais e Federais. São Paulo: Saraiva, 2012, p. 53. 
Duarte Chrispin defende que a transação de que tratou a referida portaria não seria a transação do art. 171 do CTN. Isso porque a transação prevista no CTN pressupõe a existência de controvérsia para sua realização enquanto aquela pressupõe sua inexistência. E prossegue, indo mais além, para dizer que a referida portaria seria uma mera declaração de intenção de não procrastinação judicial que não afetaria a matéria tributária ${ }^{435}$.

De fato, a Portaria AGU n 107/2007 teve, sem dúvida nenhuma, por objetivo reduzir a litigiosidade no âmbito dos Juizados Especiais Federais. Porém, parece equivocada a idéia de que esta não tenha impacto na esfera tributária. Aparentemente, a menção à inexistência de controvérsia de fato e de direito como pressuposto para realização da transação prevista na Lei $n^{\circ}$ 10.259/2001 teve como propósito abarcar aquelas demandas de grande volume, repetitivas e pacificadas nos tribunais superiores. E, nesse aspecto não só podem como, de fato, envolvem questões tributárias.

Nesse sentido, vale ressaltar serem inúmeras as causas no JEF em que se discute alguma matéria tributária que já se encontra pacificada na jurisprudência das cortes superiores. A título de exemplo, pode-se citar a discussão acerca da incidência de IR sobre férias indenizadas. Apesar de haver dispensa de interposição de recursos em relação à matéria de fundo, muitas vezes, as discussões judiciais envolvendo essas questões já pacificadas se prolongam no JEF, chegando inclusive às Turmas Recursais e, por vezes, até ao STF, por meio de Recurso Extraordinário, por questões de ordem puramente processual (e.g. ausência de documentos comprobatórios do direito, nulidade de sentença ilíquida, violação ao contraditório e ampla defesa). A transação nessas demandas, embora pouco utilizada, tem utilidade prática, pois evita o prolongamento da discussão judicial em troca da redução do valor devido pela Fazenda Nacional.

Em conclusão, a transação no âmbito do JEF encontra-se prevista na Lei $n^{\circ}$ 10.259/2001, já tendo, inclusive sido regulamentada pela Advocacia-Geral da União. Embora esses normativos não se refiram exclusivamente à transação em matéria tributária, pode-lhe ser igualmente aplicável, na medida em que os Juizados Especiais Federais têm competência para julgar questões tributárias; e tanto o dispositivo da lei

\footnotetext{
435 Segundo a autora: "É claro, que diante do exposto, não se admite que o ato regulatório da AGU esteja dispondo propriamente da transação em matéria tributária. Ele se propõe mais a ser uma declaração de intenção da não procrastinação processual por parte da União que, embora possa parecer muito nobre, na realidade não afeta matéria tributária, sendo inócuo neste assunto pelos motivos já expostos". (CHRISPIN, Anna Carla Duarte. Transação Tributária no Paradigma do Estado Democrático de Direito Socioeconômico Cultural: o tênue limite entre a afronta ao dever fundamental de pagar tributos e a mutação da legalidade estrita rumo a juridicidade consensual dialógica. Dissertação (Mestrado em Direito), Faculdade de Direito da Pontifícia Universidade Católica de Minas Gerais, 2009, p. 96-97).
} 
quanto sua regulamentação não fazem qualquer restrição ao objeto da transação ser matéria tributária. Por fim, frise-se que, possivelmente, em razão das diversas questões envolvendo à possibilidade de transação no âmbito tributário, na prática, a utilização da transação em matéria tributária no JEF tem sido bastante comedida ${ }^{436}$.

${ }^{436}$ GUEDES, Jefferson Carús. Transigibilidade de interesses públicos: prevenção e abreviação de demandas da Fazenda Pública. In: GUEDES, Jefferson Carús et al. (Coords.). Advocacia de Estado: questões institucionais para a construção de um Estado de justiça. Belo Horizonte: Fórum, 2009, p. 268. Demais disso, vale a pena ressaltar que a PGFN não vem se utilizando da transação em matéria tributária no âmbito dos JEF/SP. 


\section{CAPÍtulo IV - ANÁlise do PROJETO DE LEI GERAL DE TRANSAÇÃO TRIBUTÁRIA}

Depois de analisadas as transformações no Direito Tributário, que preconizam pela mudança de paradigmas da relação entre fisco e contribuintes (Capítulo I), bem como superado o dogma da impossibilidade de transação em matéria de Direito Público pela Administração (Capítulo II) e, finalmente, examinadas algumas das principais questões relacionadas à transação em matéria tributária diante das diretrizes do ordenamento jurídico brasileiro (Capítulo III), seguem-se considerações acerca das particularidades do Projeto de Lei Geral de Transação em matéria tributária (PL n $\left.{ }^{0} 5.082 / 2009\right)^{437}$.

Os aspectos jurídicos examinados ao longo do trabalho são a base para a análise das disposições do Projeto de Lei Geral de Transação em matéria tributária (PL n ${ }^{\circ}$ 5.082/2009) e para um exame crítico de vários de seus dispositivos. A intenção é a de demonstrar, a partir de um exemplo concreto de proposta de regulamentação da transação tributária, como essa potencial norma se integra com algumas das demais normas do ordenamento jurídico brasileiro. Utilizando o exemplo particular desse projeto, quer-se examinar como a transação tributária possivelmente ocorrerá em âmbito federal.

Conforme antecipado, tramita no Congresso Nacional, um Projeto de Lei Geral de Transação em matéria tributária (PL n ${ }^{\circ}$ 5.082/2009). Esse projeto, senão o único sobre o assunto, certamente o de maior repercussão no meio acadêmico, insere-se no contexto do II Pacto Republicano de Estado e tem por base o anteprojeto elaborado sob orientação do Procurador-Geral da Fazenda Nacional à época. Após sofrer várias alterações em virtude de comentários e críticas da comunidade jurídica no decorrer de sua elaboração, o Projeto foi encaminhado à Câmara dos Deputados onde se encontra atualmente ${ }^{438}$.

Com efeito, serão efetuados, nesse capítulo, alguns comentários pontuais sobre o Projeto de Lei Geral de Transação em matéria tributária, em especial para: tecer considerações sobre a lei que se pretende e o contexto de sua elaboração (item 4.1); fazer

\footnotetext{
${ }^{437}$ Toda e qualquer referência feita neste capítulo a "Projeto de Lei" ou simplesmente a "PL" diz respeito, por óbvio, ao PL n $\mathrm{n}^{\circ} 5.082 / 2009$, também denominado Projeto de Lei Geral de Transação em matéria tributária.

${ }^{438}$ De acordo com informações obtidas junto ao sítio da Câmara dos Deputados. Disponível em: $<$ http://www.camara.gov.br>. Acesso em: 15 jan. 2013. O último andamento que consta é uma manifestação do Presidente da Câmara à época, sr. Michel Temer, deferindo requerimento para que o PL em questão seja submetido à audência da Comissão de Constituição e Justiça e de Cidadania daquela Casa legislativa (em 04 maio de 2010).
} 
uma análise das suas disposições e do regime geral da transação (item 4.2); e detalhar as diversas modalidades de transação e suas particularidades (item 4.3). Essa primeira etapa tem característica notadamente descritiva e serve para melhor compreender as disposições do projeto, não se furtando, todavia, a efetuar uma análise crítica das disposições quando estas forem incompreensíveis ou inconsistentes com as demais disposições do PL ou com as demais normas do ordenamento jurídico brasileiro.

Finalmente, serão também examinados nesse capítulo: os efeitos nas diferentes etapas do procedimento transacional (item 4.4); as hipóteses de revogação, nulidade e revisão da transação e suas consequências (item 4.5); algumas críticas em relação ao disposto no PL (item 4.6); e, por derradeiro, serão efetuadas algumas considerações finais em relação ao PL e seus dispositivos (item 4.7). Nessa etapa, busca-se efetuar, sobretudo, uma análise crítica e científica das disposições do PL em questão.

\subsection{Considerações iniciais sobre o Projeto de Lei $n^{0} 5.082 / 2009$}

O Poder Executivo optou por encaminhar um projeto de lei ordinária para regulamentar a transação tributária em âmbito federal. Tal opção seria, em princípio, discutível, na medida em que o Projeto de Lei em questão contém dispositivos que podem ser considerados normas gerais em matéria de legislação tributária, sujeitos à lei complementar, por força do disposto no art. 146, III, "b”, da $\mathrm{CF} / 88^{439}$. Por essa razão, entendeu-se por bem encaminhar também, paralelamente, um Projeto de Lei complementar para alteração do CTN. Trata-se do PLC no 469/2009440.

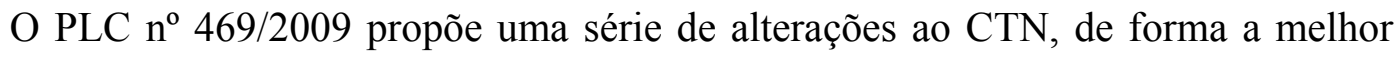
compatibilizá-lo com instituto da transação tributária e evitar algumas das questões colocadas pela doutrina em relação à sua implementação. Comparando-se a redação proposta com a atual redação do art. 171, do CTN, verifica-se que a nova redação afasta-

\footnotetext{
${ }^{439}$ MACHADO, Hugo de Brito. Transação e arbitragem no âmbito tributário. In: SARAIVA FILHO, Oswaldo Othon de Pontes; GUIMARÃES, Vasco Branco (Orgs.). Transação e Arbitragem no Direito Tributário. Belo Horizonte: Forum, 2008, p. 131. É o caso, por exemplo, do dispositivo que prevê a interrupção da prescrição quando do descumprimento das obrigações assumidas no termo de transação (art. 13, I, do PL $\mathrm{n}^{\circ} 5.082 / 2009$ ), bem como daquele que prevê a suspensão da exigibilidade do crédito e a possibilidade de obtenção de certidão de regularidade fiscal quando admitida a proposta de transação (art. 20, do PL n ${ }^{\circ} 5.082 / 2009$ ).

${ }^{440}$ De acordo com informações obtidas junto ao sítio da Câmara dos Deputados, o último andamento que consta é um parecer apresentado pelo relator da Comissão de Finanças e Tributação daquele órgão, Deputado José Guimarães (PT-CE), propondo algumas mudanças redacionais com base no Substitutivo aprovado pela Comissão de Desenvolvimento Econômico, Indústria e Comércio (em 11 dez. 2012). Disponível em: <http://www.camara.gov.br>. Acesso em: 24 jan. 2013.
} 
se da noção clássica de transação, em especial, porque: (a) faz expressa menção a que a lei que faculta a celebração da transação pode ser geral ou específica; (b) retira o pressuposto de concessões mútuas para a realização da transação tributária; e (c) substitui a expressão determinação do litígio, pela expressão composição de conflitos ou litígio ${ }^{441}$.

Note que o Projeto de Lei Geral de Transação em matéria tributária, juntamente com outros a ele apensados ${ }^{442}$, busca assegurar uma maior celeridade e eficiência à atuação da Administração tributária. Esse projeto é resultado da mudança completa de paradigma, tendo como escopo a constituição de uma nova relação entre físco e contribuinte, consubstanciada num diálogo aberto entre ambos ${ }^{443}$. Se aprovado, permitirá que o contribuinte tenha uma participação mais efetiva na aplicação da legislação tributária e na resolução de conflitos tributários entre fisco e contribuintes.

Foi elaborado tendo em conta não somente a experiência internacional, como também a legislação nacional sobre o assunto, em especial, os dispositivos que tratam da matéria no Código Tributário Nacional $(\mathrm{CTN})^{444}$. Ademais, tal Projeto de Lei seria reflexo da ineficácia da execução fiscal e do reduzido percentual da Dívida Ativa arrecadado por meio desse instrumento de cobrança do crédito tributário.

Em princípio, a adoção de uma lei desse gênero traria vantagens para ambas as partes $^{445}$ : (a) para o Fazenda Nacional, a rápida realização do crédito tributário sem os custos do processo judicial a ele inerentes; (b) para o contribuinte, além da redução dos custos de advogados e da insegurança jurídica relacionados a longas discussões, a eliminação de eventuais distorções de mercado com impactos na livre concorrência, resultante do não pagamento de tributos mediante discussão administrativa ou judicial ${ }^{446}$.

\footnotetext{
${ }^{441}$ GODOY, Arnaldo Sampaio de Moraes. Transação Tributária: introdução à justiça fiscal consensual. Belo Horizonte: Fórum, 2010, p. 139.

${ }^{442}$ É o caso do projeto de lei referente aos mecanismos de cobrança dos créditos inscritos na dívida ativa da União (PL n ${ }^{0} 5.081 / 2009$ ), além do projeto de lei de execução fiscal administrativa (PL $n^{0}{ }^{5.080 / 2009}$ ).

443 TORRES, Ricardo Lobo. Transação, conciliação e processo tributário administrativo equitativo. In: SARAIVA FILHO, Oswaldo Othon de Pontes; GUIMARÃES, Vasco Branco (Orgs.). Transação e Arbitragem no Direito Tributário. Belo Horizonte: Forum, 2008, p. 89-110.

${ }^{444}$ MARTINS FILHO, Luiz Dias; ADAMS, Luís Inácio Lucena. A transação no Código Tributário nacional (CTN) e as novas propostas normativas de leis autorizadoras. In: SARAIVA FILHO, Oswaldo Othon de Pontes; GUIMARÃES, Vasco Branco (Orgs.). Transação e Arbitragem no Direito Tributário. Belo Horizonte: Forum, 2008, p. 37.

445 Conforme EM Interministerial $\mathrm{n}^{\circ}$ 00204/2008 - MF, de 10.12 de 2008, que fundamentou o encaminhamento da Minuta do Anteprojeto de Lei Geral de Transação em Matéria Tributária, quando de seu encaminhamento ao Presidente da República.

${ }^{446}$ Sobre o impacto da sonegação na livre concorrência, conferir ROTHMANN, Gerd Willi. Tributação, Sonegação e Livre Concorrência. In: FERRAZ, Roberto (Coord). Princípios e limites da tributação 2 - Os princípios da ordem econômica e a tributação. São Paulo: Quartier Latin, 2009, p. 331 et seq.
} 
Efetuadas algumas considerações iniciais em relação ao PL de transação tributária, serão analisadas a seguir algumas de suas disposições gerais, bem como o regime geral de transação contemplado no referido projeto.

\subsection{Disposições gerais do Projeto de Lei $\mathrm{n}^{0}$ 5.082/2009}

Conforme se observa da sua redação, trata-se de Projeto de Lei aplicável tão somente à União, em relação aos tributos de sua competência. Prevê as condições e os procedimentos para a celebração da transação em matéria tributária a serem observados pelos órgãos que compõem a Administração tributária federal: Secretaria da Receita Federal do Brasil e Procuradoria-Geral da Fazenda Nacional (art. $1^{\circ}$, caput).

O PL dispôs que a transação tributária é uma faculdade da Fazenda Nacional, que poderá realizá-la ou não em conformidade com seu juízo de conveniência e oportunidade $^{447}$. Tal decisão configura-se ato discricionário da Administração. Isso não se confunde, entretanto, com arbitrariedade. Ao decidir por transacionar (ou não), as autoridades competentes deverão sempre ter em mente o interesse público (art. $1^{\circ}, \S$ único) e não eventuais interesses pessoais.

Além do mais, sua redação atual parece ter seguido o entendimento doutrinário prevalecente, no sentido de que somente seria cabível em nosso ordenamento a transação tributária terminativa ${ }^{448}$, ainda que tal pressuposto tenha sido atenuado por força das alterações propostas ao art. 171 do CTN pelo PLC no 469/2009. Isso porque, a nova redação prevê que a transação importará em composição de conflitos ou litígio. Seguindo essa linha, o Projeto de Lei Geral de transação previu expressamente que a transação tributária importará em composição de conflitos ou terminação de litígios (art. $1^{\mathrm{o}}$, caput), afastando, ao que parece, a possibilidade da transação preventiva. Tal conclusão decorre da análise das disposições do PL e do fato de que, mesmo com as alterações sugeridas no PLC $n^{\circ} 469 / 2009$, a transação continua prevista entre as hipóteses de extinção do crédito tributário, o que leva a crer a necessidade de constituição do crédito pelo lançamento para tanto. No entanto, reconhe-se que a questão é controvertida, sobretudo em razão da ambiguidade da expressão composição de conflitos constante em ambos os projetos ${ }^{449}$.

\footnotetext{
447 Nesse sentido, ressalte-se o teor do art. $1^{\circ} \S$ único do PL n ${ }^{\circ} 5.082 / 2009$ : "Em qualquer das modalidades de transação de que trata esta Lei, a Fazenda Nacional poderá $[\ldots]^{\prime}$ "

${ }^{448}$ A esse respeito, conferir item 3.2.3 deste trabalho.

${ }^{449}$ Em sentido contrário, de que a expressão composição de conflitos permitiria a transação preventiva, é o posicionamento de Arnaldo Sampaio Godoy, manifestado quando do evento "Soluções Alternativas de Resolução de Conflitos: Arbitragem em Direito Tributário", realizado pela EMAG/TRF-3 ${ }^{\text {a }}$ Região entre os
} 
O PL dispôs, ainda, que a transação tributária deverá observar os princípios estabelecidos no art. 37, caput da CF/88, a saber: legalidade, impessoalidade, moralidade, publicidade e eficiência, além daqueles previstos no art. $2^{\circ}$, da Lei $n^{\circ} 9.784 / 99$, que inclui a finalidade, a motivação, a razoabilidade, a proporcionalidade, o contraditório, a segurança jurídica e o interesse público $\left(\operatorname{art} .2^{\circ}\right.$ ). A esse respeito, parece ter razão Vittorio Cassone, segundo o qual a menção expressa a esses dispositivos seria desnecessária, porém salutar, na medida em que evita eventuais dúvidas ${ }^{450}$.

Como a transação pressupõe ampla cooperação das partes envolvidas, o PL previu também os deveres de veracidade, lealdade, boa-fé, confiança e colaboração das partes, cabendo-lhes prestar todas as informações que lhes forem solicitadas para $o$ esclarecimento da questão objeto da transação (art. $2^{\circ}, \S 2^{\circ}$ ). Previu expressamente, também, que a Fazenda Nacional poderá ter acesso aos livros e documentos necessários ao procedimento de transação (art. 10). Entretanto, para evitar o tradicional receio do contribuinte em fornecer tais informações, ressalvou que, se eventualmente não se chegar à solução do litígio, os dados e informações prestados por uma das partes não poderão ser utilizados nem opostos em relação à outra (art. $3^{\circ}$, caput), salvo quando a lei determinar a obrigatoriedade de representação fiscal para fins penais e quando a informação prestada for objeto de declaração ou apresentação obrigatória (art. $3^{\circ}, \S$ único, I e II) ${ }^{451}$.

O PL traz ainda um órgão técnico especializado que terá competência para analisar e deliberar sobre os pedidos de transação, autorizando-os ou não (art. 47, caput): a Câmara-Geral de Transação e Conciliação da Fazenda Nacional (CGTC). A grande vantagem da criação de tal órgão é que esse teria maior aptidão e conhecimento técnico

dias 20 e 21 de junho de 2011. Esta, todavia, não parece ser a interpretação mais adequada a nosso ver. Ao menos na conformação atual de nosso sistema tributário. Isso porque a transação tributária em nosso ordenamento jurídico (mesmo após as alterações sugeridas no PLC n ${ }^{\circ}$ 469/2009) encontra-se entre as hipóteses de extinção do crédito tributário, o que faz pressupor a constituição deste pelo lançamento. De qualquer forma, parece adequado que se esclareça a amplitude do termo conflito contido em ambos os projetos de lei, seja para permitir a transação preventiva, seja para proibí-la. A esse repseito, frise-se ter sido apresentada a EMC no 11/2009 CTASP, de autoria do Deputado Sebastião Bala Rocha, que propõe a supressão do termo conflito, na medida em que ele dá margem à dúvida quanto à possibilidade de transação anteriormente à constituição do próprio crédito.

${ }^{450}$ CASSONE, Vitório. Transação, conciliação e arbitragem no âmbito tributário: confronto entre os princípios constitucionais aplicáveis. In: SARAIVA FILHO, Oswaldo Othon de Pontes; GUIMARÃES, Vasco Branco (Orgs.). Transação e Arbitragem no Direito Tributário. Belo Horizonte: Forum, 2008, p. 238. 451 A inoponibilidade das informações prestadas por uma parte em relação à outra na hipótese de não conclusão da transação é uma proteção relativa, sobretudo por parte do contribuinte. É que, nada impede que, posteriormente, o fisco efetue um procedimento de fiscalização para obter as informações que lhe foram fornecidas pelo contribuinte, mas que não podem ser utilizadas por força dessa vedação. Desta forma, assim como na consulta, a não conclusão da transação colocará o contribuinte numa posição vulnerável perante o fisco, aumentando o risco de uma fiscalização pontual. Sobre a consulta, conferir item 1.3.2.1 deste trabalho. 
para lidar com a complexa legislação tributária brasileira ${ }^{452}$. Segundo o projeto, a CGTC terá competência também para regulamentar a transação tributária, notadamente em relação aos requisitos, forma e parâmetros a serem observados (art. $4^{\circ}$, caput), bem como autorizar previamente as transações que poderão ser formalizadas por procuradores, inclusive no âmbito do JEF (art. $4^{\circ}, \S 2^{\circ}$ ).

Por fim, cabe salientar que a versão final do Projeto de Lei Geral de Transação, atualmente em discussão na Câmara dos Deputados, não contemplou a transação com arbitragem entre suas modalidades. A arbitragem em matéria tributária, aplicável, segundo o anteprojeto, quando existissem dúvidas em relação a questões tributárias entre físco e contribuinte, acabou por ser excluída do PL, aparentemente em razão das controvérsias existentes em relação à sua abrangência ${ }^{453}$. Isso não significa dizer que, no futuro, não possa ser introduzida também a arbitragem no Direito Tributário pátrio; até porque, esta modalidade de solução de conflitos já se encontra prevista no PLC $\mathrm{n}^{\mathrm{o}}$ 469/2009, que introduz o Art. 171-A, com o seguinte teor: "A lei poderá adotar a arbitragem para a solução de conflito ou litígio, cujo laudo arbitral será vinculante."

Feitas algumas considerações básicas acerca das disposições e do regime geral da transação tributária, será analisado a seguir, em detalhes, como se dá o seu procedimento (item 4.2.1), bem como qual a abrangência da transação prevista no PL (item 4.2.2).

\subsubsection{Procedimento da transação tributária}

O procedimento de transação pode ser dividido em três etapas principais: (a) apresentação da proposta de transação; (b) admissão da proposta de transação pela autoridade competente; e (c) solução do litígio e celebração do respectivo termo de transação fiscal pelas partes envolvidas.

O procedimento inicia-se com a apresentação da proposta de transação que se dá normalmente pelo sujeito passivo da obrigação tributária. A proposta poderá ser apresentada uma única vez, o que se definirá pela matéria objeto do litígio (art. 16, §

\footnotetext{
${ }^{452}$ MARTINS FILHO, Luiz Dias; ADAMS, Luís Inácio Lucena. A transação no Código Tributário nacional (CTN) e as novas propostas normativas de leis autorizadoras. In: SARAIVA FILHO, Oswaldo Othon de Pontes; GUIMARÃES, Vasco Branco (Orgs.). Transação e Arbitragem no Direito Tributário. Belo Horizonte: Forum, 2008, p. 38.

${ }^{453}$ CARVALHO, Rubens Miranda de. Transação Tributária, Arbitragem e outras formas convencionadas de solução de lides tributárias. São Paulo: Juarez de Oliveira, 2008, p. 202. De acordo com o autor, uma das principais críticas em relação à arbitragem na forma como se encontrava no anteprojeto era se ela poderia versar somente sobre matéria de fato, ou também sobre questões de direito.
} 
único). Deverá será instruída com algumas informações imprescindíveis, tais como: a qualificação do sujeito passivo, os elementos necessários à compreensão do conflito e as concessões que pretende realizar para extinguir o litígio (art. 18). Deve observar as disposições legais e eventual regulamentação pela CGTC (art. 16, caput), em especial, quanto aos requisitos, forma e parâmetros a serem observados (art. $4^{\circ}$, caput).

Uma vez apresentada a proposta de transação, que deverá ser protocolizada na correspondente unidade administrativa (art. 19, caput), esta será encaminhada para a autoridade competente, assim designada por resolução da CGTC. A autoridade competente poderá admitir ou recusar a proposta, bem como aceitar ou não as concessões apresentadas pelo sujeito passivo. Poderá também exigir do sujeito passivo a retificação ou a complementação da sua proposta ou da documentação que a acompanha. A emenda será considerada como nova apresentação de proposta (art. 19, § $3^{\circ}$, II).

A admissão da proposta de transação poderá se dar de maneira expressa ou tácita. Na ausência de manifestação expressa, será considerada admitida a proposta de transação no sexagésimo dia subsequente a sua recepção (art. 19, $\S 2^{\circ}$ ), salvo hipóteses específicas (art. 19, $\S 3^{\circ}$ ). Admitida a proposta, poderá a autoridade competente subordinar o prosseguimento da transação a algumas condições, em especial: (a) à exigência de prévia assinatura de termo de ajustamento de conduta; e/ou (b) à substituição ou ao efeito de solidariedade do administrador inidôneo (art. 8). A admissão ou recusa da proposta deverá ser motivada (art. 19, § $4^{\circ}$ ). Enfim, apesar da inexistência de disposição expressa no PL prevendo a possibilidade de recurso na hipótese de inadmissão da proposta, parece ser possível a aplicação subsidiária do art. 56 da Lei nº 9.784/99.

Importa salientar que existe a possibilidade de criação de Câmaras de Conciliação e Transação (CCT). Também há a possibilidade de delegação de vários atos aos Procuradores da Fazenda Nacional ou Auditores da Receita Federal do Brasil. Estes poderão: (a) apreciar e deliberar quanto à admissibilidade da proposta de transação; (b) notificar o sujeito passivo para apresentar informações ou documentos faltantes; e (c) expedir notificações ou efetuar requisições aos órgãos da Administração Pública, bem como aos interessados no procedimento de transação (art. $48, \S 1^{\circ}$ ).

Admitida a proposta de transação, as partes terão o prazo máximo de cento e oitenta dias para alcançar a solução do litígio e celebração do respectivo termo de transação (art. 21, caput). Este prazo poderá ser prorrogado por mais cento e oitenta dias 
mediante decisão motivada (art. $21, \S 1^{\circ}$ ). Findo este, o crédito tributário, que se encontrava suspenso, tornar-se-á novamente exigível em seu valor originário, permitindo o prosseguimento da cobrança (art. $21, \S 2^{\circ} \mathrm{c} / \mathrm{c}$ art. 14, caput $)^{454}$. A fixação de um prazo máximo para a conclusão da transação parece justificável dada a sua finalidade, que é assegurar maior celeridade e eficiência deste meio de solução controvérsias ${ }^{455}$.

Conforme já antecipado, um dos pressupostos para a celebração da transação é a observância ao interesse público (art. $1^{\circ}, \S$ único). Demais disso, figura-se ainda como condição para realização da transação que o sujeito passivo comprove que tenha cumprido todas as obrigações tributárias acessórias, mesmo que essas não tenham relação com o objeto da transação (art. 17). Finalmente, outra condição que se deduz do texto consiste em que o histórico fiscal do sujeito passivo, a forma de cumprimento de suas obrigações tributárias, a adoção de critérios de boa governança, bem como sua situação econômica não sejam desfavoráveis (art. $4^{\mathrm{o}}, \S 1^{\mathrm{o}} \mathrm{c} / \mathrm{c}$ art. $\left.20, \S 2^{\circ}\right)$.

A proposta será examinada pela autoridade competente designada por resolução da CGTC e encaminhada a esta com proposta de aprovação, modificação ou rejeição (art. 23, caput). Normalmente, compete à CGTC decidir pela aprovação ou rejeição da proposta de transação, por meio de decisão motivada, que conterá uma série de requisitos, entre os quais, o resumo do conflito, o montante do crédito e as condições do acordo (art. 47). Entretanto, dependendo do valor envolvido, haverá necessidade também de autorização expressa, mediante parecer fundamentado, de outras autoridades: (a) para valores superiores a R\$ 1 milhão e inferiores a R\$ 10 milhões: do Procurador-Geral da Fazenda Nacional; e (b) para valores superiores a R\$ 10 milhões: deste com a anuência do Ministro de Estado da Fazenda (art. $4^{\circ}, \S 3^{\circ}$, I e II).

Autorizada a proposta de transação pela CGTC e, sendo o caso, pelo ProcuradorGeral da Fazenda Nacional, com anuência do Ministro da Fazenda, será lavrado termo de transação (art. 23, $\S 1^{\circ}$ ). Este deverá conter diversos requisitos, entre os quais: a qualificação das partes, a referência à decisão que autorizou a transação, a especificação das obrigações ajustadas, as cláusulas do acordo (condições econômicas consideradas, responsabilidades por eventual descumprimento, renúncia aos direitos ou interesses relativos ao objeto da transação e fixação do valor devido e do montante da renúncia, se

\footnotetext{
${ }^{454}$ A esse respeito, conferir conferir item 4.4.2 deste trabalho.

455 JUNQUEIRA, Helena Marques. Transação Tributária. Tese (Doutorado em Direito), Faculdade de Direito da Pontifícia Universidade Católica de São Paulo, 2009, p. 200.
} 
houver), além da data, local e assinatura das partes (art. 24). Poderão ser designados Procuradores ou Auditores para celebração do respectivo termo (art. 48, § 1º, V).

Finalmente, a celebração da transação e a assinatura do respectivo termo poderá ser condicionada à exigência de assinatura de um termo de ajustamento de conduta, prévio, suplementar ou incluso no próprio termo de transação (art. 25, caput). Demais disso, assim como ocorre em relação à decisão de inadmissão da proposta de transação, parece possível a aplicação subsidiária do art. 56 da Lei $\mathrm{n}^{\circ}$ 9.784/99, de forma a permitir a interposição de recurso administrativo da eventual decisão de recusa da proposta de transação. Enfim, eventuais divergências entre termos de transação expedidos poderão ser objeto de incidente de divergência, que deverá ser apresentado no prazo de trinta dias à autoridade que houver proferido a decisão divergente. Este, uma vez instruído, será remetido à CGTC, para análise e julgamento, e não terá efeito suspensivo (art. 46, IV).

\subsubsection{Abrangência da transação tributária}

Inicialmente, cabe observar que o PL não fez menção expressa às fases em que a transação tributária poderia ocorrer: se somente quando a controvérsia já estivesse na fase judicial ou também quando esta ainda se encontrasse na fase administrativa ${ }^{456}$. Porém, parece ter seguido o entendimento de que a transação poderia ocorrer em qualquer dessas fases, pois previu, entre as modalidades de transação, a transação judicial e a administrativa por adesão (art. 30 e ss. c/c art. 43 e ss. $)^{457}$.

O PL também não fez qualquer referência em relação ao termo a quo a partir do qual a transação tributária poderia ser realizada. Apesar de não tê-lo feito expressamente, da leitura de seus dispositivos, verifica-se que a transação importará em composição de conflitos ou terminação de litígio, para extinção do crédito tributário (art. $1^{\circ}$, caput c/c art. $\left.23, \S 3^{\circ}, \mathrm{I}\right)$. Disso decorre que a transação pressupõe a existência de lançamento, somente podendo ocorrer após a constituição deste.

Demais disso, conforme já analisado no decorrer do trabalho, por conta, principalmente, da suposta indisponibilidade do crédito tributário, bem como do disposto nos arts. $3^{\circ}$, in fine e $142, \S$ único, do CTN, parte da doutrina questiona a compatibilidade

\footnotetext{
${ }^{456}$ Sobre a discussão envolvendo as fases em que transação tributária poderia ocorrer, conferir item 3.2.3 deste trabalho.

${ }^{457}$ Acerca das diversas modalidades de transação tributária previstas no PL em questão e suas respectivas peculiaridades, conferir item 4.3 deste trabalho.
} 
da transação tributária com o ordenamento jurídico pátrio. Sobretudo, quando a transação envolver a redução do tributo propriamente dito e não somente dos encargos decorrentes da mora (juros, multas, encargos, etc. $)^{458}$.

Talvez por conta dessa controvérsia, e querendo evitar possíveis questionamentos, o PL dispôs expressamente que a transação tributária, em qualquer de suas modalidades, não poderá implicar negociação do montante do tributo devido (art. $7^{\circ}, \mathrm{I}$ ). Permitiu, tão somente, a redução dos acessórios da obrigação tributária: multas, juros de mora, encargo de sucumbência e demais encargos pecuniários (art. $6^{\circ}$, caput $)^{459}$. Aproximou-se, assim, no que diz respeito à abrangência da transação, do modelo francês ${ }^{460}$.

No que tange à possibilidade de redução dos acessórios da obrigação tributária, o PL diferenciou duas situações, conforme a modalidade de transação: (a) na transação por insolvência civil, falência e recuperação judicial ou recuperação tributária, permite-se a redução de sanções pecuniárias, dos juros de mora e dos demais acréscimos pecuniários; (b) na transação em processo judicial ou na transação administrativa por adesão, permitese tão somente serem relevados os valores do encargo legal e das verbas sucumbenciais $\left(\right.$ art. $\left.6^{\circ}, \S 3^{\circ}\right)$.

Mesmo em relação às multas, juros e encargos pecuniários, foram estabelecidos limites: até $100 \%$ do valor das multas por descumprimento de obrigação acessória; até $50 \%$ do valor das multas (de mora e de ofício); até $60 \%$ do valor dos juros de mora; e até 100\% dos encargos de sucumbência e demais encargos pecuniários (art. 6, $\S 1^{\circ}$, I a IV). Além desses limites, o PL dispôs que a dispensa de juros e multa não pode ultrapassar $50 \%$ do crédito consolidado (art. $6, \S 2^{\circ}$ ). Dispôs, ainda, que a redução das multas não se aplica às multas não passíveis de redução em decorrência de previsão expressa de lei, bem como às multas de ofício em caso de sonegação, fraude ou conluio (art. $44, \S 1^{\circ}$, da Lei ${ }^{\circ}$ 9.430/96) e às multas de ofício pela falta de discriminação do valor do IPI na nota físcal

\footnotetext{
${ }^{458}$ A esse respeito, conferir item 3.3.2 deste trabalho.

${ }^{459}$ Conforme Arnaldo Sampaio Godoy, o dispositivo que prevê que a transação, em princípio, não poderá implicar em negociação do montante do tributo deve suscitar algumas controvérsias. $\mathrm{O}$ autor destaca que a mera incorporação da taxa SELIC como índice de correção pode dar ensejo à oxigenação da discussão. (GODOY, Arnaldo Sampaio de Moraes. Transação Tributária: introdução à justiça fiscal consensual. Belo Horizonte: Fórum, 2010, p. 142).

${ }^{460}$ De acordo com a legislação francesa (art. L 247 do LPF), a transação tributária pode versar sobre as penalidades administrativas (multas) e, mais recentemente, também sobre os juros. Porém, não poderá versar sobre o tributo propriamente dito. Acerca da transação tributária no Direito francês, conferir item 1.4.1.1 deste trabalho. Note, entretanto, que, diferentemente do que ocorre no Direito francês (e no Direito italiano com o accertamento con adesione), a transação tributária prevista no PL em análise poderá se realizar mesmo depois de terminada a fase do contencioso administrativo.
} 
ou de seu recolhimento (art. $80, \S 6^{\circ}$, da Lei $\left.n^{\circ} 4.502 / 64\right)\left(\operatorname{art.} 6^{\circ}, \S 4^{\circ}\right)$.

Conforme antecipado, o PL dispôs expressamente que a transação tributária, em qualquer de suas modalidades, não poderá implicar negociação do montante do tributo devido (art. $\left.7^{\circ}, \mathrm{I}\right)$. Porém, enfatizou não constituir negociação do montante do tributo as reduções que decorram da interpretação de conceitos jurídicos indeterminados ou da identificação do fato aplicável ao caso, cujo resultado seja a redução do crédito tributário (art. $\left.7^{\circ}, \S 1^{\circ}\right)$. Tem-se, assim, que o PL permitiu, indiretamente, a redução do tributo, nas hipóteses em que sua incidência não estiver devidamente demonstrada, dependendo da interpretação de conceitos indeterminados ou da identificação ou avaliação de questões de fato para tanto (art. $6^{\circ}$, caput c/c art. $7^{\circ}, \S 1^{\circ}$ ).

Tal previsão parece ser necessária e não esbarra na suposta indisponibilidade do crédito tributário, nem tampouco no princípio da legalidade tributária ${ }^{461}$. É que, conforme já antecipado, por uma questão de praticabilidade, as normas jurídicas (inclusive as tributárias) contém conceitos com certa margem de indeterminação. Por isso, para se aplicar a lei a determinado caso concreto, é necessária sua interpretação. Uma das consequências da transação prevista no PL é que a interpretação (assim como a correta aplicação da norma) poderá se dar no decorrer do procedimento de transação (art. $7^{\mathrm{o}}, \S$ $\left.1^{\circ}\right)$. Com isso, permite-se uma maior participação do contribuinte na interpretação e na aplicação da norma aos fatos tributários.

Além da suposta proibição de que a transação verse sobre o valor do tributo devido, o PL dispôs ainda que a transação não poderá afastar a aplicação ou deixar de observar tratado, acordo internacional, lei ou decreto, sob fundamento de inconstitucionalidade. Em outros termos, vedou-se a apreciação de inconstitucionalidade no bojo da transação. Excepcionaram-se dessa vedação, as hipóteses: (a) em que haja declaração de inconstitucionalidade por decisão definitiva do plenário do STF; ou (b) em que o fundamento do crédito tributário tenha sido objeto de: b1) dispensa legal ou ato declaratório do Procurador-Geral da Fazenda Nacional; b2) súmula da Advocacia-Geral da União; b3) pareceres do Advogado-Geral da União, aprovados pelo Presidente da República; b4) pareceres do Procurador-Geral da Fazenda Nacional, aprovados pelo Ministro da Fazenda; b5) solução de consulta emitida pelo Secretário da RFB; ou b6) súmula vinculante editada pelo Conselho Administrativo de Recursos Fiscais (art. $7^{\circ}$, II).

\footnotetext{
${ }^{461}$ Sobre a compatibilidade da transação tributária com o princípio da legalidade e com a obrigatoriedade de lançamento e cobrança do crédito tributário, conferir itens 3.3.1 e 3.3.2 deste trabalho.
} 
Esse dispositivo parece ser consequência de antiga controvérsia acerca da possibilidade do Executivo apreciar a constitucionalidade de atos normativos ${ }^{462}$. Note-se que, com a introdução da representação de inconstitucionalidade pela EC n ${ }^{\circ}$ 16/65, passou-se a sustentar que não mais haveria espaço para o Poder Executivo recusar aplicação a uma lei considerada inconstitucional, na medida em haveria instrumento jurídico efetivo para tanto. Mais ainda com o art. 103, da $\mathrm{CF} / 88$, que incluiu, entre os legitimados para propositura de ação direta de inconstitucionalidade e declaratória de constitucionalidade, o Presidente da República e o Governador de Estado, que são chefes do Executivo. Com efeito, tem-se que, no ordenamento brasileiro, a competência para o controle de constitucionalidade repressivo é efetuada precipuamente pelo Poder Judiciário (Supremo Tribunal Federal), que pode fazê-lo por meio do controle difuso em última instância ou do controle concentrado. Enfim, parece que o PL, seguindo essa linha, optou por vedar expressamente que o órgão competente para analisar as propostas de transação afaste a aplicação ou deixe de observar um ato normativo sob o fundamento de inconstitucionalidade, excetuadas aquelas hipóteses expressamente mencionadas.

Tal limitação de competência no âmbito dos órgãos administrativos do Poder Executivo federal não é novidade em nosso ordenamento. Dispositivo bastante semelhante ao contido no PL foi introduzido pela Lei $\mathrm{n}^{\mathrm{o}} 11.941 / 09$, que acrescentou o art. 26-A ao Decreto $n^{\circ} 70.235 / 72$, limitando a competência do Conselho Administrativo de Recursos Fiscais (CARF). Este dispositivo estabeleceu que, no âmbito dos processos administrativos fiscais, ficaria vedado aos órgãos de julgamento afastar a aplicação ou deixar de observar tratado, acordo internacional, lei ou decreto, sob o fundamento de inconstitucionalidade, excepcionando também algumas situações ${ }^{463}$. No entanto, parece que, no caso da transação, a legislação foi além. Previu outras exceções à impossibilidade de se afastar a aplicação de tratado, acordo internacional, lei ou decreto, sob o fundamento de inconstitucionalidade, além daquelas introduzidas pela Lei $n^{\circ} 11.941 / 09$. Cite-se a esse título, as hipóteses em que o fundamento do crédito tenha sido objeto de parecer do

\footnotetext{
${ }^{462}$ Sobre a possibilidade de controle repressivo de constitucionalidade pelo Executivo, conferir AMARAL JUNIOR, José Levi Mello do. Memória jurisprudencial: Ministro Aliomar Baleeiro. Brasília: Supremo Tribunal Federal, 2006. - (Série memória jurisprudencial), p. 65 et seq. Disponível em: http://www.stf.jus.br /arquivo/cms/publicacaoPublicacaoInstitucionalMemoriaJurisprud/anexo/AliomarBaleeiro.pdf. Acesso em: 16 jan. 2013.

${ }^{463}$ Para uma análise crítica acerca da possibilidade da Administração analisar a constitucionalidade das leis, bem como do dispositivo legal que previu a impossibilidade de apreciação de inconstitucionalidade de atos normativos pelo CARF, conferir MACHADO, Hugo de Brito. Não-aplicação de Lei Inconstitucional pelos Órgãos de Julgamento Administrativo. In: ROCHA, Valdir de Oliveira. Grandes Questões Atuais de Direito Tributário, São Paulo: Dialética, 2009, p. 203-213. v. 13.
} 
Procurador-Geral da Fazenda Nacional, aprovado pelo Ministro da Fazenda, de solução de consulta emanada do secretário da RFB ou de súmula vinculante do próprio CARF.

Finalmente, embora seja permitida a transação tributária nas hipóteses em que a interpretação da legislação seja conflituosa ou litigiosa (art. $6^{\circ}$, caput, in fine), estabeleceu-se expressamente que a transação tributária não poderá versar sobre matéria de fato ou de direito que transcendam os limites do conflito ou litígio (art. $7^{\circ}$, III). Em outras palavras, a transação somente poderá tratar de matérias que já façam parte do litígio (administrativo ou judicial). Ora, parece razoável que assim o seja, vedando-se que a Administração transacione em relação à matéria que sequer é discutida nos autos do processo administrativo ou judicial. Tal vedação, todavia, parece mitigada em relação à transação em processo judicial. Nessa modalidade, permite-se sejam levados em consideração elementos não constantes do processo judicial (art. 30, caput). Demais disso, está previsto que a transação poderá incluir matérias pertinentes àquelas deduzidas em juízo e com estas relacionadas ou conexas (art. 30, § $3^{\circ}$ ). Quer dizer, em realidade, permite-se que a transação em processo judicial transcenda os limites do litígio.

Em síntese, a transação tributária não pode abranger toda e qualquer matéria, encontrando alguns limites. Em regra, pode ocorrer tanto na fase judicial quanto na administrativa, bastando para tanto que tenha havido o lançamento do crédito tributário. No entanto, somente poderá implicar em redução dos encargos da mora (multa, juros, encargos de sucumbência e demais encargos pecuniários); e isso, a depender da modalidade de transação em questão, e desde que observados alguns limites. Ademais, observa-se que o PL vedou expressamente que a transação implique em negociação dos tributos devidos. Tal vedação é, porém, mitigada quando a redução decorra da interpretação de conceitos jurídicos indeterminados ou da identificação do fato em determinado caso concreto. Vedou-se, também, que a transação afaste a aplicação de atos normativos sob fundamento de inconstitucionalidade, ressalvadas algumas hipóteses específicas. Enfim, vedou-se, ainda, que a transação verse sobre matéria de fato ou de direito que transcenda os limites do litígio. Porém, também aqui, essa previsão parece mitigada na hipótese de transação em processo judicial, na medida em que essa permite a inclusão de matérias relacionadas ou conexas àquelas deduzidas em juízo (art. 30, $\S 3^{\circ}$ ). 


\subsection{Modalidades de transação no Projeto de Lei no 5.082/2009}

O Projeto de Lei Geral de Transação em matéria tributária buscou abranger várias situações em que a transação entre fisco e contribuinte poderia ocorrer. Nesse sentido, o PL contemplou modalidades diferentes de transação tributária, cada qual com suas próprias peculiaridades. A previsão de modalidades transacionais distintas decorre do princípio da eficiência. É que, quanto mais situações puderem ser abarcadas pela transação tributária, mais eficiente será esse instrumento na resolução de conflitos.

Atualmente, encontram-se previstas no PL as seguintes modalidades de transação tributária: transação em processo judicial (item 4.3.1); transação em insolvência civil, recuperação judicial e falência (item 4.3.2); transação por recuperação tributária (item 4.3.3); e transação administrativa por adesão (item 4.3.4). A seguir, essas modalidades serão analisadas de forma sintética, a fim de explicitar seu conteúdo, suas diferenças, além de tentar compreender algumas opções legislativas.

\subsubsection{Transação em processo judicial}

Essa modalidade de transação tem como pressuposto, como seu próprio nome indica, a existência de um litígio que seja objeto de um processo judicial em curso. Não basta, entretanto, qualquer processo judicial para que se possa realizar a transação. Necessário que nesse processo se esteja discutindo o crédito tributário que se pretende transacionar e que esse crédito tenha sido devidamente constituído por lançamento por homologação ou por lançamento de ofício (art. 30, $\left.\S 1^{\circ}, \mathrm{I}\right)^{464}$.

Nesse sentido, admite-se a transação em processo judicial tanto durante o trâmite de ações propostas pelo fisco (e.g. execuções fiscais), quanto de ações propostas pelos próprios contribuintes (e.g. ações anulatórias, ações declaratórias de inexigibilidade de crédito fiscal, embargos à execução fiscal). Optou-se, no entanto, por não se admitir a transação judicial em ações mandamentais e ações cautelares (art. $30, \S 5^{\circ}$ ). Tal opção se deu, possivelmente, pois essas ações não têm por objeto o crédito tributário em si: (a) no mandado de segurança, questiona-se ato ilegal da autoridade dita coatora ${ }^{465}$; (b) na ação

\footnotetext{
${ }^{464}$ O PL excluiu, ainda que implicitamente, a possibilidade de realização de transação em processo judicial em relação aos créditos tributários constituídos por outra modalidade de lançamento diversa daquelas mencionadas no inciso I, do $\S 1^{\circ}$, do art. 30: é o caso do lançamento por declaração.

${ }^{465} \mathrm{O}$ mandado de segurança está previsto no art. $5^{\circ}$, LXIX, da $\mathrm{CF} / 88$, estando atualmente regulamentado pela Lei $n^{\circ} 12.016 / 2009$. Note que, ainda que o mandado de segurança possa, eventualmente, impactar o crédito, ele não tem por objeto o crédito tributário em si, mas suposto ato ilegal praticado por autoridade
} 
cautelar busca-se resguardar a utilidade de eventual provimento jurisdicional favorável.

Além disso, embora o objeto da transação esteja, em princípio, definido pelo litígio existente entre fisco e contribuinte, conforme definido na petição inicial da ação judicial em curso (art. 30, caput), eventualmente, a transação poderá abranger também outras matérias, desde que relacionadas ou conexas com aquelas deduzidas em juízo (art. $\left.30, \S 3^{\circ}\right)$. Ademais, admite-se que essa modalidade de transação leve em consideração, para a solução da matéria de fato ou de direito controvertida, elementos não constantes no processo judicial (art. 30, caput, in fine). Trata-se de uma tentativa válida de garantir uma maior efetividade ao instrumento da transação tributária. Porém, deve-se ter cautela para evitar que, sob o pretexto de tratar-se de matéria conexa, sejam incluídas na transação matérias totalmente distintas daquelas deduzidas em juízo.

O projeto optou, ainda, por estabelecer um marco temporal a partir do qual a transação em processo judicial não mais poderá ser realizada. Diferenciou este marco em razão da existência ou não de execução fiscal em curso: (a) havendo execução fiscal: poderão as partes transacionar somente até o julgamento em primeira instância dos respectivos embargos ou, na ausência destes, até a publicação da decisão que designar a data do leilão (art. $30, \S 1^{\circ}$, III); (b) não havendo execução físcal: as partes poderão transacionar em qualquer fase do processo até a publicação do despacho, positivo ou negativo, de admissibilidade de recurso especial ou extraordinário interposto por qualquer das partes (art. 30, $\left.\S 1^{\circ}, \mathrm{II}\right)$. Arnaldo Godoy sustenta que o fato de recursos extraordinários e especiais serem marcos temporais para a realização da transação resulta de que não se avoca administrativamente processo em curso em tribunal superior ${ }^{466}$. Tal diferenciação entre as situações em que há execução fiscal em curso e aquelas outras em não há não parece ter nenhum fundamento plausível. Isso porque, terminada a discussão na esfera administrativa, se o contribuinte se antecipa à propositura da execução fiscal e propõe uma ação anulatória de débito fiscal (ou declaratória de inexistência de relação jurídica) e obtém um provimento favorável para suspender a exigibilidade do crédito até decisão final, impedindo a propositura da execução fiscal, ele poderá transacionar até que a discussão atinja as ulteriores instâncias. Entretanto, caso aguarde a propositura da execução fiscal para impugnar o crédito fiscal por meio dos embargos, terá ele somente até o julgamento em primeira instância para fazê-lo, ainda que essa decisão lhe seja

coatora que viola direito líquido e certo da parte.

${ }^{466}$ GODOY, Arnaldo Sampaio de Moraes. Transação Tributária: introdução à justiça fiscal consensual. Belo Horizonte: Fórum, 2010, p. 154. 
favorável.

Por fim, note-se que, conforme se depreende da redação do PL, a proposta de transação em processo judicial será formulada e analisada não pelo juiz, mas sim pela autoridade competente indicada pela CGTC, assim como ocorre com as demais propostas de transação (art. 30, $\S 2^{\circ}$ ). No entanto, como bem lembrado por Helena Marques Junqueira, ainda que não haja qualquer referência à necessidade de homologação judicial do acordo, na seção relativa à transação em processo judicial, essa se faz imprescindível para que venha a surtir efeitos para as partes $\left(\operatorname{art.} 23, \S 2^{\circ}\right)^{467}$.

Enfim, apesar do PL ser silente a esse respeito, parece que, quando da homologação, o juiz não deverá entrar no mérito do conteúdo da transação propriamente dita, devendo se ater à análise do preenchimento das condições e requisitos legais para que a transação ocorra.

\subsubsection{Transação no caso de insolvência civil, falência ou recuperação judicial}

Outra modalidade de transação prevista pelo PL é aquela no caso de insolvência civil, falência ou recuperação judicial. Trata-se de um instrumento para recuperar créditos tributários de devedores em sérias dificuldades financeiras que parece ter sido inspirado na transazione fiscale prevista no Direito italiano ${ }^{468}$. Tem como pressuposto o fato do devedor se encontrar em uma das modalidades de concurso de credores acima mencionadas (art. 32, caput). Admite-se, também, essa modalidade em outras hipóteses de concurso de credores com insolvência civil declarada (art. 32, § $2^{\circ}$ ). Este parece ser o caso, por exemplo, da liquidação extrajudicial das instituições financeiras ${ }^{469}$.

467 JUNQUEIRA, Helena Marques. Transação Tributária. Tese (Doutorado em Direito), Faculdade de Direito da Pontifícia Universidade Católica de São Paulo, 2009, p. 223.

468 Sobre a transazione fiscale no Direito italiano, conferir item 1.4.2.2. Também sobre essa questão, conferir BUSA, Vincenzo. Gli instituti deflativi del contenzioso nell'esperienza italiana: a experiência italiana sobre transação e conciliação em matéria tributária e demais modalidades alternativas de solução de controvérsias fiscais. In: TÔRRES, Heleno Taveira (Coord.). Direito Tributário Internacional Aplicado Volume V, São Paulo: Quartier Latin, 2008, p. 538.

469 A liquidação extrajudicial das instituições financeiras está regulada na Lei $\mathrm{n}^{\circ}$ 6.024/74. Trata-se de concurso de crédito com finalidade semelhante àquela da falência, isto é, a apuração do passivo e do ativo, a alienação deste e o conseqüente pagamento dos credores. Em conformidade com o disposto na legislação, a decretação da insolvência poderá ocorrer: (a) ex oficio, pelo BCB; (b) a requerimento dos administradores da intervenção; ou (c) por proposta do interventor. O papel do liquidante nesse procedimento será dúplice: semelhante ao do síndico na falência, mas também àquele do juízo falimentar, dirigindo o procedimento habilitatório e julgando as habilitações. Para uma análise detalhada do procedimento e dos efeitos da liquidação extrajudicial das instituições financeiras, conferir TZIRULNIK, Luiz. Intervenção e Liquidação Extrajudicial das Instituições Financeiras. São Paulo: RT, 2000. 
Conforme Helena Marques Junqueira, a previsão legal dessa modalidade de transação configura um divisor de águas na cobrança de créditos fazendários. Permite que a Fazenda conceda um tratamento diferenciado aos créditos tributários de devedores em situação concursal. Isso porque, considerando que o crédito tributário não estava sujeito a concurso de credores, era comum que esses continuassem a ser cobrados por meio de execuções, que estavam fadadas ao fracasso na sua grande maioria das vezes ${ }^{470}$.

A concessão de um tratamento diferenciado aos créditos tributários para contribuintes em situação concursal não é novidade em nosso ordenamento. Dispositivo do gênero encontra-se também previsto no art. 155-A, $\S 3^{\circ}$, do CTN, bem como no art. 68 , da Lei $\mathrm{n}^{\mathrm{o}}$ 11.101/2005 (Lei de Falências e Recuperação Judicial). Esses dispositivos prevêem que as Fazendas podem deferir parcelamentos com regras específicas para aqueles que se encontrem em recuperação judicial. Visa a permitir que as empresas em recuperação judicial possam regularizar sua situação, inclusive em relação aos créditos tributários. Não obstante o decurso de quase 8 (oito) anos da introdução desses dispositivos, não foi editada lei específica sobre a matéria, o que impede as empresas em recuperação judicial de se beneficiarem de tal parcelamento, fazendo com que procurem o Judiciário para fazer valer esse direito não obstante a inexistência de lei específica, conforme preceitua o $\S 4^{\mathrm{o}}$, do art. 155-A, do $\mathrm{CTN}^{471}$. Vê-se, pois, com bons olhos a introdução dessa modalidade de transação, que concede tratamento específico às empresas nas hipóteses de recuperação judicial, falência ou insolvência, inclusive com a possibilidade de parcelemento de seus débitos.

Nessa modalidade de transação, diferentemente das demais, a proposta de transação tributária é efetuada pela própria Fazenda Nacional, nos termos de resolução da CGTC $^{472}$, sendo apresentada perante o juízo competente (art. 32, caput). Embora não haja especificação se o juízo competente a que faz referência o dispositivo seria o juízo do concurso de credores ou onde o crédito tributário estaria sendo discutido (e.g. juízo da

\footnotetext{
470 JUNQUEIRA, Helena Marques. Transação Tributária. Tese (Doutorado em Direito), Faculdade de Direito da Pontifícia Universidade Católica de São Paulo, 2009, p. 224.

${ }^{471}$ A esse respeito, importa salientar ter sido recentemente publicado o enunciado $\mathrm{n}^{\circ} 55$, do Conselho da Justiça Federal (CJF), aprovado na $1^{\text {a }}$ Jornada de Direito Comercial, com a seguinte redação: "O parcelamento do crédito tributário na recuperação judicial é um direito do contribuinte, e não uma faculdade da Fazenda Pública, e, enquanto não for editada lei específica, não é cabível a aplicação do disposto no art. 57 da Lei n. 11.101/2005 e no art. 191-A do CTN". Disponível em: <http://www.jf.jus.br/cjf/CEJCoedi/Enunciados\%20aprovados\%20na\%20Jornada\%20de\%20Direito\%20Comercial.pdf/viewsearchterm= enunciados>. Acesso em: 12 mar. 2013. Note que, embora não vinculem os juízes a seguirem o seu entendimento, os enunciados são muitas vezes considerados por julgadores quando de suas decisões.

472 GODOY, Arnaldo Sampaio de Moraes. Transação Tributária: introdução à justiça fiscal consensual. Belo Horizonte: Fórum, 2010, p. 152.
} 
execução fiscal), depreende-se dos demais dispositivos do projeto que esse seria efetivamente o do juízo concursal. Isso porque, a legislação prevê que essa modalidade de transação deverá respeitar os direitos do insolvente ou do falido, da Administração da massa falida e dos titulares de créditos preferenciais (art. $32, \S 1^{\circ}$, in fine). Ora, somente o juízo do concurso de credores teria como preservar o direito destes últimos, na medida em que a habilitação de créditos se dá nos autos do processo que tramita em seu juízo.

Demais disso, nessa modalidade de transação, permite-se que a proposta apresentada pelo fisco contemple também a remissão parcial do crédito, com base na situação econômica do sujeito passivo, além da anistia das multas, do parcelamento ou da dação em pagamento (art. 32, $\S 2^{\circ}$ ). Isso é claro, desde que estas medidas se verifiquem imprescindíveis para a recepção, total ou parcial, dos créditos tributários. Note que na hipótese da proposta de transação contemplar a remissão parcial do crédito, esta estará abrangendo em realidade o tributo propriamente dito. Embora essa previsão, em princípio, contradiga o dispositivo que proíbe que se negocie o valor do tributo devido em qualquer das modalidades de transação (art. $7^{\circ}$, I), de fato, não o faz. É que, nesse caso, não é a transação propriamente dita que implica em redução do tributo, mas a remissão prevista no art. 172 do $\mathrm{CTN}^{473}$. E, aparentemente, não há nada que vede que essa o faça, desde que respeitados os critérios estabelecidos no referido dispositivo legal ${ }^{474}$.

Finalmente, caso sobrevenha a recuperação do sujeito passivo que se submeter à transação por insolvência, e a extinção da insolvência ou da falência, deverá ele firmar termo de ajustamento de conduta comprometendo-se a manter sua regularidade fiscal em relação a todos os tributos federais, nos cinco anos subsequentes, sob pena de cobrança da

\footnotetext{
${ }^{473}$ Art. 172. A lei pode autorizar a autoridade administrativa a conceder, por despacho fundamentado, remissão total ou parcial do crédito tributário, atendendo:

I - à situação econômica do sujeito passivo;

II - ao erro ou ignorância excusáveis do sujeito passivo, quanto a matéria de fato;

III - à diminuta importância do crédito tributário;

IV - a considerações de eqüidade, em relação com as características pessoais ou materiais do caso;

V - a condições peculiares a determinada região do território da entidade tributante.

Parágrafo único. O despacho referido neste artigo não gera direito adquirido, aplicando-se, quando cabível, o disposto no artigo 155 .

${ }^{474}$ Essa visão parece se coadunar com o posicionamento de Fábio Fanucchi acerca da remissão. De acordo com com o autor: "O crédito tributário poderá ser objeto de remissão, total ou parcial, desde que a lei autorize tal perdão e que a autoridade administrativa a conceda em despacho fundamentado [...]". (FANUCCHI, Fábio. Curso de Direito Tributário Brasileiro - Volume 1. São Paulo: Resenha Tributária, 1975, p. 340). Paulo de Barros Carvalho por sua vez, assevera que: "Remissão, do verbo remitir, é perdão, indulgência, indulto [...] No direito tributário brasileiro é forma extintiva da obrigação, se e somente se houver lei autorizadora". E prossegue alguns parágrafos mais adiante: "Remitindo, o Estado dispensa o pagamento do crédito relativo ao tributo [...]"(CARVALHO, Paulo de Barros. Curso de Direito Tributário. São Paulo: Saraiva, 2012, p. 541-542, grifo nosso).
} 
diferença dos débitos que foram objeto da transação, acrescidos dos encargos legais (art. 33). Ademais, havendo dolo, fraude ou simulação na configuração do estado de insolvência do sujeito passivo, ou constatado que esse não se utilizou de denúncia espontânea antes da transação, o referido termo não poderá ser concluído ou será nulo, sem prejuízo das consequências penais cabíveis (art. 34). Com isso, quer-se evitar abusos: que o sujeito passivo entre em estado de insolvência propositadamente, com o intuito de ter sua dívida tributária reduzida; assim como que, efetuada a transação com as reduções a ela inerentes, o sujeito passivo venha, logo em seguida, deixar de cumprir suas obrigações tributárias para com o fisco.

\subsubsection{Transação por recuperação tributária}

Uma terceira modalidade de transação prevista no PL é aquela por recuperação tributária. Trata-se, também, de um instrumento para recuperar créditos tributários de devedores em situação de crise econômico-financeira. Tem como fundamentos não somente o princípio da preservação da empresa, como também a função social exercida pela empresa e o estímulo à atividade econômica. Permite, com isso, a manutenção da percepção de tributos pelo Estado (art. 35, caput). Em termos leigos, seu objetivo é preservar a "galinha dos ovos de ouro", recuperando-a para gerar novos "ovos".

Porém, contrariamente à modalidade de transação vista no item anterior, essa modalidade de transação não se aplica àqueles que podem requerer a recuperação judicial (e.g. empresários e sociedades empresárias), nem às empresas públicas e sociedades de economia mista; tampouco se aplica às instituições financeiras, entidades de previdência complementar, seguradoras e outras expressamente excluídas (art. 35, § único). Ademais, apesar de não haver disposição expressa nesse sentido, considerando seus fundamentos e pressupostos, essa modalidade parece também não se aplicar às pessoas físicas. Enfim, essa modalidade de transação será aplicável, sobretudo, às sociedades simples.

Da análise de seus dispositivos, verifica-se que essa modalidade de transação nada mais é do que uma forma de recuperação alternativa à recuperação judicial da Lei $\mathrm{n}^{\circ}$ 11.101/2005. Tanto isso é verdade que, seu fundamento (art. 35, caput) e vários de seus dispositivos, notadamente aqueles que estabelecem os requisitos subjetivos (art. 36) e objetivos (art. 37) da proposta de transação, assemelham-se àqueles constantes da Lei de Falências e Recuperação Judicial. Entretanto, seu objeto é mais limitado, envolvendo 
apenas débitos tributários, notadamente aqueles cujo credor seja a União ${ }^{475}$.

Em relação aos requisitos subjetivos (quem pode requerer a transação), tem-se que o sujeito passivo deve exercer atividade regular por mais de 2 anos e não pode ele, nem seus controladores, administradores ou gestores terem sido condenados por fraude ou crimes contra a ordem tributária nos últimos cinco anos; tampouco podem, no mesmo período, ter celebrado transação com a Fazenda Nacional que tenha implicado redução do crédito tributário (art. 36, I a III). Em relação aos requisitos objetivos (documentos que devem instruir o pedido de transação), devem ser apresentados os seguintes documentos: exposição das causas da crise, demonstrações contábeis do sujeito passivo, relação dos débitos tributários com a Fazenda Nacional, laudo econômico-financeiro e de avaliação dos bens e ativos do sujeito passivo, relação de bens particulares dos controladores e administradores, extratos das contas bancárias, além de vários outros (art. 37, I a XII).

Essa multitude de condições e os inúmeros documentos que precisam ser apresentados para se formular uma proposta de transação nessa modalidade tem gerado críticas da doutrina ${ }^{476}$. Em resumo, consideram-se como excessivas e extremamente burocráticas as imposições do normativo proposto, destacando que as várias exigências previstas no Projeto de Lei em trâmite no Congresso inviabilizariam, na prática, a utilização, pelos contribuintes, da transação por recuperação tributária.

Realmente, não há como negar que são várias as condições para que o sujeito passivo possa formular uma proposta de transação nessa modalidade. Entretanto, discorda-se em parte das críticas efetuadas. É que, grande parte dessas condições estão contidas também na Lei de Falências e Recuperação Judicial ${ }^{477}$. E, se essa modalidade de

\footnotetext{
${ }^{475}$ Conforme se depreende do disposto no art. $1^{\circ}$, caput, do PL n ${ }^{\circ} 5.082 / 2009$.

${ }^{476}$ É o caso de Hugo de Brito Machado que, referindo-se aos dispositivos que tratavam dessa modalidade de transação no anteprojeto, destaca: “[...] Apenas impõe deveres ao contribuinte interessado e atribui ampla faculdade à Administração Tributária [...]”. (MACHADO, Hugo de Brito. Transação e arbitragem no âmbito tributário. In: SARAIVA FILHO, Oswaldo Othon de Pontes; GUIMARÃES, Vasco Branco (Orgs.). Transação e Arbitragem no Direito Tributário. Belo Horizonte: Forum, 2008, p. 133). No mesmo sentido é o posicionamento de Helena Marques Junqueira. De acordo com a autora: "Pena que objetivos tão nobres e 'politicamente corretos' - irrepreensíveis na forma como estão dispostos - serão, praticamente, impossíveis de serem alcançados. Os requisitos impostos pelo art. 36 e as extensas exigências do art. 37, na nossa opinião, inviabilizam a transação por recuperação tributária. As imposições excessivas e extremamente burocráticas do projeto de lei fogem do espírito de modernidade e eficência que permeia a transação tributária. Só de exigências para a presentação da proposta de transação são doze incisos do art. 37, cuja leitura já é bastante cansativa". (JUNQUEIRA, Helena Marques. Transação Tributária. Tese (Doutorado em Direito), Faculdade de Direito da Pontifícia Universidade Católica de São Paulo, 2009, p. 225).

${ }^{477}$ A esse respeito, conferir os arts. 48 e 51, da Lei $\mathrm{n}^{\mathrm{o}}$ 11.101/2005. Esses dispositivos estabelecem que somente poderão requerer a recuperação judicial de que trata aquele normativo: aqueles que exercerem regularmente suas atividades há mais de 2 anos; aqueles que não sejam falidos (ou, se forem, tiverem sido declaradas extintas suas responsabilidades); aqueles que não tenham sido beneficiados pela recuperação nos
} 
transação é uma forma de recuperação alternativa à recuperação judicial da Lei $\mathrm{n}^{\mathrm{o}}$ 11.101/2005, parece razoável que contenha condições análogas.

Note-se que o objetivo do PL não parece ter sido conferir condições mais benéficas do aquelas estabelecidas para o gozo da recuperação judicial. Ambas tem por objetivo a recuperação das empresas que se encontram em dificuldades financeiras: uma em relação a totalidade das dívidas; outra exclusivamente em relação àquelas de natureza tributária. Não se quer, porém, que essa recuperação se dê em quaisquer circunstâncias, razão pela qual exige-se uma série de documentos e impõem-se várias condições.

Outra peculiaridade dessa modalidade de transação consiste no fato de que, quando da apresentação da proposta de transação pelo sujeito passivo, este deverá fornecer também uma proposta de termo de ajustamento de conduta (art. 37, X), Nesta proposta, o sujeito passivo se comprometerá a manter sua atividade empresarial e sua regularidade tributária perante a União pelo prazo de, ao menos, três anos.

Demais disso, deverá apresentar também um plano de recuperação tributária (art. 38, caput). Este plano contemplará a origem dos recursos e a forma com que se pretende efetuar o pagamento dos créditos tributários devidos. Permite-se, inclusive, que esses sejam pagos por meio de dação em pagamento de bens imóveis, na forma da lei. Entretanto, o prazo total para pagamento dos créditos contidos no plano de recuperação tributária não poderá ultrapassar sessenta meses (art. 38, § único).

\subsubsection{Transação administrativa por adesão}

Por fim, uma quarta e última modalidade de transação prevista no Projeto de Lei consiste na denominada transação administrativa por adesão. Trata-se de modalidade transacional aplicável para solução de controvérsias jurídicas em matéria tributária, inclusive quando haja repercussão geral (art. 43, caput). Permite que sejam apresentadas propostas de transação em casos de discussão dos aspectos jurídicos do crédito $^{478}$.

últimos 5 anos; e aqueles que não tenham sido condenados por crimes falimentares. Além do mais, esses dispositivos estabelecem como requisitos do pedido de recuperação judicial, a apresentação: da situação patrimonial do devedor e as razões da crise econômico-financeira por que passa; das demonstrações contábeis; da relação integral de empregados, das certidões de regularidade fiscal; dos extratos das contas bancárias; da relação dos bens particulares dos controladores e dos administradores, etc.

478 JUNQUEIRA, Helena Marques. Transação Tributária. Tese (Doutorado em Direito), Faculdade de Direito da Pontifícia Universidade Católica de São Paulo, 2009, p. 228. Para a autora, a discussão sobre o crédito tributário poderia versar tanto em relação à inconstitucionalidade quanto à ilegalidade da exigência do crédito tributário. 
Tem como pressuposto duas situações: (a) uma lei específica prevendo-a; ou (b) autorização do Ministro da Fazenda e do Advogado-Geral da União, com base na jurisprudência pacífica do Supremo Tribunal Federal ou de tribunais superiores; hipótese em que competirá à CGTC, analisando as solicitações de transação recebidas, encaminhar aquelas suscetíveis de transação por adesão ao Ministro da Fazenda para que este decida autorizar ou não a transação (art. $\left.43, \S 1^{\circ}\right)$.

Essa modalidade de transação tem como particularidade o fato da controvérsia jurídica poder afetar inúmeros contribuintes. Permite-se que seja dada uma mesma solução a todos aqueles que se encontrem em idêntica situação. Os requisitos e condições para a adesão dos interessados serão disciplinados por resolução administrativa da CGTC. Esta terá efeitos gerais e será aplicada aos casos idênticos, cujos interessados preencham os requisitos tempestivamente (art. $43, \S 2^{\circ}$ ).

Para tanto, o interessado deverá apresentar pedido de adesão perante a unidade da PGFN ou da SRFB de seu domicílio, juntando prova de ter cumprido os requisitos estabelecidos na referida resolução ${ }^{479}$. Feito isso, o sujeito passivo poderá requerer ao juiz o sobrestamento do processo em curso por até noventa dias. Ao final, atendidos os pressupostos, a forma e os prazos fixados na resolução, a autoridade administrativa formalizará o termo de transação (art. $44, \S 1^{\circ}$ e $2^{\circ}$ ).

A transação administrativa por adesão é a modalidade de transação que propõe se adequar à igualdade de tratamento dos contribuintes, evitando, assim, que alguns sejam beneficiados a despeito de outros que se encontrem na mesma situação. A igualdade tributária pressupõe que a Administração conceda um mesmo tratamento àqueles que se encontram em idêntica situação. Entretanto, vale destacar que a igualdade de condições, que enseja a igualdade de tratamento, não pode ser generalizada, Devem ser observadas as peculiaridades de cada situação, de acordo com o caso concreto ${ }^{480}$.

Finalmente, é de se ressaltar que, na hipótese de transação por adesão, que

\footnotetext{
${ }^{479} \mathrm{~A}$ esse respeito, importa salientar serem os arts. 43 , $\S 3^{\circ}$ e 44 , caput, do PL redundantes. Ambos dizem exatamente a mesma coisa: que o sujeito passivo (ou "interessado") deverá apresentar seu pedido (ou "proposta") de adesão perante a Fazenda Nacional (PGFN ou SRFB, de seu domicílio), com prova de que atende aos requisitos estabelecidos (por resolução) pela CGTC. Sendo assim, parece conveniente a supressão do $43, \S 3^{\circ}$, posto que este dispositivo é menos detalhado que o subsequente.

${ }^{480}$ Sobre a compatibilidade da transação em matéria tributária com o princípio da igualdade, conferir item 3.3.4 deste trabalho.
} 
dependa de autorização do Ministro da Fazenda e do Advogado-Geral da União (art. 43, I), tem-se que a principal justificativa para sua realização é a abreviação e finalização do litígio tributário entre as partes. É que, considerando que essa modalidade transacional pressupõe jurisprudência pacífica de nossa Corte Suprema ou dos tribunais superiores, a questão jurídica de fundo já estará, de fato, resolvida, seja a favor do fisco, seja a favor do contribuinte. Será apenas uma questão de tempo para que casos semelhantes cheguem a essas instâncias e recebam a mesma solução. Nessas condições, tem-se que a celebração da transação apenas antecipará um resultado previsto e provável, reduzindo o número de ações em trâmite, o que importará um ganho em eficiência na prestação jurisdicional ${ }^{481}$.

\subsection{Efeitos das etapas do procedimento de transação do Projeto de Lei $\mathbf{n}^{0}$ $5.082 / 2009$}

Em conformidade com a redação atual do PL, a transação em matéria tributária acarreta diferentes efeitos no crédito tributário. Esses efeitos, por vezes, são gerados pela simples apresentação da proposta de transação pelo contribuinte (item 4.4.1). Outras vezes, são gerados pela admissão da proposta de transação pela autoridade competente (item 4.4.2). Alguns deles decorrem da celebração da transação e assinatura de seu respectivo termo pelas partes envolvidas (item 4.4.3). Finalmente, outros efeitos somente ocorrerão quando do cumprimento integral das condições e obrigações pactuadas no termo de transação assinado pelas partes (item 4.4.4).

\subsubsection{Da simples apresentação da proposta de transação}

Para evitar que a apresentação de propostas de transação totalmente descabidas e sem qualquer fundamento acarretasse efeitos na cobrança do crédito tributário pelo fisco, optou-se por postergar parte dos efeitos jurídicos da transação para quando da efetiva admissão da proposta. É que, será somente então que se fará uma análise preliminar do

\footnotetext{
481 JUNQUEIRA, Helena Marques. Transação Tributária. Tese (Doutorado em Direito), Faculdade de Direito da Pontifícia Universidade Católica de São Paulo, 2009, p 229 et seq. Nesse sentido, a autora destaca que se a jurisprudência pacífica for favorável ao contribuinte não haveria razão para que este celebrasse transação; porém, admite que ele poderia aceitar efetuar o pagamento de uma parte do crédito para colocar fim ao litígio em tempo menor do aquele necessário à obtenção de uma decisão definitiva em seu processo. Por outro lado, se a a jurisprudência for desfavorável ao contribuinte (e favorável ao fisco), não haveria, em princípio, razão para que a União assegurasse qualquer vantagem para que o contribuinte efetuasse o pagamento do tributo devido; porém, destaca que, em qualquer uma das situações acima, a transação poderia se justificar pela abreviação da solução dos casos pendentes, reduzindo o número de ações que envolvam questões jurídicas já definidas pela jurisprudência, trazendo ganho em eficiência e reduzindo os custos de manutenção das atividades do Poder Judiciário.
} 
preenchimento dos requisitos e das condições legais da proposta apresentada pelo sujeito passivo. Nesse sentido, a redação atual do PL parece ter limitado consideravelmente os efeitos da simples apresentação da proposta de transação.

Um primeiro efeito atribuído à apresentação de uma proposta de transação é o efeito impeditivo da apresentação de nova proposta. Em outras palavras, a apresentação da proposta obsta que se venha futuramente apresentar uma nova proposta em relação à matéria objeto do litígio ou conflito (art. 16, § único). Dessa forma, apresentada a proposta em relação a um determinado litígio, ainda que essa não venha a ser admitida, ficará a parte impedida de apresentar nova proposta, mesmo que essa contenha outros termos e condições mais benéficos a outra parte.

A apresentação da proposta de transação implica também na suspensão da pretensão punitiva estatal (art. 54, caput). Tal efeito se dá em relação aos crimes contra ordem tributária (arts. $1^{\circ}$ e 2 da Lei $n^{\circ} 8.137 / 90$ ), aos crimes de apropriação indébita previdenciária (art. 168-A do CP) e aos crimes de sonegação de contribuição previdenciária (art. 337-A do CP) $)^{482}$. Estabeleceu-se, assim, que a ação penal por quaisquer dos delitos acima mencionados fica suspensa a partir da apresentação da proposta de transação ${ }^{483}$. Seguiu-se o modelo aplicável aos parcelamentos ${ }^{484}$.

No entanto, para evitar que fossem apresentadas propostas de transação tão somente com o intuito de suspender a pretensão punitiva dos agentes dos referidos crimes, talvez fosse o caso de postergar também esse efeito para quando da efetiva admissão da proposta. Ademais, para evitar dúvidas, parece também conveniente explicitar que será restabelecida a pretensão punitiva quando rejeitada a proposta de transação pela autoridade competente, não concluída a transação em seu prazo legal ou não cumpridas as condições estabelecidas no termo de transação assinado.

\footnotetext{
482 Acerca dos efeitos da transação tributária na esfera penal, conferir MACHADO, Hugo de Brito. Transação e arbitragem no âmbito tributário. In: SARAIVA FILHO, Oswaldo Othon de Pontes; GUIMARÃES, Vasco Branco (Orgs.). Transação e Arbitragem no Direito Tributário. Belo Horizonte: Forum, 2008, p. 120-124.

${ }^{483}$ Nesse aspecto, discorda-se do posicionamento de Helena Marques Junqueira, que coloca a suspensão da pretensão punitiva entre os efeitos da admissão da proposta de transação. (JUNQUEIRA, Helena Marques. Transação Tributária. Tese (Doutorado em Direito), Faculdade de Direito da Pontifícia Universidade Católica de São Paulo, 2009, p. 218-219).

${ }^{484}$ A esse respeito, conferir art. $9^{\circ}$ da Lei $n^{\circ} 10.684 / 03$ e art. 68 da Lei $n^{\circ} 11.941 / 09$. Esses dispositivos possuem redação bastante semelhante à redação do art. 54, caput do PL n ${ }^{\circ}$ 5.082/2009, que trata dos efeitos penais da transação. Estabelecem que fica suspensa a pretensão punitiva do Estado durante o período em que a pessoa jurídica relacionada com o agente dos aludidos crimes estiver incluída no regime de parcelamento, estabelecendo ainda que não corre a prescrição criminal nesse período.
} 
Em conclusão, os efeitos gerados pela simples apresentação da proposta de transação são limitados, restringindo-se: (a) ao efeito impeditivo de apresentação de uma nova proposta (art. 16, § único); e (b) à suspensão da pretensão punitiva nos crimes de natureza tributária a quer faz menção o dispositivo (art. 54, caput).

\subsubsection{Da admissão da proposta de transação}

A maior parte dos efeitos ocasionados durante o procedimento de transação tributária ocorrem com a efetiva admissão da proposta de transação. Esses efeitos estão em grande parte disciplinados no art. 20 e seus incisos do PL $n^{0} 5.082 / 2009$. Outros, porém, decorrem da interpretação de outros dispositivos do projeto em questão, bem como das alterações propostas pelo Projeto de Lei Complementar no 469/2009.

Inicialmente, um dos efeitos da admissão da proposta de transação é a suspensão da exigibilidade do crédito tributário. Esse efeito não se encontra regulado propriamente no $\mathrm{PL} \mathrm{n}^{\mathrm{o}} 5.082 / 2009$, mas sim no Projeto de Lei Complementar $\mathrm{n}^{\mathrm{o}}$ 469/2009. Entre outras disposições, esse normativo introduz novas hipóteses de suspensão da exigibilidade do crédito tributário ao art. 151 do CTN, destacando-se a admissão de proposta para habilitação em procedimento de transação.

A suspensão da exigibilidade do crédito tributário em decorrência da admissão da proposta de transação (denominada pelo PLC admissão de proposta para habilitação em procedimento de transação) tem por consequência lógica permitir que o sujeito passivo que tenha sua proposta admitida obtenha certidão de regularidade fiscal, nos termos do disposto no art. 206 do $\mathrm{CTN}^{485}$. Tal certidão permite que o sujeito passivo obtenha financiamentos, participe de procedimentos licitatórios, etc. Enfim, autoriza-o a toda e qualquer atividade que tenha como requisito a apresentação da referida certidão.

A possibilidade de obtenção de certidão de regularidade fiscal já a partir da admissão da proposta de transação pela autoridade competente, em consonância com o que dispõe o PL (art. 20, II), é bastante criticada pela doutrina. Eurico Marcos Diniz de Santi chega a afirmar que essa situação configuraria "o paraíso das CNDs". Isso porque, dependeria tão somente da vontade do sujeito passivo, que viesse a manifestar interesse em transacionar, não obstante possa porventura mudar de idéia e decidir, posteriormente,

\footnotetext{
${ }^{485}$ Art. 206. Tem os mesmos efeitos previstos no artigo anterior a certidão de que conste a existência de créditos não vencidos, em curso de cobrança executiva em que tenha sido efetivada a penhora, ou cuja exigibilidade esteja suspensa. (grifos nossos)
} 
não concluir a transação ${ }^{486}$.

Tal crítica, embora relevante, parece despida de fundamento. Primeiro, porque, conforme já visto, não basta a apresentação da proposta de transação para que se suspenda a exigibilidade do crédito tributário e se obtenha certidão de regularidade fiscal, sendo necessária sua efetiva admissão pela autoridade competente (art. 19, § $4^{\circ}$ e art. 20, caput). Segundo, porque, tendo em conta o histórico fiscal do sujeito passivo, poderão ser exigidas garantias para a preservação do interesse da Fazenda Nacional (art. 20, § $2^{\circ}$ ), de tal sorte que, se o histórico do requerente demonstrar que se trata de um devedor contumaz, poderá a Fazenda, por exemplo, exigir carta de fiança ou outra garantia análoga, inclusive, ao que parece, para que o sujeito passivo obtenha certidão de regularidade fiscal. Terceiro, pois, ainda que se venha a obter certidão já a partir da admissão da proposta de transação, essa situação, dita "paradisíaca", somente perdurará pelo prazo de cento e oitenta dias, renováveis por igual período, prazo em que deverá obrigatoriamente ser concluído o procedimento de transação (art. 21, caput e $\S 1^{\circ}$ ). Quarto e último, porque já existem hoje outros instrumentos que permitem a obtenção de certidão de regularidade fiscal e que estão condicionados à simples manifestação da vontade do sujeito passivo, que também pode vir a se retratar: é o caso do parcelamento de débitos tributários pelo contribuinte ${ }^{487}$.

É verdade que se poderia pensar em excluir o efeito da suspensão da exigibilidade do crédito - e consequentemente o direito de obter certidão de regularidade fiscal - já a partir da admissão da proposta de transação, ou postergá-lo para quando da efetiva

${ }^{486}$ Conforme Eurico Marcos Diniz de Santi: “[...] Ocorre que, o presente anteprojeto pretende inserir uma nova modalidade para justificar a suspensão da exigibilidade, com o objetivo específico de obter certidão positiva com efeito negativo. É a chamada "habilitação para transação", fato completamente alheio [...], dependendo siplesmente da vontade de transacionar do contribuinte e pronto: abrem-se as portas do 'paraíso transacional' e liberam-se as CNDs. Sem dúvida um método eficiente para obter CNDs, mas estranho: nada tem a ver com a discussão legal sobre a exigibilidade do crédito e depende apenas da vontade do contribuinte habilitar-se no procediemento de transação e depois, é claro, como tudo depende do acordo recíproco e mútuo da vontade das partes, e também, assim como a fome ou o interesse, a vontade do contribuinte pode passar. Será que é isso mesmo?" (SANTI, Eurico Marcos Diniz de. Transação e arbitragem no Direito Tributário: paranóia ou mistificação? In: FERRAZ, Roberto (Coord). Princípios e limites da tributação 2 - Os princípios da ordem econômica e a tributação. São Paulo: Quartier Latin, 2009, p. 611-612).

${ }^{487}$ Mesmo que se considere que seja a formalização do parcelamento que suspende a exigibilidade do crédito tributário e que esta formalização pressupõe o pagamento da primeira parcela, nos termos do art. 11 da Lei $\mathrm{n}^{\mathrm{o}} 10.522 / 2002$, verifica-se que, em muitos casos, o valor dessas parcelas é ínfimo, dando a idéia também de 'paraíso das CNDs'. É o que aconteceu com o parcelamento da Lei $n^{\circ} 11.941 / 2009$, onde a parcela paga pelos contribuintes até a consolidação do parcelamento em questão, que se deu mais de dois anos depois, foi de $\mathrm{R} \$ 100,00$, mesmo em casos em que a dívida tributária era milionária. Em outras palavras, nessa situação, o sujeito passivo da obrigação tributária pôde gozar de certidão de regularidade fiscal por mais de dois anos efetuando o pagamento de uma parcela mensal de R $\$ 100,00$. 
conclusão da transação e assinatura do respectivo termo. Isso, com certeza, evitaria que contribuintes de má-fé apresentassem propostas de transação com o intuito único e exclusivo de obter certidão de regularidade fiscal. Essa alteração, no entanto, não parece ser razoável. É que, como bem pontuado por Helena Marques Junqueira, não parece lógico que o cidadão de boa-fé que busca a extinção de sua dívida tributária por meio da transação, não possa obter certidão de regularidade fiscal, ficando sujeito aos efeitos de uma execução fiscal e eventuais constrições de seu patrimônio durante o trâmite do procedimento de transação que poderá durar até 360 dias. Ainda mais quando a conclusão deste procedimento (e celebração da transação) não depende única e exclusivamente da boa vontade do contribuinte, mas também da autoridade administrativa competente ${ }^{488}$.

Pois bem, dando continuidade à análise dos efeitos da proposta de transação, temse que sua admissão acarreta também a suspensão do processo administrativo ou judicial durante o curso do procedimento de transação (art. 20, I). Vale destacar, todavia, que somente serão suspensos os processos judiciais ou administrativos em que se discuta um débito que tenha sido objeto da proposta de transação (art. 20, § $2^{\circ}$ ).

Trata-se de consequência lógica que decorre da própria suspensão da exigibilidade do crédito tributário vista anteriormente e que se assemelha aos efeitos do offer in compromise do Direito norte-americano ${ }^{489}$. Sendo o débito objeto de uma proposta de transação que foi admitida pela autoridade competente, e que, se concluída, colocará fim ao litígio, não há motivo para se continuar com a sua cobrança seja na esfera administrativa seja na esfera judicial. Até em razão do princípio da eficiência na gestão administrativo-tributária e economia processual. Ora, se o fisco, ao admitir a proposta de transação, já efetuou um juízo prévio sobre o conteúdo e a seriedade da proposta de transação (evitando propostas estapafúrdias) e as partes encontram-se em tratativas para celebração da transação e finalização do litígio, não há motivo para a Administração fazendária continuar gastando recursos para cobrar esses créditos. Deve focar seus esforços na cobrança de outros créditos tributários, que não tenham sido objeto de proposta de transação admitida.

\footnotetext{
488 JUNQUEIRA, Helena Marques. Transação Tributária. Tese (Doutorado em Direito), Faculdade de Direito da Pontifícia Universidade Católica de São Paulo, 2009, p. 218.

${ }^{489}$ Conforme já analisado no item 1.4.1.3 deste trabalho, consequência semelhante tem a proposta de acordo (offer in compromise) do Direito norte-americano. Esta impede a adoçao de medida coercitiva de cobrança até que a proposta seja rejeitada. A esse respeito, conferir também OEI, Shu-Yi. Getting More by Asking Less: Justifying and Reforming Tax Law's Offer-in-Compromise Procedure. p. 1077. Disponível em: $<$ http://papers.ssrn.com/sol3/papers.cfm?abstract_id=1909006>. Acesso em: 10 fev. 2013.
} 
Ademais, vale lembrar que a suspensão do processo administrativo ou judicial a partir da admissão da proposta de transação não prejudica a eventual futura cobrança da dívida tributária em questão. Ao que parece, a depender do histórico fiscal do contribuinte, poderão ser mantidas as garantias da dívida porventura apresentadas (art. 20, $\S 2^{\circ}$ ). Além disso, conforme se analisará a seguir, a admissão da proposta de transação implica também na interrupção da prescrição para a cobrança desses débitos.

Pois bem. Conforme já antecipado, um outro efeito da admissão da proposta de transação é a interrupção da prescrição. Esse efeito, assim como a suspensão da exigibilidade do crédito tributário, não decorre somente de previsão contida no $\mathrm{PL} \mathrm{n}^{\mathrm{o}}$ 5.082/2009, mas também de dispositivo contido no PLC $n^{\circ} 469 / 2009$. Entre outras disposições, esse normativo introduz novas causas de interrupção da prescrição ao art. 174, § único, do CTN, destacando-se “a admissão em procedimento de transação”.

Nem podia ser diferente. É que, as hipóteses de suspensão e interrupção da prescrição da ação de cobrança de créditos tributários são consideradas normas gerais em matéria de legislação tributária. E, como tais, somente podem ser disciplinadas por meio de lei complementar, por força do que dispõe o art. 146, III, “b”, da CF/88490.

Vale destacar que a prescrição é a perda do direito de cobrar o crédito tributário por meio da competente ação de execução fiscal. Em matéria tributária é, também, uma das causas de extinção do próprio crédito tributário (art. 156, V, do CTN). Ao mesmo tempo em que garante a segurança jurídica, impedindo que uma situação se perpetue indefinidamente, pune a inércia da parte que não exerce a pretensão de seu direito.

De acordo com a legislação pátria, em regra, a Fazenda possui o prazo de 5 (cinco) anos contados da constituição definitiva do crédito tributário para ajuizar a competente ação de cobrança, que se dá por meio da execução fiscal (art. 174, caput, do CTN). Esse prazo, porém, pode ser interrompido em algumas situações. Caso isso ocorra, reinicia-se o prazo quinquenal para a propositura do executivo fiscal (art. 174, § único, do CTN).

\footnotetext{
${ }^{490}$ Nesse sentido, já houve manifestação do Egrégio STF no RE no 559.882-9/RS (DJe 14 nov. 2008. Disponível em: <http://www.stf.jus.br/portal/jurisprudencia $>$. Acesso em: 2 fev. 2013); RE n ${ }^{0} 560.626-1 / \mathrm{RS}$ (DJe 05 dez. 2008. Disponível em: <http://www.stf.jus.br/portal/jurisprudencia $>$. Acesso em: 2 fev. 2013) e RE 556.664-1/RS (DJe 14 nov. 2008. Disponível em: <http://www.stf.jus.br/portal/jurisprudencia $>$. Acesso em: 2 fev. 2013), declarando a inconstitucionalidade do parágrafo único, do art. $5^{\circ}$, do Decreto-Lei ${ }^{\circ}$ 1.569/77, que estabelecia a suspensão da prescrição da cobrança de créditos tributários de pequeno valor. Esse precedente deu origem à edição da SV $\mathrm{n}^{0} 8$ do STF, com o seguinte teor "São inconstitucionais o parágrafo único do artigo $5^{\circ}$ do Decreto-Lei ${ }^{\circ} 1.569 / 1977$ e os artigos 45 e 46 da Lei ${ }^{\circ} 8.212 / 1991$, que tratam de prescrição e decadência de crédito tributário" (Disponível em: <http://www.stf.jus.br /portal/cms/verTexto.asp?servico=jurisprudenciaSumulaVinculante>. Acesso em: 2 fev. 2013).
} 
As hipóteses de interrupção da prescrição geralmente decorrem de um ato do sujeito ativo que manifesta seu interesse em receber os valores que lhe são devidos ${ }^{491}$. É o caso, por exemplo, da propositura da ação executiva e, consequentemente, do despacho do juiz que ordena a citação, do protesto judicial ou outro ato apto a constituir o devedor em mora (art. 174, I a III, do CTN). Mas não é só. Existe ainda a possibilidade de interrupção da prescrição por ato de iniciativa do devedor (art. 174, IV, do CTN).

A inclusão da admissão da proposta de transação entre as hipóteses de interrupção da prescrição parece correta. É que, quando o sujeito passivo apresenta a proposta de transação, ele manifesta sua intenção de pagar o tributo. Por outro lado, quando a autoridade competente admite a proposta efetuada, ela, por sua vez, também manifesta interesse em recuperar seu crédito, ainda que venha a efetuar alguma concessão para tanto, abrindo mão de parcela do crédito.

Poder-se-ia pensar em postergar esse efeito para quando da efetiva conclusão do termo de transação, momento em que a parte efetivamente reconhece a dívida, comprometendo-se a pagá-la na maneira acordada, da mesma forma em que ocorre com o parcelamento ${ }^{492}$. Porém, se assim o fizesse, ter-se-ia uma situação em que, durante o prazo para a conclusão do procedimento de transação, estaria correndo o prazo prescricional. Trata-se de uma questão de lógica e coerência. Por força do princípio da actio nata, não se poderia cogitar de penalizar a Fazenda pela sua suposta inércia se não era possível cobrar o crédito tributário que se encontrava com a exigibilidade suspensa.

Dessa forma, parece correto que a admissão da proposta de transação tenha por efeito a interrupção do prazo de prescrição para a Fazenda cobrar o crédito tributário. Quanto mais que esse dispositivo seria acrescido por meio de projeto de lei complementar, que altera as causas de interrupção da prescrição previstas no CTN, acrescentando uma nova hipótese de causa interruptiva ao art. 174 daquele diploma legal.

Além do mais, a admissão da proposta de transação tem também por efeito dar início ao prazo de cento e oitenta dias para a conclusão do conflito ou litígio. Quer

\footnotetext{
${ }^{491}$ SABBAG, Eduardo de Moraes. Manual de Direito Tributário. São Paulo: Saraiva, 2013, p. 828.

${ }^{492}$ A adesão ao parcelamento de débito tributários é considerada como causa de interrupção da prescrição. Nesse sentido é a Súmula $n^{\circ} 248$ do antigo TFR, segundo a qual: "O prazo da prescrição interrompido pela confissão e parcelamento da dívida fiscal recomeça a fluir no dia que o devedor deixa de cumprir o acordo celebrado". Também nesse mesmo sentido vários são os julgados do STJ, podendo-se destacar, a título exemplificativo, o Resp n ${ }^{\text {o }}$ 929.862/RS (DJe 03.09.2007). Disponível em: <http://www.stj.jus.br/SCON/ jurisprudencia/doc.jsp?livre $=929862 \& \& b=A C O R \& p=t r u e \& t=\& l=10 \& i=7>$. Acesso em: 2 fev. 2013; e o Resp $\mathrm{n}^{\mathrm{o}}$ 1.074.000/RS (DJe 12.12.2008). Disponível em: <http://www.stj.jus.br/SCON/jurisprudencia /doc.jsp?livre $=1074000 \& \& b=A C O R \& p=$ true $\& t=\& l=10 \& i=3>$. Acesso em: 2 fev. 2013.
} 
dizer, serve de marco temporal para o início da contagem do prazo limite para a conclusão do conflito ou litígio (art. 21, caput). Esse prazo não se suspende nem se interrompe, mas há possibilidade de sua prorrogação por mais cento e oitenta dias, mediante decisão motivada da autoridade competente (art. 21, $\S 1^{\circ}$ ). Tem-se, com efeito, que o prazo máximo para a solução seja, de fato, de trezentos e sessenta dias.

Decorrido o prazo para a solução do conflito ou litígio e conclusão do procedimento transacional sem que as partes tenham chegado a um acordo, o crédito tributário, que se encontrava suspenso, tornar-se-á novamente exigível, sendo cobrado no seu valor originário, com seus acréscimos legais. Nessa hipótese, desconta-se o montante pago durante o procedimento transacional, prosseguindo-se na cobrança do crédito remanescente, sem as reduções decorrentes da transação (art. 21, § $2^{\circ} \mathrm{c} / \mathrm{c}$ art. 14, caput).

Havendo decurso do prazo limite sem que as partes cheguem a uma solução para o conflito, parece também se aplicar a vedação a que uma outra proposta de transação venha a ser apresentada (art. 16, § único). É que, o objetivo desse dispositivo parece ter sido o de incentivar as partes a chegarem a um acordo dentro do prazo estabelecido, sob pena de restabelecer a situação conflituosa anterior. Nesse contexto, permitir que se venha a apresentar uma nova proposta poderia acabar por incentivar o contribuinte a postergar a conclusão do procedimento transacional. Isso faria com que se beneficiasse dos efeitos da admissão da proposta durante todo o procedimento até o decurso de seu prazo limite e, posteriormente, viesse a se beneficiar novamente de tal situação após a apresentação (e admissão) de nova proposta de transação.

Situação diversa, entretanto, é aquela em que o procedimento transacional não se concluiu dentro do prazo limite, em razão de culpa do órgão administrativo competente para analisar a proposta de transação. É que, como é sabido, a deficiência estrutural e de pessoal pode vir a retardar a análise da proposta pela autoridade competente. Nessa hipótese, embora o PL silencie a respeito, provada que a demora em tal análise se deu por culpa da Administração, o mais razoável parece ser que os efeitos da admissão da proposta sejam mantidos ou que se permita que o contribuinte apresente novamente tal proposta. Do contrário, a transação tributária, que teria por finalidade reduzir a litigiosidade, iria aumentá-la: a parte interessada que se sentisse prejudicada, certamente, proporia medidas judiciais para assegurar tais direitos até apreciação de sua proposta.

Em síntese, a admissão da proposta de transação pela autoridade competente 
acarreta os seguintes efeitos: (a) a suspensão da exigibilidade do crédito tributário; (b) a suspensão do processo administrativo ou judicial; (c) a interrupção da prescrição para a cobrança dos créditos tributários; e (d) o início do curso do prazo de cento e oitenta dias para a conclusão do procedimento de transação.

\subsubsection{Da celebração da transação e assinatura do respectivo termo}

Conforme se verá a seguir em mais detalhes, embora o PL não tenha atribuído o efeito de extinção do crédito tributário à celebração da transação e assinatura do respectivo termo, postergando-o para quando do cumprimento integral das obrigações e condições pactuadas (art. $\left.23, \S 3^{\circ}, \mathrm{I}\right)^{493}$, dispôs que a celebração da transação e assinautra do termo surtem, de imediato, alguns efeitos jurídicos.

Um dos efeitos da celebração da transação e assinatura do termo é o de excluir o impedimento para obtenção de certidão positiva com efeito de negativa (art. $23, \S 3^{\circ}$, IV). Em outras palavras, a celebração da transação possibilita a obtenção de certidão de regularidade fiscal. Note-se que isso já era possível a partir da admissão da proposta de transação (art. 20, § 2 , III). Tem-se, assim, a manutenção da autorização para que a Fazenda emita certidão de regularidade fiscal nos termos do art. 206 do CTN.

O art. 206 do CTN dispõe ter os mesmos efeitos da certidão negativa aquela de que conste a existência de créditos em cobrança, nas situações: (a) em que tenha sido efetivada a penhora, ou (b) cuja exigibilidade esteja suspensa. E, conforme já visto, o PLC $\mathrm{n}^{\circ} 469 / 2009$ altera o disposto no art. 151 do CTN, para prever que a admissão da proposta de transação suspende a exigibilidade do crédito tributário. Assim, apesar do PL silenciar quanto à extensão da suspensão da exigibilidade quando da celebração da transação, por uma questão de coerência, tem-se que esse efeito deve ser mantido após a assinatura de seu termo pelas partes envolvidas.

A obtenção da certidão de regularidade fiscal na hipótese de celebração da transação e assinatura de seu respectivo termo não é um direito absoluto do sujeito passivo. É que, o próprio dispositivo ressalva a hipótese em que haja disposição expressa em contrário no termo de transação (art. 23, § $3^{\circ}$, IV, in fine). Quer dizer, poderá haver situações em que seja conveniente para o interesse público restringir tal efeito: é o caso, por exemplo, da má-fé do sujeito passivo observada em outras oportunidades (e.g.

$\overline{493}$ Para uma análise mais detalhada dessa questão, conferir item 4.4.4 deste trabalho. 
descumprimento reiterado de parcelamentos anteriores).

Finalmente, deve-se ressaltar outras duas observações em relação à possibilidade de obtenção de certidão de regularidade fiscal quando da celebração da transação: (a) uma, é que o débito que estará suspenso e não será óbice à emissão de certidão será somente aquele objeto do termo de transação; havendo outros, nada obsta que o fisco recuse tal certidão; (b) outra, é que não há que se falar nesse efeito quando houver processo em curso para a anulação ou revogação do termo de transação; nessa hipótese, eventual certidão emitida será revogada (art. $23, \S 3^{\circ}, \mathrm{IV}$, “a” e "b").

Outro efeito da celebração da transação e assinatura do respectivo termo é a autorização para substituição da certidão de dívida ativa, sem ônus para a Fazenda Nacional (art. 23, $\S 3^{\circ}$, III). Embora o dispositivo não determine imperativamente que tem que ocorrer, mas tão somente autorize que venha a ocorrer, quando e se houver necessidade, não se vislumbra, na prática, hipótese em que seria necessária a referida substituição nessa etapa do procedimento de transação.

A substituição da certidão dívida ativa é prática comum da Fazenda nas execuções fiscais. Constatando, de ofício ou a requerimento do interessado, algum equívoco na certidão da dívida ativa, $\mathrm{o}$ art. $2^{\circ}, \S 8^{\circ}$, da Lei $n^{\circ} 6.830 / 80$ permite que a Fazenda promova sua emenda ou substituição nos respectivos autos judiciais. Ressalta, porém, que tal conduta somente pode ocorrer até a decisão de primeira instância e desde que assegurado a devolução do prazo para embargos ao executado ${ }^{494}$.

No entanto, no caso da celebração da transação e assinatura do respectivo termo pelas partes envolvidas, não parece necessária (nem conveniente) a substituição da certidão da dívida ativa nesse momento. É que, conforme já antecipado, a extinção do crédito tributário não ocorre nessa fase do procedimento transacional, mas tão somente quando do cumprimento integral das obrigações e condições pactuadas no respectivo termo de transação (art. $\left.23, \S 3^{\circ}, \mathrm{I}\right)$.

Note-se que, poderão existir situações em que, após concluída a transação e assinado o seu termo, o sujeito passivo venha a descumprí-lo. Tal descumprimento autoriza a revogação dos compromissos pactuados (art. 13, II) e o restabelecimento do

\footnotetext{
${ }^{494}$ Sobre a possibilidade de substituição da certidão da dívida ativa pela Fazenda Pública e seus limites, editou-se a Súmula do STJ n ${ }^{\circ}$ 392, que dispõe que: "A Fazenda Pública pode substituir a cerdidão de dívida ativa (CDA) até a prolação da sentença de embargos, quando se tratar de correção de erro material ou formal, vedada a modificação do sujeito passivo da execução". Disponível em <http://www.stj.jus.br $/ \mathrm{SCON} /$ sumulas/doc.jsp?livre=\%40docn\&\&b=SUMU\&p=true $\& \mathrm{t}=\& \mathrm{l}=10 \& \mathrm{i}=108>$. Acesso em: 2 fev. 2013.
} 
crédito em seu valor originário (art. 14, caput) ${ }^{495}$. Assim, parece mais conveniente que a substituição da certidão ocorra somente quando houver o cumprimento integral das obrigações; do contrário, a Fazenda terá trabalho dobrado, fazendo-o: quando da assinatura do termo de transação e, novamente, quando de seu eventual descumprimento.

Um outro efeito que se atribui à celebração da transação e assinatura do respectivo termo é a renúncia pelo sujeito passivo a eventuais questões deduzidas em relação ao crédito tributário objeto da transação. Em realidade, trata-se de renúncia não somente em relação às eventuais medidas administrativas e judiciais cabíveis de que disponha a parte para a defesa de seu direito, como também em relação ao próprio direito, em si, que a parte tenha em relação ao crédito objeto da transação.

Talvez por excesso de zelo, o PL contemplou tal renúncia duas vezes: (a) uma, ao que parece, como efeito direto da celebração da transação, determinando que a transação implica em renúncia ao direito sobre que se funda a ação ou recurso, seja ele administrativo ou judicial, no que tange às questões objeto do termo de transação (art. 11, caput); e (b) outra, como requisito obrigatório do termo de transação, estabelecendo que deverá constar, como cláusula do acordo, a renúncia expressa do sujeito passivo aos direitos relativos ao objeto da transação, incluido o direito de promover qualquer medida judicial ou administrativa (art. 24, VI, “c”).

A renúncia ao direito sobre que se funda a ação é colocada normalmente, também, como condição para adesão do contribuinte aos programas de parcelamento de débitos ${ }^{496}$. Seu objetivo, tanto lá quanto cá, é impedir que, uma vez celebrado o acordo, possa o sujeito passivo continuar questionando, ou vir futuramente a questionar, administrativa ou judicialmente, algum aspecto do crédito tributário objeto do acordo. Assim, por exemplo, no caso da transação, havendo medida administrativa ou judicial em curso, impugnando algum aspecto do crédito tributário (e.g. embargos à execução fiscal), e sobrevindo a transação e assinatura de seu respectivo termo, tem-se a extinção dos referidos embargos com resolução de mérito, por força do disposto no art. 269, V, do CPC.

Poderia vir a se questionar a necessidade de se atribuir um tal efeito à celebração da transação e assinatura do termo, na medida em que o art. 269, III, do CPC prevê expressamente que haverá a extinção do processo com resolução de mérito "quando as

\footnotetext{
495 As situações que permitem a revogação do termo de transação e suas consequências serão analisadas em mais detalhes no item 4.5 deste trabalho.

${ }^{496}$ É o caso, por exemplo, do art. $6^{\circ}$, da Lei n ${ }^{\circ} 11.941 / 09$, bem como do art. $4^{\circ}$, II da Lei no ${ }^{\circ} 10.684 / 03$.
} 
partes transigirem". Parece, entretanto, que a renúncia ao direito como efeito da celebração da transação não é sem razão. Tem ela importância notadamente nas situações em que houver o descumprimento das condições pactuadas na transação e for revogado o seu termo. É que, nessa hipótese, poderia o sujeito passivo alegar que a transação não se aperfeiçoou, não lhe sendo aplicável o disposto no art. 269, III, do CPC. E, assim, retomaria as discussões em relação ao crédito objeto da transação. Não poderá, no entanto, valer-se desse argumento na hipótese de transação. O PL optou por ser prudente, determinando que a celebração da transação per se implica em renúncia a eventuais questões deduzidas em relação ao crédito tributário objeto da transação (art. 11, caput), bem como que o descumprimento de seu termo não a afasta (art. 13, § único).

Finalmente, um outro efeito da celeberação da transação e assinatura do respectivo termo previsto no PL é a suspensão de eventuais processos de execução fiscal correspondentes aos débitos transigidos e o arquivamento dos respectivos autos sem baixa na distribuição até que sejam pagos integralmente os montantes acordados $\left(\operatorname{art} .28, \S 1^{\circ}\right)$.

Conforme anteriormente analisado, a suspensão dos processos em que se discute o crédito tributário objeto da proposta de transação é efeito de sua admissão pela autoridade administrativa competente (art. 20, I e $\S 1^{\circ}$ ). Esse efeito, logicamente, aplica-se também ao processo de execução fiscal, que tem por objeto a cobrança do crédito em questão. Assim, a suspensão da execução fiscal sem baixa na distribuição após a celebração da transação nada mais é do que a manutenção desse efeito.

Trata-se de consequência lógica que decorre do princípio da eficiência e economia processual. Da mesma forma em que a admissão da proposta de transação suspende os processos em que se discute o crédito tributário objeto da referida proposta, impedindo sua cobrança, com muito mais razão essa cobrança deverá permanecer suspensa quando celebrada a transação e assinado o seu respectivo termo. Ao menos, enquanto o sujeito passivo estiver adimplindo as obrigações pactuadas no respectivo termo.

Todavia, diferentemente do disposto no PL de que a suspensão deveria se dar até que pagos integralmente os montantes acordados, parece que o mais adequado seja que a suspensão ocorra até o adimplemento total das obrigações. É que, conforme visto, podem existir obrigações outras além do pagamento (e.g. manutuenção da atividade empresarial por 3 anos, nas hipóteses de transação por recuperação tributária - art. 37, X; manutenção da regularidade fiscal com relação a todos os tributos federais por 5 anos subsequentes à 
celebração da transação, nas hipóteses de transação por insolvência civil, falência ou recuperação judicial - art. 33). Pelo princípio da economia processual, nessas situações, o mais correto é que a suspensão do processo se dê até o cumprimento dessas obrigações.

Em síntese, a celebração da transação e assinatura de seu respectivo termo acarreta os seguintes efeitos: (a) permissão para obtenção de certidão positiva de débitos com efeito de negativa; (b) autorização para, quando necessário, substituir a certidão da dívida ativa; (c) renúncia pelo sujeito passivo a eventuais questões deduzidas em relação ao crédito tributário objeto da transação; e (d) suspensão da execução fiscal correspondente aos débitos transigidos e o arquivamento dos autos sem baixa na distribuição.

\subsubsection{Do cumprimento das condições e obrigações pactuadas}

O principal efeito do cumprimento das obrigações e condições pactuadas no termo de transação é a extinção do crédito tributário. O efetivo momento em que o crédito se extingue na hipótese da transação tributária é matéria bastante controvertida na doutrina $^{497}$. Possivelmente para evitar discussões a esse respeito, o PL optou por atribuir o efeito extintivo do crédito somente quando efetivada essa etapa do procedimento transacional. Dispôs que a transação é ato jurídico que se aperfeiçoa e extingue o crédito tributário após o cumprimento integral das obrigações e condições pactuadas nas cláusulas do seu respectivo termo (art. 23, $\S 3^{\circ}$, I). Esse dispositivo encontra respaldo jurídico na alteração do art. 156, III, do CTN pelo PLC n 469/2009, que dispõe ser "o cumprimento do termo de transação” que extingue o crédito tributário.

Com efeito, na forma em que redigido o projeto, a mera celebração da transação e assinatura do respectivo termo não tem per se o condão de extinguir o crédito tributário. No entanto, poder-se-ia sustentar que a parcela do crédito a que as partes abriram mão ao transacionar estaria extinta já a partir do momento da celebração da transação. Ainda que assim se entenda, a extinção dessa parte do crédito tributário ocorreria sob condição

\footnotetext{
${ }^{497}$ A título ilustrativo dessa controvérsia, Paulo de Barros Carvalho defende que a transação tão somente prepara o caminho para que o sujeito passivo quite sua dívida, sustentando que a extinção efetiva da obrigação na transação somente ocorre quando do pagamento (CARVALHO, Paulo de Barros. Curso de Direito Tributário. São Paulo: Saraiva, 2012, p. 540). Nesse mesmo sentido parece ser o posicionamento de Heleno Taveira Tôrres, para quem é o pagamento que extinguirá o crédito, não a transação pura e simples. (TÔRRES, Heleno Taveira. Princípio da segurança jurídica e transação em matéria tributária. Os limites da revisão administrativa dos acordos tributários. In: SARAIVA FILHO, Oswaldo Othon de Pontes; GUIMARÃES, Vasco Branco (Org.). Transação e Arbitragem no Âmbito Tributário. Belo Horizonte: Fórum, 2008, p. 305). Em sentido oposto parece ser o posicionamento de Luís Eduardo Schoueri, segundo o qual, a transação implica novação, extinguindo o crédito tributário e fazendo surgir um novo crédito, resultado da transação (SCHOUERI, Luís Eduardo. Direito Tributário. São Paulo: Saraiva, 2013, p. 624).
} 
resolutória. É que, sobrevindo o descumprimento das condições pactuadas, o crédito será cobrado em seu valor originário, com seus acréscimos (art. 14, caput $)^{498}$.

Um segundo efeito do cumprimento das condições e obrigações pactuadas no termo de transação é a extinção das execuções fiscais correspondentes aos créditos transigidos (art. 28, $\S 1^{\circ}$, in fine). Esse efeito, é uma decorrência lógica da própria extinção do crédito tributário: se o crédito tributário, consubstanciado na certidão de dívida ativa, que serve de título executivo para embasar a ação de execução fiscal, é extinto, não há como se prosseguir com a cobrança desse crédito, nem razão para manterem-se as execuções físcais suspensas e os autos arquivados sem baixa na distribuição ${ }^{499}$.

Embora o PL somente se refira a esse efeito em relação às execuções físcais, parece que o mesmo se aplica a eventuais outras ações em curso em que se discuta o crédito tributário objeto da transação. Note que grande parte das medidas administrativas ou judiciais interpostas pelo sujeito passivo deverão ser extintas quando da assinatura do respectivo termo, por força do efeito da renúncia a eventuais questões deduzidas em relação ao crédito tributário objeto da transação (art. 11, caput). Aquelas que, eventualmente, ainda não estiverem (e.g. cautelar fiscal), deverão ser extintas quando do cumprimento das obrigações e condições pactuadas no termo de transação.

Finalmente, o cumprimento integral das obrigações e condições pactuadas implica também na extinção da pretensão punitiva estatal em relação aos crimes contra ordem tributária, aos crimes de apropriação indébita previdenciária e aos crimes de sonegação de contribuição previdenciária. Assim, a punibilidade que se encontrava suspensa a partir da apresentação da proposta de transação pelo sujeito passivo deverá ser definitivamente extinta pelo cumprimento das obrigações pactuadas e pagamento do crédito tributário.

Note, porém, que o PL dispôs extinguir-se a punibilidade dos referidos crimes quando a pessoa jurídica relacionada com o agente do crime efetuar o pagamento integral dos débitos oriundos de tributos e contribuições sociais, inclusive acessórios (art. 54, § $\left.2^{\circ}\right)$. Assim, parece que, para fins penais, basta o pagamento do crédito tributário, sendo desnecessário o cumprimento das demais condições e obrigações pactuadas no termo de

\footnotetext{
498 Sobre as consequências do descumprimento das obrigações e condições pactuadas no termo de transação, conferir item 4.5 deste trabalho.

${ }^{499}$ Sobre a suspensão das execuções fiscais e arquivamento dos autos sem baixa na distribuição como efeito da celebração da transação e assinatura de seu respectivo termo, conferir item 4.4.3 deste trabalho.
} 
transação. Ao menos, é isso que se deduz da redação do dispositivo em questão.

Ademais, tendo a transação implicado em redução dos acessórios, ou mesmo do tributo nas hipóteses especificadas no art. $7^{\circ}, \S 1^{\circ}$ do PL, parece que o pagamento integral a que se refere o dispositivo é aquele resultante do termo de transação, com as reduções legais, e não o pagamento do valor originário do débito; isso, evidentemente, se houver o cumprimento das obrigações pactuadas; não havendo, aí sim, somente o pagamento do valor originário terá por efeito a extinção da punibilidade nos referidos crimes.

Em síntese, o adimplemento total das obrigações e cumprimento das condições pactuadas no termo de transação implica: (a) extinção do crédito tributário; (b) extinção da execução físcal ou do processo em que se discutia a matéria objeto da transação; e (c) extinção da pretensão punitiva; nessa última hipótese, parece que o pagamento já seria suficiente para tanto, sendo desnecessário o cumprimento das demais condições, salvo para fazer jus a esse efeito com os benefícios e reduções pactuados.

A partir desse momento, o ato jurídico formalizado pelo termo de transação considera-se perfeito e acabado, não podendo mais vir a ser discutido nem alterado $^{500}$.

\subsection{Hipóteses de revogação, nulidade e revisão do termo de transação e suas consequências}

Um dos principais objetivos da transação em matéria tributária é resolver conflitos tributários. Por meio dela, coloca-se fim a eventual litígio existente entre as partes. Esses litígios poderiam ser (e normalmente são) resolvidos pelo Poder Judiciário, mas em razão dos inconvenientes relacionados a essa forma tradicional de resolução de conflitos, tem-se privilegiado soluções alternativas. $\mathrm{O}$ excesso de demandas naquela esfera e o alto custo inerente a um processo judicial, aliado à demora em se obter uma decisão judicial definitiva, impõem um meio de solução de controvérsias mais rápido e, sobretudo, com a participação do contribuinte no processo decisório: a transação tributária.

A pacificação do conflito e consequente extinção do crédito tributário garante aos contribuintes uma maior certeza e segurança nas suas relações jurídicas. Demais disso, serve para dar maior previsibilidade às condutas estatais ${ }^{501}$. A extinção do crédito, no entanto, somente ocorrerá após o cumprimento integral das condições e obrigações pactuadas no termo de transação. É que, conforme visto oportunamente, somente nesse

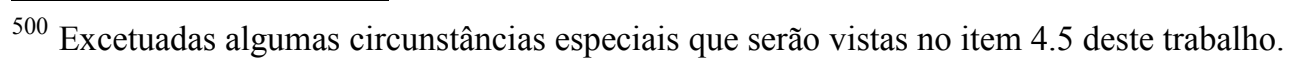


momento é que a transação se aperfeiçoa e o crédito tributário é efetivamente extinto (art. $\left.23, \S 3^{\circ}, I\right)^{502}$. Assim, somente quando do cumprimento integral das condições pactuadas é que a transação torna-se perfeita e acabada, não podendo mais ser alterada.

Entretanto, podem ocorrer hipóteses em que, mesmo após a celebração da transação e assinatura do respectivo termo, as condições e obrigações pactuadas não sejam cumpridas pela parte. Nessa situação, o PL autoriza a revogação dos compromissos acordados, após a notificação do sujeito passivo para se manifestar no prazo de quinze dias (art. 13, II $)^{503}$. A necessidade de notificação prévia do sujeito passivo decorre da garantia constitucional ao contraditório e ampla defesa ${ }^{504}$. Da redação do dispositivo, depreende-se que a revogação dos compromissos pactuados é uma faculdade, podendo haver situações em que seja mais conveniente ao interesse público manter aquilo que foi anteriormente acordado entre as partes.

Note que a revogação dos compromissos acordados no termo de transação não afasta a renúncia pelo sujeito passivo ao direito sobre que se funda a ação ou recurso, administrativo ou judicial, no que tange à matéria objeto da transação. Este efeito, que decorre da celebração da transação e assinatura do respectivo termo, permanecerá ainda que revogados os compromissos assumidos (art. 13, § único). Seu objetivo é justamente evitar a rediscussão das matérias nas situações em que houver o descumprimento das condições pactuadas na transação e for revogado o seu termo ${ }^{505}$.

Além disso, o descumprimento das obrigações relativas ao termo de transação implica também em interrupção da prescrição (art. 13, I). Tratando-se a prescrição de norma geral em matéria de legislação tributária, essa hipótese encontra-se contemplada também no PLC no 469/2009, que tem natureza de lei complementar. Esse normativo introduz algumas novas causas de interrupção da prescrição. Nesse sentido, acrescenta às causas atuais de interrupção da prescrição do art. 174, § único, do CTN, “o descumprimento das obrigações constantes do termo de transação ou do laudo arbitral".

\footnotetext{
${ }^{501}$ TÔRRES, Heleno Taveira. Princípio da segurança jurídica e transação em matéria tributária. Os limites da revisão administrativa dos acordos tributários. In: SARAIVA FILHO, Oswaldo Othon de Pontes; GUIMARÃES, Vasco Branco (Org.). Transação e Arbitragem no Âmbito Tributário. Belo Horizonte: Fórum, 2008, p. 310.

${ }^{502}$ A esse respeito, conferir item 4.4.4. deste trabalho.

${ }^{503}$ Trata-se de uma espécie de exceção de inexecução do agrément previsto no Direito francês. Acerca do agrément, conferir item 1.3.2.2 deste trabalho.

504 JUNQUEIRA, Helena Marques Junqueira. Transação Tributária. Tese (Doutorado), Faculdade de Direito da Pontifícia Universidade Católica de São Paulo, 2009, p. 221.

${ }^{505}$ A esse respeito, conferir item 4.4.3. deste trabalho.
} 
Importante salientar que na hipótese de revogação do termo de transação, o crédito tributário será exigido em seu valor originário, sem as reduções decorrentes da transação, descontando-se o montante pago no período e prosseguindo-se na cobrança ou na execução do crédito tributário remanescente (art. 14, caput). Ademais, eventual certidão de regularidade fiscal será cancelada (art. 14, § único). Enfím, o descumprimento das condições e obrigações pactuadas na transação (ainda que não se opte pela revogação de seu termo) implica na aplicação de multa de vinte por cento sobre o valor do débito resultante da transação (art. $9^{\circ}$ ).

Viu-se até aqui as consequências do descumprimento das condições e obrigações pactuadas no termo de transação, que pode, eventualmente, acarretar a revogação do termo de transação. Entretanto, na hipótese de cumprimento integral das obrigações e condições pactuadas, ter-se-á o aperfeiçoamento da transação e a extinção do crédito tributário objeto de seu respectivo termo. Nessa situação, tem-se que o crédito objeto da transação não poderá mais ser questionado. Heleno Taveira Tôrres destaca que, nesse caso, a transação estará protegida constitucionalmente como ato jurídico perfeito ${ }^{506}$.

O PL parece ter seguido esse entendimento. Dispôs que o termo de transação, em regra, não pode ser discutido administrativa ou judicialmente. Ressalvou, porém, uma situação específica em que se admite a discussão do termo de transação: nas hipóteses de sua nulidade (art. 12, caput). Entre as hipóteses que ensejam a nulidade da transação e seu termo, encontram-se aquelas em que se constatar: a ausência de condições e requisitos formais ou materiais; que a transação não poderia ter ocorrido em razão de vedação legal; que já houve sentença judicial transitada em julgado resolvendo o litígio; que houve prevaricação, concussão ou corrupção passiva; que ocorreu dolo, fraude, simulação, erro essencial quanto à pessoa ou quanto ao objeto do conflito (art. 12, I a IV $)^{507}$.

Para evitar alegações infundadas de nulidade, o PL previu que qualquer alegação que não se faça nos limites da demonstração da nulidade será considerada como litigância de má-fé, excetuados os litígios decorrentes da incorreta aplicação dos critérios previstos no termo (art. $12, \S 3^{\circ}$ ). Tal conduta será punível com multa de $1 \%$ sobre o valor da causa,

\footnotetext{
506 TÔRRES, Heleno Taveira. Princípio da segurança jurídica e transação em matéria tributária. Os limites da revisão administrativa dos acordos tributários. In: SARAIVA FILHO, Oswaldo Othon de Pontes; GUIMARÃES, Vasco Branco (Org.). Transação e Arbitragem no Âmbito Tributário. Belo Horizonte: Fórum, 2008, p. 310.

${ }^{507}$ Nesse aspecto, assemelha-se, em parte, aos closing agreements do Direito norte-americano, que prevê a possibilidade de modificação nas hipóteses de fraude, prevaricação ou quando a matéria fática apresentada pelo contribuinte for inexata. A esse respeito, conferir item 1.4.1.3 deste trabalho.
} 
além de indenização pelos prejuízos sofridos pela parte adversa, honorários advocatícios e outras despesas (art. 17 e 18, do CPC) ${ }^{508}$. Ademais, o PL dispôs também que a transação não se anula por erro de direito referente às questões objeto da solução de controvérsia (art. 12, § $5^{\circ}$ ). Quer dizer, veda-se que um equívoco na interpretação da legislação aplicável ao caso sirva de fundamento para a posterior anulação da transação.

Em relação ao órgão competente para a declaração de eventual nulidade da transação, tem-se ser possível sua decretação: (a) administrativamente - a requerimento do sujeito passivo, ou de ofício pela CGTC ou órgão administrativo com competência delegada, hipótese em que deverá ser precedida de notificação para o sujeito passivo se manifestar no prazo de quinze dias; e (b) judicialmente - pelo juízo competente que houver homologado a transação, mediante pedido da Fazenda Nacional ou do sujeito passivo (art. 12, $\S 2^{\circ}$, I e II). Limitou a hipótese de reconhecimento judicial da nulidade às transações homologadas pelo juízo; em outras palavras, limitou essa forma de reconhecimento de nulidade à modalidade de transação em processo judicial. Tal restrição parece discutível, pois que não haveria impedimento a que o sujeito passivo pudesse propor medida judicial exigindo o reconhecimento judicial da nulidade da transação, quando diante de uma das situações abrangidas pela lei ${ }^{509}$.

Frise-se que na hipótese de nulidade do termo de transação, assim como ocorre na revogação de seu termo, o crédito tributário também será exigido em seu valor originário, sem as reduções decorrentes da transação, descontando-se o montante pago no período e prosseguindo-se na cobrança ou na execução do crédito tributário remanescente (art. 14, caput). Ademais, eventual certidão de regularidade fiscal obtida será cancelada (art. 14, § único). No entanto, diferentemente do que ocorre quando do descumprimento das condições e obrigações pactuadas na transação, eventual nulidade não implica aplicação de multa de vinte por cento sobre o valor do débito resultante da transação $\left(\operatorname{art.} 9^{\circ}\right)$.

A limitação das situações que dão ensejo à rediscussão da matéria objeto da transação visa a garantir segurança jurídica às partes envolvidas. De nada adiantaria a transação como método de solução de litígios se as matérias objeto da transação pudessem ser posteriormente rediscutidas perante o Poder Judiciário. Essa limitação tem, portanto,

\footnotetext{
${ }^{508}$ GODOY, Arnaldo Sampaio de Moraes. Transação Tributária: introdução à justiça fiscal consensual. Belo Horizonte: Fórum, 2010, p. 142.

509 JUNQUEIRA, Helena Marques Junqueira. Transação Tributária. Tese (Doutorado), Faculdade de Direito da Pontifícia Universidade Católica de São Paulo, 2009, p. 212.
} 
um caráter dúplice: de um lado, objetiva desestimular que os sujeitos passivos insatisfeitos com o conteúdo dos acordos celebrados venham a rediscutir a questão na esfera judicial, o que aumentaria a litigiosidade, ao invés de diminuí-la; de outro, evitar que a Administração tributária pudesse retratar-se das concessões efetuadas, anulando ou revendo o termo de transação pactuado com o sujeito passivo ${ }^{510}$.

Entretanto, o PL admitiu a revisão do termo de transação pela autoridade competente em algumas situações específicas. Tal revisão teria efeito ex nunc; quer dizer, efeitos prospectivos que somente se aplicariam daí para frente. Estabeleceu-se como pressuposto para a revisão administrativa do termo de transação a prévia notificação do sujeito passivo, permitindo, assim, que ele se manifeste no prazo de quinze dias (art. 12, § $\left.6^{\circ}\right)$. As hipóteses que fundamentam essa revisão são bastante limitadas, podendo ocorrer quando o termo de transação tiver se fundado: em lei ou ato normativo declarados inconstitucionais pelo STF; ou na aplicação ou interpretação da lei ou ato normativo contrário à jurisprudência dos tribunais superiores e do STF (art. 12, § $6^{\circ}$, I e II).

Helena Marques Junqueira faz contundente crítica a esses dispositivos, que mitigam a impossibilidade de discussão administrativa ou judicial do termo de transação, para além das situações de nulidade. É que, no entender da autora, seria inaceitável que esses fatos supervenientes à transação poudessem vir a alterar o conteúdo do acordo celebrado entre fisco e sujeito passivo, que se aperfeiçoou quando do cumprimento das obrigações pactuadas em seu termo. Entende que tais dispositivos, caso venham a ser aprovados, darão ensejo à enorme insegurança, pois que um conflito que já se encontrava resolvido poderá ressurgir a partir da revisão do termo de transação ${ }^{511}$.

Embora totalmente compreensível a preocupação da autora, notadamente em relação ao impacto dessa revisão na segurança jurídica e na confiança legítima do sujeito passivo, tal crítica merece ser atenuada. Isso porque, ao que parece, o que se quis com esse dispositivo foi assegurar à transação, quando perfeita e acabada, o mesmo tratamento que é dado às decisões judiciais transitadas em julgado. Note que, em relação a estas, não obstante a proteção assegurada à coisa julgada pelo ordenamento jurídico pátrio, vem-se admitindo, em algumas situações, sua relativização. Um de seus requisitos é a alteração das circunstâncias fáticas ou jurídicas que fundamentaram a decisão judicial transitada em

510 JUNQUEIRA, Helena Marques Junqueira. Transação Tributária. Tese (Doutorado), Faculdade de Direito da Pontifícia Universidade Católica de São Paulo, 2009, p. 211.

511 Ibid., p. 213. 
julgado. E, embora discutível, inclui-se, entre as situações que legitimam a relativização da coisa julgada, a consolidação da jurisprudência do STF em sentido contrário à decisão transitada em julgado ${ }^{512}$. Tem-se, pois, que as hipóteses de revisão do termo de transação mencionadas no PL visam a permitir a "relativização da transação", de forma semelhante ao que ocorre com as decisões judiciais transitadas em julgado, em que se permite, evidentemente, em hipóteses excepcionais, a "relativização da coisa julgada"513.

\subsection{Críticas ao Projeto de Lei $n^{0}$ 5.082/2009 e propostas de aperfeiçoamento da legislação}

$\mathrm{Na}$ forma em que redigido atualmente, o referido Projeto de Lei merece alguns reparos para permitir seu aperfeiçoamento e facilitar a compreensão de seus dispositivos. Muitos desses reparos já foram analisados no decorrer desse capítulo: é o caso, por exemplo, da necessidade (a) de serem contemplados recursos nas hipóteses de inadmissão e decisão denegatória do requerimento de transação; (b) de serem explicitados os motivos pelos quais houve a diferenciação do marco temporal para a realização da transação, a depender da existência ou não de execução fiscal em curso; (c) de ser esclarecido qual o juízo compentente para apreciar o requerimento de transação na modalidade de transação por insolvência civil, falência ou recuperação judical; (d) de serem contemplados efeitos específicos na hipótese de não conclusão da transação dentro do prazo limite por culpa da Administração; e (e) de ser explicitado que a suspensão da exigibilidade do crédito é mantida quando da celebração da transação e assinatura do respectivo termo.

Outros, porém, serão analisados a seguir, restringindo essa análise a duas questões principais: a ampla discricionariedade de que dispõe o órgão competente para analisar e, eventualmente, autorizar as propostas de transação, bem como a ausência de efetiva independência funcional de seus membros (item 4.6.1); e a necessidade de assegurar maior transparência e publicidade às decisões proferidas no procedimento transacional (item 4.6.2). Tais alterações farão com que se evitem abusos por parte da autoridade administrativa, bem como privilégios a determinados contribuintes, além de facilitar o

\footnotetext{
${ }^{512}$ A esse respeito, conferir Parecer PGFN CRJ no $492 / 2011$.

513 Note que a questão da relativização da coisa julgada nas hipóteses de modificação do cenário jurisprudencial é bastante controvertida. Não se pretende, nesse trabalho, aprofundar-se nessa discussão, nem para defender, nem para criticá-la. O objetivo aqui é tão somente compreender as hipóteses de revisão do termo de transação admitidas no PL. Para uma análise de algumas das críticas em relação a esse tema, conferir SANTIAGO, Igor Mauler. A crise atual da coisa julagada em matéria tributária. Disponível em: $<$ http://sachacalmon.com.br/biblioteca/artigos/a-crise-atual-da-coisa-julgada-em-materia-tributaria $>$. Acesso em: 31 mar. 2013.
} 
controle da população e dos órgãos administrativos. Enfim, tais alterações são essenciais para que se assegure a igualdade de tratamento entre os contribuintes.

\subsubsection{Ampla discricionariedade da Câmara Geral de Transação e} Conciliação da Fazenda Nacional e ausência de efetiva independência funcional de seus membros

Conforme já visto, uma das grandes críticas feitas ao PL em trâmite no Congresso consiste no fato dele ter outorgado uma margem enorme de poderes, em relação à transação tributária, à CGTC, Câmara Geral de Transação e Conciliação da Fazenda Nacional. Esses poderes compreendem, entre outros: (a) a regulamentação do procedimento de transação, notadamente quanto aos requisitos, forma e parâmetros que devem observar as propostas de transação; (b) a admissão e análise de proposição que envolva interpretação de conceito jurídico indeterminado; e (c) a manifestação aprovando ou não as propostas de transação. Essa atribuição vasta de poderes à CGTC pode vir a gerar inúmeros problemas, conforme será visto a seguir.

A redação atual do PL estabelece um amplo poder normativo à CGTC. Conforme se depreende de seus dispositivos, este órgão terá poderes para regular o procedimento da transação, por meio de resoluções e regulamentos (e.g. art. $4^{\circ}$, caput c.c. art. 40, II e III). Como o projeto de lei não estabeleceu requisitos rígidos para a transação, a CGTC poderá, sob o argumento de regulamentar o instituto, impor requisitos e condições que não estejam na lei. Isso poderia restringir o acesso dos contribuintes à transação, o que seria questionável, pois que tal restrição estaria fundamentada em ato administrativo ${ }^{514}$.

Demais disso, conforme já visto, o PL permite que, excepcionalmente, a transação implique em redução de parte do tributo devido. Isso pode ocorrer, por exemplo, quando a redução decorra da interpretação de conceitos jurídicos indeterminados ${ }^{515}$. Nessa situação, atribuiu-se competência à CGTC para admissão e análise da proposta (art. $7^{\circ}, \S 1^{\circ}$ e $\left.\S 2^{\circ}\right)$. Tal competência dá uma margem de discricionariedade excessiva a este órgão para definir tais e quais conceitos jurídicos são, de fato, indeterminados e, consequentemente, podem

\footnotetext{
${ }^{514}$ A esse respeito, a Helena Marques Junqueira ressalta que: “[...] teria sido melhor que a própria lei estabelecesse de forma mais objetiva os parâmetros para que cada caso pudesse ou não ser objeto da transação tributária e não deixando questão tão importante para a esfera de normatização administrativa [...]". (JUNQUEIRA, Helena Marques. Transação Tributária. Tese (Doutorado em Direito), Faculdade de Direito da Pontifícia Universidade Católica de São Paulo, 2009, p. 156).

${ }^{515}$ A esse respeito, conferir item 4.2.2 deste trabalho.
} 
ser objeto de transação ${ }^{516}$. Apesar de encontrar-se, de certa forma, minimizada, pois que o entendimento da CGTC estará sujeito à homologação por turma especializada da Câmara Superior de Recursos Fiscais (art. $7^{\circ}, \S 2^{\circ}$, in fine), verifica-se que os poderes atribuídos à CGTC são excessivos, merecendo algum tipo de limitação pelo legislador.

Importante ressaltar que, na forma em que redigido, o PL dá também amplos poderes à CGTC para decidir se aceita ou não a proposta de transação ${ }^{517}$. Fica a critério da CGTC, ou de autoridade por ela designada, o juízo de conveniência e oportunidade para autorizar ou não a transação no caso concreto (art. $1^{\circ}$, $\S$ único; art. $19, \S 4^{\text {o }}$; e art. 47 , caput). É verdade que a avaliação da CGTC é discricionária e não arbitrária, estando condicionada ao atendimento do interesse público, devendo ainda suas decisões serem devidamente motivadas (art. 47, III), o que assegura um certo controle de suas decisões ${ }^{518}$. Porém, isso por si só não parece suficiente para impedir que se cometam abusos, privilegiando alguns contribuintes em detrimento de outros. Faz-se necessária a previsão no PL de um órgão de supervisão da atividade da CGTC, inclusive com poderes para julgar eventuais recursos dos contribuintes.

Some-se a isso o fato de que, em conformidade com o PL, a CGTC será composta paritariamente por Procuradores da Fazenda Nacional e Auditores-Fiscais da Receita Federal do Brasil, designados pelo Ministro da Fazenda (art. 49, caput), cuja permanência será limitada a quatro anos, prorrogáveis por mais quatro, uma única vez (art. $49, \S 2^{\circ}$ ). Apesar de haver previsão expressa de que seus membros gozam das prerrogativas de independência funcional e inamovibilidade e que deverão agir com imparcialidade (art. 52, caput), não existiria, de fato, garantia de verdadeira imparcialidade nem independência funcional de seus membros. É que, conforme destaca Simone Anacleto Lopes, os dispositivos que tratam do assunto não garantem um mandato fixo aos membros

\footnotetext{
${ }^{516}$ Nesse sentido, parece ser o posicionamento de Luís Eduardo Schoueri, manifestado durante mesa de debates do Instituto Brasileiro de Direito Tributário. Ata da Mesa de Debate do IBDT de 10 nov. 2011. Disponível em $<\mathrm{http} / / / \mathrm{www} . i b d t . c o m . b r / m a t e r i a l /$ arquivos/Atas/integra_10112011.pdf $>$. Acesso em $08 \mathrm{mar}$. 2013.

${ }^{517}$ MORAIS, Carlos Yuri Araújo. Transação e arbitragem em matéria tributária: a experiência estrangeira e sua aplicabilidade ao direito brasileiro. In: SARAIVA FILHO, Oswaldo Othon de Pontes; GUIMARÃES, Vasco Branco (Org.). Transação e Arbitragem no Âmbito Tributário. Belo Horizonte: Fórum, 2008, p. 409. Nesse sentido, em relação ao anteprojeto apresentado, o referido autor assim se manifestou: “[...] A redação atual afirma que ficará sempre a cargo da Câmara Geral de Conciliação da Fazenda Nacional (CGCFN), integrada à PGFN e, nas unidades regionais, às Câmaras de Conciliação da Fazenda Nacional (CCFN), a última palavra sobre o interesse da Fazenda em realizar os acordos e os parâmetros segundo os quais serão realizados. Porém, a outorga de uma ampla discricionariedade à Administração seguramente leverá a uma transgressão do princípio da igualdade".

518 JUNQUEIRA, Helena Marques. Transação Tributária. Tese (Doutorado em Direito), Faculdade de Direito da Pontifícia Universidade Católica de São Paulo, 2009, p. 205.
} 
da CGTC, tendo-se apenas limitado o exercício das funções de seus membros por prazo determinado de tempo. Em suma, ante o receio de vir a perder seus respectivos cargos a qualquer momento, não haveria independência funcional dos membros da $\mathrm{CGTC}^{519}$.

Finalmente, o PL dispõe que a CGTC estará vinculada à Procuradoria-Geral da Fazenda Nacional, sendo presidida pelo Procurador-Geral da Fazenda Nacional ou por Procurador da Fazenda Nacional por ele indicado (art. 46, caput). Quer dizer, assegura ao Procurador-Geral da Fazenda Nacional uma posição de destaque na sua atuação, na medida em que poderá influenciar não somente na regulamentação da transação como também na própria concessão de autorização para determinada transação no caso concreto. Com efeito, parece salutar a alteração do PL para que a Presidência da CGTC seja exercida por membro eleito entre os seus pares ${ }^{520}$.

Em suma, o PL atribui enorme margem de discricionariedade à CGTC que vão desde a regulamentação da transação até a decisão em determinado caso concreto. Além disso, a ausência de previsão de mandato fixo para seus membros não assegura efetiva independência da CGTC, quando da análise das propostas de transação. Deveras, parece recomendável a adaptação do PL de forma a melhor definir os poderes da CGTC, bem como, se possível, impor alguns limites. Ademais, vê-se com bons olhos a previsão de mandato fixo para seus membros e a previsão de eleição para a presidência do órgão.

\subsubsection{Ausência de publicidade das decisões relativas à transação}

Outra crítica bastante contundente ao PL em trâmite no Congresso Nacional consiste no fato de seus dispositivos não contemplarem ampla publicidade e transparência às decisões que venham a autorizar ou negar a realização da transação.

Apesar do PL dispor expressamente que serão observados os princípios estabelecidos no art. 37, caput, da $\mathrm{CF} / 88$, entre os quais encontra-se a publicidade, não se vislumbra qualquer previsão de publicação ou divulgação das decisões da CGTC relativas à transação (art. 47, I a III). Há, tão somente, previsão de divulgação das ementas dos termos de transação na rede mundial de computadores (art. $24, \S 3^{\circ}$ ).

\footnotetext{
519 LOPES, Simone Anacleto. Projeto de Lei Geral de Transação em Matéria Tributária: Análise das Consequências Políticas e Econômicas. In: Tributação em Revista, ano 16, n. 56, jan-jun 2010, p. 37. Disponível em: <http://www.pgfn.fazenda.gov.br/noticias/Artigo\%20Simone\%20Anacleto\%20-\%20Revista $\% 20$ Sindfisco\%20Nacional.pdf $>$. Acesso em: 11 fev. 2013.

${ }^{520}$ Em conformidade com a EMC no 2/2009 CTASP, considerando que a CGTC seria um órgão paritário, nada mais justo que se alternasse a sua Presidência entre os seus membros.
} 
Ora, a publicidade é de suma importância em todo e qualquer procedimento administrativo $^{521}$. Por meio dela, permite-se um maior controle de eventuais abusos e ilicitudes comedidos pelos órgãos administrativos. Além do mais, inibe-se o tratamento desigual a contribuintes que se encontrem na mesma situação ${ }^{522}$. A publicidade é, pois, um instrumento efetivo de controle da Administração Pública pelo próprio administrado.

Ademais, a publicidade cumpre ainda um outro papel no que tange ao procedimento de transação. É que, como afirmado pela mensagem interministerial que acompanhou o PL n ${ }^{0} 5.082 / 2009{ }^{523}$, a transação tributária implica no aperfeiçoamento e na uniformização das normas tributárias no âmbito da Administração Pública Federal. Para tanto, necessária a divulgação do conteúdo e da motivação das decisões que autorizam (ou negam) a realização da transação.

Por todas essas razões, verifica-se que não basta a divulgação das ementas dos termos de transação. Estas não contém informação quanto aos motivos, nem as condições em que se celebraram as transações. Em respeito ao princípio da publicidade, necessário dar ampla divulgação ao próprio conteúdo da transação tributária.

Nesse diapasão, parece recomendável a alteração do PL proposta pelo Deputado Vicentinho, no sentido de incluir a publicação da decisão da CGTC que autoriza a celebração da transação como requisito de validade da decisão relativa à transação (art. 47, caput). Tal alteração privilegia também a igualdade, na medida em que permite que os contribuintes verifiquem de antemão os parâmetros utilizados em determinada transação para efeitos de utilização dos mesmos nas transações que lhes digam respeito ${ }^{524}$.

No entanto, ousa-se ir um pouco mais além da proposta de alteração já formulada. Isso porque, parece conveniente que se publique não somente a decisão que autoriza a transação, como também aquela que a denega. Demais disso, é de se considerar ainda a possibilidade de divulgação dos pareceres que fundamentam a autorização para realização da transação quando esta envolver valores consideráveis $\left(\operatorname{art.} 4^{\circ}, \S 3^{\circ}\right)$.

Desta forma, vê-se também com bons olhos a proposta de Carlos Yuri Araújo Morais de formulação de um banco de dados único contendo informações acerca dos

\footnotetext{
${ }^{521}$ Excetuados, por óbvio, aqueles em que o sigilo se faça necessário.

522 JUNQUEIRA, Helena Marques. Transação Tributária. Tese (Doutorado em Direito), Faculdade de Direito da Pontifícia Universidade Católica de São Paulo, 2009, p. 173.

${ }^{523} \mathrm{Cf}$. item 8 da EM Interministerial n ${ }^{\circ} 00204 / 2008-$ MF, de 10.12 de 2008.

${ }^{524}$ Em conformidade com a EMC no $3 / 2009$ CTASP. Tal proposta de alteração já teria, inclusive, sido acatada pelo Parecer PGFN/CAT n ${ }^{\circ}$ 2254/2009, da lavra do ilustre Arnaldo Sampaio Godoy.
} 
principais precedentes em relação à transação ${ }^{525}$. Além de colaborar para unificar os critérios e requisitos da transação no âmbito da própria Administração, dá conhecimento prévio de seus resultados aos administrados, dissuadindo aqueles que não se enquadrem nos critérios previamente estabelecidos e evitando procedimentos fadados ao insucesso ${ }^{526}$.

\subsection{Considerações finais acerca do Projeto de Lei $n^{0}$ 5.082/2009}

Conforme analisado, o PL n ${ }^{0} 5.082 / 2009$, que disciplina a transação em matéria tributária em âmbito federal, insere-se no contexto das transformações ocorridas no Direito Tributário nos últimos anos. É decorrência da preocupação com a eficiência na gestão administrativo-tributária e permite uma participação mais efetiva do contribuinte no processo decisório. Ademais, aparece como uma solução viável para desobstruir o Poder Judiciário e assegurar a maior celeridade na resolução de litígios.

O PL encontra-se intrinsicamente relacionado ao PLC $n^{0} 469 / 2009$, que propõe mudanças nos arts. 156, III e 171 do CTN. Essas alterações parecem fundamentais para esclarecer algumas questões controvertidas, como é o caso do momento a partir do qual considera-se o crédito tributário efetivamente extinto. Essas mudanças não são imprescindíveis para que a transação em matéria tributária seja implementada em âmbito federal, porém, sem elas, é necessária uma reformulação completa do PL nº 5.082/2009.

Demais disso, o PL contempla também a possibilidade de transação tributária não somente em relação às multas, juros de mora e demais acessórios, como também em relação ao tributo propriamente dito nas situações em que a redução do tributo decorrer da interpretação de conceitos jurídicos indeterminados ou da identificação do fato aplicável ao caso concreto. Tal previsão, embora compatível com o ordenamento jurídico pátrio, certamente ocasionará longas discussões nas respectivas casas legislativas, vez que a questão é bastante controvertida. Caso isso venha a ocorrer, talvez seja melhor suprimir essa possibilidade até que a idéia esteja amadurecida na comunidade jurídica.

Demais disso, conforme visto no decorrer desse Capítulo, parece conveniente efetuar algumas alterações para facilitar a compreensão dos dispositivos do PL ou

\footnotetext{
${ }^{525}$ MORAIS, Carlos Yuri Araújo. Transação e arbitragem em matéria tributária: a experiência estrangeira e sua aplicabilidade ao direito brasileiro. In: SARAIVA FILHO, Oswaldo Othon de Pontes; GUIMARÃES, Vasco Branco (Org.). Transação e Arbitragem no Âmbito Tributário. Belo Horizonte: Fórum, 2008, p. 500501 .

${ }^{526}$ JUNQUEIRA, Helena Marques. Transação Tributária. Tese (Doutorado em Direito), Faculdade de Direito da Pontifícia Universidade Católica de São Paulo, 2009, p. 172 et seq.
} 
compatibilizá-los com as demais normas do ordenamento jurídico pátrio. Algumas dessas modificações já se encontram, inclusive, em Propostas de Emenda ao PL nº 5.082/2009. Tais alterações podem servir também para o aperfeiçoamento da legislação dos demais entes federativos em relação à transação em matéria tributária.

Finalmente, vale destacar que algumas questões importantes deixaram de ser abordadas no PL, restando, portanto, a dúvida: é o caso, por exemplo, da forma de repartição de receitas tributárias na hipótese de transação envolvendo tributos que, embora de competência da União, tenha uma parte do produto de sua arrecadação repassada aos Estados, Distrito Federal ou Municípios, em virtude de previsão constitucional. Não obstante tal omissão, nada impede que essa questão seja tratada em outro ato normativo, vez que esse problema não se restringe às transações tributárias, envolvendo também situações em que ocorre dação de bens em pagamento e adjudicações. 


\section{CAPÍTULO V - SÍNTESE CONCLUSIVA}

1. Um dos grandes problemas na atualidade, tanto no Brasil como em outros países mundo afora, é a demora do Poder Judiciário na resolução definitiva dos conflitos que lhes são levados. Essa demora é causada, na maioria das vezes, pelo número excessivo de demandas que tramitam na Justiça, com destaque para os processos envolvendo questões de natureza tributária.

2. As reformas para dar maior celeridade processual até então implementadas não foram suficientes para agilizar os julgamentos e desobstruir o Poder Judiciário. Além disso, a contratação de novos julgadores não parece ser uma solução adequada, tendo em vista a diversidade de problemas a ela relacionados, notadamente, seu alto custo.

3. Uma das alternativas viáveis para a resolução do problema, ao menos no que tange aos conflitos de natureza tributária, é a transação em matéria tributária. Esse instrumento, previsto há muito tempo no ordenamento jurídico brasileiro, permite não somente uma resolução célere dos conflitos, como também uma participação efetiva dos administrados no procedimento de aplicação das normas.

4. A transação em matéria tributária insere-se no contexto das diversas transformações por que passa o Direito Tributário na atualidade. Está intrinsecamente relacionada à necessidade de se conferir uma maior legitimidade social à tributação, à busca pela maior eficiência na gestão administrativo-tributária, e ao estreitamento das relações entre fisco e contribuintes.

5. Esse mecanismo de solução de controvérsias decorre também de um nova tendência do Direito Tributário contemporâneo: o "contratualismo fiscal". Tal fenômeno visa a designar não necessariamente situações em que haja um contrato propriamente dito entre fisco e contribuinte, mas em que haja uma relação menos hierarquizada e mais negocial entre as partes.

6. Vários são os exemplos no Direito Tributário dessa tendência negocial, que garante uma maior participação dos contribuintes. É o caso das consultas fiscais ou rulings, dos agréments fiscaux do Direito francês, dos acordos prévios em matéria de preços de transferência e da própria transação em matéria tributária.

7. A transação tributária e outros institutos análogos encontram-se previstos no 
ordenamento de diversos países. A título exemplificativo, a França prevê a transaction; a Itália prevê o accertamento con adesione e a conciliazione giudiziale; por fim, os Estados Unidos prevêem os closing agreements e os offers in compromise.

8. A análise do instituto da transação em matéria tributária propriamente dita, pressupõe a superação de uma questão preliminar: saber se a Administração poderia celebrar transação em assuntos envolvendo Direito Público. Conforme se analisou, a impossibilidade de transação pela Administração caracteriza-se como um falso dogma, que se encontra superado nos dias atuais, por diversas razões.

9. Em primeiro lugar, o instituto da transação coaduna-se com o princípio da legalidade. A margem de discricionariedade outorgada à Administração quando de uma atuação consensual é sem dúvida superior àquela outorgada numa atuação unilateral. Porém, essa liberdade estará sempre pautada por parâmetros estabelecidos em lei. Daí sua consonância com o princípio da legalidade.

10. De igual modo, verifica-se que transação não viola o princípio da indisponibilidade do interesse público. Deve-se sempre levar em consideração o interesse da coletividade (interesse primário) e não aquele da pessoa política (interesse secundário). Também não viola o princípio da impessoalidade seja na sua acepção de isonomia, seja na sua acepção de finalidade. Havendo administratados em situação jurídica idêntica, deve-se lhes assegurar o mesmo tratamento.

11. A transação se conforma perfeitamente com o princípio da discricionariedade. Embora goze de uma margem de valoração em sua escolha, o administrador não está livre para decidir o que bem entender. Suas escolhas deverão ser pautadas tendo como parâmetro a proporcionalidade (necessidade e adequação) e a razoabilidade (padrão de aceitabilidade), e como objetivo principal a eficiência administrativa (redução do custo e rapidez).

12. Vários são os intrumentos e normativos que permitem a transação pela Administração em matéria de Direito Público no ordenamento jurídico pátrio. É o caso, por exemplo, do termo de ajustamento de conduta nas ações civis públicas, dos compromissos de cessação de infração da ordem econômica e dos termos de compromisso em matéria ambiental. Tais exemplos corroboram para a superação do dogma da impossibilidade da Administração transacionar em matéria de Direito Público. 
13. A natureza jurídica da transação, de origem civilista, era bastante controvertida. Com o Código Civil de 2002, essa controvérsia restou superada, encontrando-se a transação entre as modalidades contratuais. Em matéria tributária, diferentemente, prevelece o entendimento de que a transação é mero ato administrativo. Trata-se, porém, de instituto em que se permite a negociação e a participação efetiva do contribuinte, em uma acepção mais ampla do denominado "contratualismo fiscal".

14. O CTN tratou da transação tributária como modalidade de extinção do crédito tributário, enumerando-a em seu art. 156 e disciplinando-a em seu art. 171. Não esclareceu, porém, o momento em que se daria tal extinção: (a) quando da celebração da transação; ou (b) quando do cumprimento do acordo e pagamento do crédito. Parece correto entender que a celebração da transação extingue o crédito tributário, porém somente em relação à parcela que as partes abriram mão ao transacionar.

15. A transação tributária possui um regime jurídico próprio no ordenamento jurídico-tributário brasileiro. Não obstante, é comum associar a transação a outros institutos do Direito Tributário pátrio: a moratória, o parcelamento, a remissão, a anistia e a denúncia espontânea. Tal confusão decorre do fato de que as leis editadas pelos entes políticos misturam os institutos, sendo por vezes difícil ao intérprete identificar qual o regime jurídico aplicável ao caso específico de que tratou a referida norma legislativa.

16. Em conformidade com a redação atual do art. 171 do CTN, a transação em matéria tributária pressupõe alguns requisitos: (a) lei autorizadora - lei específica ou genérica que permita a transação e estabeleça parâmetros para a sua realização; (b) concessões mútuas - ambas as partes devem abrir mão de, ao menos, uma parcela de suas respectivas pretensões; e (c) a terminação do litígio - deve colocar fim ao conflito de interesses existente entre as partes, seja na efera administrativa ou judicial.

17. A despeito de sua previsão expressa no CTN, controverte-se a doutrina acerca do cabimento da transação tributária no ordenamento jurídico brasileiro. Alguns dos principais argumentos utilizados são de que a transação tributária seria incompatível com: (a) o princípio da legalidade tributária; (b) a obrigatoriedade de lançamento e cobrança do crédito tributário; (c) o dispositivo que condiciona a renúncia de receitas pela Administração; e (d) o princípio da igualdade tributária.

18. A transação tributária não viola o princípio da legalidade tributária. A utilização de conceitos jurídicos indeterminados quando da elaboração das normas impõe 
ao seu aplicador certa margem de discriocionariedade quando de sua aplicação, para definir o seu conteúdo. Demais disso, a transação encontra-se prevista em lei como forma de extinção do crédito tributário, que deverá ser autorizada por outra lei (art. 171, do CTN). A transação é, pois, uma decorrência da legalidade.

19. A transação tributária não é incompatível com obrigatoriedade de lançamento (art. 142, $\S$ único, do CTN), nem de sua cobrança por atividade vinculada (art. $3^{\circ}$, do CTN). Essas atividades devem ser sempre efetuadas em conformidade com o que dispõe a lei. Um dispositivo legal específico autoriza a transação como forma de extinção do crédito tributário (art. 171, do CTN). Portanto, não há incompatibilidade, mas complementariedade dos referidos dispositivos.

20. A transação tributária também não se configura como renúncia de receitas, para fins do art. 14 da LRF. A transação não é favor fiscal concedido unilateralmente ao contribuinte, mas uma forma de se colocar fim a um litígio, que pressupõe bilateralidade. De todo modo, ainda que a transação tributária venha a ser enquadrada como renúncia de receitas, nada impede sua realização, desde que respeitadas as condições previstas no referido dispositivo.

21. Não há incompatibilidade entre a transação tributária e o princípio da igualdade tributária. Esta pressupõe o dever de diferenciação em conformidade com as particularidades de cada situação. Com efeito, a decisão individualizada proferida no procedimento de transação, em conformidade com as circunstâncias de cada caso concreto, é da essência do próprio princípio da igualdade tributária.

22. A transação tributária não necessariamente implicará em desestímulo ao pagamento voluntário de tributos. A Administração deve avaliar o risco de alguns contribuintes preferirem deixar de pagar espontaneamente seus tributos quando de seus vencimentos, para se beneficiar de eventuais reduções quando da transação tributária. Deve também sopesar a possível perda de arrecadação voluntária com os ganhos em redução de custos, celeridade, segurança jurídica, etc.

23. A discricionariedade atribuída à autoridade competente para celebrar a transação tributária não incrementa o risco de corrupção nem utilização desse instituto como instrumento político. Discricionariedade não se confunde com arbitrariedade. As decisões nos procedimentos de transação devem sempre ser motivadas. Demais disso, existem diversos mecanismos em nosso ordenamento jurídico que podem ser utilizados 
para prevenir o uso abusivo da transação.

24. A transação em matéria tributária já se encontra prevista e regulamentada na legislação de alguns Estados da federação: é o caso, por exemplo, dos Estados de Minas Gerais, Pernambuco e Santa Catarina. A despeito da necessidade de alguns reparos pontuais para aperfeiçoar a legislação dos referidos entes, verifica-se que tal iniciativa coaduna-se com o atual estágio do Direito Tributário contemporâneo, que privilegia uma maior participação da sociedade na tributação, como forma de garantir maior legitimidade social ao tributo.

25. Em âmbito federal, há quem defenda que a transação tributária já encontraria respaldo no ordenamento jurídico pátrio, ao menos em relação as causas de competência dos Juizados Especiais Federais (JEFs). A Lei $n^{0}$ 10.259/2001 previu, em seu art. 10, § único, a possibilidade de transação nos processos de sua competência, tendo sido regulamentada pelo Decreto $\mathrm{n}^{\mathrm{o}}$ 4.250/2002. Embora esses dispositivos não tratem exclusivamente da transação em âmbito tributário, a ela se aplicam.

26. Tramita na Câmara dos Deputados, o Projeto de Lei Geral de Transação em matéria tributária (PL $\mathrm{n}^{\mathrm{o}}$ 5.082/2009). Esse projeto visa a regulamentar o instituto da transação tributária no âmbito da União. Paralelamente a ele, tramita também um Projeto de Lei Complmentar (PLC n 469/2009), que introduz algumas alterações ao CTN, de forma a melhor compatibilizar a noção clássica de transação tributária às modificações trazidas pelo Projeto de Lei Geral de Transação.

27. Esse projeto constitui-se em uma alternativa viável para desobstruir o Poder Judiciário. Visa não somente a reduzir a litigiosidade e a demora na resolução de conflitos entre fisco e contribuintes, como também assegurar uma maior eficiência da Administração tributária e garantir maior segurança jurídica aos contribuintes. Resulta da mudança de paradigmas na relação fisco-contribuinte: de uma relação de confronto para uma relação de cooperação. Enfim, se aprovado, traz vantagens para ambas as partes.

28. O Projeto de Lei Geral de Transação traz um órgão técnico especializado com competência para deliberar sobre os pedidos de transação, autorizando-os ou não, sempre por meio de decisão motivada: a CGTC. Demais disso, dependendo do valor envolvido na transação, o procedimento de aprovação será mais complexo, podendo vir a ser necessário autorização do Procurador-Geral da Fazenda Nacional e até do Ministro da Fazenda. 
29. De acordo com a proposta apresentada, a transação tributária encontra alguns limites. Em princípio, somente se aplica às prestações acessórias (multa, juros, encargos, etc). Proibiu-se que a transação implique em negociação do montante do tributo. Tal vedação, entretanto, é mitigada na hipótese em que a redução do tributo decorra de interpretação de conceitos jurídicos indeterminados ou da identificação do fato num caso concreto. Demais disso, ressalvadas hipóteses específicas, vedou-se que a transação afaste atos normativos sob o fundamento de inconstitucionalidade.

30. É previsto um procedimento específico para a transação, composto por diversas fases, cada qual com efeitos próprios, destacando-se: apresentação da proposta efeito suspensivo da pretensão punitiva em relação a eventuais crimes praticados; admissão da proposta - suspensão da exibilidade do crédito e de eventuais processos, bem como interrupção da prescrição; celebração da transação - renúncia a eventuais questões deduzidas em relação ao crédito; e, cumprimento das condições pactuadas - efetiva extinção do crédito e da pretensão punitiva estatal.

31. São várias as modalidades de transação em matéria tributária constantes no projeto, a saber: transação em processo judicial, transação em insolvência civil, recuperação judical e falência; transação por recuperação tributária; e transação administrativa por adesão. Cada uma dessas modalides possuiu particularidades específicas com um regime próprio. Algumas delas possuem um marco temporal até quando podem ser realizadas a transação; outras, possuem pressupostos e requisitos próprios bastante detalhados e diferentes das demais.

32. Existem hipóteses de revogação, nulidade e revisão do termo de transação. A primeira pode ocorrer quando descumpridas as condições pactuadas, acarrentando, principalmente, a cobrança do crédito em seu valor integral e a aplicação de multa; a segunda ocorre quando a transação for realizada em inobservância às condições e requisitos formais ou materias ou outras situações mencionadas pela lei, acarretando, principalmente, a cobrança do crédito em seu valor integral; a terceira ocorre notadamente quando o termo de transação tiver se fundado, ou contrariar, interpretação do STF ou dos tribunais superiores, produzindo efeitos ex nunc.

33. O PL de transação parece coadunar-se com o ordenamento pátrio. Porém, diversos são os reparos sugeridos ao projeto, que permitiriam seu aprimoramento. É o caso, por exemplo: da previsão de recursos nas hipóteses de inadmissão e decisão 
denegatória da transação; e do esclarecimento em relação ao juízo competente para apreciar o requerimento de transação na hipótese de insolvência civil, falência ou recuperação judicial. Demais disso, parece conveniente impor limites aos poderes da CGTC, bem como fixar o prazo do mandato de seus membros. Enfim, assevera-se recomendável, ainda, a publicação não somente das ementas dos termos de transação, como também das decisões concessivas ou denegatórias da transação.

34. Finalmente, a transação em matéria tributária é não somente compatível com o ordenamento jurídico pátrio, como também desejável do ponto de vista prático. Trata-se de uma alternativa viável à situação letárgica em que se encontra o Poder Judiciário, em razão da quantidade de processos que nele tramitam e da ausência de vontade política para alterar as normas processuais atuais. Quanto à questão da eficacidade da transação tributária para resolver esse problema, somente a experiência na sua utilização poderá dizer se ela realmente terá o efeito esperado. 


\section{BIBLIOGRAFIA}

ALESSI, Renato. Diritto Amministrativo: Le Giurisdizioni Speciali Amministrative. Padova: CEDAM, 1941.

. Sistema Instituzionale del Diritto Amministrativo Italiano. Milano: Dott. Antonino Giuffre, 1953.

AMARAL JUNIOR, José Levi Mello do. Memória jurisprudencial: Ministro Aliomar Baleeiro. Brasília: Supremo Tribunal Federal, 2006.

ANDRADE, André Martins de. Transação em matéria tributária - marco legal ou marco civilizatório? In: SARAIVA FILHO, Oswaldo Othon de Pontes; GUIMARÃES, Vasco Braco (Org.). Transação e Arbitragem no Âmbito Tributário. Belo Horizonte: Fórum, 2008, p. 365-372.

ARAÚJO, Edmir Netto de. Curso de Direito Administrativo. 5. ed. São Paulo: Saraiva, 2010.

ÁVILA, Humberto. Teoria da Igualdade Tributária. 2. ed. São Paulo: Malheiros, 2009.

AVI-YONAH, Reuven S. The three goals of taxation. Disponível em: $<$ http://papers.ssrn.com/sol3/papers.cfm?abstract-id=796776>. Acesso em: 11 fev. 2013.

BALEEIRO, Aliomar. Direito Tributário Brasileiro. 12. ed. rev., atual. e compl. (atualizada por Misabel Abreu Machado Derzi). Rio de Janeiro: Forense, 2013.

BATISTA JÚNIOR, Onofre Alves. Transação no Direito Tributário, discricionariedade e interesse público. In: Revista Dialética de Direito Tributário. São Paulo: Dialética. $\mathrm{n}^{\circ} 83$, p. 116-125, ago. 2002.

. Transações administrativas. São Paulo: Quartier Latin, 2007.

BERTRAND, Henriette. Le contrôle fiscal aux États-Unis. Tese (Doutorado em Direito) Universidade de Paris I Panthéon-Sorbonne, 2004.

BIENVENU, Jean-Jacques; LAMBERT, Thierry. Droit fiscal. 4. éd. revue et mise à jour. 
Paris: PUF, 2010.

BINENBOJM, Gustavo. Da supremacia do interesse público ao dever de proporcionalidade: um paradigma para o direito administrativo. In: BINENBOJM, Gustavo. Temas de direito administrativo e constitucional. Rio de Janeiro: Renovar, 2008, p. 61-94.

BONAVIDES, Paulo. Curso de Direito Constitucional. 18. ed. São Paulo: Malheiros, 2006.

BOUVIER, Michel. Introduction au droit fiscal général et à la théorie de l'impôt. 11. éd. Paris: L.G.D.J., 2012.

. Les transformations de la légitimité de l'impôt dans la société contemporaine. In:

DERZI, Misabel Abreu Machado (Coord.). Revista Internacional de Direito Tributário, Belo Horizonte, vol. 1., n. 2., jul/dez 2004, p. 365-378.

BRASIL. Câmara dos Deputados. Projeto de Lei Geral de Transação (PL nº 5.082/2009). Distrito Federal, 2009.

BRASIL. Conselho Nacional de Justiça. Justiça em Números 2012. Disponível em: $<$ http://www.cnj.jus.br/images/pesquisasjudiciarias/Publicacoes/rel_completo_federal.pdf >. Acesso em: 17 fev. 2013.

BRASIL. Ministério da Fazenda. Trabalhos da Comissão Especial do Código Tributário Nacional. Rio de Janeiro, 1954.

BRASIL. Ministério da Fazenda. Parecer PGFN/CAT $n^{\circ}$ 2254/2009. Distrito Federal, 2009.

BRASIL. Ministério da Fazenda. Parecer PGFN CRJ nº 492/2011. Distrito Federal, 2011.

BRASIL. Tribunal Regional Federal. (3ª Região). Relatório Estatístico de Movimentação Processual do Tribunal Regional Federal da $3^{a}$ Região. Disponível em: $<$ http://www.trf3.jus.br/trf3r/index.php?id=2392>. Acesso em: 17.fev.2013.

BRESSER-PEREIRA, Luiz Carlos. Da Administração Pública burocrática à gerencial. In: 
BRESSER-PEREIRA, Luiz Carlos e SPINK, Peter. Reforma do Estado e da Administração Pública gerencial. 7. ed. Rio de Janeiro: Fundação Getúlio Vargas, 2006, p. 237-252.

BUSA, Vincenzo. Gli instituti deflativi del contenzioso nell'esperienza italiana: a experiência italiana sobre transação e conciliação em matéria tributária e demais modalidades alternativas de solução de controvérsias fiscais: In: TÔRRES, Heleno Taveira (Coord.). Direito Tributário Internacional Aplicado, São Paulo: Quartier Latin, 2008, p. 525-543, v.5.

CAMPOS, Diogo Leite de. O Sistema Tributário no Estado dos Cidadãos. Coimbra: Almedina, 2006.

CARVALHO, Rubens Miranda de. Transação Tributária, arbitragem e outras formas convencionadas de solução de lides tributárias. São Paulo: Juarez de Oliveira, 2008.

CARVALHO, Paulo de Barros. Curso de Direito Tributário. 24. ed. São Paulo: Saraiva, 2012.

CARVAlHO FILHO, José dos Santos. Manual de Direito Administrativo. 26. ed. rev. amp. e atual. São Paulo: Atlas, 2013.

CASÁS. José Osvaldo. La Transacción y la Transacción Tributaria en general en el Derecho Comparado. In: Revista Internacional de Direito Tributário. Belo Horizonte: Del Rey. v. 3, p. 73-102, jan/jun 2005.

CASSONE, Vittorio. Transação, conciliação e arbitragem no âmbito tributário: confronto entre os princípios constitucionais aplicáveis. In: SARAIVA FILHO, Oswaldo Othon de Pontes; GUIMARÃES, Vasco Braco (Org.). Transação e Arbitragem no Âmbito Tributário. Belo Horizonte: Fórum, 2008, p. 217-297.

CASTAGNÈDE, Bernard. Précis de fiscalité internationale. 3. éd. Paris: PUF, 2010.

CHEVALLIER, Jacques. Les formes actuelles de l'économie concertée. Disponível em: $<$ http://www.u-picardie.fr/labo/curapp/revues/root/1/chevallier.pdf $>$. Acesso em: 23 out. 2012. 
CHIMENTI. Ricardo Cunha. Teoria e Prática dos Juizados Especiais Cíveis Estaduais e Federais. 13. ed. rev. e atual. São Paulo: Saraiva, 2012.

CHRISPIN, Anna Carla Duarte. Transação Tributária no Paradigma do Estado Democrático de Direito Socioeconômico Cultural: o tênue limite entre a afronta ao dever fundamental de pagar tributos e a mutação da legalidade estrita rumo a juridicidade consensual dialógica. Dissertação (Mestrado em Direito), Faculdade de Direito da Pontifícia Universidade Católica de Minas Gerais, 2009.

COÊLHO, Sacha Calmon Navarro. Curso de Direito Tributário Brasileiro. 12. ed. rev. e atual. Rio de Janeiro: Forense, 2012.

COLlECTIF DALlOZ. Códe de Procédure Fiscale commenté, 19. éd. Paris: Dalloz, 2012.

COLLET, Martin. Droit Fiscal, 2. éd mise à jour. Paris: PUF, 2007.

DALLARI, Dalmo de Abreu. Elementos de Teoria Geral de Estado. 32. ed. São Paulo: Saraiva, 2013.

DACOMO, Natalia de Nardi. Direito Tributário parcipativo: transação e arbitragem administrativas da obrigação tributária. Tese (Doutorado em Direito), Faculdade de Direito da Pontifícia Universidade Católica de São Paulo, 2008.

DINIZ, Maria Helena. Curso de Direito Civil Brasileiro. Teoria das obrigações contratuais e extracontratuais. 29. ed. São Paulo: Saraiva, 2013, v.3.

DI PIETRO, Maria Sylvia Zanella. O princípio da supremacia do interesse público: sobrevivência diante dos ideais do neoliberalismo. In: DI PIETRO, Maria Sylvia Zanella et al. (Coords.). Supremacia do interesse público e outros temas relevantes do direito administrativo. São Paulo: Atlas, 2010, p. 85-102.

ELALI, André; LUCENA, Fernando. Visão Critica sobre as Teorias da Neutralidade e não Discriminação da Tributação. In: OLIVEIRA, Ricardo Mariz; SCHOUERI, Luís Eduardo; e ZILVETTI, Fernando Aurélio (Coord.). Direito Tributário Atual, São Paulo, n. 26,2011 , p. 158-168. 
ESCOLA, Hector Jorge. El Interés Público como Fundamento Del Derecho Administrativo. Buenos Aires: Depalma, 1989.

FANUCCHI, Fábio. Curso de Direito Tributário Brasileiro. 3. ed. São Paulo: Resenha Tributária, 1975, v.1.

FERRAZ, Roberto. Liberdade e Tributação: a questão do bem comum. Disponível em: $<$ http://www.hottopos.com/convenit4/ferraz.htm>. Acesso em: 09 fev. 2013.

FIGUEIREDO, Paulo Henrique. A Transação Tributária. Recife: Bagaço, Instituto do Ministério Público do Estado de Pernambuco, 2004.

FMI. Tax Law Note: Should Taxpayers Be Able to Obtain Binding Advance Rulings? Legal Departement. Disponível em: <http:www.imf.org/external/np/leg/tlaw/2004/notes/ eng/advan.htm>. Acesso em: 04 nov. 2012.

FRANÇA. Conseil d'Etat. Le contrat, mode d'action publique et de production de normes. Paris: EDCDE, n. 59, 2008. Disponível em: <http://www.ladocumentation francaise.fr/rapports-publics/084000313/index.shtml>. Acesso em: 11 nov. 2012.

GASPARINI, Diógenes. Direito Administrativo. 17. ed. Atualizada por Fabrício Motta. São Paulo: Saraiva, 2012.

GODOY, Arnaldo Sampaio de Moraes. Transação Tributária: introdução à justiça fiscal consensual. Belo Horizonte: Fórum, 2010.

- Transação e arbitragem no Direito norte-americano. In: SARAIVA FILHO, Oswaldo Othon de Pontes; GUIMARÃES, Vasco Braco (Org.). Transação e Arbitragem no Ambito Tributário. Belo Horizonte: Fórum, 2008, p. 417-440.

. A transação tributária em Pernambuco. Disponível em <http://cfc.jusbrasil .com.br/noticias/318311/a-transacao-tributaria-em-pernambuco $>$. Acesso em: $26 \mathrm{dez}$. 2012.

GOLDSCHMIDT, Fábio Brun. Arbitragem e transação tributária - verificação de compatibilidade. In: Revista Dialética de Direito Tributário. São Paulo: Dialética, $\mathrm{n}^{\mathrm{o}} 48$, p. 47-64, set. 1999. 
GORDON, Richard K. Law of Tax Administration and Procedure. In: THURONYI, Victor. Tax Law Design and Draft, Washigton D.C.: International Monetary Fund, Vol. 1, 1996, p. 95-134.

GRECO, Marco Aurélio. Do Poder à Função Tributária. In: Ferraz, Roberto (Coord.). Princípios e Limites da Tribitação 2 - Os princípios da ordem econômica e a tributação. São Paulo: Quartier Latin, 2009, p 165-176.

. Solidariedade Social e Tributação. São Paulo: Dialética, 2005.

GROSCLAUDE, Jacques; MARCHESSOU, Philippe. Procédures Fiscales. 6. éd. Paris: Dalloz, 2012.

GUEDES, Jefferson Carús. Transigibilidade de interesses públicos: prevenção e abreviação de demandas da Fazenda Pública. In: GUEDES, Jefferson Carús; SOUZA, Luciene Moessa de (Coords.). Advocacia de Estado: questões institucionais para a construção de um Estado de justiça. Belo Horizonte: Fórum, 2009, p. 243-272.

HENRIQUES, Élcio Fiori. Os Benefícios Fiscais no Direito Financeiro e orçamentário: o gasto tributário no Direito Brasileiro. São Paulo: Quartier Latin, 2010.

HIGUCHI, Hiromi; HIGUCHI, Fábio Hiroshi; e HIGUCHI, Celso Hiroyuki. Imposto de Renda das Empresas: interpretação e prática. 38. ed. São Paulo: IR publicações, 2013.

INFANTE, Gianni. L'accertamento con adesione. Tese de Láurea (Láurea em Administração, Finanças e Gestão), Faculdade de Economia da Universidade Ca'Foscari de Veneza, 2009/2010.

INSTITUTO BRASILEIRO DE DIREITO TRIBUTÁRIO. Ata da Mesa de Debates do IBDT de 10 nov. 2011. Disponível em <http://www.ibdt.com.br/material/arquivos/Atas /integra_10112011.pdf>. Acesso em 08 mar. 2013.

INSTITUTO DE PESQUISA ECONÔMICA APLICADA. Comunicado $n^{\circ} 127$, de 4 de janeiro de 2012. Disponível em: <http://www.ipea.gov.br/portal/images/stories/PDFs/ comunicado/120103_comuni cadoipea127.pdf>. Acesso em: 17 fev. 2013. 
JARDIM, Eduardo Marcial Ferreira. Outras formas de extinção da obrigação tributária. In: MARTINS, Ives Gandra da Silva (Coord.). Curso de Direito Tributário. São Paulo: Saraiva, 1982.

. Arts. 170 a 172. In: MARTINS, Ives Gandra da Silva (Coord.). Comentários ao Código Tributário Nacional. 7. ed. São Paulo: Saraiva, 2013, 2 v., p. 512.

J. ELLIS, Maarten. General Report. In: International Fiscal Association. Cahiers de droit fiscal internacional. Netherlands: Kluwer Law International. Vol. LXXXIVb: Advance Rulings. 1999, p. 21-51.

JUNQUEIRA, Helena Marques. Transação Tributária. Tese (Doutorado em Direito) Faculdade de Direito da Pontifícia Universidade Católica de São Paulo, 2009.

LAMARQUE, Jean; NÉGRIN, Olivier; AYRAULT, Ludovic. Droit Fiscal Général. 2. éd. Paris: Lexis Nexis, 2011.

LOPES, Simone Anacleto. Projeto de Lei Geral de Transação em Matéria Tributária: Análise das Consequências Políticas e Econômicas. In: Tributação em Revista, ano 16, n. 56, p. 33-40. Disponível em: <http://www.pgfn.fazenda.gov.br/noticias/Artigo\%20Simo ne\%20Anacleto\%20-\%20Revista\%20Sindfisco\%20Nacional.pdf $>$. Acesso em: 11 fev. 2012.

LOPEZ, Maria Esther Sánchez. El acuerdo de voluntades en el âmbito tributário. In: SARAIVA FILHO, Oswaldo Othon de Pontes; GUIMARÃES, Vasco Braco (Org.). Transação e Arbitragem no Âmbito Tributário. Belo Horizonte: Fórum, 2008, p. 191216.

MACHADO, Hugo de Brito. Curso de Direito Tributário. 33. ed. São Paulo: Malheiros, 2012.

. A transação no Direito Tributário. In: Revista Dialética de Direito Tributário. São Paulo: Dialética, no 75, p. 60-70, dez. 2001.

. Não-aplicação de Lei Inconstitucional pelos Órgãos de Julgamento Administrativo. In: ROCHA, Valdir de Oliveira. Grandes Questões Atuais de Direito 
Tributário. São Paulo: Dialética, 2009, p. 203-213. v. 13.

MACHADO, Hugo de Brito; MACHADO SEGUNDO, Hugo de Brito. Resposta à Consulta formulada pela Unafisco - Sindicato Nacional dos Auditores-Fiscais da Receita Federal do Brasil, em 20 de agosto de 2009. Disponível em: $<$ http://www.sindifisconacional.org.br/mod_download.phpid=L21tYWdlcy9lc3R1ZG9zL3 BhcmVjZXIvUGFyZWNlckh1Z29kZUJyaXRvTEdULnBkZnww>. Acesso em: 15 dez. 2012.

MARCHI, Eduardo C. Silveira. Guia de Metodologia Jurídica (Teses, Monografias e Artigos). Lecce: Edizioni del Grifo, 2004.

MARTINS, Ives Gandra da Silva. Transação tributária realizada nos exatos termos do art. 171 do Código Tributário Nacional - Inteligência do dispositivo - Prevalência do interesse público em acordo envolvendo prestação de serviços e fornecimento de material - Rigoroso Cumprimento da legislação complementar federal e municipal - Opinião Legal. In: SARAIVA FILHO, Oswaldo Othon de Pontes; GUIMARÃES, Vasco Branco (Org.) Transação e arbitragem no âmbito tributário. Belo Horizonte: Fórum, 2008, p. 373-382.

MARTINS FILHO, Luiz Dias; ADAMS, Luís Inácio Lucena. A transação no Código Tributário Nacional (CTN) e as novas propostas normativas de lei autorizadora. In: SARAIVA FILHO, Oswaldo Othon de Pontes; GUIMARÃES, Vasco Branco (Org.) Transação e arbitragem no âmbito tributário. Belo Horizonte: Fórum, 2008, p. 15-42.

MEIRELlES, Hely Lopes. Direito Administrativo Brasileiro. 39. ed. São Paulo: Malheiros, 2013.

MELO, José Eduardo Soares de. Curso de Direito Tributário. 10. ed. São Paulo: Dialética, 2012.

MELlO, Celso Antônio Bandeira de. Curso de direito administrativo. 30. ed. São Paulo: Malheiros, 2013.

MICHAELIS. Moderno Dicionário da Língua Portuguesa. São Paulo: Melhoramentos, 1998. 
MICHELIN, Dolizete Fátima. O anteprojeto da Lei Geral de Transação em Matéria Tributária e os princípios constitucionais da legalidade, isonomia e moralidade administrativa. In: SARAIVA FILHO, Oswaldo Othon de Pontes; GUIMARÃES, Vasco Branco (Org.). Transação e arbitragem no âmbito tributário. Belo Horizonte: Fórum, 2008, p. 331-363.

MIRANDA, Pontes de. Tratado de Direito Privado - Parte Especial, Tomo XXV. atualizado por Nélson Nery Jr., Rosa Maria de Andrade Nery. São Paulo: Revista dos Tribunais, 2012.

MONTEIRO, Washington de Barros; MALUF, Carlos Alberto Dabus; SILVA, Regina Beatriz Tavares da. Curso de Direito Civil: Direito das Obrigações - $2{ }^{a}$ parte. 40. ed. atual. São Paulo: Saraiva, 2013, v. 5.

MORAES, Alexandre de. Direito Constitucional. 29. ed. São Paulo: Atlas, 2013.

MORAES, Bernardo Ribeiro de. Compêndio de Direito Tributário. [S.1.]: Forense, 1984.

MORAIS, Carlos Yuri Araújo. Transação e arbitragem em matéria tributária: a experiência estrangeira e sua aplicabilidade ao direito brasileiro. In: SARAIVA FILHO, Oswaldo Othon de Pontes; GUIMARÃES, Vasco Branco (Org.). Transação e arbitragem no âmbito tributário. Belo Horizonte: Fórum, 2008, p. 483-503.

NABAIS, José Casalta. Contratos fiscais: reflexões acerca da sua adminissibilidade. Coimbra: Coimbra, 1994.

. O Dever Fundamental de Pagar Impostos. Coimbra: Almedina, 2009.

. Direito Fiscal. 6. ed. Lisboa: Almedina, 2010.

NOGUEIRA, Ruy Barbosa et al. Novo Código Tributário Alemão. Forense-IBDT: Rio de Janeiro - São Paulo, 1978.

NOGUEIRA, Ruy Barbosa. Curso de Direito Tributário. 13. ed. São Paulo: Saraiva, 1994.

OECD. Study into the role of tax intermediaries. Paris: OCDE, 2008. Disponível em: 
<www.oecd.org/dataoecd/28/34/ 39882938.pdf>. Acesso em: 04 nov. 2012.

OECD. Transfer Pricing Guidelines for Multinational Enterprises and Tax Administrations 2010 Edition Transfer Pricing Features of Selected Countries. [S.1.]: IBFD, 2011.

OEI, Shu-Yi. Getting More by Asking Less: Justifying and Reforming Tax Law's Offer-inCompromise Procedure. p. 1078. Disponível em: <http://papers.ssrn.com/sol3/papers.cfm ?abstract_id=1909006>. Acesso em: 10 fev. 2013.

OLIVEIRA, Gustavo Justino de. A Administração Consensual como a nova face da Administração Pública no século XXI: fundamentos dogmáticos, formas de expressão e instrumentos de ação. In: OLIVEIRA, Gustavo Justino de. Direito administrativo democrático. Belo Horizonte: Fórum, 2010, p. 211-231.

OLIVEIRA, José Jayme de Macêdo. Código Tributário Nacional: comentários, doutrina e jurisprudência. 5. ed. São Paulo: Saraiva, 2010.

OLIVEIRA, Regis Fernandes de. Responsabilidade fiscal. 2. ed. rev. São Paulo: Revista dos Tribunais, 2002.

OTERO, Paulo. Legalidade e Administração Pública: o sentido da vinculação administrativa à juridicidade. Lisboa: Almedina, 2003.

PAUlSEN, Leandro. Direito Tributário - Constituição e Código Tributário à Luz da Doutrina e da Jurisprudência. 15. ed. Porto Alegre: Livraria do Advogado, 2013.

PEREIRA, Caio Mário da Silva. Instituições de Direito Civil: Contratos, 16. ed. revista e atualizada por Regis Fichtner. Rio de Janeiro: Forense, 2012, v. 3.

PINTO, Luiz Fernando Texeira; BECHARA, Carlos Henrique Trajan. National Report: Brazil. In: International Fiscal Association. Cahiers de droit fiscal internacional. Netherlands: Kluwer Law International. Vol. LXXXIVb: Advance Rulings. 1999, p. $267-$ 276.

PRESS: Professione Economica e Sistema Sociale $n^{0}$ 43, aprile 2012. Seção People. Disponível em: <http://www.commercialisti.it/MediaContentResource.ashx?/PortalResou 
rces/Press/5a55d604-9e1c-46ea-a6bf-0c1a0b16da4b/2012\%20APRILE.pdf >. Acesso em: 10 mar. 2013.

RISCADO JÚNIOR, Paulo Roberto. Novos caminhos para a solução de litígios fiscais. In: Revista do Advogado. São Paulo: AASP, nº 94, Ano XXVII, p. 136-140, novembro de 2007.

RODRIGUES, Silvio. Direito civil: dos contratos e das declarações unilaterais da vontade. 30. ed. atual. São Paulo: Saraiva, 2004, v. 3.

ROMANO, Carlo. Advance Tax Rulings and Principles of Law: Towards an European Tax Ruling System? - Volume 4 in the Doctoral Series. IBFD, 2002.

ROSEMBUJ, Tulio. La Transacción Tributaria. Barcelona: Atelier, 2000.

ROTHMANN, Gerd Willi. O Princípio da Legalidade tributária. In: NOGUEIRA, Ruy Barbosa. Direito Tributário: Estudos de casos e Problemas. São Paulo: José Bushatsky, 1973, p. 139-180.

. Tributação, Sonegação e Livre Concorrência. In: FERRAZ, Roberto (Coord). Princípios e limites da tributação 2 - Os princípios da ordem econômica e a tributação. São Paulo: Quartier Latin, 2009, p. 331-371.

SABBAG, Eduardo de Moraes. Manual de Direito Tributário. 5. ed. atual. São Paulo: Saraiva, 2013.

SAKAKIHARA, Zuudi. Código Tributário Nacional Comentado: Doutrina $e$ Jurisprudência, artigo por artigo, inclusive ICMS e ISS. In: FREITAS, Vladimir Passos de (Coord.). São Paulo: Revista dos Tribunais, 2011.

SANTI, Eurico Marcos Diniz de. Transação e arbitragem no Direito Tributário: paranóia ou mistificação? In: FERRAZ, Roberto (Coord). Princípios e limites da tributação 2 - Os princípios da ordem econômica e a tributação. São Paulo: Quartier Latin, 2009, p. 599629.

SANTIAGO, Igor Mauler. A crise atual da coisa julagada em matéria tributária. Disponível em: $<$ http://sachacalmon.com.br/biblioteca/artigos/a-crise-atual-da-coisa- 
julgada-em-materia-tributaria>. Acesso em: 31 mar. 2013.

SARAIVA FILHO, Oswaldo Othon de Pontes. A transação e a arbitragem no direito constitucional-tributário brasileiro. In: SARAIVA FILHO, Oswaldo Othon de Pontes; GUIMARÃES, Vasco Branco (Org.). Transação e arbitragem no âmbito tributário. Belo Horizonte: Fórum, 2008, p. 43-88.

SCHOUERI, Luís Eduardo. Direito Tributário. 3. ed. São Paulo: Saraiva, 2013.

- Normas Tributárias Indutoras e Intervenção Econômica. Rio de Janeiro:

Forense, 2005.

SEIXAS FILHO, Aurélio Pitanga. Arbitragem em Direito Tributário. In: SARAIVA FILHO, Oswaldo Othon de Pontes; GUIMARÃES, Vasco Branco (Org.). Transação e arbitragem no âmbito tributário. Belo Horizonte: Fórum, 2008, p. 383-395.

SILVA, José Afonso da. Curso de direito constitucional positivo. 36. ed. rev. e atual. São Paulo: Malheiros, 2013.

SMITH, Adam. The Wealth of Nations. Introd. by KRUEGER, Alan B. New York: Bantam, 2003.

\section{SOLUÇÕES ALTERNATIVAS DE RESOLUÇÕES DE CONFLITOS: ARBITRAGEM} EM DIREITO TRIBUTÁRIO. 2011, São Paulo: Escola de Magistrados da Justiça Federal da $3^{\text {a }}$ Região (EMAG), Escola Superior da Procuradoria Geral da Fazenda Nacional em São Paulo e Associação Ibero-Americana de Arbitragem Tributária (AIBAT), 20-21 jun. 2011.

SOUSA, Rubens Gomes de. Compêndio de Legislação Tributária. 3. ed. rev. aum. e atual. Rio de Janeiro: Edições Financeiras, 1960.

TÔRRES, Heleno Taveira. Princípios de segurança jurídica e transação em matéria tributária. Os limitas da revisão administrativa dos acordos tributários. In: SARAIVA FILHO, Oswaldo Othon de Pontes; GUIMARÃES, Vasco Branco (Org.). Transação e arbitragem no âmbito tributário. Belo Horizonte: Fórum, 2008, p. 299-330.

. Transação, arbitragem e conciliação judicial como medidas alternativas 
para resolução de conflitos entre Administração e contribuintes: simplificação e eficiência administrativa. In: Revista Fórum de Direito Tributário. Belo Horizonte: Fórum, v.1, n.2, p. 91-126, mar./abr. 2003.

TORRES, Ricardo Lobo. Transação, conciliação e processo tributário administrativo equitativo. In: SARAIVA FILHO, Oswaldo Othon de Pontes; GUIMARÃES, Vasco Branco (Org.). Transação e arbitragem no âmbito tributário. Belo Horizonte: Fórum, 2008, p. 89-110.

TZIRULNIK, Luiz. Intervenção e Liquidação Extrajudicial das Instituições Financeiras. São Paulo: RT, 2000.

VANISTENDAEL, Frans. Legal Framework for Taxation. In: Tax Law Design and Drafting, volume 1, editored by Victor Thuronyi. New York: IMF, 1996.

VASCONCELOS, Frederico. Juizes no banco dos réus. São Paulo: Publifolha, 2005.

VELDE, Elly Van de. Tax “arrangements" between the tax administration and the taxpayer: the legal limits, legal qualification and legal consequences. Sumário da tese (Doutorado em Direito), Universidade da Antuérpia, Bélgica. Sumário apresentado à Associação Européia de Professores de Direito Tributário ("European Association of Tax Law Professors - EATLP”).

VIOL, Andrea Lemgruber. A Finalidade da Tributação e sua difusão na sociedade. Disponível em: <http://www.receita.fazenda.gov.br/Historico/EstTributarios/eventos/ Seminario/htm>. Acesso em: 11 fev. 2013.

WATSON, Camilla E. Tax Procedure and Tax Fraud in a nutshell. [S.L.]: Thompson, 2006.

VIII ENCONTRO NACIONAL DOS PROCURADORES DA FAZENDA NACIONAL. 2008, Alagoas: Procuradoria da Fazenda Nacional. 28-30 nov. 2008. 


\author{
ANEXO A \\ Projeto de Lei Geral de Transação (PL n $\left.{ }^{\circ} 5.082 / 2009\right)$ \\ Dispõe sobre transação tributária, nas hipóteses \\ que especifica, altera a legislação tributária e \\ dá outras providências.
}

\title{
O CONGRESSO NACIONAL decreta:
}

\section{CAPÍTULO I \\ DAS DISPOSIÇÕES GERAIS}

Art. $1^{\circ}$ Esta Lei estabelece as condições e os procedimentos que a União, por meio da Procuradoria-Geral da Fazenda Nacional e da Secretaria da Receita Federal do Brasil, e os sujeitos passivos de obrigação tributária deverão observar para a realização de transação, que importará em composição de conflitos ou terminação de litígio, para extinção do crédito tributário, nos termos dos arts. 156, inciso III, e 171 da Lei n ${ }^{\circ} 5.172$, de 25 de outubro de 1966 - Código Tributário Nacional.

Parágrafo único. Em qualquer das modalidades de transação de que trata esta Lei, a Fazenda Nacional poderá, em juízo de conveniência e oportunidade, obedecidos os dispositivos desta Lei, celebrar transação, sempre que motivadamente entender que atende ao interesse público.

Art. $2^{\circ}$ Em todos os atos e procedimentos desta Lei, serão observados os princípios do art. 37, caput, da Constituição, do art. $2^{\circ}$ da Lei $\mathrm{n}^{\circ}$ 9.784, de 29 de janeiro de 1999, e os deveres de veracidade, de lealdade, de boa-fé, de confiança, de colaboração e de celeridade.

Parágrafo único. O sujeito passivo prestará todas as informações que lhe forem solicitadas para esclarecimento dos fatos e solução efetiva dos litígios que sejam objeto de transação.

Art. $3^{\circ}$ Caso não se chegue a uma composição do conflito ou solução do litígio, os ajustes prévios, informações, dados e eventuais propostas de concessões recíprocas não serão oponíveis ou exigíveis de uma parte em relação à outra.

Parágrafo único. O disposto no caput não se aplica, quanto às informações e dados, nos casos em que:

I - a lei determine a formalização de representação fiscal para fins penais; ou

II - seja objeto de declaração ou apresentação obrigatória.

Art. $4^{\circ}$ Os procedimentos de transação previstos nesta Lei somente serão aplicados nos casos previamente disciplinados quanto aos requisitos, forma e parâmetros pela Câmara Geral de Transação e Conciliação da Fazenda Nacional - CGTC.

$\S 1^{\circ}$ Nos procedimentos de transação tributária, deverão ser observados, obrigatoriamente, o histórico fiscal, a forma de cumprimento de obrigações tributárias, a adoção de critérios de boa governança e a situação econômica do contribuinte. 
$\S 2^{\circ}$ As transações previamente aprovadas pela CGTC poderão ser formalizadas por Procuradores da Fazenda Nacional expressamente designados pelo Procurador-Geral da Fazenda Nacional, inclusive para os fins do parágrafo único do art. 10 da Lei $\mathrm{n}^{\mathrm{o}} 10.259$, de 12 de julho de 2001.

$\S 3^{\circ}$ A transação nos casos que envolvam valores superiores a $\mathrm{R} \$ 1.000 .000,00$ (um milhão de reais) dependerá de autorização expressa, mediante parecer fundamentado:

I - do Procurador-Geral da Fazenda Nacional, quando os valores envolvidos forem inferiores a $\mathrm{R} \$ 10.000 .000,00$ (dez milhões de reais); e

II - do Procurador-Geral da Fazenda Nacional, com anuência do Ministro de Estado da Fazenda, quando os valores envolvidos forem iguais ou superiores a $\mathrm{R} \$ 10.000 .000,00$ (dez milhões de reais).

$\S 4^{\circ}$ Para os casos que envolvam valores inferiores ao limite mínimo para ajuizamento de execuções fiscais pela Fazenda Nacional, a Procuradoria-Geral da Fazenda Nacional, ouvida a CGTC, fixará os critérios de transação para a hipótese de cobrança extrajudicial e procederá na forma prevista em ato do Ministro de Estado da Fazenda, observado, no que couber, o art. $6^{\circ}$ desta Lei.

Art. $5^{\circ}$ A transação não aproveita nem prejudica senão aos que nela intervierem, exceto nos casos de sucessores, responsáveis solidários, subsidiários ou substitutos tributários, no que tange aos efeitos sobre a situação jurídica relativa a cada um desses.

Art. $6^{\circ} \mathrm{A}$ transação nas modalidades previstas nesta Lei poderá dispor somente sobre multas, de mora e de oficio, juros de mora, encargo de sucumbência e demais encargos de natureza pecuniária, bem como valores oferecidos em garantia ou situações em que a interpretação da legislação relativa a obrigações tributárias seja conflituosa ou litigiosa.

$\S 1^{\circ}$ A redução de sanções de natureza pecuniária, de juros de mora e demais acréscimos pecuniários, conforme os critérios desta Lei, será admitida somente nas modalidades específicas de transação por insolvência civil, falência e recuperação judicial ou recuperação tributária, respeitados os seguintes limites:

I - até cem por cento do seu valor, no caso de exigências de multas decorrentes unicamente do descumprimento de obrigações acessórias;

II - até cinqüenta por cento das multas, de mora e de ofício; tributário;

III - até sessenta por cento dos juros de mora incidentes após a constituição do crédito

IV - até cem por cento do encargo de sucumbência e demais encargos de natureza pecuniária.

$\S 2^{\circ} \mathrm{O}$ montante de reduções de que tratam os incisos II e III do $\S 1^{\circ}$ limita-se a cinqüenta por cento do montante do crédito tributário consolidado.

$\S 3^{\circ}$ Nas modalidades de transação em processo judicial ou administrativa por adesão, poderá ser relevado o encargo legal e as verbas sucumbenciais. 
$\S 4^{\circ} \mathrm{O}$ disposto nos incisos I e II do $\S 1^{\circ}$ não se aplica às multas não passíveis de redução em decorrência de previsão expressa em lei e às multas previstas no $\S 1^{\circ}$ do art. 44 da Lei $\mathrm{n}^{\circ} 9.430$, de 27 de dezembro de 1996 , e no $\S 6^{\circ}$ do art. 80 da Lei $n^{\circ} 4.502$, de 30 de novembro de 1964.

Art. $7^{\circ} \mathrm{A}$ transação, em qualquer das suas modalidades, não poderá:

I - implicar negociação do montante do tributo devido;

II - afastar a aplicação ou deixar de observar tratado, acordo internacional, lei ou decreto, sob fundamento de inconstitucionalidade, salvo nos casos:

a) que já tenha sido declarado inconstitucional por decisão plenária definitiva do Supremo Tribunal Federal;

b) que fundamente crédito tributário objeto de:

1. dispensa legal de constituição ou de ato declaratório do Procurador-Geral da Fazenda Nacional, na forma dos arts. 18 e 19 da Lei ${ }^{\circ}$ 10.522, de 19 de julho de 2002;

2. súmula da Advocacia-Geral da União, na forma do art. 43 da Lei Complementar $n^{\circ}$ 73, de 10 de fevereiro de 1993;

3. pareceres do Advogado-Geral da União aprovados pelo Presidente da República, na forma do art. 40 da Lei Complementar n 73, de 1993;

4. pareceres do Procurador-Geral da Fazenda Nacional aprovados pelo Ministro de Estado da Fazenda;

5. solução de consulta especial emitida pelo Secretário da Receita Federal do Brasil; ou

6. súmula vinculante editada pelo Conselho Administrativo de Recursos Fiscais; e

III - dispor sobre matéria de fato ou de direito sem observar os limites do conflito ou litígio.

$\S 1^{\circ}$ Não constituem negociação do montante dos tributos as reduções que decorram do procedimento de transação, quanto à interpretação de conceitos indeterminados do direito ou à identificação e relevância do fato, aplicáveis ao caso, cujo resultado seja a redução de parte do crédito tributário.

$\S 2^{\circ}$ É competência da CGTC a admissão e análise de proposição que envolva interpretação de conceito indeterminado do direito, para efeito de conclusão de processo de transação, na forma do $\S 1^{\circ}$, ficando esse entendimento sujeito à homologação por turma especializada da Câmara Superior de Recursos Fiscais.

$\S 30 \mathrm{Na}$ composição de controvérsia jurídica, poderá a Fazenda Nacional eleger as hipóteses do art. 108 da Lei n ${ }^{0}$ 5.172, de 1966, para alcançar a solução do conflito ou litígio.

Art. $8^{\circ}$ Admitida a proposta, o prosseguimento da transação poderá ser subordinado, concomitante ou alternadamente: 

passivo;

I - à exigência de prévia assinatura de termo de ajustamento de conduta pelo sujeito

II - à substituição ou ao efeito de solidariedade do administrador inidôneo, nos termos do art.42 desta Lei.

Art. $9^{\circ}$ Sem prejuízo do disposto no art. 14, será aplicada multa sancionatória pelo descumprimento do termo de transação ou ajustamento de conduta de vinte por cento sobre o valor do débito resultante da transação.

Art. 10. Sem prejuízo das competências originárias da autoridade administrativa tributária, em quaisquer das modalidades de transação, o sujeito passivo, no exercício dos deveres a que se refere o art. $3^{\circ}$ desta Lei, facultará à Fazenda Nacional acesso e fiscalização dos livros e documentos necessários aos procedimentos referidos nesta Lei, identificadas conforme a proposta, ou às questões que forem objeto do termo de transação ou com estas relacionadas.

Art. 11. A celebração da transação, em todas as modalidades previstas nesta Lei, implicará renúncia pelo sujeito passivo ao direito sobre que se funda a ação ou recurso, administrativo ou judicial, no que tange ao mérito das questões deduzidas como objeto do termo de transação.

Parágrafo único. No caso de a pessoa jurídica fazer parte de ação coletiva, ela deverá declarar formalmente a renúncia expressa e irrevogável aos efeitos da ação, bem como qualquer alegação de direito sobre a qual referida ação se funda.

Art. 12. O termo de transação somente poderá ser discutido, administrativa ou judicialmente, quanto à sua nulidade.

$\S 1^{\circ}$ Verifica-se a nulidade do termo de transação quando:

I - não estiverem presentes condições ou requisitos, formais ou materiais, exigidos por esta Lei;

II - verse sobre:

a) as matérias vedadas pelo art. $7^{\circ}$ desta Lei; ou

b) a disposição de resultado de litígio já decidido por sentença judicial transitada em julgado, a partir da data de sua publicação ou ciência por alguma das partes;

III - houver prevaricação, concussão ou corrupção passiva na sua formação;

IV - ocorrer dolo, fraude, simulação, erro essencial quanto à pessoa ou quanto ao objeto do conflito.

$\S 2^{\circ}$ A decretação da nulidade far-se-á:

I - de ofício, pela CGTC ou órgão administrativo com competência por ela delegada, em qualquer caso, após notificação ao sujeito passivo para, querendo, manifestar-se no prazo de quinze dias, salvo se ele próprio for o requerente; ou 
II - no âmbito judicial, mediante pedido da Fazenda Nacional ou do sujeito passivo, pelo juízo competente que houver homologado a transação.

$\S 3^{\circ}$ Qualquer alegação concernente ao disposto neste artigo que, com infração aos compromissos firmados no termo de transação ou no termo de ajustamento de conduta, não se faça estritamente nos limites da demonstração de nulidade será considerada como litigância de má-fé, punível conforme os art. 17 e 18 da Lei n ${ }^{\circ}$ 5.869, de 11 de janeiro de 1973 - Código de Processo Civil, excetuados os litígios decorrentes da incorreta aplicação, por ato da Administração, dos critérios previstos no termo de transação.

$\S 4^{\circ} \mathrm{A}$ anulação do termo de transação, pelos motivos previstos nos incisos III e IV do $\S 1^{\circ}$, quando caracterizada a infração pelo sujeito passivo dos deveres a que se refere o art. $2^{\circ}$ desta Lei, impede a sua habilitação em qualquer outro procedimento de transação tributária por cinco anos, a contar da publicação do ato de decretação de nulidade a que se refere o $\S 2^{\circ}$.

$\S 5^{\circ} \mathrm{A}$ transação não se anula por erro de direito referente às questões que foram objeto da solução de controvérsias entre as partes.

$\S 6^{\circ} \mathrm{O}$ termo de transação será revisto pela autoridade competente, conforme orientação da CGTC e mediante prévia notificação ao sujeito passivo, para ciência e manifestação no prazo de quinze dias, com efeitos ex nunc quando fundado em:

I - lei ou ato normativo declarados inconstitucionais pelo Supremo Tribunal Federal; ou

II - aplicação ou interpretação da lei ou ato normativo contrário à jurisprudência definitiva dos tribunais superiores e do Supremo Tribunal Federal.

Art. 13. O descumprimento das obrigações relativas ao termo de transação:

I - interrompe a prescrição, na forma do inciso V do parágrafo único do art. 174 da Lei no 5.172, de 1966;

II - autoriza a revogação dos compromissos presentes ou futuros pactuados no termo de transação, após notificação do sujeito passivo para manifestar-se no prazo de quinze dias, com provas de suas alegações.

Parágrafo único. O disposto no inciso II não afasta a renúncia de que trata o art. 11.

Art. 14. Com a revogação ou anulação da transação, o crédito tributário será exigido no seu valor originário, com seus acréscimos legais, descontando-se o montante pago no período, prosseguindo-se na cobrança ou na execução do crédito inscrito em dívida ativa, não se aplicando as reduções previstas no art. $6^{\circ}$.

Parágrafo único. O disposto no caput implica cancelamento da certidão de que trata o inciso II do art. 20.

Art. 15. São modalidades de transação para os fins desta Lei:

I - transação em processo judicial; 
II - transação em insolvência civil, recuperação judicial e falência;

III - transação por recuperação tributária; e

IV - transação administrativa por adesão.

\section{CAPÍTULO II \\ DO REGIME GERAL DA TRANSAÇÃO}

Art. 16. O sujeito passivo somente poderá propor transação quando atendidos os requisitos previstos nesta Lei e nos seus regulamentos.

Parágrafo único. A proposta de transação poderá ser apresentada uma única vez, o que se definirá pela matéria objeto do conflito ou litígio.

Art. 17. É condição para assinatura do termo de transação que o sujeito passivo tenha cumprido todas as obrigações tributárias acessórias quando essas não sejam especificamente objeto do conflito ou litígio.

Art. 18. A proposta de transação deverá ser instruída com:

I - completa e adequada qualificação do sujeito passivo, incluindo:

a) o endereço e o número de inscrição no Cadastro Nacional de Pessoa Jurídica CNPJ de sua sede e, se houver, de suas filiais, quando estas possam aproveitar-se do resultado da transação, ou o número de inscrição no Cadastro de Pessoas Físicas - CPF;

b) o endereço postal e o endereço eletrônico aos quais deverão ser encaminhadas todas as comunicações referidas nesta Lei, ou em seus regulamentos, ao longo de todo o procedimento de transação e período de cumprimento do termo de transação, devendo, caso o endereço postal eleito para este fim não corresponda ao endereço de sua sede ou domicílio fiscal, justificar expressamente a indicação;

c) a qualificação completa dos seus titulares ou administradores;

d) a qualificação completa do seu representante legal;

e) a qualificação completa do seu representante para o procedimento de transação, se distinto do seu representante legal; e

f) independentemente da documentação que acompanhe a proposta de transação, a explicitação dos poderes conferidos pelo contrato social, estatuto social ou mandato específico ao seu representante para este procedimento, e a indicação do prazo, se houver, de validade destes mesmos poderes;

II - todos os elementos necessários à exata compreensão do conflito ou litígio, incluindo suas consequências diretas de natureza tributária ou societária;

III - informação sobre se o sujeito passivo, ou seus controladores, formularam, nos últimos cinco anos:

a) anterior proposta de transação, especificando, em caso positivo, o número do 
correspondente processo administrativo, o seu objeto específico e a conclusão do procedimento;

b) procedimento de consulta junto à Administração tributária federal sobre o mesmo objeto, no todo ou em parte, da presente proposta de transação, especificando, em caso positivo, o número do correspondente processo administrativo e a conclusão do procedimento;

c) procedimento de compensação tributária, na forma do art. 170 da Lei $n^{\circ} 5.172$, de 1966, de qualquer natureza e sob qualquer fundamento, que envolva, direta ou indiretamente, o mesmo objeto da presente proposta de transação, especificando, em caso positivo, o número do correspondente processo administrativo, o seu objeto específico e a conclusão do procedimento;

IV - atendimento aos demais requisitos materiais e formais exigidos por esta Lei ou seus regulamentos; e tributária.

V - as propostas originais de concessões para a extinção do litígio e da obrigação

Parágrafo único. Caberá ao sujeito passivo a apresentação de todas as provas dos fatos que venha a alegar na proposta de transação, incluindo pareceres, perícias e outros documentos relevantes.

Art. 19. A proposta de transação será apresentada à autoridade administrativa competente, conforme determinado por ato da CGTC, e protocolizada na correspondente unidade administrativa. protocolo.

$\S 1^{\circ}$ Considera-se recebida a proposta de transação no primeiro dia útil seguinte ao seu

$\S 2^{\circ}$ Para os fins desta Lei, considerar-se-á admitido o processamento da proposta pela autoridade administrativa, salvo ato ou manifestação em contrário, no sexagésimo dia subseqüente à data de sua recepção, na forma do $\S 1^{\circ}$, desde que dia útil.

$\S 3^{\circ} \mathrm{O}$ disposto no $\S 2^{\circ}$ não se aplica:

I - quando a autoridade administrativa receptora da proposta for incompetente para processá-la, nos termos de resolução da CGTC;

II - quando, após a recepção e antes da admissão do processamento da proposta de transação, houver sido exigida do sujeito passivo a retificação ou a complementação da sua proposta ou da documentação que a acompanhe, hipótese em que, sem prejuízo do aproveitamento dos elementos referidos no art. 18, o protocolo da emenda considerar-se-á como nova apresentação de proposta para os fins deste artigo.

$\S 4^{\circ}$ A autoridade administrativa competente pode admitir ou recusar a proposta de transação, bem como aceitar ou não as concessões apresentadas pelo sujeito passivo, em decisão cuja motivação poderá ser na forma do $\S 1^{\circ}$ do art. 50 da Lei n ${ }^{\circ}$ 9.784, de 1999.

Art. 20. A admissão do procedimento de transação pela autoridade administrativa competente, mediante despacho fundamentado, na forma dos $\S \S 2^{\circ}$ e $3^{\circ}$ do art. 19, implicará 
os seguintes efeitos:

I - suspensão do processo administrativo ou judicial no curso do procedimento de transação;

II - direito do sujeito passivo, nas matérias objeto da sua proposta e nos limites da respectiva admissão pela Fazenda Nacional, a obter certidão positiva com efeito de negativa, nos termos do art. 206 da Lei $n^{\circ} 5.172$, de 1966, desde que os eventuais impedimentos para sua emissão sejam limitados às obrigações objeto da respectiva proposta de transação;

III - autorização do sujeito passivo à Fazenda Nacional, desde a admissão do processamento da proposta até a conclusão do procedimento de transação, para solicitação, no Brasil ou no exterior, aos órgãos administrativos competentes ou a instituições financeiras, de informações e documentos necessários à verificação da situação fiscal e financeira do devedor, inclusive os submetidos a sigilo, relativos ao objeto da respectiva proposta de transação.

$\S 1^{\circ}$ Sem prejuízo da continuidade do procedimento de transação, a suspensão prevista no inciso I não abrangerá os demais processos judiciais ou administrativos em curso, que não sejam objeto do procedimento de transação.

$\S 2^{\circ} \mathrm{O}$ histórico fiscal do sujeito passivo poderá ser utilizado para a admissibilidade de garantias com vistas à preservação do direito da Fazenda Nacional.

Art. 21. As partes terão cento e oitenta dias a partir da admissão do processamento da proposta para alcançar solução para o conflito ou litígio.

$\S 1^{\circ} \mathrm{O}$ prazo previsto no caput não se suspende nem se interrompe, podendo ser prorrogado em até cento e oitenta dias, mediante decisão motivada da CGTC ou da autoridade administrativa competente.

$\S 2^{\circ}$ Escoado o prazo para celebração da transação, sem solução para o conflito ou litígio, o crédito tributário será exigido nos termos do art. 14 desta Lei.

Art. 22. No caso de revisão da proposta de transação pela autoridade administrativa competente, o sujeito passivo será imediatamente notificado, nos termos do art. 23 do Decreto $\mathrm{n}^{\circ} 70.235$, de 6 de março de 1972, por via postal, com aviso de recebimento, ou por meio eletrônico, com registro de envio, presumindo-se a recepção de qualquer destas comunicações, desde que enviada para o endereço postal ou eletrônico informado na proposta de transação, respectivamente, no décimo quinto dia subseqüente à sua postagem ou ao seu envio eletrônico.

Art. 23. A autoridade administrativa competente, designada por resolução da CGTC, examinará a proposta de transação apresentada pelo sujeito passivo e encaminhará àquela Câmara manifestação pela sua aprovação, rejeição ou modificação. de transação.

$\S 1^{\circ}$ Alcançada a solução para o conflito ou litígio, a CGTC deverá produzir o termo

$\S 2^{\circ} \mathrm{O}$ termo de transação surtirá seus efeitos desde a sua assinatura pelas partes, ou, em se tratando de transação em processo judicial, desde a sua homologação pelo juiz competente. 


\section{$\S 3^{\circ}$ A transação:}

I - é ato jurídico que se aperfeiçoa e extingue o crédito tributário após o cumprimento integral das obrigações e condições pactuadas nas cláusulas do respectivo termo;

II - não autoriza restituição ou compensação de importâncias já pagas, compensadas ou incluídas em parcelamentos cuja opção se tenha verificado anteriormente à celebração do respectivo termo;

III - autoriza, quando necessário, a substituição da certidão de dívida ativa, a qualquer tempo, sem qualquer ônus para a Fazenda Nacional; e

IV - exclui o impedimento à obtenção de certidão positiva com efeito de negativa, nos termos do art. 206 da Lei n ${ }^{0}$ 5.172, de 1966, salvo disposição contrária expressamente prevista no termo de transação, nas matérias que lhe sirvam de objeto, desde que:

a) os impedimentos para sua concessão sejam limitados às obrigações que sirvam de objeto ao termo de transação; e

b) não exista processo administrativo ou judicial em curso para a anulação ou revogação de termo de transação, nos termos dos arts. 12 e 13 desta Lei, ficando revogada certidão anteriormente emitida.

Art. 24. São requisitos obrigatórios do termo de transação:

I - forma escrita;

II - qualificação das partes transatoras;

III - referência à decisão administrativa que autoriza a celebração da transação;

IV - especificação das obrigações ajustadas;

V - fixação do valor da multa sancionatória, nos termos do art. $9^{\circ}$;

VI - cláusulas do acordo, incluindo:

a) condições econômicas consideradas;

b) responsabilidades no eventual descumprimento dos termos acordados, inclusive dos gestores, titulares, sócios e administradores no caso de pessoa jurídica;

c) renúncia expressa do sujeito passivo aos direitos ou interesses anteriores relativos ao objeto da transação, incluindo direito de promover qualquer medida contenciosa, judicial ou administrativa;

d) fixação do valor devido e o montante de renúncia do crédito tributário, se houver;

VII - data e local de sua realização; e

VIII - assinatura das partes. 
$\S 1^{\circ}$ Quando a matéria objeto do litígio entre a Fazenda Nacional e o sujeito passivo estiver presente em dois ou mais processos administrativos ou judiciais, a autoridade administrativa competente poderá autorizar a realização de procedimento de transação comum a todos, seguido de um único termo de transação.

$\S 2^{\circ} \mathrm{Na}$ assinatura do termo de transação, a Fazenda Nacional será representada pelo Procurador da Fazenda Nacional indicado pela CGTC ou pela Câmara de Transação e Conciliação - CTC de que trata o art. 48.

$\S 3^{\circ}$ Os documentos que compõem o processo de transação serão arquivados na unidade da Fazenda Pública que jurisdiciona o domicílio fiscal do contribuinte e as ementas dos termos de transação serão divulgadas na rede mundial de computadores na forma de regulamento, com preservação de informações sujeitas a segredo na forma do art. 198 da Lei $\mathrm{n}^{\circ} 5.172$, de 1966.

Art. 25. O termo de transação poderá ser condicionado à exigência de assinatura de termo de ajustamento de conduta, prévio, suplementar ou incluso no próprio termo de transação.

$\S 1^{\circ} \mathrm{O}$ sujeito passivo poderá propor ou submeter-se a termo de ajustamento de conduta perante a Fazenda Nacional, conforme plano de regularidade tributária, o qual deverá ser cumprido integralmente, sob pena de revogação do termo de transação.

$\S 2^{\circ}$ À autoridade administrativa competente caberá aprovar ou rejeitar termo de ajustamento de conduta fiscal.

$\S 3^{\circ} \mathrm{O}$ termo de ajustamento de conduta especificará as condições para o cumprimento das obrigações e demais deveres tributários assumidos, inclusive prazos ou procedimentos a serem observados em cada caso.

Art. 26. No ajustamento de conduta, o sujeito passivo poderá, de acordo com a sua proposta e com prévia anuência da autoridade administrativa competente, adotar os procedimentos de denúncia espontânea ou de imputação dos débitos inscritos em dívida ativa.

Art. 27. Aplica-se ao termo de ajustamento de conduta o disposto no art. 39, inciso I, e art. 42 desta Lei.

Art. 28. Assinado o termo de transação, na forma dos arts. 23 e 24, e havendo processo judicial em curso sobre a matéria objeto de transação, a Procuradoria-Geral da Fazenda Nacional diligenciará junto ao juiz ou tribunal onde se encontre o processo, para informar sobre a transação e requerer as providências processuais cabíveis.

$\S 1^{\circ}$ As execuções fiscais correspondentes aos débitos transigidos serão suspensas e os autos arquivados, sem baixa definitiva de distribuição, até que sejam pagos integralmente os montantes acordados.

$\S 2^{\circ}$ Nos demais casos, com a extinção da ação principal, deverão ser extintas todas as ações cautelares a ela vinculadas.

$\S 3^{\circ} \mathrm{Na}$ hipótese prevista neste artigo, o termo de transação poderá dispor sobre as verbas de sucumbência e custas judiciais. 


\section{CAPÍTULO III \\ DAS MODALIDADES ESPECÍFICAS DE TRANSAÇÃO}

Art. 29. As modalidades de transação objeto deste Capítulo observarão as disposições dos arts. $1^{\circ}$ a 25 e a sua disciplina específica.

\section{Seção I}

Da Transação em Processo Judicial

Art. 30. A transação em processo judicial terá por objeto o litígio entre as partes, como definido no pedido inicial, cuja solução, para a matéria de fato ou de direito, poderá ser alcançada inclusive mediante a consideração de elementos não constantes no processo judicial.

$\S 1^{\circ} \mathrm{A}$ transação em processo judicial somente será admitida:

I - para créditos tributários devidamente constituídos por lançamento por homologação ou por lançamento de ofício;

II - em qualquer fase do processo judicial, antes da data de publicação do despacho, positivo ou negativo, de admissibilidade de recurso especial ou extraordinário, interposto pela Fazenda Nacional ou pelo sujeito passivo; ou

III - no caso de haver execução fiscal em curso:

a) até o julgamento em primeira instância dos respectivos embargos; ou leilão.

b) não sendo opostos embargos, até a publicação da decisão que designar a data do

$\S 2^{\circ}$ Admitido o processamento da proposta de transação, nos termos do art. 19, a Procuradoria-Geral da Fazenda Nacional a levará ao conhecimento do juízo responsável pelo processo judicial para que este o suspenda nos termos e prazos definidos nesta Lei.

$\S 3^{\circ} \mathrm{A}$ transação poderá incluir matérias pertinentes àquelas deduzidas em juízo e com estas relacionadas ou conexas.

$\S 4^{\circ}$ Alcançada a transação para a solução do litígio, observar-se-á o disposto nos arts. 23 e 24 desta Lei.

$\S 5^{\circ} \mathrm{A}$ transação em processo judicial não poderá ocorrer em ações mandamentais ou em ações cautelares.

$\S 6^{\circ}$ Às transações que tenham por objeto créditos inscritos em dívida ativa, ajuizados ou não, aplicam-se, no que couber, as disposições desta Seção.

Art. 31. Ao regime de transação a que se refere o art. 30 não se aplicam os arts. 331, caput e $\S 1^{\circ}, 447$ e 448 da Lei $n^{\circ} 5.869$, de 1973.

\section{Seção II}

Da Transação no Caso de Insolvência Civil, Falência ou Recuperação Judicial 
Art. 32. Declarada a insolvência civil (Lei no 10.406, de 10 de janeiro de $2002-$ Código Civil, art. 955; Lei $\mathrm{n}^{\circ}$ 5.869, de 1973, arts. 748 e seguintes) ou decretada a falência do empresário ou da sociedade empresária, segundo os arts. 75 e 76 da Lei $\mathrm{n}^{\circ} 11.101$ de 9 de fevereiro de 2005, ou estando o sujeito passivo em processo de recuperação judicial de que trata o art. 47 da Lei $n^{\circ} 11.101$, de 2005, a Fazenda Nacional poderá propor ao juízo competente a transação tributária para os efeitos de extinção do crédito tributário de modo definitivo, nos termos de resolução da CGTC.

$\S 1^{\circ}$ A transação a que se refere o caput somente poderá ser realizada pelo juiz, quando serão apresentadas as propostas pelas partes transatoras, para garantir a satisfação dos créditos tributários, sem prejuízo da tutela aos direitos do insolvente ou do falido, da Administração da massa falida e dos titulares de créditos preferenciais, os quais deverão ser preservados no que for suficiente para a satisfação destes.

$\S 2^{\circ} \mathrm{O}$ procedimento deste artigo aplicar-se-á também aos demais casos de concurso de credores com insolvência declarada judicialmente, podendo a Fazenda Nacional, em todos eles, quando caracterizada a imprescindibilidade da medida para a recepção, total ou parcial, dos créditos tributários suportáveis pelos bens do devedor ou pela massa, admitir, por despacho fundamentado, exclusivamente no contexto das concessões recíprocas que caracterizam o procedimento de transação, o seguinte:

I - conforme o inciso I do art. 172 da Lei $\mathrm{n}^{\circ}$ 5.172, de 1966, a remissão parcial do crédito tributário, com base na situação econômica do sujeito passivo;

II - conforme alínea "d" do inciso II do art. 181 da Lei no 5.172, de 1966, anistia de penalidade tributária, condicionada ao cumprimento do termo de transação pelo sujeito passivo, no caso de este se encontrar em recuperação judicial;

III - nos termos dos arts. 155-A e 156, inciso XI, da Lei ${ }^{0}$ 5.172, de 1966, a possibilidade de parcelamento dos débitos ou de sua extinção mediante dação em pagamento.

Art. 33. O sujeito passivo que se submeter à transação por insolvência tributária, caso sobrevenha sua recuperação, com extinção da insolvência ou da falência, deverá firmar termo de ajustamento de conduta e manter, pelos cinco anos seguintes, regularidade fiscal em todos os tributos federais, sob pena de cobrança da diferença dos débitos objeto da transação, acrescidos dos encargos legais.

Art. 34. Quando se apurar que o sujeito passivo concorreu com dolo, fraude ou simulação para sua insolvência ou falência ou não se utilizou da denúncia espontânea antes da transação tributária referida nesta Seção, o respectivo termo não poderá ser concluído ou será nulo, caso já se tenha por encerrado o procedimento, sem prejuízo das consequências penais cabíveis.

\section{Seção III \\ Da Transação por Recuperação Tributária}

Art. 35. A recuperação tributária tem por objetivo viabilizar a superação de situação transitória de crise econômico-financeira do sujeito passivo, a fim de permitir a manutenção da fonte produtora, do emprego dos trabalhadores e o interesse público relativo à percepção de tributos, promovendo, assim, a preservação da empresa, sua função social e o estímulo à atividade econômica. 
Parágrafo único. A recuperação tributária não se aplica:

I - a pessoas jurídicas que podem requerer a recuperação judicial de que trata a Lei $n^{\circ}$ 11.101, de 2005;

II - às entidades de que trata o inciso II do art. $2^{\circ}$ da Lei $\mathrm{n}^{\circ} 11.101$, de 9 de fevereiro de 2005.

Art. 36. Poderá requerer a recuperação tributária o sujeito passivo que, no momento do pedido, exerça regularmente suas atividades há mais de dois anos e que atenda, por si e por seus controladores, administradores, gestores e representantes legais, no mínimo aos seguintes requisitos, cumulativamente:

I - não ser insolvente e, se o foi, que estejam declaradas extintas, por sentença transitada em julgado, as responsabilidades daí decorrentes;

II - não haver, há menos de cinco anos, concluído outra transação que, nos termos desta ou de outra lei aplicável à Fazenda Nacional, tenha implicado, direta ou indiretamente, redução do montante devido a título de tributo, juros de mora ou outros acréscimos pecuniários; e

III - não haver sido condenado, há menos de cinco anos, por fraude contra credores, fraude de execução ou por qualquer dos crimes contra a ordem tributária.

Parágrafo único. O sujeito passivo deverá desistir de forma expressa e irrevogável de impugnação ou recurso interposto, ou de ação judicial proposta, e, cumulativamente, renunciar expressamente a quaisquer alegações de direito sobre as quais se fundam os processos administrativos e ações judiciais que tratem dos débitos objeto do pedido.

Art. 37. O pedido de recuperação tributária deverá ser instruído, sem prejuízo do disposto no art. 18 , com:

I - exposição das causas da crise econômico-financeira do sujeito passivo e a demonstração da viabilidade econômica do plano de recuperação;

II - demonstrações contábeis relativas aos cinco últimos exercícios sociais e as levantadas especialmente para instruir o pedido, confeccionadas com estrita observância da legislação societária aplicável e compostas obrigatoriamente do balanço patrimonial, demonstração de resultados acumulados, bem como do resultado desde o último exercício social, e do relatório gerencial de fluxo de caixa e de sua projeção;

III - relação completa dos débitos tributários para com a Fazenda Nacional, sua classificação e valor atualizado, discriminando sua origem, os respectivos vencimentos, se estão inscritos em dívida ativa, se são objeto de execução fiscal, e a indicação dos registros contábeis de cada transação pendente;

IV - certidões dos cartórios de protestos situados na comarca do domicílio ou sede do sujeito passivo e naquelas onde possui filial;

V - relação, subscrita pelo sujeito passivo e por seu advogado, de todas as ações judiciais em que este figure como parte, inclusive as de natureza trabalhista, com a estimativa dos respectivos valores demandados e do grau de risco da condenação; 
VI - relação integral dos empregados, em que constem as respectivas funções, salários, indenizações e outras parcelas a que têm direito, com o correspondente mês de competência, e a discriminação dos valores pendentes de pagamento;

VII - laudo econômico-financeiro e de avaliação dos bens e ativos do sujeito passivo, subscrito por profissional legalmente habilitado ou empresa especializada;

VIII - relação dos bens particulares dos controladores, administradores, gestores e representantes legais do sujeito passivo, discriminando a data de sua aquisição, o seu valor atual estimado e a existência de algum ônus, encargo ou restrição de penhora ou alienação, legal ou convencional, neste último caso com a indicação da data de sua constituição e da pessoa a quem ele favorece;

IX - extratos atualizados das contas bancárias do devedor e de suas eventuais aplicações financeiras de qualquer modalidade, inclusive em fundos de investimento ou em bolsas de valores, no País ou no exterior, emitidos pelas respectivas instituições financeiras nos cinco dias úteis antecedentes à apresentação do pedido, acompanhados de declaração do sujeito passivo assumindo a responsabilidade

pelas informações relativamente a valores, à localização e à disponibilidade dos montantes, bem assim comprometendo-se informar à autoridade administrativa competente sobre qualquer movimentação ou alteração que, de modo isolado ou no conjunto dos valores, represente percentual superior a cinco por cento;

$\mathrm{X}$ - proposta de termo de ajustamento de conduta, com compromisso, por prazo não inferior a três anos, de continuidade da atividade empresarial, preservação ou aumento de empregabilidade, regularidade tributária perante a União e responsabilidade solidária dos sócios, diretores e gerentes que tenham poderes sobre a condução das atividades financeiras e possam responder por eventuais descumprimentos dos contratos sociais ou estatutos;

XI - compromisso de responsabilidade tributária, assumindo que na constituição ou na aquisição de nova empresa, no mesmo ou em outro ramo de comércio, indústria ou profissão, pelos sócios ou administradores, esta responderá integralmente pelos tributos devidos pela empresa em recuperação tributária; e

XII - autorização expressa, na forma do art. 20, inciso III, que, neste caso, não se limitará às obrigações que sirvam de objeto à respectiva proposta de transação.

$\S 1^{\circ} \mathrm{A}$ falta de indicação de algum débito vencido, inclusive aqueles que se encontrem com exigibilidade suspensa ou sob contestação em processo administrativo ou judicial, implicará nulidade da recuperação fiscal, ao que se aplicará o disposto no art. 155 da Lei $\mathrm{n}^{\circ}$ 5.172, de 1966.

$\S 2^{\circ}$ Sem prejuízo do disposto no inciso IX, no curso do procedimento de transação ou como condição do termo de transação que venha a ser pactuado, o sujeito passivo poderá ser obrigado à apresentação de contas demonstrativas mensais sob pena de cancelamento do procedimento ou do termo.

Art. 38. Para extinção do crédito tributário, o sujeito passivo poderá, de acordo com o seu plano de recuperação, utilizar, sem qualquer preferência ou ordem, parcelamentos de débitos vencidos ou dação em pagamento de bens imóveis, nas formas e condições estabelecidas em lei, nestes casos com prévia anuência da Fazenda Nacional, ou ainda 
imputação dos débitos, em qualquer caso com expresso reconhecimento do débito integral pelo sujeito passivo, para os efeitos do art. 174, parágrafo único, inciso IV, da Lei ${ }^{\circ} 5.172$, de 1966.

Parágrafo único. O plano de recuperação tributária não poderá prever prazo superior a sessenta meses para pagamento dos créditos tributários objeto do termo de transação.

Art. 39. Após admitida pela Fazenda Nacional a proposta para habilitação no procedimento de transação por recuperação tributária, e sem prejuízo dos efeitos previstos no art. 20, ao sujeito passivo será vedado:

I - desistir da proposta de recuperação tributária; ou

II - alienar ou onerar bens ou direitos de seu ativo permanente, sem prévia notificação à autoridade administrativa e desde que demonstrada a reserva de patrimônio para cumprimento do plano

de recuperação.

$\S 1^{\circ}$ A restrição disposta no inciso II, relativamente à alienação ou oneração de bens ou direitos, não se aplica quando o negócio individualmente considerado representar menos de cinco por cento do ativo permanente do sujeito passivo e quando o total das alienações desta natureza for inferior a dez por cento do ativo permanente.

$\S 2^{\circ}$ Em caso de inadimplência, o termo de recuperação tributária constituirá confissão de dívida, aplicando-se o disposto nos arts. 13 e 14 desta Lei.

Art. 40. Em todos os atos, contratos e documentos firmados no curso do procedimento de transação por recuperação tributária, desde a admissão do processamento da proposta pela Fazenda Nacional até o cumprimento de todas as obrigações pactuadas no eventual termo de transação, o sujeito passivo deverá acrescentar, após a denominação da pessoa jurídica, a expressão "em recuperação tributária".

Parágrafo único. Após a notificação do sujeito passivo sobre a admissão do processamento da sua proposta de transação, ele providenciará a comunicação desta sua condição, e informará, no prazo de trinta dias, com a documentação correspondente: divulgação;

I - ao registro público correspondente à sua natureza jurídica, para anotação e

II - às administrações tributárias federal, estadual ou distrital e municipal do domicílio da sua sede e de suas filiais;

III - ao correspondente órgão ou entidade regulador ou fiscalizador, quando se tratar de concessionário ou permissionário de serviço público de qualquer natureza;

IV - onde figure como autor ou réu em todos os processos judiciais, de qualquer natureza e em qualquer instância ou grau de jurisdição.

Art. 41. Cumpridas as obrigações no prazo determinado, a autoridade administrativa competente lavrará o termo de encerramento da recuperação tributária.

Parágrafo único. Sem prejuízo do disposto no art. $23, \S 3^{\circ}$, inciso IV, a celebração de 
contratos com a Administração Pública ou a adjudicação de licitação pública, que se efetuar com base em certidões positivas com efeito de negativas obtidas sob o regime de recuperação tributária, fica condicionada à prova da regularidade dos compromissos assumidos, emitida conforme procedimento estabelecido pela CGTC, cabendo sua imediata suspensão no caso de descumprimento comprovado, por despacho fundamentado da autoridade competente, preservado o direito de prova em contrário por parte do sujeito passivo.

Art. 42. Quando a transação por recuperação tributária for proposta por administrador inidôneo, a autoridade administrativa competente poderá solicitar seu afastamento, que será substituído na forma prevista nos atos constitutivos da empresa ou do plano de recuperação tributária, sem prejuízo de manutenção dos efeitos de solidariedade sobre o patrimônio do substituído.

Parágrafo único. Entende-se por administrador inidôneo aquele que:

I - tenha contra si denúncia aceita por juízo criminal por fraude contra credores, fraude de execução ou por qualquer dos crimes contra a ordem tributária;

II - seja reincidente em ilícitos tributários administrativos;

III - se nega a prestar informações à Fazenda Nacional, ou as presta de modo insuficiente, no curso dos procedimentos desta Lei, anterior ou posteriormente à expedição do termo de transação;

IV - descumprir obrigações decorrentes da aplicação da presente Lei;

V - atuar com dolo, simulação ou fraude;

VI - efetuar gastos manifestamente excessivos em relação a sua situação patrimonial ou a da pessoa jurídica de que seja titular, gestor, dirigente ou administrador;

VII - realizar despesas injustificáveis por sua natureza ou vulto, em relação ao capital da pessoa jurídica de que seja titular, gestor, dirigente ou administrador ou ao gênero do negócio, ao movimento das operações e a outras circunstâncias análogas;

VIII - descapitalizar injustificadamente a pessoa jurídica de que seja titular, gestor, dirigente ou administrador, ou realizar operações prejudiciais ao seu funcionamento regular;

IX - omitir créditos, sem relevante razão de direito ou amparo em decisão judicial; ou

$\mathrm{X}$ - violar condutas exigidas na legislação civil ou comercial, assim como aquelas previstas em acordos ou tratados internacionais dos quais o Brasil participe.

\section{Seção IV \\ Da Transação Administrativa por Adesão}

Art. 43. A solução de controvérsias jurídicas em matéria tributária, inclusive as de repercussão geral, poderão ser objeto de transação por adesão, mediante:

I - autorização do Ministro de Estado da Fazenda e do Advogado-Geral da União, com base na jurisprudência pacífica do Supremo Tribunal Federal ou de tribunais superiores; ou 


\section{II - previsão em lei específica.}

$\S 1^{\circ}$ A CGTC, mediante análise das solicitações de transação recebidas na forma desta Lei, poderá encaminhar ao exame do Ministro de Estado da Fazenda as hipóteses identificadas como suscetíveis de transação por adesão.

$\S 2^{\circ}$ A resolução administrativa de adesão, que disciplinará todos os requisitos e condições para que os interessados possam habilitar-se e aderir aos seus termos, terá efeitos gerais e será aplicada a todos os casos idênticos e que tempestivamente sejam habilitados, mesmo quando suficiente apenas para solução parcial de determinados litígios.

$\S 3^{\circ} \mathrm{O}$ sujeito passivo interessado deverá protocolizar seu pedido de adesão perante a Fazenda Nacional, com prova de atendimento a todos os requisitos estabelecidos pela CGTC.

Art. 44. O interessado deverá encaminhar proposta de adesão perante a unidade da Procuradoria-Geral da Fazenda Nacional ou da Secretaria da Receita Federal do Brasil do seu domicílio fiscal, com prova de atendimento a todos os requisitos estabelecidos em resolução da CGTC.

$\S 1^{\circ} \mathrm{O}$ sujeito passivo transator poderá requerer ao juiz o sobrestamento, por no máximo, noventa dias, de processo judicial em curso.

$\S 2^{\circ}$ Atendidos os pressupostos, a forma e os prazos fixados na respectiva resolução administrativa de adesão da CGTC, a autoridade administrativa formalizará o termo de transação.

Art. 45. Firmado o termo de adesão, o crédito tributário somente considerar-se-á extinto com o pagamento do débito ajustado, aplicando-se o disposto nos $\S \S 2^{\circ}$ e $3^{\circ}$ do art. 23 desta Lei.

\section{CAPÍTULO IV DAS CÂMARAS DE TRANSAÇÃO E CONCILIAÇÃO}

Art. 46. À Câmara-Geral de Transação e Conciliação - GTC, vinculada à Procuradoria- Geral da Fazenda Nacional e presidida pelo Procurador-Geral da Fazenda Nacional ou por Procurador da Fazenda Nacional por ele indicado, compete:

I - decidir sobre a progressiva implantação das modalidades de transação;

II - editar, sob a forma de resoluções, regulamentos necessários à execução desta Lei, observados, nos casos especificados, o disposto em ato do Poder Executivo;

III - editar resoluções específicas relativas à definição dos requisitos, forma e parâmetros de propostas de transação;

IV - conhecer, por meio da respectiva unidade da Procuradoria-Geral da Fazenda Nacional ou da Secretaria da Receita Federal do Brasil, de incidente de divergência entre termos de transação expedidos pela Fazenda Nacional, o qual será apresentado no prazo de trinta dias à autoridade administrativa que houver proferido a decisão supostamente divergente, e, uma vez instruído, será remetido à CGTC no prazo de quinze dias, tramitando 
sem efeito suspensivo;

V - assessorar o Procurador-Geral da Fazenda Nacional em todas as atividades relativas ao cumprimento desta Lei.

$\S 1^{\circ}$ A CGTC decidirá sobre o incidente de divergência previsto no inciso IV no prazo de trinta dias e indicará à autoridade administrativa competente que promova os ajustes no termo de transação considerado inadequado, desde que expedido há menos de cento e vinte dias, de forma a ajustá-lo ao termo de transação definido como paradigma.

$\S 2^{\circ}$ Desde a admissão do processamento da proposta até a conclusão do procedimento de transação, com a assinatura do termo, todas as questões relativas a transação serão conhecidas e decididas pela CGTC ou pela autoridade administrativa designada para este fim. transação:

Art. 47. São requisitos obrigatórios da decisão da CGTC que autoriza a celebração de

I - forma escrita e a qualificação das partes transatoras;

II - relatório, que conterá o resumo do conflito ou litígio, demonstrativo detalhado do crédito tributário consolidado objeto da transação, o montante de renúncia do crédito tributário, se houver, descrição do procedimento adotado e das concessões ou ajustes propostos;

III - decisão com todos os seus fundamentos, de fato e de direito, as suas motivações e as condições para cumprimento do acordo, incluindo:

a) as condições econômico-financeiras consideradas;

b) os compromissos para a extinção da obrigação tributária;

c) as responsabilidades das partes no eventual descumprimento dos termos acordados, inclusive dos sócios e administradores no caso de pessoa jurídica.

Parágrafo único. A motivação deverá ser clara e congruente com as circunstâncias objetivas do proponente, podendo consistir em declaração de concordância com anteriores pareceres, informações, decisões ou propostas, que, neste caso, serão considerados como parte integrante do termo de transação.

Art. 48. Ato conjunto do Procurador-Geral da Fazenda Nacional e do Secretário da Receita Federal do Brasil poderá, nos termos de resolução da CGTC, instituir Câmaras de Transação e Conciliação - CTC, presididas por Procurador da Fazenda Nacional, para realizar todos os atos necessários à aplicação desta Lei.

$\S 1^{\circ}$ A CTC competente poderá delegar a Procurador da Fazenda Nacional ou a Auditor da Receita Federal do Brasil, integrante ou não de sua composição, os seguintes atos:

I - apreciar e deliberar quanto à admissibilidade de proposta de transação:

a) nos casos relacionados no art. $7^{\circ}$; ou

b) quando verificada a ausência de quaisquer informações ou documentos indicados no art. 18, se, notificado o sujeito passivo, a deficiência não for sanada no prazo de dez dias; 
II - expedir notificações ao sujeito passivo ou efetuar requisições a órgãos ou entidades da Administração Pública, bem como a pessoas físicas ou jurídicas relacionadas ao procedimento de transação;

III - decretar a caducidade do procedimento de transação pelo advento do prazo a que se refere $o$ art. 21;

IV - rejeitar motivadamente a proposta de transação;

V - celebrar termo de transação; e

VI - praticar outros atos autorizados pela CTC.

$\S 2^{\circ}$ As CTC deverão apresentar relatórios semestrais sobre o desempenho das suas atividades, consolidados na CGTC, com publicização por meio da Procuradoria-Geral da Fazenda Nacional.

Art. 49. A CGTC e a CTC serão compostas, paritariamente, por membros designados pelo Ministro de Estado da Fazenda entre servidores públicos membros da carreira funcional de Procurador da Fazenda Nacional e Auditor-Fiscal da Receita Federal do Brasil, conforme os critérios a serem estabelecidos em ato do Poder Executivo.

$\S 1^{\circ}$ Os integrantes da CGTC e da CTC deverão possuir reputação ilibada, conhecimentos jurídicos, contábeis e econômicos, mais de dez anos de exercício funcional nas suas atuais carreiras e estar habilitados, a partir de cursos de formação específicos, nas práticas de mediação e transação.

$\S 2^{\circ}$ A permanência dos membros será limitada a quatro anos, podendo estender-se por mais quatro, uma única vez, desde que comprovada a participação em cursos de atualização e observada a avaliação dos resultados alcançados no exercício da função.

$\S 3^{\circ}$ Poderão participar das reuniões da CGTC, sem competência para deliberar e desde que atendam aos mesmos requisitos exigidos no $\S 1^{\mathrm{o}}$ :

I - dois representantes da Controladoria-Geral da União, sendo sua prévia convocação obrigatória; e

II - dois representantes dos contribuintes, escolhidos pelo Ministro de Estado da Fazenda, a partir de lista sêxtupla composta por conselheiros dos Conselhos de Contribuintes indicados por entidades de classe de categorias econômicas de nível nacional, mediante eleição direta, secreta e em turno único organizada na forma de ato da presidência do Conselho de Recursos Fiscais.

$\S 4^{\circ}$ Além dos impedimentos previstos no art. 14 da Lei $n^{\circ} 9.307$, de 23 de setembro de 1996, os membros da CGTC e das CTC deverão declarar impedimento ou suspeição sempre que:

I - houver atuado como autoridade lançadora, representante administrativo ou judicial da Fazenda Nacional no processo administrativo ou judicial no curso do qual haja sido proposto procedimento de transação ou, sob qualquer outra forma, praticado ato decisório; 
II - tratar-se de matéria que, desde a época dos fatos até a conclusão do procedimento de transação, possa ter relação, direta ou indireta, com interesses de sujeito passivo, ou de seus controladores, administradores, gestores ou representantes legais no caso de pessoa jurídica, de quem seja cônjuge, companheiro ou parente, consangüíneos ou afins, até o terceiro grau;

III - nos últimos dez anos, tenha sido empregado ou prestado serviços, a qualquer título, a sujeitos passivos ou a entidades envolvidos no procedimento de transação.

$\S 5^{\circ} \mathrm{O}$ CGTC, bem como o CTC, é órgão colegiado com atribuição de deliberar sobre a autorização e disciplinamento para celebração de transação.

$\S 6^{\circ} \mathrm{O}$ CGTC definirá em resolução normas complementares sobre cabimento, tempo e modo de celebração do termo de transação, tudo sendo aplicável, no que couber, às CTC.

$\S 7^{\circ} \mathrm{O}$ regimento interno da CGTC, aprovado por portaria do Ministro de Estado da Fazenda, estabelecerá o seu funcionamento, o número de seus membros, a presidência atribuída a Procurador da Fazenda Nacional, bem como a formação e atuação de CTC, que reproduzirá os mesmos elementos e critérios da CGTC.

Art. 50. As sessões da CGTC e CTC serão públicas, salvo decisão em contrário de ambas as Câmaras, mediante requerimento do sujeito passivo transator, quando examinar matéria sigilosa ou dados profissionais ou empresariais restritos.

Parágrafo único. O regimento interno da CGTC regulamentará o disposto no caput.

Art. 51. É defeso aos integrantes da CGTC, da CTC e aos servidores públicos, no desempenho das funções de transatores:

I - receber, a qualquer título e sob qualquer pretexto, honorários, percentagens ou custas processuais;

II - representar interesses do sujeito passivo; ou

III - receber, a qualquer título ou pretexto, auxílios ou contribuições de pessoas físicas ou de entidades públicas ou privadas, ressalvadas as exceções previstas em lei.

Art. 52. Os membros da CGTC ou da CTC e o Procurador da Fazenda Nacional ou o Auditor Fiscal da Receita Federal do Brasil, durante o exercício de competência delegada, gozarão das prerrogativas de independência funcional e inamovibilidade, e deverão agir com imparcialidade, independência, diligência, sigilo funcional e observar a todos os fundamentos, princípios e critérios desta Lei.

Parágrafo único. Os servidores referidos no caput, inclusive os referidos no $\S 3^{\circ}$ do art. 49, e aqueles servidores públicos que atuarem sob as ordens ou orientações da CGTC ou CTC serão responsabilizados criminal ou administrativamente apenas nos casos de dolo ou fraude, comprovado mediante processo administrativo disciplinar ou ação penal.

Art. 53. O Ministro de Estado da Fazenda, por solicitação do Procurador-Geral da Fazenda Nacional, poderá requisitar servidores públicos federais para atuarem provisoriamente em processo especifico de transação, na qualidade de assessores técnicos da CGTC ou das CTC. 
$\S 1^{\circ} \mathrm{O}$ Ministro de Estado da Fazenda poderá solicitar a cessão, com ônus para a União, de servidor de Estado, do Distrito Federal ou de Município para atender à finalidade prevista no caput.

$\S 2^{\circ}$ A Procuradoria-Geral da Fazenda Nacional, atendendo a solicitação da CGTC, poderá contratar empresas ou profissionais com competência técnica reconhecida para prestar assessoramento pericial nos procedimentos de transação.

\section{CAPÍTULO V \\ DAS SANÇÕES PENAIS}

Art. 54. É suspensa a pretensão punitiva do Estado, referente aos crimes previstos nos arts. $1^{\circ}$ e $2^{\circ}$ da Lei $n^{\circ} 8.137$, de 27 de dezembro de 1990, e nos arts. 168-A e 337-A do Decreto-Lei $\mathrm{n}^{\circ}$ 2.848, de 7 de dezembro de 1940 - Código Penal, a partir do período em que a pessoa jurídica relacionada com o agente dos aludidos crimes tiver protocolizado a proposta de transação. punitiva.

$\S 1^{\circ}$ A prescrição criminal não corre durante o período de suspensão da pretensão

$\S 2^{\circ}$ Extingue-se a punibilidade dos crimes referidos neste artigo quando a pessoa jurídica relacionada com o agente efetuar o pagamento integral dos débitos oriundos de tributos e contribuições sociais, inclusive acessórios.

\section{CAPÍTULO VI \\ DAS DISPOSIÇÕES GERAIS}

Art. 55. A Lei n 9.430, de 1996, passa a vigorar com as seguintes alterações:

"Art. 48. No âmbito da Secretaria da Receita Federal do Brasil, os processos administrativos de consulta serão solucionados em instância única. atribuída:

$\S 1^{\circ}$ A competência para solucionar a consulta ou declarar sua ineficácia será

I - a unidade central da Secretaria da Receita Federal do Brasil, nos casos de consultas formuladas por órgão central da Administração Pública federal, por autarquias federais, ainda que sob regime especial, fundações públicas federais ou por entidade representativa de categoria econômica ou profissional de âmbito nacional;

(NR)

"Art. 48-A. A consulta especial, para dirimir conflitos ou imprecisões quanto à interpretação da legislação tributária federal, aplicáveis às situações de interesse geral, poderá ser formulada à Secretaria Receita Federal do Brasil por:

I - representante da Administração Pública estadual, distrital ou municipal, inclusive suas autarquias, ainda que sob regime especial, e fundações;

II - confederação sindical ou entidade de classe de âmbito nacional; 
III - outros proponentes, definidos em ato do Poder Executivo.

$\S 1^{\circ}$ A formulação da consulta deverá guardar pertinência temática direta com a atividade, setor, objeto social e competência institucional dos respectivos consulentes.

$\S 2^{\circ}$ A propositura realizada pelas entidades referidas no inciso III do caput dependerá de autorização dos associados, na forma estabelecida nos seus respectivos atos constitutivos.

$\S 3^{\circ}$ A solução de consulta especial será vinculante a todos os associados da entidade referida no inciso III, uma vez confirmada a adesão da entidade consulente, ou, a critério da Administração e nos prazos estabelecidos pela Secretaria da Receita Federal do Brasil, a todos que vierem a aderir expressamente.

$\S 4^{\circ}$ A competência para solucionar a consulta especial será do órgão central da Secretaria da Receita Federal do Brasil, ouvida a Procuradoria-Geral da Fazenda Nacional.

$\S 5^{\circ}$ A solução de consulta especial será publicada no Diário Oficial da União e em sítio na rede mundial de computadores e prevalecerá sobre eventual solução de consulta específica.

$\S 6^{\circ}$ As consultas de caráter individual formalizadas nos termos do art. 48 da Lei $\mathrm{n}^{\mathrm{o}}$ 9.430, de 1996, quando tratarem de assuntos de interesse geral, serão convertidas em consultas especiais.

$\S 7^{\circ}$ A consulta especial não suspende o prazo e a forma de recolhimento do tributo antes ou depois de sua apresentação, nem para entrega de declaração de rendimentos ou cumprimento de outras obrigações acessórias." (NR)

“Art. 50-A. O Poder Executivo regulamentará a forma, os prazos, os procedimentos e os efeitos das consultas e de sua adesão, bem como os requisitos necessários para a implementação do disposto nesta Seção.” (NR)

Art. 56. O Decreto $\mathrm{n}^{\circ} 70.235$, de 1972, passa a vigorar com as seguintes alterações:

"Art.46.

Parágrafo único. Também poderão formular consulta:

I - os órgãos e entidades da Administração Pública; e

II - as entidades representativas de categorias econômicas ou profissionais.” (NR)

“Art.47.

Parágrafo único. Sem prejuízo do disposto no caput, a consulta poderá ser formulada por meio da Internet, na forma disciplinada em ato da Administração tributária." (NR)

“Art. 49-A. No caso de a consulta a que se refere o art. 48-A da Lei n ${ }^{\circ} 9.430$, de 27 de dezembro de 1996, ser eficaz, o crédito tributário relativo à matéria consultada poderá ser pago ou parcelado até o trigésimo dia subseqüente à data da ciência da decisão:

I - sem incidência de multa de mora em relação aos tributos com vencimentos 
ocorridos no período referido no art. 48;

II - com a incidência de juros e multa de mora quanto aos tributos com vencimentos ocorridos anteriormente à formulação da consulta.

$\S 1^{\circ} \mathrm{O}$ parcelamento de que trata o caput poderá ser solicitado independentemente de o sujeito passivo já possuir outros parcelamentos para com a Fazenda Nacional.

$\S 2^{\circ} \mathrm{O}$ disposto neste artigo aplica-se aos associados ou filiados de entidade representativa de categoria econômica ou profissional identificados na consulta." (NR)

"Art.53.

Parágrafo único. Na hipótese do parágrafo único do art. 47, a Administração tributária poderá atribuir o preparo e o exame de admissibilidade do recurso à unidade da Administração tributária diversa da prevista no caput." (NR)

Art. 57. A Lei $\mathrm{n}^{\mathrm{o}} 10.522$, de 2002, passa a vigorar com as seguintes alterações:

"Art.10.

$\S 1^{\circ}$ Ao parcelamento referido no art. 49-A do Decreto $\mathrm{n}^{\circ} 70.235$, de 6 de março de 1972, aplicam-se, no que couber, as regras fixadas nesta Lei." (NR)

Art. 58. O inciso VI do art. 965 da Lei $\mathrm{n}^{\circ}$ 10.406, de 2002 - Código Civil, passa a vigorar com a seguinte redação:

"VI - o crédito pelos tributos devidos à Fazenda Pública;" (NR)

\section{CAPÍTULO VII \\ DAS DISPOSIÇÕES FINAIS}

Art. 59. Toda e qualquer transação em matéria tributária somente poderá ser efetivada por meio das modalidades prevista nesta Lei.

Art. 60. O disposto nesta Lei aplica-se, no que couber, aos créditos não-tributários inscritos em dívida ativa da União.

Parágrafo único. Após a admissão do processamento da proposta de transação, na forma dos $\S \S 2^{\circ}$ e $3^{\circ}$ do art. 19, o órgão ou a entidade originalmente responsável pela constituição ou pela Administração do crédito, quando não pertencente à estrutura do Ministério da Fazenda, será consultado pela CGTC ou pela CTC competente, conforme o caso, para que, no prazo de trinta dias, manifeste a sua objeção à seqüência do procedimento ou a aspectos específicos da proposta formulada pelo sujeito passivo.

Art. 61. Esta Lei não se aplica ao regime previsto na Lei Complementar $\mathrm{n}^{\mathrm{o}}$ 123, de 14 de dezembro de 2006.

Art. 62. Esta Lei entrará em vigor um ano após a data de sua publicação.

Art. 63. Revoga-se o art. 49 do Decreto $\mathrm{n}^{\mathrm{o}}$ 70.235, de 6 de março de 1972. 
EM Interministerial $n^{\circ} 00204 / 2008$ - MF

Brasília, 10 de dezembro de 2008.

Excelentíssimo Senhor Presidente da República,

1. Submetemos à elevada apreciação de Vossa Excelência a minuta do Anteprojeto da Lei Geral de Transação em Matéria Tributária, resultado das discussões com vários setores da sociedade, da Administração tributária e do Poder Judiciário.

2. O anteprojeto vem no bojo de um conjunto de medidas destinadas à modernização da Administração Fiscal, para tornar a sua atuação mais transparente, célere, desburocratizada e eficiente. As outras medidas que caminham no mesmo sentido consistem na edição de outras duas leis ordinárias (uma referente aos mecanismos de cobrança dos créditos inscritos na dívida ativa da União e a outra, à execução fiscal administrativa) e uma lei complementar (alteração do Código Tributário Nacional), essa última indissociável do presente anteprojeto, visto que alguns de seus efeitos dependem das alterações naquela lei propostas (como os que tratam da interrupção da prescrição, das causas de suspensão da exigibilidade do crédito tributário e da prova da regularidade fiscal).

3. O escopo do anteprojeto é o de constituir nova relação entre a Administração tributária e os contribuintes, possibilitando que as duas partes, mediante entendimento direto, alcancem uma aplicação mais homogênea da legislação tributária. O presente Anteprojeto de Lei parte dos permissivos já existentes nos artigos 156, incisos III e IV, 171 e 172 do Código Tributário Nacional (Lei $\mathrm{n}^{0}$ 5172, de 1966, entre nós vigorando com força de Lei Complementar). Assim é que a transação em matéria tributária está prevista no CTN, mas até a presente data não foi regulamentada.

4. Hoje se estima, no âmbito da Procuradoria-Geral da Fazenda Nacional, que a fase administrativa do processo tributário tenha, em média, uma duração de 04 anos para ser concluída e a fasejudicial, 12 anos. Esse fato, somado à ineficácia da execução fisscal dos créditos tributários, explica, em boa medida, o fato de que menos de $1 \%$ do estoque da dívida ativa da União de $\mathrm{R} \$ 400$ bilhões de reais ingressa nos cofres públicos a cada ano por essa via, sendo que o percentual do ingresso não ultrapassa a dois vírgula cinco por cento do estoque ( $\mathrm{R} \$$ 9,6 bilhões de reais de arrecadação em 2006), mesmo com as medidas de parcelamento adotadas (REFIS, PAES e PAEX) e com a incorporação dos depósitos judiciais. O estoque da dívida ativa da União, incluída a da Previdência Social, já alcança a cifra de R\$ 600 bilhões de reais e, uma vez incorporado o que ainda está em litígio administrativo, chegase à impressionante cifra de $\mathrm{R} \$ 900$ bilhões de reais. Esse número representa 1,5 vezes a arrecadação da União de 2006 e, apenas no âmbito da arrecadação federal, cerca de metade do PIB do país.

5. Vale notar, ainda, que a morosidade na resolução dos litígios tributários produz graves distorções nos mercados, sendo profundamente danoso para a livre concorrência. As sociedades empresariais que honram pontualmente suas obrigações fiscais vêem-se, muitas vezes, na contingência de concorrer com outras que protraem no tempo o pagamento de tributos por meio de discussões administrativas e judiciais meramente protelatórias.

6. A concretização das medidas previstas no Anteprojeto em comento aumentará a eficácia do sistema arrecadatório nacional. Com efeito, os conflitos tributários serão resolvidos em menor prazo, no máximo em um ano, o que tornará, para o contribuinte, mais 
vantajosa a transação do que a aposta em longas discussões judiciais.

7. Assim sendo, a transação traduzir-se-á em uma maior participação do contribuinte na Administração tributária, o que implica uma significativa mudança de paradigmas na relação Estado / contribuinte. Para a Fazenda Nacional, a vantagem será a realização imediata de créditos tributários, sem os altos custos do processo judicial, o que, sem dúvida, vem ao encontro do interesse público. Ademais, a adoção desses meios alternativos, a médio prazo, desafogará as instâncias administrativas de julgamento e o Poder Judiciário.

8. Também é certo que a transação tributária importará em maior segurança jurídica para o contribuinte, bem como no aperfeiçoamento e uniformização da interpretação das normas tributárias no âmbito da Administração Fiscal. De fato, o Anteprojeto prevê o julgamento por um órgão técnico especializado, único apto a lidar com a grande complexidade da legislação tributária pátria, garantindo, assim, a resolução eficiente, segura e justa dos litígios tributários. Além disso, terá efeitos significativos para aliviar o Poder Judiciário e as instâncias administrativas de julgamento, diminuir a litigiosidade na aplicação da legislação tributária, permitir a maior eficiência na arrecadação dos tributos e o aumento do cumprimento voluntário das obrigações tributárias, com a eliminação dos desperdícios públicos decorrentes da sistemática em vigor.

9. Importante ressaltar que em vários paises, como a Alemanha, França, Reino Unido, Itália, Estados Unidos e México adotam o instituto, que tem-se mostrado de grande valia para a efetiva recuperação dos créditos e para a própria realização da justiça fiscal. $\mathrm{Na}$ atual conjuntura, a falta de sua regulamentação tem sido sentida pelos operadores do Direito Tributário no Brasil.

10. O anteprojeto prevê quatro modalidades de transação - a transação em processo judicial; a transação em insolvência civil, recuperação judicial e falência; a transação por recuperação tributária e a transação administrativa por adesão, além de prever que o termo de transação poderá ser condicionado à exigência de assinatura de termo de ajustamento de conduta, prévio, suplementar ou incluso no próprio termo de transação, que especificará as condições para o cumprimento das obrigações e demais deveres tributários assumidos, inclusive prazos ou procedimentos a serem observados.

11. Caberá à Câmara-Geral de Transação e Conciliação - CGTC, vinculada à Procuradoria-Geral da Fazenda Nacional e composta paritariamente por procuradores da Fazenda Nacional e por auditores-fiscais da Receita Federal do Brasil, disciplinar, analisar e deliberar sobre os pedidos de transação.

12. O anteprojeto estabelece os seguintes requisitos gerais para a transação:

a) ocorrerá somente nos casos previamente disciplinados e autorizados pela CâmaraGeral de Transação e Conciliação da Fazenda Nacional - CGTC (art. $4^{\circ}$ );

b) nos casos de valores superiores a um milhão dependerá da prévia autorização do Procurador-Geral da Fazenda Nacional, e superiores a dez milhões, do Ministro da Fazenda $\left(\S 3^{\circ}\right.$ do art. $\left.4^{\circ}\right)$;

c) para valores inferiores ao limite mínimo de execução fiscal, a PGFN, ouvida a CGTC, fixará os critérios de transação $\left(\S 4^{\circ}\right.$ do art. $\left.4^{\circ}\right)$;

d) a transação não aproveitará nem prejudicará senão aos que nela intervirem $\left(\operatorname{art} .5^{\circ}\right)$;

e) a transação somente poderá dispor sobre multas, juros de mora, encargos de sucumbência e de natureza pecuniária nos seguintes limites $\left(\operatorname{art.} 6^{\circ}\right)$ :

1. Até cem por cento no casos de exigências de multas do descumprimento de 
obrigações acessórias;

2. Até cinqüenta por cento das sanções pecuniárias;

3. Até sessenta por cento dos juros de moras; e

4. Até cem por cento dos demais encargos pecuniários como a sucumbência.

f) a transação não poderá resultar na negociação do montante dos tributos devidos, nem dispor sobre matéria de inconstitucionalidade (art. $7^{\circ}$ );

g) a transação poderá ser subordinada à assinatura de termos de ajustamento deconduta e à substituição e à solidariedade do administrador inidôneo (art. $8^{\circ}$ );

h) o sujeito passivo facultará à Fazenda Nacional o acesso e a fiscalização dos documentos necessários ao procedimento de transação (art. 10);

i) a celebração da transação implicará renúncia, pelo sujeito passivo ao direito sobre que se funda a ação ou recurso administrativo ou judicial (art. 11);

j) o termo de transação somente poderá ser discutido, administrativa ou judicialmente quanto à sua nulidade (art. 12);

k) a transação não se anulará por erro de direito ( $\left(5^{\circ}\right.$ do art. 12$)$;

1) o termo de transação poderá ser revisto pela Fazenda Pública, com efeitos ex nunc, quando fundando em lei ou ato normativo declarados inconstitucionais pelo STF ou aplicação ou interpretação da lei ou ato normativo contrário à jurisprudência definitiva dos tribunais superiores e do Supremo Tribunal Federal $\left(\S 6^{\circ}\right.$ do art. 12$)$;

m) o descumprimento das obrigações firmadas na transação (art. 13), autoriza a interrupção da prescrição, a revogação dos compromissos presentes e futuros após manifestação do sujeito passivo no prazo de 15 dias, a execução da dívida integral constante do termo de transação e a cobrança integral do crédito tributário devido na origem, atualizado e acrescido de juros de mora, descontando-se o valor arrecadado no período;

n) o sujeito passivo poderá propor ou submeter-se a termo de ajustamento de conduta perante a Fazenda Nacional, conforme plano de regularidade tributária, que deverá ser cumprido integralmente, caso admitido, sob pena de revogação do termo da transação.

13. O anteprojeto, ainda, introduz a consulta especial, para dirimir conflitos ou imprecisões quanto a interpretação da legislação tributária, aplicáveis às situações de interesse geral.

14. Estas são, Excelentíssimo Senhor Presidente da República, as razões que fundamentam a proposta que ora submetemos à elevada consideração de Vossa Excelência.

Respeitosamente,

Assinado eletronicamente por: Guido Mantega, Jose Antonio Dias Toffoli 